André Luiz Cavazzani

Cléber Araújo Cabral

\title{
ZOOTRÓPIO
}

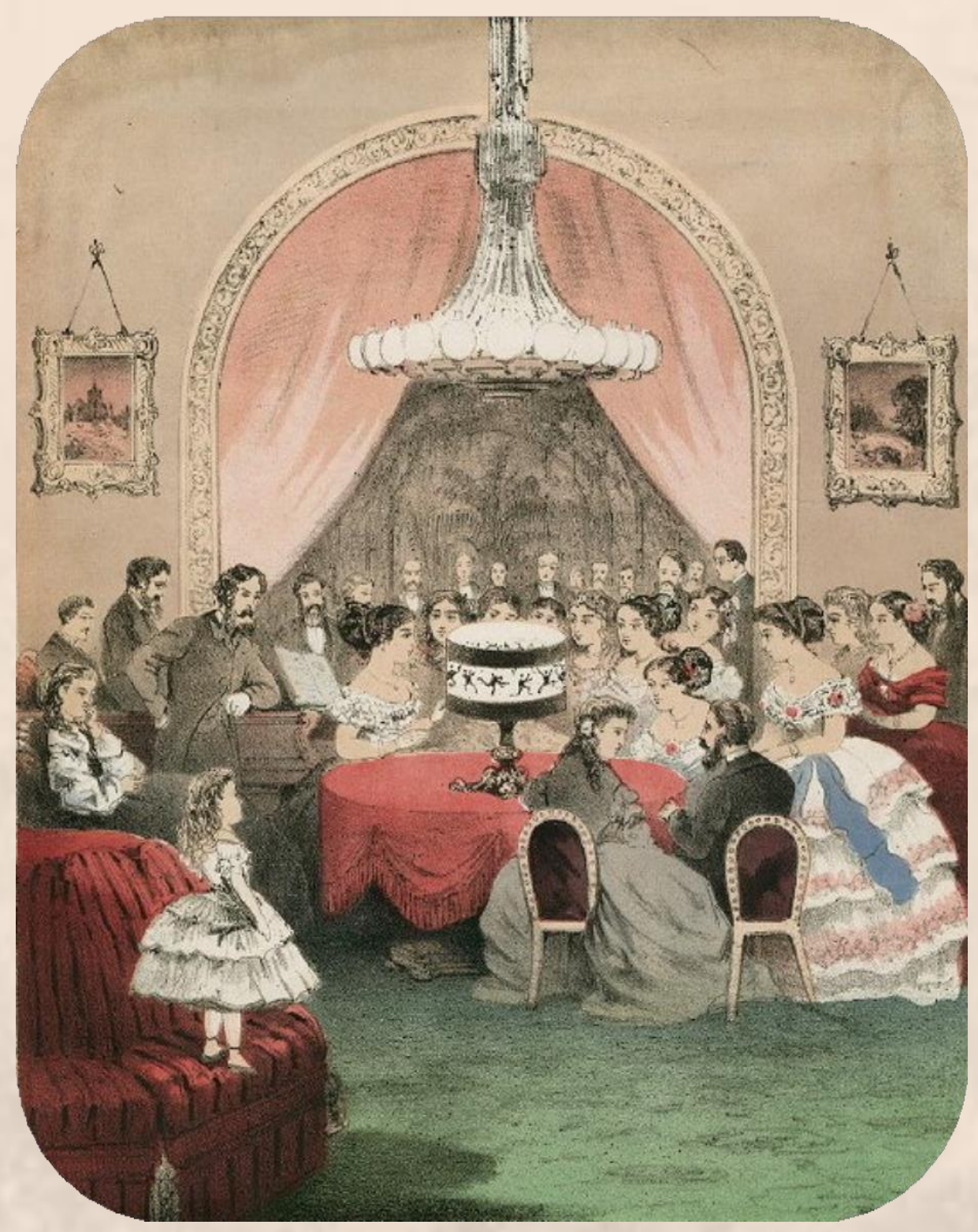

\section{LEITURAS DE LINGUAGENS, TEMPOS E SOCIEDADES}

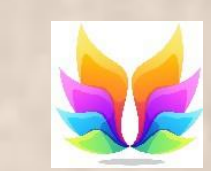

Editora Dialética e Realidade Curitiba

2021 
Os livros do selo Dialética e Realidade apresentam resultados de pesquisas desenvolvidas por professores e pesquisadores em formato eletrônico com licenciamento ( $C C$ BY $+N C)$. A proposta de tratamento dialético busca estabelecer a verdade por meio de argumentos que esclareçam aspectos de interesse para a comunidade acadêmica e para a sociedade de forma geral.

\begin{tabular}{|ll}
\hline \multicolumn{2}{l}{ Dados Comerciais } \\
\hline Rua & Alberto Rutz 491 - Casa 4 \\
Cidade & Curitiba \\
Bairro & Portão \\
CEP & 81320280 \\
Site & http://dialeticaerealidade.com \\
E-mail & dialeticaerealidade@gmail.com
\end{tabular}

Editora chefe Prof. ${ }^{a}$ Dr. ${ }^{a}$ Dinamara Pereira Machado

Responsável técnico Prof. Dr. Antonio Siemsen Munhoz

Aprendiz técnica Fabíola Ribeiro Vieira

Conselho Editorial Nacional

Prof. Dr. Adriano Souza Lima

Prof. Dr. André Luiz Moscaleski Cavazzani

Prof. Dr. Antonio Siemsen Munhoz

Prof. ${ }^{a} \quad$ Dr. ${ }^{a}$ Andréia Furtado

Prof. Me. Armando Kolbe Júnior

Prof. Dr. Cícero Manoel Bezerra

Prof. ${ }^{a} \quad$ Dr. ${ }^{a}$ Deisily de Quadros

Prof. ${ }^{a} \quad$ Dr. ${ }^{a}$ Dinamara Pereira Machado

Prof. Me. Edvaldo Luiz Rando Junior

Prof. ${ }^{a} \quad$ Dr. ${ }^{a}$ Flávia Brito Dias

Prof. Dr. Guilherme Augusto Pianezzer

Prof. ${ }^{a} \quad$ Dr. ${ }^{a}$ Gisele do Rocio Cordeiro

Prof. ${ }^{a} \quad$ Dr. ${ }^{a}$ Katiuscia Mello Figuerôa

Prof. Dr. Luis Fernando Lopes 
Prof. ${ }^{a}$. Dr. ${ }^{a}$ Leociléa Aparecida Vieira

Prof. Dr. Marcos Ruiz da Silva

Prof. ${ }^{a} \quad$ Esp. Maria Teresa Xavier Cordeiro

Prof. Dr. ${ }^{a}$ Marilene Garcia

Prof. ${ }^{a} \quad$ Dr. ${ }^{a}$ Márcia Regina Mocelin

Prof. ${ }^{a} \quad$ Dr. ${ }^{a}$ Naura Garcia Carapeto Ferreira

Prof. Me. Paulo Martinelli

Prof. Dr. Rafael Pereira Dubiela

Prof. ${ }^{a} \quad$ Dr. ${ }^{a}$ Roberta Ravaglio Gagno

Prof. ${ }^{a} \quad$ Dr. ${ }^{a}$ Renata Adriana Garbossa Silva

Prof. ${ }^{a} \quad$ Me Renata Burgo Fedato

Prof. ${ }^{a} \quad$ Dr. ${ }^{a}$ Tatiane Calve

Prof. ${ }^{a} \quad$ Me. Thiana Maria Becker

\section{Conselho Editorial Internacional}

Prof. Dr. Santiago Castillo Arredondo

Prof. ${ }^{a} \quad$ Dr. ${ }^{a}$ Maria Esther Martinez Quinteiro

O projeto publicação acadêmica reúne um grupo de pesquisadores especializados e independentes provenientes de diferentes IES em nível global. Ele está desenhado com a integração de diversas áreas do conhecimento. Seu objetivo é a abertura de um canal de comunicação utilizado para divulgação de estudos e pesquisas acadêmicas. A participação não resulta em remuneração financeira de nenhuma espécie. Os únicos recursos financeiros envolvidos são aqueles devidos ao registro do ISBN, do código de barras e da ficha catalográfica. Custos administrativos poderãoser rateados entre os participantes. Os textos publicados são de total responsabilidade de seus autores.

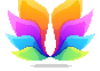

Editora Dialética e Realidade 
Esta obra está sendo entregue aos leitores na modalidade creative commons licenciada de acordo com os seguintes termos cc by+nc. Esta indicação permite que a obra seja utilizada de forma livre, referenciando o autor e não utilizando o material com finalidades comerciais.

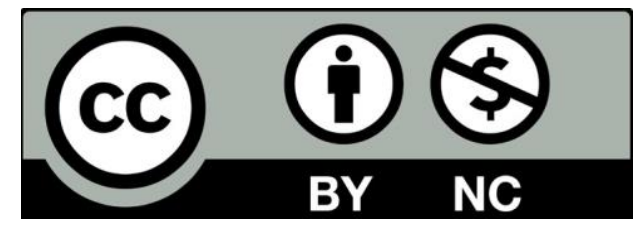

Dados Internacionais de Catalogação na Publicação (CIP) (Câmara Brasileira do Livro, SP, Brasil)

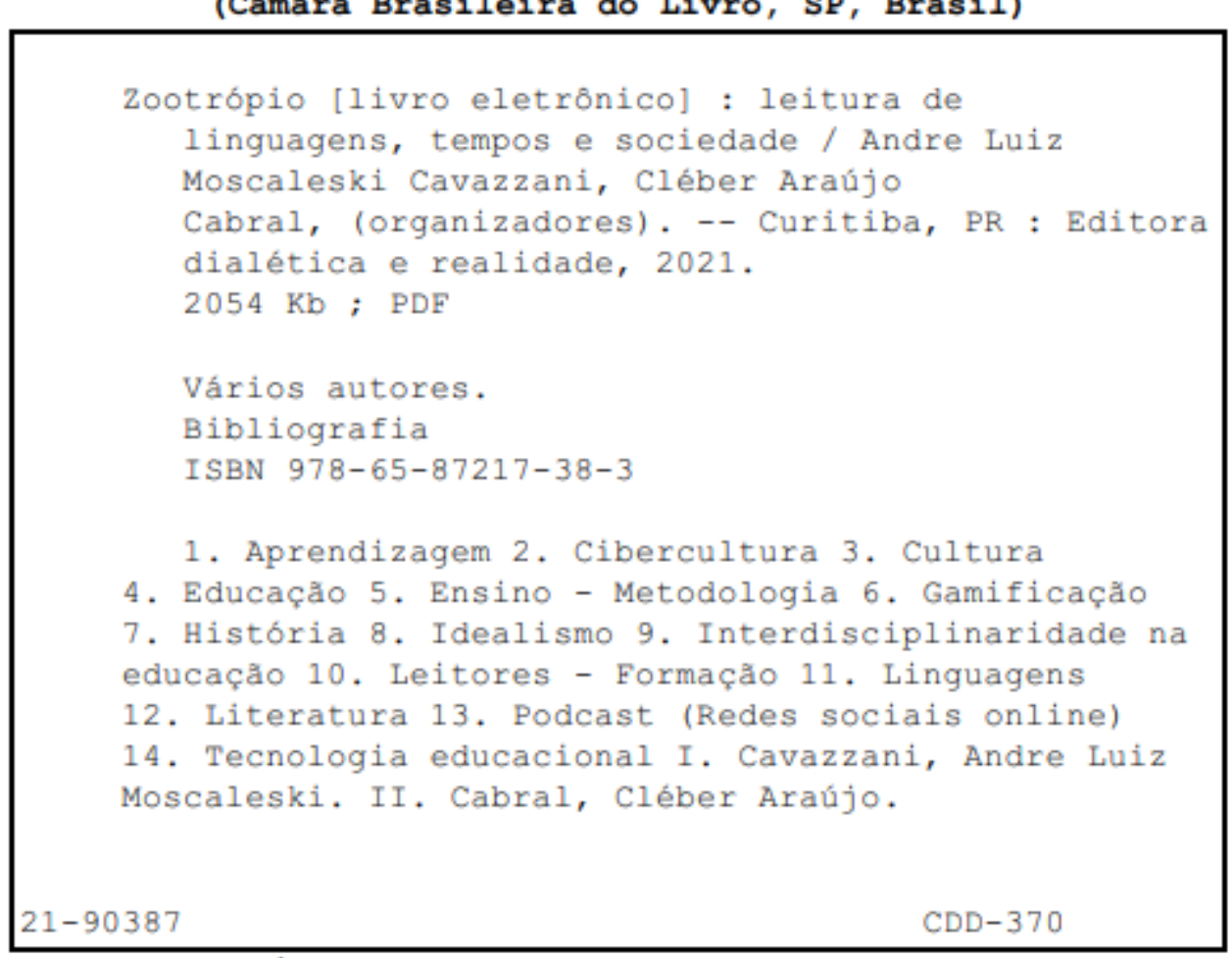

Índices para catálogo sistemático:

1. Aprendizagem : Interdisciplinaridade : Educaçăo 370

Eliete Marques da Silva - Bibliotecária - CRB-8/9380

CAVAZZANI $_{\bar{\gamma}}$ André Luiz Moscaleski; CABRAL, Araújo Cleber(Orgs). Zootrópio: leituras de linguagens, tempos e sociedades. Curitiba: Editora Dialética e Realidade, 2021. 
Revisor: Josué Borges de Araújo Godinho

A responsabilidade pela concordância dos autores com a publicação dos artigos foi assumida pelos organizadores.

Fonte capa: acervo da the Bill Douglas Cinema Museum, U niversity of Exeter, Inglaterra. 


\section{ZOOTRÓPIO: LEITURAS DE LINGUAGENS, TEMPOS E SOCIEDADES}

Editora Dialética e Realidade

Curitiba

2021 


\section{ANDRÉ LUIZ MOSCALESKI CAVAZZANI}

\section{CLEBER ARAÚJO CABRAL \\ (Orgs.)}

\section{ZOOTRÓPIO: LEITURAS DE LINGUAGENS,TEMPOS E SOCIEDADES}

Editora Dialé Dialética e Realidade

Curitiba 


\section{SUMÁRIO}

APRESENTAÇÃO 9

ANDRÉ LUIZ MOSCALESKI CAVAZZANI CLEBER ARAÚJO CABRAL UMA ESPÉCIE EM VIAGEM: UMA REFLEXÃO SOBRE TRANSUMÂNCIA, DESENVOLVIMENTO REGIONAL E ENSINO SUPERIOR

ANDRÉ LUIZ MOSCALESKI CAVAZZANI RENATA ADRIANA GARBOSSA ROMANTISMO E IDEALISMO ALEMÃES: FUNDAMENTOS ARTÍSTICOS, HISTÓRICOS E FILOSÓFICOS DO SÉCULO XVIII .24

CAROLINA MEIRE DE FARIA DESCOMPASSOS COMBINADOS: ASPECTOS DA FICÇÃO DE MURILO RUBIÃO. 61

CLEBER ARAÚJO CABRAL UM ESTUDO INTERGERACIONAL SOBRE O ACESSO À INFORMAÇÃO E FAKE NEWS: IMPLICAÇÕES PARA A LEITURA DE MUNDO

CRISTIANE DALL'AGNOL DA SILVA BENVENUTTI ELIZANDRA JACKIW ENSINO DE PRODUÇÃO TEXTUAL: RECONFIGURAÇÃO DO PAPEL DO PROFESSOR E DA ESCOLA ................................................... 108

DANIELLE FRACARO DA CRUZ PROGRAMA "CONTA PRA MIM" E A (NÃO) FORMAÇÃO DE LEITORES ....124 DEISILY DE QUADROS FLÁVIA BRITO DIAS PODCASTS NA EDUCAÇÃO: CONTRIBUIÇÕES ACERCA DE UMA LINGUAGEM EMERGENTE. 148

DOUGLAS MOTA XAVIER DE LIMA ROSIÂNGELA CAMPOS PICANÇO EDUCAÇÃO ON-LINE E CIBERCULTURA: A APRENDIZAGEM EM REDE ..165 EDNA MARTA OLIVEIRA DA SILVA 
A PARTICULARIDADE DA DEMOCRACIA NA REVOLUÇÃO BURGUESA NO BRASIL 189

EDUARDO SANTANA VALLI VERÔNICA NOGUEIRA ÂNGELO A COMOÇÃO ENQUANTO UMA ATITUDE ÉTICA: REFLEXÕES SOBRE SENTIMENTOS NA POLÍTICA A PARTIR DA CRÍTICA FEMINISTA $\ldots \ldots \ldots . .210$

FLÁVIA DA ROSA MELO

FLORA MORENA MARIA MARTINI DE ARAUJO AS ELEIÇÕES IMPERIAIS: O TEATRO DAS ELEIÇÕES EM SÃO JOSÉ DOS PINHAIS NA SEGUNDA METADE DO SÉCULO XIX 230

GLADISSON SILVA DA COSTA JOGANDO COM A IDADE MÉDIA: UMA PROPOSTA DE ESCAPE ROOM DIGITAL 254

MARIANA BONAT TREVISAN RENAN DA CRUZ PADILHA SOARES MARIA VAI COM AS OUTRAS: AS REPRESENTAÇÕES DA VIOLÊNCIA MIMÉTICA EM UM CONTO DE CONCEIÇÃO EVARISTO .......................290

THAYS CARVALHO CESAR AVALIAÇÃO NA GAMIFICAÇÃO: UM DIÁLOGO NECESSÁRIO 305 RENAN DA CRUZ PADILHA SOARES ANNE CAROLINA FARIA LIMA 


\section{APRESENTAÇÃO}

André Luiz Moscaleski Cavazzani Cleber Araújo Cabral

Ler, do latim legere, quer dizer captar com os olhos, mas também escolher as experiências culturais que se quer reunir e transmitir. Portanto, ao olharmos para o mundo, o lemos como uma trama de significados tecidos individual e coletivamente.

A partir dessa ideia de conceber o mundo como um livro de narrativas a ser explorado/desvendado por meio da leitura, foram reunidos, no volume que segue, trabalhos de professores dos cursos de Letras e História do Centro Universitário Internacional Uninter. A fim de expandir a proposta, convidamos, também, colegas de outras instituições de ensino, todos/as de alguma forma relacionados/as ao trabalho de reflexão sobre as relações entre estudos sobre Educação, História, Literatura e Linguística. Temas que, por sua vez, ocupam lugar central nas discussões e debates feitos ao longo de 2020, nos encontros mensais dos integrantes da linha de pesquisa Intersecções: língua, cultura, história e tecnologias.

Este esforço coletivo se materializou, portanto, no título da obra: Zootrópio: leituras de linguagens, tempos e sociedades. Zootrópio, significa "roda da vida" (zoe $=$ vida e tropos $=$ roda) e remete ao aparelho óptico criado em 1834 por William Georg Honer, que tinha o objetivo de projetar imagens e cenas cotidianas em movimento. Ao reunir estes textos, buscamos compor um painel que contempla diversos temas e perspectivas teóricas e metodológicas, como feitoanteriormente no livro Diorama: temas de História, Educação e Literatura. É importante salientar, portanto, que este volume pode ser entendido como uma sequência da coletânea Diorama, publicada em 2019. 
Como resultado dessa composição, entregamos aos leitores este zootrópio de temas e abordagens, um conjunto diversificado e, ao mesmo tempo, coeso e articulado de artigos, por meio do qual se pode contemplar, ainda que parcialmente, questões que movimentam a "roda da vida" social. Esperamos que as ideias aqui colocadas possam movimentar outras mais, trazendo cor, nuance e matiz, às reflexões do leitor que tomar esta obra em mãos.

Os organizadores. 


\title{
UMA ESPÉCIE EM VIAGEM: UMA REFLEXÃO SOBRE TRANSUMÂNCIA, DESENVOLVIMENTO REGIONAL E ENSINO SUPERIOR
}

\author{
André Luiz Moscaleski Cavazzani ${ }^{1}$ \\ Renata Adriana Garbossa ${ }^{2}$
}

\begin{abstract}
Somos una especie en viaje No tenemos pertenencias sino equipaje Vamos con el polen en el viento Estamos vivos porque estamos en movimiento Nunca estamos quietos, somos trashumantes Somos padres, hijos, nietos y bisnietos de inmigrantes Es más mío lo que sueño que lo que toco ${ }^{3}$

Jorge Drexler - Movimento.
\end{abstract}

Resumo: O texto apresenta reflexões sobre a articulação das dinâmicas da mobilidade populacional com a ideia de desenvolvimento regional. Numa primeira etapa do texto, apresenta-se uma discussão acerca das tipologias de mobilidade humana. Em seguida apresentam-se conceitos sobre desenvolvimento regional buscando- se indicar como estes dois processos mantém uma relação, mais do que tangencial, estreita.

Palavras-chave: Desenvolvimento regional. Migrações. Ensino superior.

Jorge Fernandes Alves, estudioso do fenômeno da emigração lusitana, certa vez observou: os homens se movem, e esta mobilidade transforma-

\footnotetext{
${ }^{1}$ Currículo Lattes: http://lattes.cnpq.br/2478425363350370.

2 Currículo Lattes: http://lattes.cnpq.br/6390490408506785.

3 Jorge Drexler - Movimento. Disponível em: https://genius.com/Jorge-drexler-movimiento-lyrics Acesso em: $17 / 05 / 2021$.
} 
se por vezes em emigração. (ALVES, 1998). Tal axioma bem poderia aplicar-se à formação histórica do Brasil que é, basicamente, uma história de deslocamentos populacionais, uma história de migrações, mas também de emigrações e imigrações. A expansão e consolidação dos domínios da coroa portuguesa nos rincões coloniais não foram outra coisa senão o efeito do comportamento preferencial do homem colonial: o movimento. Lusitanos, seus descendentes mamelucos, o gentio administrado, afrobrasileiros e seus ascendentes em diáspora, compunham uma população itinerante de desbravamento e povoamento, que se disseminava avançando pelos cantões do Brasil. (NADALIN, 2004) Aventureiros, homens "de grandes vôos", diria Sérgio Buarque de Holanda, olhando para o período colonial brasileiro.

Não ficamos apenas no Brasil. Os caminhos e descaminhos da humanidade são fruto de dinâmicas de movimento e sedentarização. Onde há vida há movimento, diria o estudioso da motricidade humana, André Lapierre (LAPIERRE, 2002). Em acordo, afirma o poeta Jorge Drexler, que nos serve de epígrafe, "estamos vivos porque nos movemos".

O texto que segue procura, com efeito, uma abordagem sobre as dinâmicas da mobilidade populacional. Para ser mais exato, trata-se de um estudo de caso, que pretende indicar exemplos de desenvolvimento regional encetado pelas migrações em busca de formação no ensino superior.

A humanidade se movimenta. Ao se movimentar se instrui, aprende, inventa, se reinventa, processo esse que acaba por abarcar a concepção de uma formação humana (nem sempre restrita aos meios de educação formal e, não raro, à revelia destes) sistêmica e que se prolonga até o fim da vida (GADOTTI, 2016, p. 68). 
Assim, o que queremos é discutir dois processos que mantém uma relação, mais do que tangencial, estreita: os processos de mobilidade e de instrução (ainda que seja de instrução formal).

Em primeiro lugar, Ihe será apresentado um breve panorama sobre a questão das mobilidades populacionais. Trabalharemos alguns conceitos e algumas tipologias aderentes aos fenômenos de transferência populacional. Indicaremos, também, algumas leituras. Num segundo momento, adensamos as análises colocando em perspectiva as relações entre migrações e o desenvolvimento regional que se dão a partir da instalação de instituições de ensino.

\section{Migrar, emigrar, imigrar: algumas aproximações.}

Migrar, emigrar, imigrar, independente do polo de saída e do polo de destino, estar em trânsito é uma marca da experiência de mobilidade. Assim, não raro as histórias de emigração e imigração aparecem associadas às temáticas de rompimento com a terra de origem e de recomeços com o a terra de destino. Os emigrantes sofrem daquilo que Alexandre Herculano denominaria de: dilaceramento do desaninho. Ou seja, ao deixar o polo de origem, abandonam relações, ligações, laços sociais que nem sempre conseguem reproduzir em equivalência no polo de destino. Neste, por sua vez, sofrem o impacto da alteridade e, nessa lógica, são "o outro" na terra de destino, mas, também, convertem-se em estrangeiros naquela original que trocaram pela aventura migratória. Tal situação, é forçoso salientar, pode acompanhar um conjunto de indivíduos em trânsito que não necessariamente cruzaram oceanos. Em curtas distancias, por vezes, no mesmo país, este fenômeno, qual seja, do impacto da alteridade pode se fazer presente. Nessa direção, abarcar o conceito de imigrante é algo bastante complexo e, no final das contas, bastante arbitrário. 
Tradicionalmente, considera-se migração o fenômeno de troca de país, estado, ou até mesmo bairro e domicílio. Imigração, por sua vez, é um conceito que abarca o movimento de entrada de indivíduos, por fim, emigração é caracterizado como o processo de saída dos indivíduos em trânsito. Ou seja, todos, sob certa perspectiva, estamos em movimento, somos migrantes.

No entanto, evidentemente, faz-se necessário buscar medidas mais concretas de apreensão desse fenômeno. A arbitrariedade - nesse caso - é inescapável. Charles Tilly, por exemplo, não está inclinado a considerar fenômeno migratório a mudança de uma casa para outra (TILLY, 1976). Mesmo assim, o autor ressalva o quanto esta escolha é complicada, uma vez que mesmo nesse caso o impacto da alteridade pode se fazer presente. O morador de uma casa em determinada região sentirá, com efeito, tal impacto ao se mudar para um condomínio diferente, ou para uma vizinhança diferente.

Norbert Elias, por exemplo, em seu livro Os Estabelecidos e Outsiders: sociologia das relações de poder a partir de uma pequena comunidade (ELIAS E SCOTSON, 2000) demonstrou como, numa mesma vizinhança (Winston Parva), se vão construindo relações de clivagem e hierarquização entre os estabelecidos há mais tempo e aqueles recémingressados. O impactante, conforme demonstra o autor, é que tal clivagem não se dava sobre o signo de diferenças étnicas, nível de desenvolvimento econômico ou educacional, nem mesmo de atividade profissional. Os moradores mais antigos - conforme demonstraram as análises recusavam-se a conversar com os novos, simplesmente porque, afinal, eles eram recém-chegados àquele bairro. Em síntese, mesmo compartilhando de uma mesma matriz sócio-cultural, circulando num espaço anglófono, os indivíduos recém-ingressados naquele loteamento sentiram o impacto da alteridade. Não é impossível que você, caro leitor, já se tenha visto nesta mesma situação. 
Reconhecendo, portanto, as doses de arbitrariedade ao tentar classificar este complexo fenômeno que envolve mobilidade populacional (espontâneo ou, mesmo, forçado - como foi o caso da diáspora africana nos períodos moderno e contemporâneo, por exemplo) e uma boa dose de alteridade, é possível traçar algumas tipologias e, além disso, levantar algumas variáveis que são relevantes. Em primeiro lugar, merece a atenção a distância entre origem e destino. Contudo, na equação que se arma a partir da variável distância entre polo de saída e polo de destino, devem-se acrescentar as diversas e complexas gradações de rompimento com as origens (de quem se colocou em transito). Eventos transitórios como viagens turísticas, deslocamentos internos de curta distância facilmente reversíveis, portanto, tendem a escapar do que poderia se chamar fenômeno migratório.

\section{Tipologias do movimento}

Portanto, considerando distância, duração e irreversibilidade, as migrações, conforme Charles Tilly (TILLY, 1978, p. 88) podem ser categorizadas da seguinte forma:

1) LOCAIS - deslocamentos provocados por oportunidades de trabalho, de moradias, ou, mesmo, buscando chances de relacionamento - mercado matrimonial - ocorrendo em um espaço de contiguidade geográfica, normalmente, familiar ao migrante;

2) CIRCULARES - deslocamentos caracterizados pelo retorno. Os sujeitos deslocam-se para determinada área com um lapso de tempo definido entre ida e volta. Um exemplo bastante enfático desta categoria migratória abrange a aventura de um sem número de portugueses "de torna viagem" que cruzaram o Atlântico rumo ao Brasil ao longo do 
século XIX. Após buscarem enriquecimento, voltavam enriquecidos a Portugal com hábitos de vida diferenciados e, uma vez retornados, recebiam ao lado do nome o epiteto de Brasileiro. (CAVAZZANI, 2013);

3) CARREIRA: nesse caso, o indivíduo se desloca em função de oportunidades de trabalho oferecidas por instituições às quais está vinculado profissionalmente. São, em suma, os deslocamentos de trabalho que abrangem uma miríade de situações que envolvem desde deslocamento de executivos de multinacionais ao deslocamento de clérigos piedosos de determinada ordem;

4) EM CADEIA: processo muito presente na história brasileira, o movimento deste tipo envolve redes de solidariedade, informações e incentivo mobilizadas por pioneiros, parentes, conhecidos, amigos, conterrâneos já instalados no polo de destino. Tais migrações também podem ser mobilizadas por incentivos estatais e/ou institucionais patrocinando ou, no limite, incentivando os expedientes migratórios.

Essas modalidades migratórias são, evidentemente, as mais usuais. Porém, não menos importante, como se trata de uma classificação, elas não devem ser vistas de maneira congelada. Antes, podem se interpenetrar, complementar, possuem algumas ambiguidades latentes. Contudo, servem de ponto de partida para uma apreensão preliminar do fenômeno aqui trabalhado. Como anunciamos, caro leitor, o fenômeno apreendido aqui busca entender as relações - de via de mão dupla - entre movimento populacional e desenvolvimento regional. As linhas que seguem buscam, portanto, apresentar um panorama que tem como pano de fundo o problema das migrações locais desencadeadas pela busca de melhores condições e oportunidades a partir de um mercado educacional que vai se estabelecendo em nível regional. A migração local é o ponto de partida, por certo, mas inevitavelmente ela apresentará resíduos ou aspectos das tipologias CIRCULARES E EM CADEIA. 


\section{Desenvolvimento regional: o caso do Brasil}

No Brasil, em toda a segunda metade do século XX, o debate sobre o desenvolvimento regional recebeu atenção especial, principalmente entre economistas e geógrafos. Para Raiher (2015), desde os anos de 1960 no Brasil, a educação e sua contribuição para o crescimento e o desenvolvimento das nações tem sido alvo de pesquisa econômica. Não é diferente em outros países, onde, para Dansero, Giaccaria e Governa (2009), revelam-se que, nos últimos 20 anos, o tema desenvolvimento local foi, progressivamente, assumindo importância central no debate sobre o desenvolvimento, não somente do ponto de vista teórico e de pesquisa, mas também político, operativo e prático, levando em consideração os aspectos migratórios.

Alvares, Kannebley, Júnior e Carolo (2003) comungam que a universidade é uma instituição que desempenha um papel tido como fundamental na formação de mão de obra qualificada do capital humano. Para além desta formação imediata, tem-se a formação de mão de obra qualificada e o desenvolvimento de novas habilidades e novas ideias que contribuem para a inovação, para o crescimento da produtividade, bem como, do desenvolvimento econômico.

Para além do debate, pode-se fazer uso a Rollim e Serra (2009) ao teorizarem que as universidades sempre deram contribuições para o desenvolvimento das nações. Entretanto, a preocupação com o papel que elas desempenham onde estão inseridas é recente e tem recebido crescente atenção em vários estudos, estabelecendo-se como um elemento-chave no processo de desenvolvimento das regiões. Dessa forma, "as regiões com maior possibilidade de desenvolvimento são aquelas que conseguem estabelecer um projeto político de desenvolvimento congregando os seus 
diferentes atores" (ROLIM; SERRA, 2009, p. 29). Ou seja, à luz de Righi e Ruppenthal (2013), essas instituições possuem missão de gerar e transmitir conhecimento, formar capital intelectual, incentivar as inovações e promover a transferência de tecnologias. Com isso, ocorre uma mudança não só nos indicadores econômicos, mas, sobretudo, no processo de inovação tecnológica, na formação de recursos humanos e na transformação das estruturas produtivas das regiões onde estão localizadas.

É salutar destacar que uma boa parte das expansões das universidades aconteceu fora dos grandes centros, nas chamadas cidades médias. Esse processo, comumente designado por interiorização do Ensino Superior, tem contribuído para o desenvolvimento das cidades em que são instalados os campos universitários, bem como para os municípios do entorno. Araújo afirma que "a presença dessas universidades em cidades médias tem um impacto imediato e significativo não somente na vida cultural, mas também no comércio e nos serviços locais" (2013, p. 168). Ou seja, refletindo em mudanças tanto para a dinâmica local quanto para sua atuação regional, reflexo do grande número de alunos que migram para regiões e localidades onde as universidades estão instaladas.

Na mesma linha teórica de Araújo (2013), Rolim e Serra (2009) também apresentam que, hoje, é inquestionável a importância das universidades tanto na produção da ciência, quanto no processo de inovação tecnológica e na formação de recursos humanos. Os autores ainda destacam que "o progresso social, o avanço da democracia, a melhor distribuição de renda e uma sociedade mais justa têm na educação um dos pilares de sua sustentação" (ROLIM; SERRA, 2009, p. 9).

Em outros países, como é o caso da Espanha, um estudo realizado por Sanfeliu (2011) sobre as relações espaciais entre a cidade e a expansão das universidades no país, apresenta elementos respeitáveis para se pensar a importância das universidades para o desenvolvimento regional no Brasil, 
principalmente para as cidades em que elas estão localizadas. Para exemplificar, no caso da Espanha, muitas das novas universidades foram implantadas em cidades médias, tendo dois propósitos claros: 1) em virtude do aumento de estudantes universitários e a notável vinda de outras regiões, ocasionando um fluxo migratório significativo, saturação de alunos nos grandes centros que visavam à necessária descentralização; 2) ia em direção ao interesse da sociedade e instituições locais de obter centros de estudos superiores. Além disso, em termos econômicos, os efeitos do investimento são mais facilmente internalizados em cidades médias, muito embora, para além dos efeitos de cunho econômico, tecnológico e empresariais, são percebidas transformações de diversas ordens, como impactos na estrutura urbana e nas próprias condições de gestão das cidades

O autor destaca três pontos importantes: primeiro que as sedes das universidades e dos campi universitários são enormes criadores de centralidade, por gerarem e articularem fluxos de mobilidade e atraírem mais dinâmica social, gerando efeitos multiplicadores na localização de diversas atividades econômicas. Um segundo ponto apresentado por Sanfeliu (2011, p. 2) refere-se às instalações que atuam como difusores da ecologia social por meio da incorporação de setores sociais dinâmicos ao território. O terceiro grande ponto apresentado diz respeito à localização da sede, que se converte em um referente urbano e territorial, um marco que para ele simboliza o conhecimento, a modernidade e a inovação e que goza de alta consideração por parte da população.

Além dos exemplos de outros países, o Estado brasileiro também, a partir dos anos 2000, passou por transformações em vários setores. Portanto, entre os anos de 2003 a 2014, o Brasil passou por mudanças significativas em vários campos, podendo destacar, na educação, o aumento expressivo da instalação de inúmeras universidades no interior do país. Isso contribui, sobretudo, na alteração da dinâmica do território, 
conforme a afirmação de muitos teóricos que há algum tempo têm se debruçado em pesquisar o tema, uma vez que as universidades geram, sistematizam e difundem conhecimentos científicos e culturais. São, desse modo, um importante instrumento de transformação social, econômica, de alteração da produção do espaço urbano, mudanças espaciais na estrutura urbana e, principalmente, em função dos fluxos migratórios decorrentes da instalação das mesmas.

De acordo com Benko (1999), estudar a questão local e regional implica estudar a intervenção humana no território, portanto,

[...] é a partir da análise de dados analíticos obtidos através de estudos de diferentes especialidades que se torna possível discernir, de entre acervos de casos particulares proporcionados pela região, certas leis fundamentais da lógica e da distribuição das atividades (BENKO, 1999, p. 2).

Como teoriza Brandão (2007), as discussões em torno do desenvolvimento regional e urbano devem partir de uma visão sólida de produção social do espaço, historicamente determinado, resultante de conflitos e consensos que se estruturam em torno do ambiente construído. Dessa forma, o conhecimento é percebido como o elemento chave para fazer com que ocorra o processo de crescimento e superação das disparidades regionais. Neste contexto, as Instituições de Ensino Superior (IES) estabelecem um papel central, pois são as principais responsáveis pela formação do capital humano nas regiões.

Sobre isso, Goddard (2007) e Almeida (2011) afirmam existir uma grande demanda para que as Instituições de Ensino Superior realizem a educação vocacional e profissional para as necessidades da economia regional. Os autores enfatizam a existência de uma relação entre a formação do capital humano, o Sistema de Educação Superior (Universidades) e o desenvolvimento regional como um debate incipiente 
dentro do arcabouço teórico do desenvolvimento econômico, com perspectivas de novos desdobramentos. No entanto, ainda existem muitas lacunas sobre como estabelecer a integração entre as Universidades e a região, ou seja, como fazer com que o capital humano, formado pelas Universidades, seja capaz de compreender a realidade local e, portanto, desenvolver as habilidades necessárias para ser o dinamizador da construção de um Sistema Regional de Inovação.

A influência das Universidades sobre determinadas regiões tem sido apontada como fator de transformações regionais e aparecem como destaques nas análises conjunturais, principalmente nas esferas regionais. Na concepção de Bacellar (2005), nas políticas de desenvolvimento, quer sejam nacionais ou regionais, pode ser destacada a importância das IES para a configuração do processo de desenvolvimento econômico regional, dada a existência de um amplo espaço que elas possuem para agir. Conforme a autora, não se pode mais apenas contar de forma única e exclusiva com a atração de empresas de grande porte, ou de novos empreendimentos, mas também de fomentar ações mobilizadoras para o desenvolvimento local através da formação do capital humano.

Lopes (2003) apresenta que, no que diz respeito às universidades, elas geram, sistematizam e difundem conhecimentos científicos e culturais. Ainda acrescenta que a universidade é um importante instrumento de transformação social e econômica em todos os países, o Brasil se destacando entre os países em desenvolvimento. Isso porque estas instituições são responsáveis por expressivas parcelas da geração e transmissão de conhecimentos, da produção, apoio e divulgação de pesquisas, dentre outros benefícios proporcionados à regionalidade. 


\section{Desenvolvimento local e migrações}

Sendo assim, as interações entre o desenvolvimento local e as migrações, cuja natureza e repercussões espaço-temporais são bastante heterogêneas, precisam ser analisadas conjuntamente, para não gerar limitações nas análises, sobretudo, porque o nível de desenvolvimento de uma região influencia as decisões de migrar e estas, por sua vez, têm impactos sobre o desenvolvimento, especialmente nas regiões de origem dos migrantes. Assim, para alguns teóricos as migrações possuem uma dinâmica interna própria, apresentando efeitos tidos como positivos sobre as estruturas das localidades de origem e destino dos migrantes, devendo, portanto, ser entendidas como um processo integrante do desenvolvimento econômico.

Dessa forma, a instalação de Instituições de Ensino Superior, atualmente, é uma das grandes responsáveis pelos fluxos migratórios nas diversas regiões. As migrações são parte integrante de um processo socioeconômico e possuem uma regularidade que pode ser observada sob a forma de fluxos, alguns dos quais, devido a sua importância para a dinâmica espacial da economia, assumem caráter estrutural e transformam-se em trajetórias desenhadas de acordo com as necessidades nacionais, pontua Brito (2002, p.18). Tais trajetórias migratórias estão intrinsecamente relacionadas aos processos de desenvolvimento e integração dos mercados brasileiros, funcionando como um mecanismo de transferência do excedente demográfico de regiões pouco dinâmicas para outras, onde a economia urbano-industrial mais se desenvolveu ou em que a fronteira agrícola se expandiu, conclui o autor.

As formas como estas trajetórias se articulam aos contextos históricos para atender as necessidades econômicas, sociais, políticas e demográficas constitui um padrão migratório. Este padrão é dinâmico, influencia e é 
influenciado por questões regionais, podendo inclusive contribuir para perpetuar o caráter desigual do crescimento (BRITO, 2002).

Para além do debate, na concepção de Taylor (1986), as causas e impactos das migrações devem ser estudadas de forma integrada em relação ao processo de desenvolvimento, contribuindo nas tomadas de decisões de migrar e estas, por sua vez, têm impactos sobre o desenvolvimento, especialmente nos países de origem dos migrantes. De tal modo, as migrações podem ser percebidas primeiro como um processo do desenvolvimento econômico, e que seja possuidor de uma dinâmica interna própria, gerando impactos positivos sobre as estruturas das localidades.

A natureza extremamente complexa dos processos migratórios exige um framework teórico que incorpore uma variedade de perspectivas (micro e macro) e de hipóteses. Contudo, devido à dificuldade de generalizar as causas e consequências do fenômeno, bem como às dificuldades de isolá-lo dos demais aspectos sociais, econômicos e políticos, não há uma única teoria aceita pelos estudiosos como capaz de explicar a dinâmica dos fluxos migratórios (como se iniciam e se perpetuam). Há, na realidade, uma quantidade significativa de teorias capazes de explicar determinados aspectos do processo migratório, mas nenhuma delas consegue explicar toda a sua complexidade (DE HAAS, 2008; BARRICARTE, 2010). Segundo Massey et al. (1993), várias são as perspectivas teóricas sobre as migrações, por ser, de acordo com a teórica, objeto de estudo de diversas áreas do conhecimento, resultando em muitos momentos de grandes controvérsias em relação tanto à natureza, quanto às causas e impactos dos fluxos migratórios.

Estudos de Oliveira e Oliveira (2011) mostram que, nas últimas décadas do século $X X$, o fenômeno das migrações tem apresentado transformações significativas, não só no território nacional, mas em outras partes do mundo. Dessa forma, até o presente momento, os principais 
fluxos migratórios têm se redirecionado para as cidades médias, em detrimento dos grandes centros urbanos. Dados publicados pelo REGIC 2020 (IBGE, 2020) mostram que a atração para cursar nível superior no tocante à oferta, houve grande modificação no panorama em todo o Território Nacional, dado pelo espraiamento de universidades públicas e privadas para além das grandes Capitais e Metrópoles, abarcando também cidades médias. A atratividade ocorreu não apenas pela instalação de cursos presenciais, mas também de polos de Educação a Distância - EaD, adicionando uma nova modalidade responsável por deslocamentos de frequência não diária na formação universitária pela população residente, sobretudo, fora das Metrópoles.

Como lembramos anteriormente, as migrações não constituem uma novidade, pois os homens se movimentam. Contudo, em cada época da história esse movimento se distingue nas causas que o motivam, nas modalidades dos deslocamentos e nas implicações.

Nesse caso, a abordagem que estamos realizando dá-se em função dos fluxos migratórios, principalmente de alunos que migram para municípios onde estão localizadas as universidades. Para Garbossa (2019) e Garbossa (2002) a migração de alunos, professores e técnicos administrativos vindos de diversos estados brasileiros e até de outros países confere aos municípios onde estão instaladas as Universidades uma maior diversidade cultural, econômica e social.

Nesse cenário, de acordo com o REGIC 2020 (IBGE, 2020), no Brasil, a educação continuada constitui importante elemento de transformação social e espacial. A formação em grau universitário, como em outros setores que abrangem a distribuição de equipamentos e serviços educacionais, possui uma lógica locacional desigual que, de certo modo, privilegia os centros urbanos de maior hierarquia, assim como alcança, diferentemente, os diversos segmentos sociais. 
Ou seja, o deslocamento de grande fluxo migratório de alunos, professores e técnicos administrativos contribui significativamente para o desenvolvimento local e regional, em função da forte demanda que esse grupo incita por locação ou compra de imóveis, alimentação, transporte, lazer, uso dos espaços públicos. São fatores que contribuem para a melhoria tanto dos indicadores econômicos, em que os resultados da escolaridade são refletidos em um maior grau de produtividade e, ao mesmo tempo, em um aumento na taxa anual de crescimento do salário médio real como proxy da produtividade do trabalho em todos os setores, com destaque para os serviços. Desse modo, os ganhos de produtividade do trabalho verificados nos setores de atividade econômica tiveram impacto sobre o comportamento dos salários reais, afirma Garbossa (GARBOSSA, 2019, p. 68). Portanto, os movimentos migratórios são importantes para a análise geográfica, pois por meio deles podemos entender as dinâmicas territoriais ao longo do tempo em várias escalas, sejam elas regionais, nacional ou global.

\section{REFERÊNCIAS}

ALVES, J. F.. Terra de Esperanças - o Brasil na emigração portuguesa. In: Portugal e Brasil - Encontros, desencontros, reencontros. Cascais: Câmara Municipal, VII Cursos Internacionais, 2001.

ALMEIDA, M. H. T. de. Federalismo e Políticas Sociais. In: Revista Brasileira de Ciências Sociais. São Paulo: ANPOCS, n. 28, 1995, p. 87-108.

BACELLAR, T. A. Desenvolvimento regional brasileiro e políticas públicas federais no Governo Lula. In: SADER, E. (Org.). 10 anos de governos pós-neoliberais no Brasil: Lula e Dilma. São Paulo: Boitempo, 2013, p. 157171.

BENKO, G.. Economia, espaço e globalização: na aurora do século XXI. 2. ed. São Paulo: Hucitec, 1999.

BRANDÃO, C.. Território e desenvolvimento: as múltiplas escalas entre o local e o global. Campinas: Ed. Unicamp, 2007.

BRITO, M. S.; BRICEÑO, M.. Proposta para a introdução da perspectiva de gênero no processo de desenvolvimento local. Projeto BNDES, Desenvolvimento Local, Cooperação Técnica do Programa das Nações Unidas para o Desenvolvimento (PNUD), 2002.

HOLANDA, S. B. de. Raízes do Brasil. Rio de Janeiro, 2003.

DINIZ FILHO, L. L.. A Dinâmica Regional Recente no Brasil: Desconcentração Seletiva com "Internacionalização" da Economia Nacional. Número de folhas (ex.: $220 \mathrm{fl}$ ) (Tese de Doutoramento em...). Departamento de Geografia da Faculdade de Filosofia, Letras e Ciências Humanas, Universidade de São Paulo, São Paulo, 2000.

DINIZ, C. C.. Repensando a Questão Regional Brasileira: Tendências, Desafios e Caminhos. Painéis sobre o desenvolvimento brasileiro, sob o patrocínio do BNDES. Rio de Janeiro, 2002.

FURTADO, C.. Introdução ao desenvolvimento: enfoque histórico estrutural. 3. ed. São Paulo: Paz e Terra, 2000.

FURTADO, C.. Brasil a construção interrompida. 3. ed. Rio de Janeiro: Paz e Terra, 1992.

FURTADO, C.. Dialética do desenvolvimento. 2. ed. Rio de Janeiro: Ed. Fundo da Cultura, 1964. 
GADOTTI, M. Educação popular e educação ao longo da vida. In: CONFINTEA +6, 2016, Brasília. Coletânea de textos CONFINTEA +6. Brasilia: Ministério da Educacão, 2016. v. 1. p. 50-69. Disponível em: <https://www.paulofreire.org/images/pdfs/Educacao_Popular_e_ELV_Gadotti.pdf>. Acesso em 12/04/2021.

GARBOSSA, R. A.. Expansão e interiorização da Universidade Tecnológica Federal no estado do Paraná: efeitos no desenvolvimento local. 309 fl. (Tese de Doutorado em Geografia). Programa de Pós-Graduação em Geografia, Setor de Ciências da Terra, Universidade Federal do Paraná, Curitiba?, 2019.

GARBOSSA, R. A. S.. Instituições Públicas de Ensino Superior no Estado do Paraná e o desenvolvimento local e regional. In: OLIVEIRA JUNIOR, Antonio de (Org.). Expansão do ensino superior \& Desenvolvimento Local e Regional. . Belo Horizonte: Editora Barlavento, FAPEMIG, 2020.

GIACCARIA, E.; DANSERO, P.; GOVERNA F.. O desenvolvimento local: contextos nacionais em confronto. In.: SAQUET, Marcos Aurelio; SPOSITO, Eliseu Savério (Org.). Territórios e Territorialidades: Teorias, Processos e Conflitos. 1. a edição Editora Expressão Popular São Paulo - 2009.

GODDARD. Higher Education and Regional: Globalls Competitive, locally engaged. OCDE, 2007.

LOPES, R. P. M.. Universidade Pública e Desenvolvimento Local: uma abordagem a partir dos gastos da Universidade Estadual do Sudoeste da Bahia. Vitória da Conquista: Edições Uesb, 2003.

MORAES, A. C. R.. Território e História no Brasil. 2. ed. São Paulo: Annablume, 2005.

NADALIN, S. de O. A população no passado colonial: mobilidade vs estabilidade. Topoi (Rio de Janeiro) [online]. 2003, v. 4, n. 7, p. 222-275. <http://www.revistatopoi.org/numeros_anteriores/Topoi\%2007/topoi7a2.pdf >. Acesso em: 17/08/2018.

OLIVEIRA, L. A. P. de; OLIVEIRA, A. T. R. de. (Org.). Reflexões sobre os deslocamentos populacionais no Brasil. Rio de Janeiro: IBGE, 2011.

RAIHER, A. P. (Org.). As universidades estaduais e o desenvolvimento regional do Paraná. Ponta Grossa: Editora UEPG, 2015.

RIGHI; Moacir Luiz; RUPPENTHAL Janis Elisa. A influência de uma universidade na geração de um polo regional de ensino superior. In: ABCustos Associação Brasileira de Custos, V.VIII, n 1, jan.-dez./ 2013.

ROLIM, C. F. C.; SERRA, M. A. Universidade e desenvolvimento regional: o apoio das instituições de ensino superior ao desenvolvimento regional. Curitiba: Juruá, 2009.

SANFELIU, C. B. La inserción de la universidad em la estrutura y forma urbana, el caso de la Universitat de Lleida. In: Scripta Nova, Barcelona, v. 14, n. 381, p. 1-25, nov./ 2011.

SANDRONI, P.. Dicionário de Economia do Século XXI. 3. ed. Rio de Janeiro: Record, 2007.

SAQUET, M. A.; SPOSITO, E. S. (Org.). Territórios e Territorialidades: Teorias, Processos e Conflitos. 1.ed. São Paulo: Expressão Popular, 2009.

SEN, A.. Desenvolvimento como Liberdade. Trad. Laura Teixeira Motta. São Paulo: Companhia das Letras, 2010.

SINGER, P. Migrações internas: considerações teóricas sobre seu estudo. In: Moura, H.A. de (Coord.). Migração Interna: textos selecionados. Fortaleza: Banco do Nordeste do Brasil - BNB, Escritório Técnico de Estudos Econômicos do Nordeste, 1980. T. 1, p. 211- 244 (estudos econômicos e sociais).

TAYLOR, J. Edward. Differential migration, networks, information and risk. In: Stark, Oded (Ed.). Migration theory, human capital and development. Greenwich, CT: JAI Press, 1986.

TILLY, C. Transplanted Networks. In: YANS-MACLAUGHLIN, Virginia (org.). Immigration reconsidered: History, sociology and Politics. Oxford: Oxford University Press, 2011, p. 79-95.

TRIGAL, Lorenzo López;DEL POZO, Paz Benito. Geografia Política. Madrid: Cátedra, 1999. 


\title{
ROMANTISMO E IDEALISMO ALEMÃES: FUNDAMENTOS ARTÍSTICOS, HISTÓRICOS E FILOSÓFICOS DO SÉCULO XVIII
}

\author{
Carolina Meire de Faria ${ }^{4}$
}

\begin{abstract}
$\mathrm{Na}$ estrutura do pensamento crítico e sistemático age o elemento romântico, panteísta e místico, a princípio ainda como um corpo estranho, que só lentamente o impregna e o desvia do seu caminho recto (HARTMANN - A Filosofia do Idealismo alemão)
\end{abstract}

Resumo: Este artigo busca apresentar a multiplicidade de influências políticas, culturais, artísticas e filosóficas que estão na base do pensamento alemão do século XVIII. Com base em uma breve exposição das teorias e autores do período, refletiremos acerca dos fundamentos e singularidades que performaram a Alemanha do período.

Palavras-chave: Romantismo. Idealismo. Arte. História. Filosofia.

\section{Introdução}

Contextualizaremos nas próximas linhas a atmosfera intelectual que fomentou o Idealismo e o Romantismo alemães, ocorridos na segunda metade do século XVIII e no início do XIX. Tal abordagem se faz necessária porque, ao analisarmos os aspectos múltiplos de uma cultura, podemos

\footnotetext{
${ }^{4}$ Currículo Lattes: http://lattes.cnpq.br/5029393820653809.
} 
compreender o fundamento das escolhas elegidas em uma época. A finalidade de tal estudo, portanto, é a investigação das contribuições dos movimentos artísticos, históricos e filosóficos para o surgimento de uma atmosfera que perpassa o pensamento alemão do período delimitado para este trabalho. Tal propósito será obtido através de revisão bibliográfica de textos, temas e autores que se encontravam em discussão na França e na Inglaterra do século XVIII e que foram tomados como referências pelos germanos para refletirem sobre seu contexto. A análise demonstrou que os pressupostos de alguns teóricos alemães, como Johann Joachim Winckelmann e Gotthold Ephraim Lessing, importantes expoentes da história da arte e da dramaturgia alemã, foram centrais para a criação de uma identidade cultural alemã específica que tem em sua base uma relação entre política, arte e filosofia. Vejamos adiante de que modo estará exposto esse panorama.

No século XVIII, a cultura e a literatura alemãs são, conforme interpretação de Otto Maria Carpeaux, ainda incipientes. Econômica e culturalmente defasada, pelo menos algumas décadas em relação à Inglaterra e à França, a Alemanha, entre meados do século XVII e o início do século XVIII, é uma nação iletrada e separada em pequenos principados. Naquele momento, o país ainda não havia se constituído como um Estado nacional, o que ocorrerá somente em 1871, sendo então formado por pequenos reinos, grão-ducados, cidades livres e territórios imperiais, apresentando divergências políticas e culturais enormes. Esse cenário provoca um "grande silêncio" do espírito que fará da Alemanha, naquele contexto, "o único país da Europa civilizada sem literatura alguma" (CARPEAUX, 1956, p. 37).

De acordo com o crítico literário, os alemães cultos do período, grupo composto por burocratas a serviço das Cortes e nobres que consumiam e produziam arte, utilizavam o Francês ou o Latim (nas Universidades) como línguas de cultura (CARPEAUX, 1956, p.37). Tal predomínio se devia à 
centralidade ocupada pela cultura e pelo pensamento franceses na Europa pós-Renascimento, atitude que perdura até o século XVII. Todavia, durante o século XVIII emerge o Racionalismo que, partindo da "França (Bayle, Fontenelle) e da Inglaterra", se espalha pelos outros países europeus, fomentando o surgimento de um novo modo de pensar (CARPEAUX, 1956, p.38). Na Alemanha, esse racionalismo filosófico e literário, "em parte importado da França", ocasionará um processo de mudança significativa: a cultura da Aufklärung (Esclarecimento ou Iluminismo), ocorrida entre 1720 e 1785 (LÖWY; SAYRE, 2015, p. 76).

Conjuntamente às ideias de Jean-Jacques Rousseau e às aspirações libertárias que culminam na Revolução Francesa, que fomentam a possibilidade de novos pensamentos políticos e culturais na Europa, a Aufklärung, constituirá o fundamento de uma mentalidade burguesa alemã. Essa mentalidade estava a se constituir, alicerçada, de um lado, "sobre um certo moralismo religioso e, de outro, sobre uma ética da educação, da racionalidade e do método" (LÖWY; SAYRE, 2015, p. 76).

Embora repouse sobre essas visões de mundo, começa a se delinear, progressivamente, uma identidade germânica própria, distinta da cultura e do pensamento filosófico e literário franceses. Essa atitude culminará na modernidade filosófica e literária alemã, um "renascimento à germânica", que toma corpo no Idealismo e no Romantismo. Assim, é necessário destacar a centralidade que a relação estabelecida entre as diferentes áreas do conhecimento ocupa no contexto, pois, segundo René Wellek e Austin Warren (1966, p. 136), não se pode desconsiderar que "a colaboração entre filosofia e literatura na Alemanha foi, de forma reiterada, extraordinariamente íntima", especialmente no período a que chamamos de Romantismo. 


\section{Razão, Sentimento e os gregos: o ambiente intelectual alemão dos sécs. XVII e XVIII}

Para pensarmos este contexto, cabe destacar, a princípio, a recepção do teatro de William Shakespeare (1564-1616), ocorrida a partir das traduções em prosa publicadas entre 1762 e 1766 por Christoph Martin Wieland (1733-1813). De acordo com Otto Maria Carpeaux (1963, p. 51), "os alemães do século XVIII não possuíam teatro; e tinham fracassado as tentativas de criá-lo a partir da imitação dos trágicos franceses". O crítico teatral e dramaturgo Gotthold Ephraim Lessing (1729-1781), na obra Dramaturgia de Hamburgo (1767), critica o teatro clássico francês, sobretudo a leitura do teatro grego empreendida pelo movimento conhecido como Plêiade e, como alternativa, aconselha aos dramaturgos alemães a tomarem as obras de Shakespeare, e seus personagens, como medida para a elaboração de um teatro nacional. Tal escolha toma por base aquilo em que consiste a genialidade shakespeariana para Lessing: a possibilidade de mostrar "a reviravolta", a "expressão barroca do sentimento", que nos conduz ao final, às "reproduções naturais da vida humana" (LESSING, 2005, p. 102).

Nas palavras de Carpeaux, a tradução das peças do autor de Macbeth, feita por Wieland, é o acontecimento literário que anuncia o préromantismo e divide a história da literatura alemã do século XVIII em "duas fases: antes de Shakespeare-Wieland e depois de Shakespeare-Wieland" (CARPEAUX, 1963, p. 47). Assim, conforme sugere o autor de História da literatura alemã, o dramaturgo inglês é visto pelos pré-românticos alemães como o "gênio selvagem da Natureza", sendo o indeciso e sentimental Hamlet eleito como o retrato e destino em que se reconhecem os jovens alemães (CARPEAUX, 1963, p. 58).

Outro elemento decisivo oriundo da cultura inglesa consiste na nostalgia das épocas passadas, seja a Idade Média ou a Antiguidade 
clássica. ${ }^{5}$ Essa melancolia se manifesta na prosa ritmada, nos versos sem rima e no temário dos poemas ossiânicos ${ }^{6}$ do escocês James Macpherson (1736-1796), mas, sobretudo, pelo volume Reliques of Ancient English Poetry (PERCY, 1927 [1765]), editado pelo bispo Thomas Percy (17291811). Esta obra, responsável pelo renascimento das baladas no Romantismo inglês, apresenta uma coleção de poesias camponesas tradicionais e de baladas escocesas. Nesta poesia, segundo Carpeaux, os literatos alemães encontrarão as "estrofes simples, os sentimentos elementares, a eliminação do descritivo [...] que serão determinantes da poesia lírica alemã" (CARPEAUX, 1963, p. 58).

O terceiro elemento consiste no pensamento do filósofo francês JeanJacques Rousseau (1712-1778). Em sua obra, o Discurso sobre a origem e os fundamentos das desigualdades entre os homens (1754), o pensador tece reflexões acerca da origem e da condição humana primeva sintetizada na imagem harmônica e livre desta com a natureza:

\begin{abstract}
Ora, nada é mais suave do que ele em seu estado primitivo, quando colocado pela natureza a distâncias iguais da estupidez dos brutos e das luzes funestas do homem civil, e igualmente conduzido pelo instinto e pela razão a se proteger do mal que o ameaça, ele é impedido pela piedade natural de fazer mal a alguém, uma vez que nada o leva a isso, mesmo depois de o ter recebido de outro.
\end{abstract}

Assim, os homens em seu estágio primeiro viviam [...] livres, saudáveis, bons e felizes, tanto quanto podiam sê-lo graças a sua natureza [...] (ROUSSEAU, 2002 [1754], p. 17-18)

Essas ideias são desenvolvidas de modo a refletir sobre as relações individuais e coletivas dentro da sociedade e de seu corpus jurídico e político. Nessas análises, que partem na busca de fundamentos, a natureza recebe um lugar central passando a exercer, segundo compreendemos, ao

\footnotetext{
${ }^{5}$ Cf. LÖWY; SAYRE, 2015, p. 77-78.

${ }^{6}$ Os escritos de James Macpherson em 1760, a respeito do bardo escocês Ossian são considerados a maior fraude literária da história. O autor teria publicando os poemas de sua autoria como se fossem os poemas de Ossian. C.f estudos a esse respeito em BOLD, 2005, p. 193-204.
} 
menos três vieses diferentes e complementares: o de uma entidade, um espaço de vivência pura; o estado humano primordial; o princípio diretivo do homem.

A primeira dessas concepções é encontrada na obra acima referenciada, quando Rousseau indica certos "dons oferecidos pela Natureza" que, diante das limitações humanas, não foram passíveis de desfrute (ROUSSEAU, 2002 [1754], p. 9). Posteriormente, n'O contrato social (1762), o conceito da natureza será considerado pelo filósofo francês como consequência de uma propriedade inerente, ou seja, uma condição sine qua non para o ser humano e que, por isso, não pode ser rejeitada por ele ante a perda da "qualidade de homem, aos direitos da humanidade, até mesmo a seus deveres" (ROUSSEAU, 2002 [1762], p. 59- 64).

Em seu escrito pedagógico, Emílio ou a Educação (1762), o filósofo enfrenta a terceira definição do termo natureza, na tentativa de circunscrevê-la diante de seu "sentido vago demais". Desse modo, propõe que:

\begin{abstract}
[...] desde nosso nascimento somos afetados de diversas maneiras pelos objetos que nos rodeiam. Tão logo tenhamos, digamos, consciência de nossas sensações, estaremos prontos para buscar ou evitar os objetos que as produzem, inicialmente, por serem agradáveis ou desagradáveis, depois pela conveniência ou falta de conveniência que encontramos entre nós e esses objetos e, finalmente, pelos julgamentos que fazemos da ideia de felicidade ou perfeição que a natureza nos dá. Estas disposições se estendem e se afirmam à medida em que ficamos mais sensíveis e mais esclarecidos, mas, pressionados por nossos hábitos, elas são mais ou menos alteradas por nossas opiniões. Antes desta alteração elas são o que chamo em nós a natureza. (ROUSSEAU, 2002 [1752], p. 90)
\end{abstract}

Deste modo, nos parece que a visão rousseauniana da natureza não é unívoca, pois pode ser pensada desde o âmbito da política da lei natural até a ideia de um regresso à inocência do mundo, vista no território e no 
homem. Outros aspectos de influência do pensamento de Rousseau para o contexto consistem, segundo Carpeaux: no "culto ao povo, contra as limitações" da aristocracia; um louvor ao sentimento e à intuição do homem como crítica e em contraste às "imposições da razão" (CARPEAUX, 1963, p. 59).

Assim, o filósofo francês foi considerado por Michael Löwy e Robert Sayre como o "autor-chave na gênese do romantismo francês, porque já na metade do século XVIII soube articular através de suas teses toda a visão do mundo romântico" posterior (LÖWY; SAYRE, 2015, p. 79). Além disso, cabe salientar, o comentário de Henri Bergson (1859-1941) sobre a importância das teorias da natureza, da Naturphilosophie cujas teses estariam no cerne das reflexões filosóficas do século XVIII. Segundo esse filósofo, o pensamento francês foi responsável, em grande medida, por essas ideias, possuindo perspicácia em articulá-las. (BERGSON, 2006 [1915], p. 260). Desse modo, desde René Descartes (1596-1650) e no interior de suas teses já encontraríamos

[...] uma teoria do espírito ou, como diz Descartes, do "pensamento", um esforço para resolver o pensamento em elementos simples: este esforço abriu caminho às pesquisas de Locke e de Condillac. Encontraríamos sobretudo esta idéia que o pensamento existe primeiro, que a matéria é dada por acréscimo e poderia, a rigor, existir apenas como representação do espírito. Todo o idealismo moderno saiu daí, em particular o idealismo alemão. (BERGSON, 2006 [1915], p. 258).

Essas teorias teriam inspirado, segundo Bergson, o "kantismo", o "romantismo alemão" e, especialmente a arte e a literatura germânicas. (BERGSON, 2006 [1915], p. 262).

Outro elemento de relevo do período é a mentalidade mística da época, como o misticismo espanhol, a prática espiritual do quietismo francês e o pietismo suábio, que substituem o livre exame racional pelo 
mistério. Sobre o pietismo, deve-se mencionar sua importância tanto no pensamento quanto na arte romântica alemã. De acordo com a pesquisa de Micheal Löwy e Robert Sayre acerca das origens do Romantismo na Inglaterra, França e Alemanha, nesta sobressai a influência direta que Johann Albrecht Bengel (1687-1752) e seu discípulo, Friedrich Christoph Oetinger (1702-1782), ambos inspirados por Mestre Eckhart e Jakob Böhme, terão na composição da "Naturphilosophie do romantismo, de Schelling a Franz van Baader" (LÖWY; SAYRE, 2015, p. 80). Ainda sobre esse ponto, de acordo com Löwy e Sayre, não se pode desconsiderar a importância do teólogo e poeta pietista Johann Georg Hamann (1730-1788) e seu discípulo, o filósofo Johann Gottfried von Herder (1744-1803). Ambos propunham a ênfase na experiência religiosa pessoal, a crítica ao racionalismo e sua substituição pela intuição e pelo mistério (LÖWY; SAYRE, 2015, p. 80).

E, por fim, cabe mencionar as discussões empreendidas no que se refere à crítica literária e à história. A esse respeito, Johann Gottfried von Herder (1744-1803) constitui um dos responsáveis pelas novas reflexões surgidas nesses campos. ${ }^{7}$ Segundo Constantino Luz de Medeiros, é a partir dos escritos fragmentários Sobre a mais nova literatura alemã (Über die neuere Deutsche Litteratur, 1767), de Herder, que tem início "a questão da discussão sobre a continuidade e da necessidade de alteração no paradigma crítico literário da Alemanha" (MEDEIROS, 2018, p. 21).

Para o autor de Ideias de uma filosofia da história da humanidade (1784-1791), tais paradigmas se referem a pensar a recepção e a tradução das obras antigas em relação a sua temporalidade. Isso significaria refletir sobre o contexto histórico de cada gênero e obras por um incurso que toma todo o contexto de uma época como orientação. Desse modo, não é

\footnotetext{
7 Johann Joachim Winckelmann, foi também responsável pela perspectiva histórica desenvolvida no contexto, o que se fez, especialmente, pelas formulações acerca dos antigos que desenvolve em suas reflexões sobre a arte, como veremos de forma mais detalhada no próximo tópico deste artigo.
} 
desejável buscar, por exemplo, em Aristóteles, regras atemporais para se compor uma peça dramática, tais como as orientações sobre unidade e efeito, mas, antes, atentar-se ao contexto de produção do teatro grego, buscando nele os fundamentos para se compor. Tal formulação, em suma, propõe olhar para o passado de forma crítica, pensando no presente, no espírito de cada povo e de cada época, relativizando-se normas estáticas que visavam a orientar a composição artística.

Ainda na esteira desse ambiente estético e artístico pré-romântico alemão, sobressai, de acordo com Marco Aurélio Werle (2000), a importância do movimento cultural surgido à época, Tempestade e ímpeto [Sturm und Drang] (1765-85), que consistiu na tentativa de emancipação das letras nacionais. Conforme esclarece o autor, embora pareça uma radicalização do espírito da Ilustração, esse movimento

[...] constituiu-se como uma luta contra a ilustração, uma luta de jovens espíritos (Hamann, o mago do norte, Herder, Goethe, Lenz e até Schiller), cujos temas básicos eram: a incompatibilidade entre o indivíduo e a sociedade, o que resultava numa dor do mundo (Weltschmerz); a ênfase no gênio criador que se afirma livre das regras artísticas (deve-se dar vazão aos impulsos naturais e vigorosos); o acentuado individualismo nas artes; 0 sentimentalismo [...] (WERLE, 2000, p. 23).

No mesmo sentido, o crítico literário brasileiro Massaud Moisés (1978) sintetiza tal movimento pelo destaque de três de seus aspectos: 1) o repúdio à Aufklärung; 2) o "regresso ao irracionalismo, aos valores do espírito, ao sentimento"; e 3) ao:

[...] gosto pela simplicidade e a consequente recusa da civilização, o pleno gozo da liberdade criadora, do gênio individual contra as regras clássicas, da intuição sobre a Razão, da inspiração sobre a erudição, do subjetivismo contra o objetivismo (MOISÉS, 1978, p. 484). 
Para Carpeaux, esse pré-romantismo alemão, tal como o restante do europeu, também consistiu em uma contraposição ao racionalismo das Luzes, postulando o sentimento e a intuição contra o despotismo do entendimento (Cf. CARPEAUX, 1963, p. 59). Segundo Marco Aurélio Werle, no que se refere às contribuições em termos de história da estética, esse movimento incorpora a posição germânica da época amparada pela:

1. referência à Idade Média (o que também será usual junto aos românticos); 2 . crítica a Aristóteles em vista do pouco espaço dado aos caracteres no drama; 3. redescoberta, entre os antigos, de Homero e, entre os modernos, de Shakespeare; 4. Valorização da figura do gênio (influência inglesa) e do princípio da natureza (Rousseau) (WERLE, 2000, p. 23).

Assim, da recepção dessa mescla cultural, resultam reflexões a respeito de argumentos caros ao Iluminismo, tais como a primazia do método científico para as especulações acerca da natureza e as orientações racionalistas e mediadas pela análise formal. Disso resulta, de acordo com Erich Auerbach, um pensamento alemão assentado na crítica a cultura

[...] artificial, estreita, falsa, longe da natureza e distante do povo; parecia-Ihes sufocar o gênio com as regras e a nobreza petrificada e seca da linguagem. Quanto a eles, adoravam a poesia popular e o teatro de Shakespeare; escreviam tragédias desprezando as unidades de tempo e de lugar, misturando o trágico ao realismo saboroso, servindo-se de uma linguagem vigorosa popular, não evitando sequer as expressões grosseiras, embora se mantivessem profunda e pateticamente idealistas (AUERBACH, 2005, p. 346347).

As recepções europeias das culturas francesa e inglesa, nessa reformulação da sociedade e do pensamento germânico, extrapolam, portanto, as ideias estéticas e filosóficas, ocorrendo, como visto, também 
no âmbito político, estimulando a formação das ideias de nação e de identidade cultural.

Simultaneamente ao Iluminismo ${ }^{8}$ e pelas reflexões tensionadas pelo Sturm und Drang, ocorrem, o Classicismo de Weimar e o Romantismo. Suas figuras expoentes são Friedrich Schiller (1759-1805) e Johann Wolfgang von Goethe (1749-1832), autores que participaram do pré-Romantismo, tornando-se protagonistas dessa nova fase da literatura alemã - embora não se deva a eles a exclusividade do florescimento classicista de Weimar.

O Classicismo (1795-1803), caracterizado pela busca da simplicidade, ${ }^{9}$ ao retorno a uma arte pura, observados especialmente nos estudos sobre a composição poética da antiguidade, "buscava imprimir à Alemanha uma feição de uma 'Grécia estilizada', 'apolínea', sem manchas de fealdade, sem exaltações menos decorosas" (CARPEAUX,1963, p. 70). No mesmo sentido, Massaud Moisés $(1978$, p. 358) salienta que a Alemanha desse período era marcada pelo "'amor eterno à Hélade', que traduzia um acendrado e obsessivo culto à Beleza", manifesto na obra de poetas, pintores, escultores, assim como no bojo das teorias estéticas.

Nesse caso, a análise do paradigma de composição artística do Classicismo, que se orientou pelas poéticas da Antiguidade e, especialmente, as teorias de Platão e Aristóteles, levou em conta um binômio para a orientação na composição. De um lado, a criação de obras literárias deveria obedecer aos modelos ideais greco-latinos de estrutura textual e narrativa (Regras exteriores da obra); de outro, as diretrizes para criar obedecem a uma regulação da imaginação, porém, sem sufoca-la, de modo a promover o equilíbrio necessário entre razão e sensibilidade,

\footnotetext{
${ }^{8}$ Cabe esclarecer que, embora o Iluminismo pareça estar ausente nos movimentos literários posteriores, ele se encontra de fato matizado no interior de conceitos tais como o de aperfeiçoamento de infinito.

${ }^{9}$ Essa simplicidade estoica já se encontrava na percepção winckelmanniana dos gregos, não surgindo apenas no classicismo, como veremos adiante.
} 
criando assim as condições para que os fins do Belo, do Bem e do Verdadeiro pudessem vir à tona na obra de arte (Regras interiores da obra).

Tais proposições intentavam produzir o elo e a justa medida entre a natureza humana ideal e a natureza divina. O que, em dimensão mais ampla, espraiaria os valores do Belo na vida física, estética, filosófica, cultural e comunitária, criando o sentido de identidade - pelo viés de uma Bildung, conceito que sintetiza, segundo Rosana Suarez (2006, p. 192), "[...] o processo da cultura, da formação", que estava a se fomentar na Alemanha do período.

Por fim, temos o Romantismo e sua relação com a Filosofia, que se inicia, segundo Nicolai Hartmann, na década de oitenta do século XVIII, com a publicação da Crítica da Razão Pura (1781), de Immanuel Kant (1724-1804) (HARTMANN, 1983, p. 09). Tal movimento, assaz complexo, é, segundo Edward Mcnall Burns (1970), uma síntese da "teoria romântica da verdade com a concepção idealista do universo, isto é: não era nem racionalista e nem materialista no sentido rigoroso destes termos" (BURNS, 1970, p. 646). Desse modo, se constituiu, conforme a leitura de Erich Auerbach, mais por uma "atmosfera poética" do que por uma "unidade sistemática", pois reúne, ao mesmo tempo,

[...] simplicidade popular e refinamento individualista, tendências conservadoras e germes revolucionários, lirismo brando e ironia amarga, devoção e orgulho, entusiasmo e desespero nele se entremesclam, por vezes numa mesma personalidade (AUERBACH, 2005, p. 354).

Cabe mencionar, ainda, que as implicações do Romantismo dialogam também com a fortuna filosófica, literária, cultural e crítica da época, tributária, em larga medida, da filosofia idealista kantiana. Tal sistema filosófico, antevisto na leitura conjunta da Crítica da Razão Pura (1781), Crítica da Razão Prática (1788) e Crítica da Faculdade de Julgar 
(1790), também conhecidas como $1^{a}, 2^{a}$ e $3^{a}$ Críticas, foi responsável por destacar os limites do entendimento, por redimensionar a reflexão sobre o conhecimento dos objetos enquanto fenômenos e o acesso ao mundo das coisas-em-si (propriamente acessíveis ao entendimento). Essa reflexão demonstrou que o conhecimento não ocorre exclusivamente no campo especulativo, mas que é tecido por uma articulação que se opera no âmbito das relações.

As implicações de um projeto como esse acentuaram o lugar do sujeito enquanto agente principal do vínculo entre sujeito $x$ objeto, e o lugar de uma filosofia prática, do agir, no processo apropriador da realidade. Outras implicações das reflexões kantianas se referem aos estudos sobre as antinomias, o infinito, o universal, a liberdade, as emoções, especialmente no que tange ao lugar do prazer, do sentimento e da beleza, os quais se imprimiram no pensamento estético da época, na figura do gênio, da imaginação, do sublime e do engenho.

Outro nome de relevo do período é Johann Gottlieb Fichte (1762 1814). Este pensador se opôs ao binômio kantiano devido à ausência de um princípio ao qual a consciência pudesse recorrer, por compreender que essa sempre busca um elemento exterior a si a fim de se estabelecer. O filósofo estaria a propor o retorno à consciência, buscando nela seu próprio fundamento, não ao modus de uma essência, mas na chave de uma consciência que cria a si mesma, gesto proposto por ele na obra Fundamentos da Doutrina da Ciência (1794). Nesta, o autor tentará rever a categoria do eu penso kantiano, modificando-a para um eu puro. Segundo Walter Jaeschke, essa orientação, vista em ambos os filósofos, traz o Eu (consciência de si) para o centro das discussões da filosofia transcendental, sendo o Eu pensado como "um sujeito que é atividade e que é constituído pela atividade" e não mais como "uma substância pronta para si e sem estrutura" (NOLASCO apud JAESCHKE, 2015, p. 13). 
Embora tenhamos apenas enunciado brevemente a relação do Romantismo e da Filosofia, tal sistema monista do Eu, tensionado frente ao dualismo kantiano (relação de fenômeno e coisa em-si), será considerado, com as devidas proporções, por grande parte dos movimentos que encontramos no século XVIII. Tal questão é vista, implicitamente, por exemplo, na tentativa de rearticulação dos dualismos, e das dialéticas e dos diálogos com a ideia de um elemento de unificação (espírito, absoluto) que suprimisse/unificasse as antinomias, antevista nos sistemas de Novalis e do trágico pela perspectiva de Schelling, Hegel e, também, Hölderlin. ${ }^{10}$

É importante salientar que os traços da filosofia kantiana ainda projetam sua sombra nos sistemas religiosos da época, na concepção de um retorno ao mundo do espírito. Além disso, se entrelaçam à centralidade que a ideia de sujeito passa a ocupar na literatura, especialmente no âmbito do romance alemão. Somado a essas características, cabe ainda destacar o relevo dos elementos simbólicos, autorreflexivos, religiosos, revolucionários, bem como o anti-heroísmo dos personagens vislumbrados em vários estilos literários em voga no Romantismo alemão. Pode-se dizer, assim, que tal movimento romântico, em suma,

[...] criou e rejuvenesceu gêneros literários desconhecidos, negligenciados ou decadentes: o lirismo, a poesia semilírica, semiépica das baladas, um teatro liberto das regras clássicas, seguindo a tradição de Shakespeare e procurando dar aos seus assuntos o quadro e a atmosfera autêntica da época, o romance histórico e o romance pessoal, psicológico, individualista, que fixa a vida íntima e a evolução das personagens. Encorajou e cultivou a poesia dialetal, dando forte impulso ao regionalismo ameaçado pela centralização moderna. Inspirou [...] os estudos históricos e

\footnotetext{
10 Utilizamos o termo dialética, nesse contexto, a partir da definição que nos oferece o Dicionário Filosófico de Nicola Abbagnano. Nesta obra, é explicitado que o termo dialética, que "deriva de diálogo", "[...] não foi empregado, na história da filosofia, com significado unívoco, que possa ser determinado e esclarecido uma vez por todas; recebeu significados diferentes, com diversas interrelações, sendo redutíveis uns aos outros ou a um significado comum. Todavia, é possível distinguir quatro significados fundamentais. São eles, [...] como método da divisão; lógica do provável; lógica; síntese dos opostos." $1^{a}$, 2a, $3^{a}$ e $4^{a}$ definições, respectivamente. Utilizamos, nesse momento, o termo dialética segundo seu $4^{a}$ significado. (ABBAGNANO, 2007, p. 269, s.v. 'Dialética').
} 
filológicos, por sua concepção mais veraz, mais viva e mais ampla do desenvolvimento [...] (AUERBACH, 2005, p. 355).

Buscamos, portanto, elucidar os aspectos mais significativos desses movimentos intelectuais e artísticos, de modo a demarcar a singularidade de cada um, sem deixarmos de refletir sobre a necessária modulação ao se analisarem as confluências que ocorrem no contexto de um século como o XVIII. É frequente que um movimento atravesse o outro e repita as teses que aparentemente vise a repudiar.

Feito o esclarecimento, após a pluralidade de influências apresentadas sobre o contexto, gostaríamos de destacar aquilo que, para além da filosofia (e tensionado também por ela) se encontra repetidamente na base das discussões desses movimentos e, por isso, antevista nos sistemas de poetas e filósofos da época: a presença da antiguidade ou a querela entre antigos e modernos, que será retomada, discutida, ressignificada e aprofundada ao longo de todo o século XVIII. Tal questão, notada nas obras dos poetas e de filósofos, está implicada nas observações da política, cultura, história e arte da antiguidade, fornecidas inicialmente por dois nomes de relevo: Winckelmann e Lessing. Sobre esse ponto, Marco Aurélio Werle destaca, inclusive, a influência dos intelectuais já no movimento Tempestade e ímpeto:

1. Em toda essa época, há uma crítica ao classicismo francês, ao domínio da literatura francesa, na medida em que esta encarnava as regras clássicas (Boileau); 2. Ao lado disso, apresenta-se uma busca pelo verdadeiro sentido dos antigos, sendo este tópico mais forte em Winckelmann, o grande descobridor da Antigüidade clássica, do que em qualquer outro. A estratégia comum era precisamente opor o autêntico Aristóteles (segundo se supunha) ao Aristóteles dos franceses (o modelar). Se bem que essa estratégia não se aplica tanto a Winckelmann, para quem a relação com a Antiguidade grega era mais plástica do que marcada pelos parâmetros da teoria da tragédia; 3 . Junto à defesa do sentido autêntico dos antigos vem a adoração a Shakespeare, bastante forte em Lessing e Herder. Neste caso, além de contrapor o pensador da tragédia antiga, o Aristóteles autêntico, ao classicismo francês, 
também se lhe opunha a excelência poética moderna. [...] 4. Outro ponto comum, mas também de diferença, e que é mais forte em Lessing, é a crítica ao regime absolutista e a defesa de uma cultura alemã própria baseada numa sociedade burguesa (WERLE, 2000, p. 25).

Assim, embora Winckelmann e Lessing tratem de aspectos diferentes da arte antiga, plástico, de um lado, e poético, de outro, seus escritos são responsáveis pela imagem e recepção que Schiller, Goethe, os irmãos Schlegel, Hölderlin, Schelling e Hegel terão da Antiguidade Clássica, especialmente no que se refere ao drama.

\subsection{Winckelmann e a imitação dos antigos}

O estudo e retomada dos antigos foi uma presença constante na Alemanha e em grande parte da Europa, devido à nostalgia do passado como ideal cultural. Contudo, é especialmente a partir de Johann Joachim Winckelmann (1717-1768), historiador e esteta alemão, que se coloca em perspectiva, pela primeira vez, a dimensão epocal da antiguidade. Tal feito é realizado mediante um viés teórico e histórico que Winckelmann propõe em suas reflexões. O período acima indicado era considerado, desde o Renascimento, como um bloco greco-romano uniforme. Todavia, o historiador foi responsável por refletir sobre as especificidades que acompanham cada povo no que se refere às obras de arte. Nesse caso, ao se observar um processo estético particular, outros elementos, para além da arte, são evidenciados nessa análise, tais como o ethos e a localização geográfica nas quais se cria. Fatores que, por sua vez, ampliariam a reflexão acerca das singularidades culturais.

Ao trabalhar essas questões, o que se nota é o redimensionamento da diferença, das antinomias entre antigos e modernos. Essa diferença é colocada a partir do esclarecimento acerca de um contexto de causas formativas de cada um desses povos, cujo resultado não estaria dissociado 
do resultado na esfera que propõe. Por este motivo, Winckelmann, é considerado o fundador da história da arte enquanto disciplina, mas também, segundo Gerd A. Bornheim, pelo "novo comportamento em face da arte" que consistiu em observar as obras de arte (neste caso, as obras de arte gregas) em sua concretude material, ${ }^{11}$ e não apenas como teoria e reflexão estéticas. Por isso, Winckelmann foi considerado o "precursor da moderna metodologia científica" nesse campo (BORNHEIM in: WINCKELMANN, 1961, p. 32).

Em sua obra mais extensa, História da Arte Antiga (1764), o historiador da arte alemão teoriza sobre o modo como ocorre o processo de surgimento da arte e da cultura na Antiguidade. Marco Aurélio Werle (2000, p. 26) destaca a importância desse escrito como um "dos monumentos de prosa clássica europeia", no qual o historiador forja sua visão "da Antiguidade Clássica".

Embora em sua obra sejam analisados os aspectos das culturas egípcias, etruscas e de outros povos, é possível notar que o autor se inclina a uma predileção pelos gregos por notar neles propriedades distintivas no que se refere a sua estrutura artística e a seus costumes. Tal destaque residiria, segundo Winckelmann, na singularidade helênica, vista, por exemplo, no enlace entre aspectos materiais (físicos) e imateriais (espirituais) somados ao âmbito de vivências daquele povo: a relação entre ambiente, clima, e a geografia do espaço; a concretude dos traços humanos e certa compleição inata que os gregos possuíam propensa à moral estoica, de modo que "[...] and the nearest we draw in the climate of Greece, the more beautiful, lofty, and vigorous is the conformation of man" (WINCKELMANN, 1880 [1764], p. 229).12 Nesse sentido, segundo o esteta, "[...] they have partly an air of nobleness, partly of acuteness and

\footnotetext{
${ }^{11}$ É importante mencionar que Winckelmann, teve a oportunidade de observar as obras de arte gregas (mesmo em cópias romanas) pessoalmente, pelo fato de ter sido o bibliotecário do Vaticano.

12 "quanto mais nos aproximamos do clima da Grécia, mais bela, elevada e vigorosa será a configuração do homem" (WINCKELMANN, 1880, p. 229).
} 
intelligence; and the form of the face is generally large and full, and the parts of it in harmony with each other". ${ }^{13}$ Assim como,

The superiority of conformation is so manifest, that the head of the humblest man among the people might be introduced in the most dignified historical painting, especially one in which aged men are to be presented. And among the woman of this class, even in places of the least importance, it would not be difficult to find a Juno. (WINCKELMANN, 1880 [1764], p. 230) ${ }^{14}$

Esses temas serão articulados em seu livro Reflexões sobre a imitação das obras gregas na pintura e na escultura (1755), em que o historiador elenca os motivos pelos quais a localização mediterrânea e a natureza de um "céu sereno" afinam-se a uma beleza já latente na forma física dos gregos, apenas sutilmente modelada pela prática dos exercícios corporais (WINCKELMANN, 1975 [1755], p. 41).

As análises sobre a matéria do corpo, da forma e dos contornos, sintetizadas por ele sob o nome natureza, funcionarão como o cenário de uma intensa reflexão em vistas a demarcar a anteposição entre antigos e modernos, e de modo a elucidar as especificidades encontradas no modo com que os gregos se apropriam de seu tempo e espaço. A partir dessas análises, Winckelmann concluirá que,

[...] na maioria das figuras dos mestres modernos, observam-se, nas partes comprimidas do corpo, pequenas dobras da pele demasiado marcadas; ao contrário, onde essas dobras se formam nas partes, igualmente comprimidas de figuras gregas, uma suave ondulação as faz surgir uma da outra, à maneira de ondas, de modo que parecem constituir um todo, e produzir uma única nobre pressão. A pele que nos mostram essa obras-primas não está esticada, mas levemente estendida sobre uma carne sadia, que a

\footnotetext{
13 [...] eles têm em parte um ar de nobreza, em parte perspicácia e inteligência; e a forma do rosto é geralmente ampla e cheia, e as partes dessa em harmonia umas com as outras" (WINCKELMANN, 1880 [1764], p. 230)

${ }_{14}$ A superioridade da configuração é tão manifesta, que a cabeça do mais humilde dentre os homens pode ser posicionada nas pinturas históricas mais dignificantes, especialmente aquelas nas quais homens de idade avançada serão apresentados. E dentre as mulheres de tal categoria, mesmo em posições de menor importância, não seria difícil encontrar uma Juno." (WINCKELMANN, 1880 [1764], p. 230)
} 
enche sem formar gorduras; ela acompanha os músculos e se une a eles, em todos os movimentos, cuja direção segue. Nunca a pele forma, como nos corpos dos nossos artistas modernos, pequenas dobras parciais, separadas da carne.

Parece naturalmente provável que na formação dos belos corpos gregos, como nas obras dos mestres antigos, havia mais unidade no conjunto de sua estrutura, uma mais nobre ligação das partes, uma plenitude mais acentuada, sem as tensões produzidas pela magreza, sem as concavidades e as depressões dos nossos corpos modernos. (WINCKELMANN, 1975 [1755], p. 46)

Tal crítica visa, segundo nosso entender, não apenas a elaboração da arte, mas toca os costumes dos modernos, considerados pelo historiador como um povo fragmentado, e não ideal. Winckelmann percebe na vestimenta e na representação artística grega um modelo de inspiração que orienta a viver uma relação livre e harmônica, com seu meio, buscando nele sua medida.

Assim, se é notada nos gregos uma liberdade e uma natureza auspiciosa, em um regime político apropriado, em que a vida civil não se opõe à liberdade, é esse mesmo elemento da vida que escapa aos contemporâneos do autor. Desse modo, ele sugere que:

O único meio de nos tornarmos grandes e, se possível, inimitáveis, é imitar os antigos; e o que se diz de Homero - que aprende a bem compreendê-lo quem aprende a admirá-lo - vale também para as obras de arte dos antigos, especialmente para as dos gregos. É necessário conhecê-las, como a um amigo, para considerar o Laocoonte tão inimitável como Homero. (WINCKELMANN, 1975 [1755], p. 39-40)

Tais reflexões, em nosso entendimento, não visam apenas a determinar o novo modo de se observar a arte grega, importante já no Renascimento, mas alçam os gregos ao paradigma inescapável aos modernos. 
A partir dessas proposições, Winckelmann estaria, nesse contexto, a tomar como base de suas reflexões uma das questões que atravessam a história da estética desde a antiguidade, a saber, a questão da mimesis aristotélica ou daquilo que se nomeia como a relação entre arte (tekhné) e natureza, a qual o historiador propõe por uma chave de leitura distintiva entre cópia e imitação. O primeiro desses conceitos é considerado um retrato, uma "imitação servil", uma vez que se concentra em partes aparentemente reais da natureza para produzir. Esse procedimento acarretaria o foco a elementos parciais, o que por sua vez desvirtua o real objetivo do fazer artístico: a representação do todo. Nesse caso, propõe o historiador como alternativa que o artista invista na perspectiva imitativa. Este segundo conceito é compreendido como a norma ideal, pois pressupõe a apreensão do todo que ocasiona, em última instancia, o surgimento do belo universal. Exclusivamente nesse âmbito de produção poderíamos nomear o trabalho artístico de criação.

Ainda no que se refere às distinções sobre os preceitos para a concretização do Belo, estaria implicada, de acordo com nosso entendimento, a percepção de que na fonte do pensamento heleno reside a reflexão profunda sobre um conjunto de leis ideais. Essas consistem em "regras implícitas" expostas nas singularidades da natureza e que compõem o "todo único", o modelo que se antevê na forma. Segundo Winckelmann, os princípios ou as "noções gerais", aqui tratadas como divinas, estariam a servir de medida, impondo-se, inclusive, à conformação da natureza (WINCKELMANN, 1975 [1755], p. 44-45).

Portanto, o processo artístico, fruto para ele da inspiração humana, estaria, por sua vez, subordinado a um princípio anterior, a uma ordem elevada. A genialidade, embora articulada pela sensibilidade, nesse caso, consistiria no uso da razão, apta a identificar e a ler as medidas gerais na natureza e a seguir esse preceito na produção, tal como o fez, por exemplo, 
o renascentista Rafael Sanzio (1483-1520), na criação de sua Galateia (WINCKELMANN, 1975 [1755], p. 45).

Esses indicativos apontam para certas forças formativas em jogo na relação do divino e o do humano, forças compreendidas, vividas e expressas no cotidiano grego em seu âmbito cultural e público. A experiência desse alvorecer, conforme sugere o historiador alemão, perdeu-se entre os modernos, uma vez que não apenas se encontra ausente certa apresentação da natureza, que mostrava tal ordem, mas porque o modo de compor artístico dos modernos não se subordina mais a tais preceitos. Para justificar esse raciocínio o autor censura a preferência barroca de sua época pelas obras de Gian Lorenzo Berníni (1598-1680), tidas pelos críticos como o espelho autêntico da Antiguidade. Para o esteta, neste caso, haveriam exageros e rebuscamentos na mão do escultor, apegado a minúcias. Pois neste caso, a orientação artística toma a si como referência (do singular) para compor, utilizando-se da fidedignidade da natureza real na reprodução. O resultado dessa dinâmica estaria consubstanciado em uma representação excessivamente humana, realista e amolecida, o que resulta, por sua vez, em um determinado desgaste da centelha divina, que corrompe a figuração. Para se antepor a esse antimodelo, Winckelmann recorre à estátua de mármore do grupo Laocoonte (140 a.C).

Uma das figuras mais famosas da antiguidade, a imagem representa a morte do sacerdote de Apolo, Laocoonte, e de seus filhos, devorados por duas víboras, episódio descrito por diversos autores da antiguidade, dentre eles, Homero e Virgílio. Winckelmann parte desta escultura para propor que se vê, na figura, o mínimo de intervenção humana na peça: o artista não expressa a intensidade do verossímil, que de fato teria ocorrido na morte violenta narrada no evento. Antes, se atem aos princípios do divino e da beleza, os quais lecionam que se extrai o mais nobre do humano, "a grandeza serena", diante da maior dor, de maneira sutil, porém. Conforme expõe Winckelmann: 
Laocoonte não profere gritos horríveis como aquele que Virgílio canta: a abertura da boca não o permite; é antes um gemido angustiado e oprimido, como Sadolet o descreve. A dor do corpo e a grandeza da alma estão repartidas com igual vigor em toda a estrutura da estátua e por assim dizer se equilibram. (WINCKELMANN, 1975 [1755], p. 53)

A reflexão nos parece denotar uma recomendação moral - elevar-se acima da própria natureza -, de modo a demarcar o status da superioridade divina face à condição humana. A discussão de Winckelmann sobre a estatuária de Laocoonte porta elementos de uma moral o que estoica, por perceber que grego, mesmo em face das maiores atribulações, mantém um semblante tranquilo e sereno (WINCKELMANN, 1975 [1755], p.53). Essa proposição é também estendida ao exame que o historiador realiza sobre o torso de Hércules e do Apolo do Belvedere, dentre outras obras de arte pictórica. A partir dessas análises, Winckelmann conclui que os gregos não investem na dor, mas na coragem, algo para ele perceptível a partir da representação. Do mesmo modo, os escultores helenos não intervêm diretamente na materialidade das obras. O fazer artístico, nesse caso, apenas supõe a lapidação, que mostra contornos da matéria, o que resulta em um equilíbrio (no sentido de se apossar) nas tensões impostas pela emoção, como visto acima no rosto e no corpo do Laocoonte.

Assim, na potência da arte, cuja finalidade é o belo, estaria também implicada uma questão pedagógica. Essa atividade não teria o gosto, a apreciação como finalidade exclusiva, mas também um viés diverso que pretende educar, propiciar ao observador um conjunto de exemplos sobre como ser, agir e pensar, de modo que "o conhecedor terá assunto para meditar e o simples amador aprender." (WINCKELMANN, 1975 [1755], p. 70). 
Por esse motivo, as implicações dessas teorias, conforme salienta Roberto Machado (2006, p. 09-10), marcam o nome de Winckelmann em sua época

[...] por ter sido o primeiro a dar ao classicismo alemão seu ideal estético, ao defender, em 1755 nas Reflexões, não só a superioridade da arte grega sobre a arte de todos os tempos, inclusive a romana, mas também a necessidade de imitá-la, duas ideias de grande futuro no que diz respeito à relação da Alemanha com a Antiguidade. Ele foi, assim, o primeiro de uma série de intelectuais e artistas alemães dominados pela "nostalgia da Grécia", isto é, em primeiro lugar, guiados pela concepção dos antigos como fundamentalmente os gregos - e não mais os romanos, como para os italianos renascentistas e os franceses clássicos - e, em segundo lugar, convencidos da importância dos gregos antigos para a constituição da própria Alemanha. (MACHADO, 2006, p. 13-14) (grifos nossos)

Assim, conforme salienta Marco Aurélio Werle, tais conjecturas teóricas do historiador de arte alemão foram encaradas pela literatura secundária como um tipo de classicismo, "com o que se entende que é preciso tomar o clássico como modelo: os gregos originais, o princípio da escultura especialmente e não as regras de Aristóteles apenas, tal como eram lidas pelo classicismo francês" (WERLE, 2000, p. 28). Ao mesmo tempo, a visão da Antiguidade de Winckelmann torna-se nesse contexto, um dos primeiros e mais efetivos momentos em que o neoclassicismo francês, o exagero barroco, são criticados em prol da economia, da clareza, e, por outro lado, o exagero na aferição de uma alma magnânima aos gregos. 15

\footnotetext{
15 Winckelmann, por sua vez, não foi o primeiro a postular o retorno aos gregos para substituir o classicismo francês, pois antes dele, já na primeira metade do século XVIII, os suíços Bodmer e Breitinger, e Johann Christian Gellert criticavam o excessivo zelo de Gottsched, então um dos maiores dramaturgos alemães, em vista dos franceses.
} 


\subsection{Lessing e a imagem do teatro grego}

Tão importante quanto as reflexões de Winckelmann sobre a arte no pensamento alemão acerca da antiguidade grega a partir da escultura e da pintura, é o pensamento do dramaturgo, poeta e crítico de arte Gotthold Ephraim Lessing (1729-1781). Suas elaborações sobre dramaturgia e poética, especialmente na Dramaturgia de Hamburgo (1769), oferecerão às teorias sobre os gêneros dramáticos contribuições significativas no que se refere à crítica, à tradução e à recepção da antiguidade pelos alemães.

\section{Em sua obra Laocoonte ou sobre as fronteiras da Pintura e} Poesia (1766), o dramaturgo posiciona a questão ut pictura poesis, ou seja, as diferenças entre a representação pictórica e textual. Nesse estudo, o autor toma como ponto de partida a escultura do grupo Laocoonte, sobre o qual medita a partir da retomada das percepções que Winckelmann havia desenvolvido em suas Reflexões. Em comum, concorda com esse último no que se refere à beleza como finalidade artística entre os gregos, a respeito de leis (elevadas) aplicadas ao modo de se compor, bem como em relação à preeminência dos gregos face aos modernos. Entretanto, Lessing recusa a supressão da emoção, contrapondo-se, assim, ao historiador, na medida em que lê na Antiguidade o aceno para a vivência e a celebração do sentimento:

Apenas no que toca ao motivo que o senhor Winckelmann atribui a essa sabedoria, na universalidade da regra que ele deriva a partir desse motivo, eu ouso ser de uma outra opinião. (LESSING, 2011 $[1766]$, p. 86)

Quando Homero conduz para a batalha os troianos com gritos selvagens e, em contrapartida, os gregos em resoluta quietude, os intérpretes notam com razão que o poeta desse modo quer expor aqueles como bárbaros e estes como um povo com moral. (LESSING, 2011 [1766], p. 87) 
Nos trechos acima, destaca-se que o recurso a uma determinada quietude grega, teria sido utilizado apenas como estratagema metafórico na literatura a fim de expressar os aspectos morais implicados na narrativa e não para determinar a impassividade como o traço distintivo daquele povo. Para elucidar tal hipótese, Lessing, evoca todo um conjunto de obras da poética clássica, contrapondo-se textualmente as escolhas escultóricas de Winckelmann, de modo a demarcar que os gregos são marcados por um páthos, pelo sentimento. Essa hipótese é demonstrada a partir da análise de eventos desenvolvidas na Ilíada. O crítico recupera, no poema épico, um evento em que se vê uma trégua na qual aos exércitos é concedido o direito de cremação dos corpos mortos em combate. Neste episódio, Príamo, proíbe seus troianos de chorarem, enquanto Agamenon age de modo diametralmente oposto em relação aos gregos. Para Lessing,

\begin{abstract}
Ele quer nos ensinar que apenas o grego com a sua moral pode chorar e ser corajoso ao mesmo tempo; por outro lado o troiano sem moral, para sê-lo, antes deveria sufocar toda humanidade.

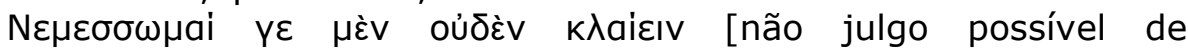
censura/quem chora], ele permite que o ponderado filho do sábio Nestor o profira num outro ponto. (LESSING, 2011 [1766], p. 87)
\end{abstract}

A emoção, a paixão ativa, vista como irascível e desmedida, característica que Lessing associa aos helenos, estaria suprimida na leitura winckelmaniana, que derivou a superioridade grega na base de uma "calma serena", em um equilíbrio de emoções. Lessing, por sua vez, notará uma tensão no interior dos personagens, carregados de uma dualidade, idealizada e homérica, de um lado, e opostamente humana, de outro, quando se trata da expressão dos sentimentos (LESSING, 2011 [1766], p. 86). Esse traço também é notado pelo dramaturgo nas peças de Sófocles, pois

Mesmo um Laocoonte encontra-se entre as peças perdidas de Sófocles. Se o destino nos tivesse concedido, sim, também esse Laocoonte! A partir das breves menções que alguns dos gramáticos 
antigos fizeram a ele, não se pode concluir como o poeta tratou a sua matéria. De uma coisa eu estou certo, que ele não teria exposto o seu Laocoonte mais estoico que Filoctetes e Hércules. Todo estoico é não teatral; e a nossa compaixão é sempre proporcional ao sofrimento que o objeto de interesse manifesta. Se nós o vemos suportar a sua miséria com grande alma, então essa grande alma irá decerto despertar nossa admiração, mas a admiração é um afeto frio, cujo maravilhar desprovido de atividade exclui qualquer outra paixão mais quente, bem como qualquer outra representação distinta. (LESSING, 2011 [1766], p. 88)

O dramaturgo escreve nesta mesma obra um longo ensaio sobre as principais características e diferenças entre as artes visuais ou pictóricas e as artes verbais, demonstrando que Winckelmann, além de se apoiar em argumentos frágeis quanto ao espírito grego em face do sofrimento, ainda havia ignorado o tipo de medium, ou material a ser usado. No caso das artes visuais e verbais, a principal diferença encontra-se na temporalidade e no recorte do acontecimento representado. Enquanto a estátua representa a cena simultaneamente, de uma só vez, o poeta a representa consecutivamente, uma parte após a outra. Por essa razão, ainda segundo Lessing, o artista que esculpiu o Laocoonte precisou fazer um recorte do acontecimento singular, de modo a deixar para a imaginação do receptor a complementação. Neste caso, nota-se que se Winckelmann parte da escultura, da poesia e da pintura, retirando de suas reflexões um ethos grego que parecia suprimir a emoção, Lessing, por sua vez, se concentrará na poética, especialmente no drama, para rearticular tal emoção em uma dinâmica contrária a seu contemporâneo.

Inicialmente, o crítico retomará a necessidade de um teatro nacional, antes pretendido por Johann Christoph Gottsched (1700-1766), que possuísse uma origem identitária própria, não mais mediada pela recepção da Antiguidade pelos franceses, pois, segundo Lessing, 
segundo as regras dos antigos. Todavia, o preconceito não se podia impor sempre, contrariando os nossos sentimentos. Felizmente, estes foram despertados por algumas peças inglesas, e descobrimos assim que a tragédia é capaz de produzir um efeito muito diferente do que o que CORNEILLE e RACINE foram capazes de the atribuir. (LESSING, 2005 [1767-1769], p. 180)

No trecho acima, vemos que a crítica lessinguiana ao teatro francês se refere à recepção e tradução do universo antigo, lido, segundo suas impressões, por uma ótica mecanicista, estática e excessivamente formal. Tal crítica se refere especialmente a Pierre Corneille (1606-1684) e a Jean Baptiste Racine (1639-1699). Ambos teriam proposto interpretações daquilo que se convencionou nomear no período como as "regras" da poética aristotélica, que se relacionam às três unidades e à finalidade da catarse. Além disso, os dramaturgos franceses citados teriam destacado um tom moral cuja tragédia teria como fim. Para o dramaturgo alemão, todavia, a França interpretou "erradamente as regras do drama da Antiguidade [...]" (LESSING, 2005 [1767-1769], p. 180-181). Lessing tem em vista, assim como Wincklemann, o encontro a uma atmosfera do período, uma aura grega, que ultrapassaria o mero acompanhamento das orientações textuais, que conformaria a base de uma visão estática das regras de composição.

O enfrentamento dessas teses será desenvolvido no interior de sua obra Dramaturgia de Hamburgo (1767-1769), que tem como fito refletir sobre a recepção das regras poéticas do período, vislumbradas na recorrência à Poética de Aristóteles, inescapáveis aos estudiosos europeus do período, que enfrentam, em maior ou menor medida, essa leitura tradicional:

O que me garante, pois, que não me aconteceu isto, que não interpreto mal a essência da arte poética dramática, é o facto de que eu a reconheço tal como ARISTÓTELES a abstraiu das inúmeras obras primas do teatro grego. Recebi deste filósofo as minhas ideias acerca da origem, das bases da arte poética, que não podia exprimir aqui sem me alargar. No entanto, não hesito em confessar (mesmo 
que nestes tempos esclarecidos se riam de mim por isso) que considero a sua obra tão infalível como os Elementos de EUCLIDES. Os seus princípios são igualmente verdadeiros e certos, só que não são tão compreensíveis e, por isso, mais sujeitos a mal-entendidos do que tudo sobre o que aqueles discorrem. Em especial, atrevo-me a provar irrefutavelmente no que respeita à tragédia, acerca da qual o tempo nos quis proporcionar mais ou menos de tudo, que esta não se pode afastar nem um passo que seja da norma de ARISTÓTELES sem se afastar outro tanto da perfeição. (LESSING, 2005 [1767-1769], p. 179)

Devido à presença aristotélica mediada por diversos textos teóricos do contexto é que Roberto Machado (2006. p. 38) nomeia os precedentes dramatúrgicos alemães da época como uma "verdadeira poética do teatro, de inspiração aristotélica". Interpretando a reflexão trágica a partir do pensamento de Aristóteles (articulada a seu modo), Lessing compreende o tema da mimesis sob uma base da verossimilhança, ou seja, na correspondência entre ação e sua efetiva representação na composição dramática. Tal fato resulta, segundo Machado, na especificidade do dramaturgo ter procurado "a verdadeira posição a respeito da poesia e a estabelecer os princípios da tragédia grega" (MACHADO, 2006, p. 37) em contraposição à Corneille, por exemplo.

Outro aspecto a ser salientado nas interpretações de Lessing é a análise da finalidade da catarse, tensionando o estudo dos efeitos do drama e debruçando-se, portanto, especialmente na articulação do capítulo XVIII da Poética aristotélica. A partir de suas proposições, é indicada pelo dramaturgo a mudança interpretativa da catarse, de terror e compaixão, para temor e compaixão. A fundamentação dessa conversão, segundo Marco Aurélio Werle, seria orientada por Lessing a partir da percepção de que "uma vez que o temor se dá entre homens que são iguais [...] o terror implica a existência de príncipes e reis, remetendo ao despotismo e à tirania" (WERLE, 2000, p. 36). Tal efeito teria o condão de aproximar o autor dramático dos espectadores, a partir da emoção que busca imprimir 
nos mesmos (WERLE, 2000, p. 36), uma necessidade do teatro da época que visava atingir uma burguesia nascente.

Assim, o argumento que se depreende dessas leituras visa propor não apenas uma leitura diversa sobre a literatura e a arte, mas também refletir sobre a necessária oposição ao elitismo, visto especialmente na arte teatral e na estrutura política engessada da época. Nesse mesmo sentido, novamente indica Marco Aurélio Werle, que, por essa razão, o foco de enfrentamento passa a ser o teatro aristocrático, considerado artificial e excessivamente normativo segundo Lessing, mediante a apreciação dos trabalhos de Corneille e Racine, que apresentavam boa recepção em solo germânico.

Tais reflexões tocam de maneira profunda não só o âmbito de uma estética mais geral, que opera no campo das diferenças entre arte figurativa e arte poética (Cf. LESSING, 1991), a qual ele critica como nenhum outro teórico da época. Mas também explicam o lugar que a dramaturgia passa a ocupar dentro dos estudos do gênero que está na base de suas reflexões.

Desse modo, o que se depreende do pensamento de Lessing, segundo a leitura de Werle (2000), é um projeto crítico de vital importância para os alemães, pois, com ele, "dá-se um início de rompimento substancial com as estéticas normativas", projeto que, sinteticamente, consiste em "opor Aristóteles aos franceses", ressaltando "o papel da catarse", ou seja, oferecendo uma nova interpretação do estagirita. Além disso, outro ponto importante reside no fato de Lessing, "tal como fará Herder, [caracterizar] o autor de teatro enquanto gênio (Shakespeare), aquele que não se atém às regras e que fala diretamente à alma do espectador" (WERLE, 2000, p. 36).

Aliada a essa ressignificação do ideário poético aristotélico, Lessing estaria a evidenciar as possibilidades filosóficas da tragédia, pois esta, segundo Wilhelm Dilthey (1922 [1907], p. 57), nos coloca "[...] uns in die 
Mitte der Bedingungen eines tragischen Charakters und in die Genesis seiner Leidenschaft versetzen". ${ }^{16}$ A partir dessa proposição é que Dilthey indicará que Lessing estaria diante de "[...] einer Reihe der wichtigsten Wahrheiten über das Verhältnis von Poesie, Philosophie und Geschichte" (DILTHEY, 1922 [1907], p. 57). ${ }^{17}$ Tal verdade é a diferença entre poesia e história, já colocada por Aristóteles, entre um certo tipo de possível da ação humana em "certas circunstâncias", plasmado na poesia, e um comportamento "real e necessário", verificado na história. Assim, Lessing teria compreendido, de forma mais próxima ao texto do estagirita, que a essência da poesia seria "a ação", mas somente a ação que se expõe "num caráter humano e verdadeiro, no movimento livre de suas paixões" (DILTHEY, 1922 [1907], p. 57).

Diante do plano geral apresentado até o momento podemos nos perguntar quão influentes foram as teorias de Winckelmann e Lessing, para a recepção dos gregos entre os alemães do século XVIII em diante. As contribuições de ambos, em nossos entender, consistem em terem apresentado a importância da Antiguidade grega e por terem evidenciado certa ambiguidade presente naquele contexto. Notadamente, percebe-se tal questão quando temos em vista a leitura empreendida por Lessing da escultura de Laocoonte, que o dramaturgo mobiliza para "distinguir o princípio da escultura e poesia, e de onde parte Winckelman para explicitar somente o ideal grego" (WERLE, 2000, p. 42). Uma proposta que sintetiza a visão dos clássicos que se faz notar nas produções literárias e nas reflexões filosóficas da época. ${ }^{18}$

\footnotetext{
16 "A Tragégia nos coloca no meio das condições de um personagem [ou caráter ou personalidade] trágico e na gênese de sua paixão." (DILTHEY, 1922 [1907], p. 57)

17 "Lessing estaria diante de uma das verdades mais importantes que envolvem filosofia, poesia e história." (DILTHEY, 1922 [1907], p.57)

${ }^{18}$ Acerca disso, é possível notar certa preferência pelos autores do período pela escultura e pela tragédia enquanto espaços de reflexão. No caso da Filosofia, isso se expressa, especialmente, nos textos estéticos de Schelling e Hegel. Quais seriam os motivos dessa predileção? A nosso ver, isso se refere a influência que Winckelmann e Lessing imprimiram sobre seus leitores, uma vez que, como visto neste artigo, a escultura e a tragédia foram as obras de arte elegidas por eles, para tematizar suas reflexões acerca da antiguidade.
} 


\section{Considerações finais}

Conforme proposto, refletimos sobre a possibilidade de estudos conexos entre o contexto histórico, literário e filosófico da Alemanha, de modo a perquirir a circulação de algumas ideias no contexto europeu do século XVIII. O motivo dessa proposta residiu no fato de que essas reflexões possibilitaram a construção da cultura e do pensamento dos germanos, que propomos pelo recuo até os fundamentos desse período de raízes muito profundas, advindas de um intenso embate e intercâmbio de ideias que se alastra por toda a Europa daquele século.

Cabe, porém, um esclarecimento de ordem metodológica. Uma das dificuldades que se colocam ao pesquisador que tenta sintetizar o período que abarca do pré-Romantismo ao Idealismo e ao Romantismo alemão, consiste na delimitação dos traços característicos que fundamentam tendências de pensamento tão "opostas" entre si. Como propõe Nicolai Hartmann (1983, p.189), ao discorrer, por exemplo, acerca da definição do Romantismo nos campos da filosofia e da poesia, "toda a definição se torna um ponto de partida discutível". Em direção similar, Michael Löwy e Robert Sayre (2015, p. 23) argumentam, em sua tentativa de redefinição do período, que cada autor "tem sua própria escolha e às vezes revisa sua escolha anterior em prol de outra lista".

Assim, diante da dificuldade de circunscrever e sistematizar os elementos distintivos de um contexto cultural em efervescência, como a passagem do século XVIII ao século XIX. Sobretudo o que tange ao universo do pensamento alemão, coloca-se em pauta uma questão (e uma necessária precaução): as limitações que o anseio de completude e totalidade, a "ânsia de infinito", própria aos idealistas e aos românticos, colocadas à compreensão e à percepção críticas do analista ao tratar tais 
fenômenos culturais. Diante disso, optamos, nesse artigo, por apresentar um panorama das sínteses propostas por Otto Maria Carpeaux (1963), Massaud Moisés (1978), Marco Aurélio Werle (2000), Erich Auerbach (2005), Michael Löwy e Robert Sayre (2015) e Constantino Luz de Medeiros (2018). Com isso, visamos a destacar o aspecto multifacetário dos movimentos artísticos, filosóficos e políticos que convulsionam e transformam a Europa do século XVIII e início do XIX, a saber:

[...] sua natureza de coincidentia oppositorum: ao mesmo tempo (ou alternadamente) revolucionário e contrarrevolucionário, individualista e comunitário, cosmopolita e nacionalista, realista e fantástico, retrógrado e utopista, revoltado e melancólico, democrático e aristocrático, ativista e contemplativo, republicano e monarquista. (LÖWY; SAYRE, 2015, p. 19)

Desse modo, tendo em mente a diversidade de articulações e combinações possíveis dessas perspectivas divergentes, tentamos apresentar uma percepção que não se quer um entendimento simplista ou mecânico das tendências de pensamento acima. Antes, atentos à complexidade das relações entre eles, buscamos respaldar nossa compreensão no comentário de Theodor Ludwig Wiesengrund-Adorno (2013, p. 301), para quem esse contexto (do Sturm und Drang/préromantismo ao Idealismo alemão) consiste na coexistência e justaposição de um "éter dos pensamentos". A terminologia retirada da obra hegeliana por Adorno, parece-nos apropriada para um contexto no qual limites entre tendências e formas de pensamento se tornam discutíveis, em vista das inúmeras convergências e afastamentos simultâneos notados. 


\section{REFERÊNCIAS}

ABBAGNANO, N.. Dicionário de Filosofia. Trad. Alfredo Bosi. São Paulo: Martins Fontes, 2007.

ADORNO, T. W. Três estudos sobre Hegel. Trad. Ulisses Razzante Vaccari. São Paulo: Editora Unesp, 2013. AUERBACH, E.. Introdução aos estudos literários. Trad. José Paulo Paes. São Paulo: Cosac Naify, 2005. BERGSON, H.. A filosofia francesa. In: Trans/Form/Ação, Marília, v. 29, n. 2, p. 257-271, 2006. Disponível em: <http://www.scielo.br/scielo.php?script=sci_arttext\&pid=S0101-31732006000200018\&lng=en\&nrm=iso>. Acesso em: 13 jun. 2019.

BERTAUX, P.. Hölderlin und di Französische Revolution. Frankfurt/M: Editora 1969.

BOLD, V.. Ossian and James Macpherson. In: Fazzini, M. (Ed.) Alba Literaria: A History of Scottish Literature. Series: Calibano (8). Venice: Amos Edizioni, 2005. p. 193 -204.

CARPEAUX, O. M.. História da literatura alemã. São Paulo: Cultrix, 1963.

COSTA, D. T.. Friedrich Hölderlin: a sobredeterminação política do estético na construção do cânone enquanto gesto tributário da recepção. 127 f. (Mestrado em Estudos Literários). Faculdade de Letras, Universidade Federal de Minas Gerais, Belo $2008 . \quad$ Disponível em: <http://www.bibliotecadigital.ufmg.br/dspace/handle/1843/ECAP-7KUH97>. Acesso em: 04 ago. 2019.

DILTHEY, W.. Poética. Trad. Elsa Tabernig. Buenos Aires: Losada, 2007.

GALÉ, P. F.. Winckelmann: uma história da arte entre a norma e a forma. 2016. Tese (Doutorado em Filosofia). Faculdade de Filosofia, Letras e Ciências Humanas, Universidade de São Paulo, São Paulo, 2016. Disponível em $<$ https://www.teses.usp.br/teses/disponiveis/8/8133/tde-24112016124755/publico/2016_PedroFernandesGale_VCorr.pdf> Acesso em: 09 set. 2020.

GASKILL, P. H. Hölderlin's Contact with Pietism. In: The Modern Language Review. v. 69, n. 4, oct. 1974, p. 805-820. Disponível

em: <https://www.jstor.org/stable/3725294?readnow=1\&refreqid=excelsior\%3A5d87b7b7577edf43b4ac1daa3321b f51\&seq=4\#page_scan_tab_contents> Acesso em: 01 ago. 2019.

HARTMANN, N.. A filosofia do idealismo alemão. Trad. José Gonçalves Belo. 2.ed. Lisboa: Fundação Calouste Gulbenkian, 1983.

HÖLDERLIN, F.. Correspondência completa. Trad. Helena Cortés Gabaudan; Arturo Leyte Coelho. Madrid: Hiperión, 1990.

LESSING, G. E.. Dramaturgia de Hamburgo: selecção antológica. Trad. Manuela Nunes. Lisboa: Fundação Calouste Gulbenkian, 2005.

LESSING, G. E.. De teatro e literatura. Introdução e notas Anatol Rosenfeld. São Paulo: EPU,1991.

LESSING, G. E.. LAOCOONTE ou sobre as fronteiras da pintura e da poesia: com esclarecimentos ocasionais sobre diferentes pontos da história da arte antiga. Trad. Márcio Seligmann-Silva. São Paulo: Iluminuras, 2011. LÖWY, M.; SAYRE, R.. Revolta e melancolia: o romantismo na contracorrente da modernidade. Trad. Nair Fonseca. São Paulo: Boitempo, 2015.

MACHADO, R.. O nascimento do trágico: de Schiller a Nietzsche. Rio de Janeiro: Jorge Zahar Ed., 2006.

MEDEIROS, C. L. de. A invenção da modernidade literária: Friedrich Schlegel e o romantismo alemão. 1. ed. São Paulo: Iluminuras; Belo Horizonte: Editora UFMG, 2018.

MOISÉS, M.. Dicionário de termos literários. 2. ed. São Paulo: Cultrix,1978.

NOLASCO, F. M.. A suspensão qualitativa da quantidade: a crítica de Hegel ao paradigma matemático da ciência moderna. 496 f. (Doutorado em Filosofia). Universidade Estadual de Campinas, Campinas, 2015. Disponível $\quad$ em: <http://repositorio.unicamp.br/bitstream/REPOSIP/281203/1/Nolasco_FabioMascarenhas_D.pdf>. Acesso em: 08 jul. 2019.

ROUSSEAU, J.-J.. Textos filosóficos: seleção de textos. Trad. Lúcia Pereira de Souza. São Paulo: Paz e Terra, 2002.

SUAREZ, R.. Nota sobre o conceito de Bildung (formação cultural). In: Kriterion, Belo Horizonte, v. 46, n. 112, p. 191-198, dez. 2005. Disponível em: <http://www.scielo.br/scielo.php?script=sci_arttext\&pid=S0100512X2005000200005\&lng=en\&nrm=iso>. Acesso em: 15 mar. 2021.

VACCARI, U. R.. A via excêntrica: Hölderlin e o projeto de uma nova estética. 186 f. (Doutorado em Filosofia). Universidade de São Paulo, São Paulo, 2012. Disponível em: <http://www.teses.usp.br/teses/disponiveis/8/8133/tde-13092012-110401/pt-br.php>. Acesso em: 02 jul. 2019.

WELLEK, R.; WARREN, A.. Teoría Literaria. 4. ed. Madrid: Gredos, 1966 (5a Reimpressão de 1985).

WERLE, M. A.. Winckelmann, Lessing e Herder: estéticas do efeito? In: Trans/Form/Ação [online], Marília/SP, v. 23, n.2000, p. 19-50, 2000. Disponível <http://www2.marilia.unesp.br/revistas/index.php/transformacao/article/view/812/707>. Acesso em: 22 dez. 2019.

WERLE, M. A.. Hölderlin: intuição e intimidade. In: Ide (São Paulo), v. 34, n. 53. São Paulo, dez. 2011. Disponível em: http://pepsic.bvsalud.org/scielo.php?script=sci_arttext\&pid=S0101-31062011000200018 . Acesso em: 14 ago. 2020. 
WERLE, M. A.. Hölderlin e Hegel: a afirmação trágica e filosófica do idealismo. In: $\mathbf{O}$ que nos faz pensar, v. 24, n. 36. p.315-327, 2015. Disponível em http://oquenosfazpensar.fil.pucrio.br/import/pdf_articles/OQNFP_36_16_marco_aurelio_werle.pdf> Acesso em: 10 set. 2020.

WINCKELMANN, J. J.. Reflexões sobre a arte antiga. Trad. Herbert Caro e Leonardo Tochtrop. 2. ed. Porto Alegre: Movimento, 1975.

WINCKELMANN, J. J.. The history of ancient art. Trad. G. Henry Lodge. Vol.1. Boston: James R. Osgoog, 1880. 


\section{DESCOMPASSOS COMBINADOS: ASPECTOS DA FICÇÃO DE MURILO RUBIÃO}

Resumo: Este trabalho consiste em uma leitura exploratória dos contos de Murilo Rubião a partir do levantamento das imagens de espaço, tempo e sujeito ficcionais que conformam seu imaginário narrativo. Procura-se observar como a percepção da realidade, proposta pelo olhar literário rubiano ocorre, por meio da desestabilização das referências espaçotemporais, que oscilam entre as racionalidades e valores do arcaico e do moderno, configurando, assim, uma realidade ficcional regida por uma lógica da incerteza. Para tanto, são articulados os apontamentos de Italo Calvino a respeito da relação entre realidade e fiç̧ão na literatura fantástica; as reflexões de Luis Alberto Brandão acerca das categorias de sujeito, espaço e tempo no âmbito do texto literário; a leitura de Antonio Candido sobre a síntese de temporalidades contraditórias que constitui a realidade social brasileira.

Palavras-chave: Murilo Rubião. Literatura fantástica. Sujeito. Espaço. Tempo.

\section{Introdução}

Para o leitor, o mundo de Murilo não é e é o seu mundo. (David Arrigucci Jr., Minas Gerais, assombros e anedotas)

${ }^{19}$ Currículo Lattes: http://lattes.cnpq.br/8507603800115505. 
[...] os antagonismos não resolvidos da realidade retornam às obras de arte como problemas imanentes da sua forma. (Theodor Adorno, Teoria Estética)

Vários olhares críticos já se voltaram para a produção literária de Murilo Rubião. Na tentativa de compreender a obra do escritor mineiro, que tem início em 1947, com a publicação de 0 ex-mágico, a crítica literária brasileira buscou enumerar os aspectos e traços característicos de seus contos.

A ausência de narrativas precedentes com características "desrealizantes", como os contos de Murilo Rubião, coloca sua obra em um local atópico ${ }^{20}$ na história da literatura brasileira, como se pode confirmar em obras e textos dedicados ao mapeamento do conto brasileiro. ${ }^{21}$ Tal aspecto ocasionou que, nos quase 80 anos de leituras, a ficção rubiana fosse associada a três tradições marcadas pela problematização da ideia de realismo: o gênero denominado realismo fantástico, tendo como parâmetro as narrativas de Edgar Allan Poe e Ernst Theodor Amadeus Hoffmann; o realismo maravilhoso das ficções latino-americanas de Gabriel García Márquez, Jorge Luis Borges e Julio Cortázar; às ficções do absurdo, de Henry James e Franz Kafka, marcadas pela ocorrência de fatos incomuns em circunstâncias do dia a dia, como um indivíduo acordar transformado em um inseto ou ser acusado de um crime inexistente.

Em comum, essas três famílias narrativas apresentam a problematização realismo versus fantástico, ou seja, contrapõem o real

\footnotetext{
20 Maria Esther Maciel, em artigo intitulado "Poéticas do inclassificável" (MACIEL, 2007), parte de uma reflexão sobre os significados da palavra topos (lugar e discurso) e de sua expansão, o atopos, para discutir o conceito de inclassificável - compreendido como "o que não se confina a um lugar, o que resiste à definição, à descrição" (MACIEL, 2007, p.155). A partir dessa reflexão, proponho que consideremos os contos de Murilo Rubião como narrativas atópicas - característica que, a meu ver, pode ser atribuída à obra muriliana, a fim de demarcar sua "ausência de foro" no campo literário.

${ }^{21}$ Em BOSI (2008), BRASIL (1975), CAMPOS (1977), LIMA (1983), LUCAS (1983) e XAVIER (1987), observa-se a tentativa de estabelecer uma tradição literária à qual a linguagem de Murilo Rubião se filiaria. Esta "linhagem" de precursores comporta autores como Machado de Assis, Aluísio Azevedo, Afonso Arinos, Monteiro Lobato, Cornélio Penna, Aníbal Machado e, recentemente, alude-se à proximidade de sua obra com o "surrealismo" de alguns romances de Rosário Fusco.
} 
cotidiano à irrealidade manifesta na ficção. Para demonstrar como ocorre essa oposição, tomam como ponto de partida o que se convencionou chamar de efeito de estranhamento. Este seria provocado pela contradição entre, por um lado, o caráter absurdo dos acontecimentos e enredos dos contos e, por outro, pela clareza e simplicidade da linguagem usada para a elaboração das narrativas. Diante dessa incongruência, o leitor se vê hesitante em relação aos fatos expostos, ao mesmo tempo estranhos e sem nexo, mas narrados a partir de uma linguagem coerente e situações familiares, que tornam as narrativas compreensíveis e aceitáveis ou verossímeis.

Assim, tendo em vista esse panorama, o que se propõe neste texto é observar como Murilo Rubião configura a realidade apresentada em sua estética literária. Compreenda-se, contudo, que "não se trata de uma realidade dada de antemão, que a literatura estaria a expor, mas sim de uma realidade que é exposta na literatura".22 Como balizas para nortear este trabalho de exploração, partimos das seguintes questões: que imagens de espaço, tempo e sujeitos ficcionais a obra de Rubião apresenta e problematiza? Como esses elementos atuam na configuração do mundo ficcional exposto nas narrativas de Rubião? Que valores (arcaico, moderno, rural, urbano, perenidade, transformação) se encontram veiculados e questionados nessas imagens de mundo e de homem?

Dessa maneira, para desdobrar as epígrafes de Davi Arrigucci Júnior e Adorno, buscamos apresentar elementos presentes nos contos rubianos que auxiliem a perceber o que Antonio Candido chama de redução estrutural ${ }^{23}$ ou, em outros termos, "como o recado do escritor se constrói a partir do mundo, mas gera um mundo novo, cujas leis fazem sentir melhor a realidade originária". (CANDIDO apud WAIZBORT, 2007, p. 241) Para

\footnotetext{
22 Observação interposta sobre o desalinho de Machado de Assis (WAIZBORT, 2007, p. 239).

23 Termo empregado por Antonio Candido que designa o processo de mediação pelo qual se dá a transformação da sociedade em texto. (Cf. CANDIDO apud WAIZBORT, 2007, p. 247).
} 
tanto, sugerimos, a partir de alguns contos de Rubião, uma possível correlação entre a linguagem literária do autor e os processos sociais brasileiros. Como hipótese, propomos que a obra do escritor mineiro se mostra não apenas como um discurso ficcional sobre a realidade, mas como uma leitura que coloca em perspectiva as contradições do Brasil ao transfigurá-las em forma literária.

Para fundamentar estas reflexões, recorremos a formulações da sociologia da literatura e da teoria da literatura. A partir do trabalho de Luis Alberto Brandão Santos, apresentamos considerações acerca das categorias de sujeito, espaço e tempo no âmbito do texto literário. A seguir, expomos como, a partir dessas, organizam-se os mecanismos atuantes na reelaboração da realidade social e em discurso ficcional. No que concerne à conceituação da literatura fantástica, recorremos à caracterização feita por Ítalo Calvino. Por fim, para refletir acerca das temporalidades manifestas nos contos de Rubião, recorremos à leitura de Antonio Candido (CANDIDO, 1995) sobre Raízes do Brasil, de Sérgio Buarque de Holanda, em que se expõe a metodologia dos contrários, ou jogo dialético, para embasar a reflexão sobre o processo sócio-histórico brasileiro. Com isso, buscamos apresentar como o efeito fantástico ocorre a partir do descompasso entre a percepção das personagens (sujeitos da história) e a temporalidade das narrativas, visando a demonstrar como esses aspectos atuam na configuração da realidade ficcional rubiana, regida por uma lógica da incerteza.

\section{Sujeito, espaço e tempo: coordenadas do texto narrativo}

Sujeito, espaço e tempo são noções presentes em nosso cotidiano. Todavia, por serem termos tão familiares, pouco nos perguntamos como organizam nossa percepção e conhecimento de mundo. Com isso, 
queremos dizer que não são conceitos autoexplicativos, de conhecimento compartilhado por todos. Antes, são o "óbvio", ou seja, aquilo que escapa à compreensão e que não sabemos definir de imediato. Tente, por exemplo, perguntar a alguém o que são o sujeito, o espaço e o tempo ou, ainda, como funcionam para descrever e conhecer os mundos real e literário. Desse modo, compreendidas como imagens do mundo, ${ }^{24}$ as noções de sujeito, espaço e tempo estruturam os sistemas de referências que usamos para perceber as realidades intra e extratextuais, ou seja, dos mundos dentro e fora dos livros.

Sendo assim, investigar o funcionamento de tais categorias na organização de um texto ficcional implica no levantamento de questões como: quando se fala sobre sujeito, espaço e tempo em textos literários, o que se quer dizer? Seriam referências a categorias que apenas evocam imagens do mundo representado pela literatura? Ou podemos dizer que as representações literárias, ao citarem estes discursos que configuram um modo de ver o mundo em dada época, suscitam outras perspectivas e abordagens das representações (ficcionais e científicas) da realidade? A partir destas indagações, buscamos compreender como as categorias mencionadas são responsáveis por estabelecer as coordenadas de produção de sentidos em representações textuais, permitindo-nos, assim, ler uma obra ficcional como sendo "mais real ou mais irreal".

Nesse sentido, hipótese relevante é que as concepções de sujeito, de espaço e de tempo funcionam como determinações configuradoras da natureza realista da narrativa literária. De acordo com esse princípio, a correlação entre os três termos fundamentaria a percepção das situações apresentadas no texto ficcional como sendo experiências cognoscíveis, ou seja,

\footnotetext{
24 Por imagens do mundo compreendem-se as "constelações de ideias segundo as quais diferentes sociedades humanas fundamentam, tanto coletiva quanto individualmente, a experiência do existir. [Em síntese, são o conjunto] das categorias pelas quais a cultura ocidental compreenderá a realidade e atuará sobre ela". (OLIVEIRA, 2003. p. 33).
} 
[...] toda narrativa, para ser percebida como tal, pressupõe pelo menos três categorias: tempo, espaço e sujeito. [...] Pode-se falar, assim, que toda narrativa é caracterizada por uma duração, uma localização e uma voz; ou que o movimento narrativo se efetua quando há uma conjugação dos verbos transcorrer, estar e ser. (BRANDÃO, 2002, p. 182) (grifos meus)

Tal formulação indica, então, que as convenções que afiançam legibilidade às referências presentes em uma narrativa ficcional são pautadas pela correlação entre um sujeito/voz/olhar, um espaço/localização e um tempo/duração. Das relações entre esses elementos, estabelecem-se as coordenadas que permitem reconhecer as experiências dos sujeitos do universo literário como sendo semelhantes, em maior ou menor grau, aos de uma experiência individual suscetível de ocorrência no mundo em que vivemos. Desse modo, asseguram-se ao texto literário as condições para que ele atue como representação verossímil (ou realista) de situações, instaurando-se como forma de conhecimento do mundo, pois "a narrativa se sustenta [...] no desejo de que a legibilidade se dê via reconhecimento" (BRANDÃO, 2002, p. 183) - ou seja, que ocorra como identificação de uma situação crível ou factível.

As considerações acima estabelecem, portanto, que a condição de leitura das situações ficcionais seria afiançada por meio de um tipo, ainda que difuso, de descrição dos traços essenciais destes elementos. Assim, tendo por base a ideia de corpo como referência primária, as três categorias

[...] também remetem a certas características comumente associadas à noção de corpo, como mobilidade ou mutabilidade, para a categoria tempo; circunscrição ou contextualização, para espaço; e unidade ou identidade, para sujeito. Tais características atuam, no cerne de um texto verbal, como índices de reconhecibilidade dos fundamentos da experiência do corpo. O que equivale a dizer que definem a natureza realista (...) de toda narrativa. (BRANDÃO, 2002, p. 182) 
A partir dessa premissa, podemos dizer que ao ser considerado "nossa principal referência espacial e vivencial", 25 o corpo/sujeito/ser se apresenta como prisma perceptivo por meio do qual se fundamentam as conceituações discursivas de espaço e tempo. Entretanto, é importante destacar

[...] a impossibilidade de se conceituar, com precisão, as categorias espaço e tempo [e sujeito/ser, pois], tais categorias não são fixas ou absolutas: são relacionais, dependem de referências que podem estar em contínua transformação. (SANTOS; OLIVEIRA, 2001, p.91)

Assim, o sujeito/ser ficcional, seja personagem ou narrador, essa "voz de onde e por meio da qual (nos) vemos", torna-se legível apenas quando concebida em relação a um conjunto de indicações a partir do qual se configura a visibilidade, o espaço visto e o espaço visível, do texto ficcional. Esse quadro de coordenadas, que viabiliza a manifestação de conteúdos da realidade literária, pode ser descrito como "uma série de referências com as quais ele [o sujeito ficcional] se relaciona de algum modo. (...) [Portanto, é por meio dessas determinações que] imaginamos uma forma de situá-lo, atribuímos ao ser um certo estar [...] estamos produzindo um espaço para o ser." (SANTOS; OLIVEIRA, 2001, p.67) (os grifos são seus?) Então,

[...] o espaço da personagem [...] seria, desse modo, um quadro de posicionamentos relativos, um quadro de coordenadas que erigem a identidade do ser exatamente como identidade relacional: o ser é porque se relaciona, a personagem existe porque ocupa espaços na narrativa. Percebemos a individualidade de um ente à medida que o percebemos em contraste com aquilo que se diferencia dele, à medida que o localizamos. Só compreendemos que algo é ao descobrirmos onde, quando, como - ou seja: em relação a quê esse algo está. (SANTOS; OLIVEIRA, 2001, p.68) (grifos meus)

\footnotetext{
25 FUÃO. O sentido do espaço. Em que sentido, em que sentido? (parte 1 de 3), 2004. Disponível em: http://www.vitruvius.com.br/arquitextos/arq048/arq048_02.asp.
} 
Considerando que o espaço em que se localiza o ser na narrativa ficcional é esse cenário por onde as personagens circulam, podemos definir a noção de espaço, ainda que provisoriamente, como sendo um "conjunto de indicações - concretas ou abstratas - que constitui um sistema variável de relações". (SANTOS; OLIVEIRA, 2001, p.67) Esse conjunto pode ser situado fisicamente (espaço geográfico), temporalmente (espaço histórico), socialmente (espaço social), em relação às características existenciais da personagem (espaço psicológico), dentre outras possibilidades.

No que diz respeito ao conceito de tempo, no caso do texto literário, podemos falar, sumariamente, ao menos de duas formas básicas de lidar com a temporalidade. A primeira corresponde ao "tempo constitutivo da obra, elemento que traduz sua duração, determinado pelo tempo de leitura". (SANTOS; OLIVEIRA, 2001, p.50) (grifos meus) Este tempo seria correlato, por exemplo, ao tempo de leitura atribuído ao conto, caracterizado por vários teóricos do gênero como narrativa curta, em razão dos efeitos sugeridos por sua brevidade. A segunda maneira consiste na criação de um tempo ficcional, que ocorre no âmbito

[...] daquilo que é narrado, [...] no plano da história propriamente dita. Esse tempo é a atribuição de uma dimensão temporal aos eventos relatados, por meio de palavras ou expressões que recorrem, geralmente, ao calendário e ao relógio. (SANTOS; OLIVEIRA, 2001, p.51) (grifos meus)

Outra possibilidade de designação o tempo, no âmbito da ficção é, de acordo com Benedito Nunes, concebê-lo como um tempo imaginário. Essa modalidade de tempo que se manifesta na fiç̧ão é constituída por uma articulação que se dá em dois planos: "o do discurso - por meio do qual a narrativa se configura como um todo significativo - e o da história, que impõe aos acontecimentos [...] uma inteligibilidade cronológica (sucessão) 
e lógica (relação de causa e efeito)". (NUNES, 1992, p. 350) Esses dois planos podemos denominar de tempo do narrado e tempo do narrar, sendo o primeiro correlato ao tempo da estória, dos eventos da narrativa, e o segundo ao tempo histórico a que a narração se vincula, ou seja, ao conjunto de referências políticas, econômicas, sociais e culturais de determinados tempo e espaço.

Após essa breve delimitação das noções de sujeito, espaço e tempo ficcionais, convém perguntar: que relação a literatura estabelece com os sujeitos, os espaços e os tempos "reais" no contexto em que é produzida? Que imagens (ou grafias) desses conceitos emergem do texto ficcional? Compreendidos como princípios que configuraram as imagens de mundo e os valores de nosso imaginário social, os sujeitos, os espaços e os tempos manifestos no texto literário se apresentam como materializações culturalmente motivadas do conjunto de sentidos (orientações de valor, qualidades) atuantes no contexto histórico em que se efetuam. Desse modo, consideramos que tais imagens são registros que repetem a(s) realidade(s) simulada(s) pelo fingimento literário, apresentando-se, portanto, como grafias do imaginário social.

Após expor como a realidade ficcional é estruturada a partir das noções de sujeito, espaço e tempo, passemos à caracterização do gênero fantástico. A partir disso, buscaremos compreender de que modo as categorias acima são manipuladas e transgredidas, afetando o estatuto formal-realista, desvio que confere aos contos de Murilo Rubião o aspecto de fantásticos. 


\section{A literatura fantástica: o uso da ambiguidade e o efeito de estranhamento}

A princípio, pode-se dizer que a literatura fantástica é uma narrativa tão antiga quanto o próprio homem. Lendas, mitos, contos de fadas, contos, novelas ou romances ocorridos "há muito tempo atrás" ou em "uma galáxia muito, muito distante" são formas de narrar que recorrem ao que se chama de fantasia. Assim, independente da época em que foram escritas ou para quem foram feitas, se adultos ou crianças, é pela fantasia que se tem acesso aos vários mundos que existem no mundo de cada pessoa.

Em uma breve contextualização etimológica, ${ }^{26}$ o termo moderno fantástico, tomado como faculdade imaginativa, é derivado do grego phantastikós, algo ilusório que se apresenta ou se mostra para a mente, do qual decorre o termo phantásein, que significa "tornar ou fazer visível". Por sua vez, o termo fantasia, advindo da phantasía grega, expressa a possibilidade de tornar uma ideia ou noção visível, de formar imagens mentais por meio de sua representação, estando relacionado à palavra grega phantasma, "aparição", "visão", derivada do verbo pháinein, "aparecer", "mostrar", "tornar visível", "iluminar".

No entanto, a literatura fantástica se define por um modo específico de narrar, dotado de raízes históricas rastreáveis. Podemos determinar o surgimento desta modalidade ficcional e de suas primeiras realizações entre o final do século XVIII e o início do século XIX, época de grandes transformações sociais e culturais na Europa. Na introdução à antologia Contos fantásticos do século XIX (2004), o escritor e ensaísta Italo Calvino, ao expor tal mapeamento, propõe que o tema da literatura

\footnotetext{
${ }^{26}$ Para uma contextualização crítica da etimologia do termo, bem como para uma caracterização das tendências de abordagem e análise textual do fantástico na literatura, sugerimos a leitura do texto "A literatura fantástica: um protocolo de leitura" (BATALHA, 2005) e A medalha e seu reverso: o fantástico em Machado de Assis (OLIVEIRA, 2012).
} 
fantástica consiste em apresentar o problema da percepção da realidade que se dá a ver, seja "o mundo que habitamos e conhecemos por meio da percepção, [seja] a realidade do mundo do pensamento que mora em nós e nos comanda". (CALVINO, 2004, p. 9)

Ainda conforme o ficcionista italiano, a literatura fantástica é marcada por uma reflexão acerca das condições de visibilidade, ou seja, uma discussão sobre as possibilidades de apreensão e representação da realidade na literatura. Para ele, este fator abarca a relação entre imagem/discurso e realidade, ou, em outros temos, o problema da referencialidade das representações que elaboramos por intemédio da ficção.

Além dessa proposta interpretativa, Calvino apresenta, ainda, outro elemento que pode nos auxiliar a compreender a peculiaridade da literatura fantástica: o fato de este ser um "gênero crítico, de vocação filosófica". Para o autor, o fantástico adquire esta feição, por um lado, devido a suas relações com o conto filosófico francês, que se mostra como expressão da razão iluminista e, por outro, com o conto fantástico alemão, uma das manifestações estéticas do idealismo e iluminismo alemães. Desse modo, o conto fantástico é fruto da tensão entre o predomínio da objetividade / racionalidade e da imaginação / intuição, tendo por intenção "representar a realidade do mundo interior e subjetivo da mente, $[\ldots]$ conferindo a ela uma dignidade equivalente ou maior do que a do mundo da objetividade e dos sentidos". (CALVINO, 2004, p. 11)

Assim, tendo por base os comentários acima, podemos considerar que a narrativa fantástica é uma forma artística marcada pela tensão entre objetividade e subjetividade na percepção da realidade. Desse modo, elabora-se um gênero narrativo reflexivo, em que análise e imaginação se unem em uma linguagem visando a estimular outras perspectivas para observamos e questionarmos a realidade, seja dentro ou fora dos textos. Logo, da tensão dos pares opositivos (objetivo e subjetivo, razão e 
superstição, real e sonho, natural e sobrenatural), constrói-se o realismo fantástico, que toma a forma de um discurso narrativo marcado pela ambiguidade, hesitação e incerteza.

Dito isso, o que chamamos aqui de realismo fantástico é uma estética literária que coloca o problema dos limites entre o possível e o impossível, o real e o irreal (ou sobrenatural). Nessas narrativas, acontecimentos inexplicáveis e/ou impossíveis, do ponto de vista lógico ou científico, ocorrem no mundo ficcional, mas sem que sejam questionados pelo narrador ou pelos personagens. Com isso, busca-se fazer o leitor se deparar com cenas absurdas em situações cotidianas, visando a provocar as sensações de dúvida e de estranhamento, fazendo com que repense a realidade do mundo "real", à sua volta.

A partir das considerações acima, propomos o uso de um trecho do conto "O pirotécnico Zacarias" para observarmos a função da ambiguidade na construção do estranhamento e da incerteza nos contos de Murilo Rubião: "Por muito se prolongou em mim o desequilíbrio entre o mundo exterior e os meus olhos". (RUBIÃO, 1998, p. 31) Com esta frase o narrador-protagonista expõe o descompasso entre os planos do mundo e do olhar, entre o que se vê e aquele que vê. Mas não só. Ele também apresenta para nós, leitores, que é a partir deste desacordo, que atravessa o olhar dele e o nosso, que se constrói a ambivalência que caracteriza a realidade ficcional rubiana como fantástica. Como outro personagem rubiano, o delegado de "Teleco, o coelhinho", é como se as personagens nos perguntassem: "O senhor viu o que eu vi?" Sim, por um breve instante, o tempo da leitura, o fantástico nos faz ver e hesitar entre aceitar e questionar as situações apresentadas. Mas só por um momento, pois optamos por seguir o fio narrativo, na expectativa de saber o que de fato acontece nesse universo em que pessoas se transformam em verbos e camelos usam chapéu. 
Desse modo, é pelo olhar de sujeitos ficcionais que, nos contos de Murilo Rubião, somos introduzidos a um campo de referências visuais, que apresenta espaços e tempos narrativos. Assim, é a partir da visão e da voz de narradores e personagens que se instaura a incerteza em relação aos fatos e situações narrados, desestabilizando a apreensão dos sentidos do texto. Desta maneira, a ambiguidade passa de efeito de linguagem à função de elemento estruturador da realidade ficcional dos contos de Murilo Rubião. Vejamos como isso ocorre.

\section{Exemplos de um "realismo inusual"}

Conforme expusemos, na literatura de Murilo Rubião somos apresentados às arbitrariedades que presenciam (e a que se sujeitam) personagens e narradores deste universo ficcional. Por meio das situações encenadas, os contos provocam em nós a experiência de presenciarmos cenas estranhas e, não raro, perturbadoras.

De acordo com a hipótese de leitura exposta, a sensação de desorientação ocasionada pela (ir)realidade própria aos contos rubianos parece ocorrer pela maneira como o escritor manipula os elementos configuradores da percepção da realidade narrativa: sujeito, espaço e tempo. No caso do espaço, é possível pensar em, ao menos, duas possibilidades que ocasionam a desestabilização: a representação de centros urbanos imaginários, destituídos de indicações geográficas referentes à realidade não-literária, como Mangora, ${ }^{27}$ Juparassu, ${ }^{28}$ a cidade sem nome, ${ }^{29}$ Pirópolis e a Capital; ${ }^{30}$ ou a localização das narrativas em cenários situados na realidade extratextual, ora precisamente, como

\footnotetext{
27 A diáspora. In: RUBIÃO, 1998, p. 265.

${ }^{28}$ A noiva da casa azul. In: RUBIÃO, 1998, p. 51.

${ }^{29}$ A cidade. In: RUBIÃO, 1998, p. 57-63.

30 Epidólia. In: RUBIÃO, 1998, p. 173.
} 
Manacá ${ }^{31}$ e Nova Lima ${ }^{32}$, ora de modo vago, como Estrada do Acaba Mundo ${ }^{33}$ ou um vilarejo de Minas. ${ }^{34}$

No que diz respeito ao tempo, há contos em que o tratamento deste elemento chama a atenção, seja por sua configuração imprecisa ou, ainda, em razão da oscilação de temporalidades. Vejamos alguns exemplos dessa instabilidade: as digressões temporais, que acarretam transformações na paisagem e prédios da cidade e faz personagens se tornarem mais jovens no conto "Mariazinha"; as cidades que se deslocam no tempo, extinguindo ou criando lugares na medida em que o protagonista transita por elas em "Epidólia"; ${ }^{5}$ o descompasso entre a percepção temporal do protagonista e o tempo dos fatos da narrativa em "A noiva da casa azul".

Ainda sobre o elemento temporal, fato importante é o cruzamento de temporalidades decorrente da presença de epígrafes bíblicas em quase todos os contos. Isso implica na mútua contextualização do tempo mítico pelo histórico na construção do tempo das narrativas, que pode ser lido, por exemplo, como um choque entre uma concepção arcaica e outra moderna do tempo.

Quanto aos sujeitos ficcionais, estes apresentam contornos fugidios, sendo alguns destituídos de nome e, outros, dotados de capacidades metamórficas. A isso, somem-se as observações, confusas, imprecisas ou vagas, apresentadas por estes, tanto dos espaços como do tempo que ocorre à sua volta, percepções que, aparentemente, motivam a desorientação ou o desencontro entre personagens.

A partir dessas coordenadas, propomos que a ambiguidade instaura o desequilíbrio entre a realidade ficcional rubiana e a percepção desta por narradores, personagens e leitores. Esse desacordo entre o mundo e a

\footnotetext{
31 Mariazinha. In: RUBIÃO, 1998, p. 42.

32 Marina, a intangível. In: RUBIÃO, 1998, p. 79.

$33 \mathrm{O}$ pirotécnico Zacarias. In: RUBIÃO, 1998, p. 27.

34 Ofélia, meu cachimbo e o mar. In: RUBIÃO, 1998, p. 114.

35 "Pirópolis recuara no tempo e no espaço (...)". In: RUBIÃO, 1998, p. 178.
} 
leitura, a partir do qual se dá o efeito fantástico, se estrutura devido ao cruzamento e tensão entre regimes temporais conflitantes, como as sínteses rural-urbano, e os valores arcaico-moderno, configuradores da realidade brasileira.

Um exemplo do descompasso entre o olhar e a percepção da realidade temporal se encontra em "A noiva da casa azul". No início do conto, o narrador, que faz uma viagem de trem à sua cidade natal, que não visitava há poucos meses, informa ao leitor que "Juparassu surgia agora ante os meus olhos, no alto da serra. Mais quinze minutos e estaria na plataforma da estação, aguardando condução para casa". (RUBIÃO, 1998, p. 52-53) Entretanto, após o desembarque, é informado, por um agente da estação, que "nada há de interesse para ver nos arredores", (RUBIÃO, 1998, p. 54) pois a cidade se encontrava em ruínas. Diante do esclarecimento, após hesitar um instante, o narrador segue sua caminhada rumo à familiar casa de seus pais. Entretanto, o descompasso entre o visto e o visível se instaura, desestabilizando a percepção de espaço e tempo, sugerindo a disparidade entre a percepção dos fatos e sua realidade efetiva:

Não caminhara mais de vinte minutos, quando estaquei aturdido: da minha casa restavam somente as paredes arruinadas [...]. Apesar das coisas me aparecerem com extrema nitidez, espelhando uma realidade impossível de ser negada, resistia à sua aceitação. (RUBIÃO, 1998, p. 54-55)

Tal constatação é reforçada pelo desacordo entre a temporalidade vivida pelo narrador-personagem e os acontecimentos relatados por um colono. Vejamos alguns trechos que auxiliam a perceber evidências do distúrbio temporal em face do qual o narrador se vê:

No verão passado, por ocasião da morte de meu pai, os moradores da Casa Azul [...] foram levar-me suas condolências. [...] Trocamos visitas e, uma noite, beijei Dalila. 
- Então, o que veio fazer aqui? [perguntou o agente da estação ferroviária]

[...] - Tenciono passar as férias em minha casa de campo.

- Não sei como poderá.

- É coisa tão fantástica passar o verão em Juparassu? [...]

- [...] acontece que as casas de campo estão em ruínas.

[...] Procurei tranqüilizar o meu interlocutor, pois pressentia estar sob suspeita de loucura. Menti-Ihe, dizendo que há muitos anos não vinha àquelas paragens.

Rodeei a propriedade e encontrei, nos fundos, um colono cuidando de uma pequena roça. Aproximei-me dele e indaguei se residia ali há muito tempo.

- Desde menino - respondeu, levantando a cabeça.

- Certamente conheceu esta casa antes dela se desintegrar. O que houve? Foi um tremor de terra?

- Nada disso aconteceu. Sei da história toda, contada por meu pai.

A seguir, relatou que a decadência da região se iniciara com uma epidemia de febre amarela, a se repetir por alguns anos, razão pela qual ninguém mais se interessou pelo lugar (...). Acrescentou ainda que o rapaz daquela casa [o protagonista da narrativa] fora levado para Minas com saúde precária e ignorava se resistira à doença.

- E Dalila? - perguntei ansioso.

[...] - A noiva do moço desta casa?

[...] - Morreu. (RUBIÃO, 1998, p. 53-55) (grifos meus)

Ante a incredulidade do narrador, que estivera há poucos meses no local, são expostos fatos ocorridos durante anos que ocasionaram o processo de decadência e ruína do vilarejo. Após percorrer o local e caminhar por entre os destroços da cidade, permanece agoniado e desorientado em relação ao que de fato ocorreu no local após sua saída. Por onde teria andado durante a ocorrência desses fatos, que fogem a seu conhecimento? Estaria delirando? Nada é esclarecido, restando ao leitor a dúvida, por um lado, a propósito a sanidade do narrador e, por outro, a 
incerteza quanto ao que ocorreu entre a partida deste e seu retorno à sua cidade natal.

Outro conto em que se pode observar a dupla orientação, que aponta simultaneamente para um passado que insiste em permanecer no presente, é "A casa do girassol vermelho". Esta narrativa, ambientada em uma grande propriedade rural, "longe da cidade e do mundo", nos apresenta a um grupo de seis jovens que comemoram a morte do padrasto, um fazendeiro de nome Simeão, apresentado como um "fazendeiro forte e rude", "homem de moral rígida" (RUBIÃO, 1998, p. 18 e 19) e autoritário, representante dos costumes tradicionais e da ordem patriarcal. Após a morte de Simeão, tem início a liberalização dos costumes sexuais entre os filhos adotivos em oposição às proibições impostas pelo velho, que não admitia "imoralidades" em seu lar. Aqueles, mesmo face à liberdade irrestrita, se veem face à incapacidade de se livrarem da sombra do passado.

Uma alegria física inundava as faces que até a véspera permaneciam ressentidas. $O$ que veio antes e depois ficará para mais tarde.

[...] Ninguém se irritava naquele dia. Com naturalidade, virou-se para mim, que beijava a um canto a suave Marialice, e propôs:

- Vamos trocar, Surubi, você fica comigo e o besta do seu irmão se ajunta com a hipócrita da minha irmã.

[...] naquela manhã quente, queimada por um sol violento, a Casa do Girassol Vermelho, com os seus imensos jardins, longe da cidade e do mundo, respirava uma alegria desvairada. (RUBIÃ̃o, 1998, p. 15-16)

- Cambada de imorais! Se o velho Simeão estivesse vivo sairia tiro! Belinha assutou-se e, transtornada pelo terror, murmurou entre os dentes as palavras do irmão: "Se o velho estivesse vivo..."

[...] - Velho Simeão, o monstro. Está enterrado, irremediavelmente perdido na boca asquerosa dos vermes.

[...] Todos nós fôramos tocados por uma centelha diabólica, que nos fazia buscar, ansiosos, no prazer, o esquecimento dos dias de desespero do passado. (RUBIÃO, 1998, p. 17)

Em "A casa do girassol vermelho" é possível observar um mundo prémoderno em processo de desaparecimento, a se "dobrar sobre suas ruínas". (RUBIÃO, 1998, p. 23) Mesmo com a morte do representante da antiga 
ordem, esta insiste em insinuar sua permanência no presente narrativo, fato que se dá mediante a evocação constante da sombra de Simeão. Outra temporalidade que se insinua na narrativa é a da modernização, representada pelo trem e pelos automóveis que passam próximos (mas distantes) à Casa do Girassol Vermelho:

Um trem apitou ao longe e, ao passar por nós, deixou uma esteira de fagulhas. Dos carros, que seguiam velozes, saltavam quadradinhos prateados. Cheios de gente. Além de nós, havia no mundo mais alguém. (RUBIÃO, 1998, p. 21)

No conto "Epidólia", após o súbito desaparecimento da personagemtítulo, ocorrido durante um encontro com o narrador-protagonista, Manfredo, ainda "incapaz de explicar o que acontecera", se lança pela cidade em uma tentativa de localizar sua namorada. Para tanto, ele percorre vários lugares de três localidades vizinhas, Natércia, Pirópolis e a Capital, onde se deu o encontro e o desaparecimento de Epidólia. Entretanto, estes trajetos parecem ocorrer em planos temporais distintos, sugerindo que o protagonista está localizado em uma versão futura de sua cidade, como indica a passagem "[...] resolveu tomar imediatamente um táxi. $O$ automóvel que estacionou a um sinal seu diferia muito dos outros que até a véspera vira circular na Capital". (RUBIÃO, 1998, p. 170) (grifos meus) Vejamos a seguir alguns trechos que explicitam essa divergência entre os tempos divergentes do universo narrativo e a percepção destes pelo narrador-personagem:

Epidólia Ihe dissera estar hospedada no Hotel Independência, numa cidade vizinha, a cinquenta minutos do lugar onde se encontrava. [...] Manfredo já se impacientava por não terem [ainda] cruzado a zona rural, quando uma freada brusca jogou-o de encontro ao párabrisa. Na sua frente estava o hotel. (RUBIÃO, 1998, p. 170)

- Orla marítima? A cidade nunca teve mar! [...] [O hoteleiro] recuou, pedindo-Ihe calma. Esclareceria toda a situação. [...] 
- Antes eram três localidades distintas: Natércia, Pirópolis e a Capital. Tendo se expandido, encheram os vazios, juntando-se umas às outras. Com Pirópolis veio o mar. Manfredo [...] decidiu retornar à sua residência. [...] No trajeto, confirmou parte do que ouvira. $A$ ausência de vegetação, notada por ele na vinda, testemunhava a união das cidades. (RUBIÃO, 1998, p. 173)

Com o advento de Epidólia a casa se transformara. Desde a varanda e suas grades de ferro, os ladrilhos de desenhos ingênuos e seus crótons, desses que pensava não existirem mais.

Pelas salas circulavam pessoas do interior, hóspedes habituais do avô, antigo fazendeiro. Entre eles e o mofo, a velha tia passeava a cara enrugada [...] (RUBIÃO, 1998, p. 173) (grifos meus)

- Tia, as minhas coisas?! Grita por tia Sadade, que veio correndo:

- Oh! Manfredinho, estão no ginásio, onde poderiam estar?

Sorri: largara o colégio interno havia tanto tempo! (RUBIÃO, 1998, p. 174) (grifos meus)

Nos trechos acima, inexplicavelmente (ao menos para o protagonista), distâncias entre zona rural e urbana desaparecem devido à expansão urbana, que "enche os vazios e junta umas às outras", ao mesmo tempo em que o passado e o presente do narrador se confundem na fala de uma tia com quem reside. Em meio a este tempo fora dos eixos, Manfredo percorre vários locais das três cidades, antes separadas, mas agora amalgamadas, como um hotel, bares da orla marítima, a "farmácia que devia ser do século passado" (RUBIÃO, 1998, p. 176) em busca de pistas do paradeiro de Epidólia. Diante da ausência de informações sobre o paradeiro da parceira, Manfredo resolve percorrer a região das docas a gritar o nome de Epidólia. Neste instante, tão súbito quanto ocorrera o desaparecimento de sua amada e a (con)fusão temporal que uniu lugares distantes no espaço, o deslocamento do tempo se manifesta outra vez no tecido da narrativa, reforçando a sensação da divergência de temporalidades que inviabiliza o encontro entre as personagens: "Pirópolis recuara no tempo e no espaço, não mais havia mar. O parque readquiria as 
dimensões antigas, Manfredo pisava uma cidade envelhecida". (RUBIÃO, 1998, p. 178)

A partir dos exemplos acima, consideramos ser possível perceber um aspecto importante: a dupla orientação temporal que aponta, simultaneamente, ao passado e à permanência deste no presente das narrativas. Este confronto entre duas concepções temporais distintas, que coabitam em tensão permanente um mesmo espaço narrativo, tem seu sentido último na forma de estruturação da nossa formação como país situado na periferia do capitalismo. O fantástico, aqui, não surge por conta do avanço de uma racionalidade científica ou filosófica, como ocorreu na França e Alemanha. Aqui, a situação ocorreu de outra maneira: nem a racionalidade moderna se configurou plenamente, nem os elementos arcaicos perderam sua funcionalidade na organização da sociedade. Dessa aporia lógica, deriva o choque entre valores forjados em uma realidade na qual mentalidades e processos sociais do passado insistem em permanecer ativos na atualidade. Desse modo, a realidade social brasileira se constitui a partir dessas sínteses contraditórias, desses conflitos entre temporalidades de sentidos opostos, sendo a partir e em meio a esse tensionamento que ocorrem as narrativas rubianas.

Assim, tendo em vista os aspectos apontados, consideramos que Murilo Rubião, em seus contos, expressa o conflito entre estas duas racionalidades: um mundo arcaico, pré-moderno, em processo de desaparecimento, mas que insiste em afirmar a sua permanência no presente; e o mundo moderno em expansão que, todavia, não encontra forças suficientes para se firmar. Dois planos inconciliáveis, mas que não podem eliminar um ao outro, conflito que instaura um tempo fora dos eixos e que confere o tom absurdo aos acontecimentos que têm lugar nas narrativas rubianas. 


\section{Considerações finais}

Para finalizar, recorremos a uma parábola de Murilo Rubião. A nosso ver, nela se encontram algumas questões e caminhos sugeridos em nossa leitura de sua obra:

Levou a vida toda decifrando um documento. Palavra por palavra. Cinquenta anos em cima do documento. Um dia, alguém Ihe diz: - Sabes que levaste a vida toda em cima deste papel, que estás velho e morrerás dentro em pouco. O ancião olha o rosto no espelho, acaricia os cabelos brancos. Pega no documento, sacode-o, e volta a decifrá-lo. (RUBIÃO, 1992, p. 56)

Nesta narrativa, intitulada "O documento", apresenta-se a situação de um ancião que dedica sua vida à leitura de um documento. Três aspectos desta breve narrativa chamam atenção. Primeiro, o texto ilegível, que o personagem não consegue compreender ou "fazer falar", pesadelo materializado de todo leitor. Segundo, uma pessoa não identificada, que dedica sua vida a decifrar algo que escapa à sua compreensão. Terceiro, o tipo de leitura que este leitor empreende, designada como decifração, termo amplo, pois remete à escrita, à interpretação e à solução de um (suposto) enigma. Dessas, outras questões emergem: não é dito se o ancião sabe ler, assim como a finalidade que o faz se dedicar com afinco à sua tarefa; não é mencionado o teor do material ou em que língua o documento é escrito, nem mesmo se é um texto ou se se trata de uma imagem; tampouco sabemos detalhes acerca de suas características, se antigo ou novo, se literário, jornalístico, histórico, sagrado ou científico.

A partir dessa parábola, que apresenta a dificuldade ou impossibilidade de ler, coloca-se uma questão aparentemente simples, mas 
que perpassa a crítica, a história e a teoria da literatura: como ler? ${ }^{36}$ Nessa pergunta temos sintetizado o problema enfrentado seja pelo "leitor comum", seja pelo "leitor especializado", representado por pesquisadores em seus trabalhos de interpretação textual. Assim, sugerimos que, tal como a obra de Rubião, a abordagem mais instigante deste documento e dos contos consiste em um deslocamento das maneiras de percebê-los. Para tanto, consideramos necessário observar os campos referenciais e as coordenadas de sujeito, espaço e tempo que configuram não só a estrutura compositiva dos contos, mas também afetam e determinam a legibilidade da ficção rubiana. Assim, a partir de um olhar atento ao arranjo desses elementos, é possível vislumbrar os significados subjacentes para perceber os elementos da realidade extratextual que fundamentam o processo de mimese, ou a recriação do mundo no discurso literário.

De acordo com nossa proposta, o fantástico rubiano seria, portanto, definido por uma ambiguidade estrutural que se manifesta no descompasso entre os planos do mundo, do olhar e nos aspectos temporais das narrativas. Estas características têm uma função referencial, que confere veracidade à realidade descrita no texto, atuando, portanto, na organização dos elementos da narrativa, garantindo o efeito de estranhamento característico da literatura fantástica.

Outro ponto de interesse a ser desdobrado consiste na função da ambiguidade como elemento transformador da realidade social em forma literária. A nosso ver, para caracterizar a mimese rubiana, é necessário ficarmos atentos a três elementos: o conto como forma, a ambiguidade como elemento mediador e a experiência sócio-histórica brasileira (matéria local). Conforme propõe Aline Sobreira de Oliveira, o gênero conto se apresenta como "forma privilegiada de meio de manifestação da literatura

\footnotetext{
${ }^{36}$ É esta uma questão recorrente nos estudos literários. É o caso, por exemplo, de Daniel Link, Como se lê e outras intervenções críticas (Como se lê e outras intervenções críticas. Tradução: Jorge Wolff. Chapecó: Argos, 2002) ou, mais recentemente, Terry Eagleton, em Como ler literatura (Como ler literatura. trad. Denise Bottmann. 1. ed. Porto Alegre: L\& PM, 2019).
} 
fantástica", ${ }^{37}$ uma vez que seus aspectos formais (brevidade, síntese e ambivalência) são fundamentais para a construção da verossimilhança e do estranhamento na literatura fantástica. No que concerne à ambiguidade, que tratamos por um efeito advindo da imprecisão provocada pela forma como os sujeitos das narrativas percebem os espaços e tempos ficcionais, consideramos que esta atua como um elemento mediador que modela a experiência sócio-histórica brasileira na expressão literária rubiana.

A partir desses pontos, pensamos que os elementos expostos podem auxiliar a compreender a mimese rubiana como uma forma estética em que o jogo de dimensões temporais contrárias, presente na sociedade brasileira, é empregado para expressar a percepção das contradições próprias ao processo de modernização do país. Assim, a exposição do sentimento de temporalidades conflitantes, que determina a percepção da historicidade no Brasil, seria um dos nexos do realismo inusual que conformam a incoerente coerência da ficção de Murilo Rubião.

Por fim, podemos dizer que por meio da criação de uma realidade ficcional fundada na transgressão das narrativas realistas, o escritor mineiro, ao enfocar as contradições que fazem o insólito cotidiano saltar aos olhos, cunhou um tipo de representação literária que fomenta ler a realidade brasileira por outra perspectiva. Nessas narrativas, talvez possamos ver alguns traços da fisionomia de uma sociedade indecisa, atravessada e cindida entre as tensões do arcaico/tradicional e moderno, o local e o universal, o nacional e cosmopolita, o conservador e de progressista. Talvez.

\section{REFERÊNCIAS}

ADORNO, T. W.. Teoria Estética. Lisboa: Edições 70, 1982.

ARRIGUCCI JR., D.. Minas, assombros e anedotas (Os contos fantásticos de Murilo Rubião). In: Enigma e comentário: ensaios sobre literatura e experiência. São Paulo: Companhia das Letras, 1987, p. 141-165. BATALHA, M. C. . A literatura fantástica: um protocolo de leitura. In: Revista Cadernos Neolatinos. Ano IV, No 3, setembro

de 2005.

Disponível em:

\footnotetext{
37 OLIVEIRA. A medalha e seu reverso, 2012. P.34.
} 
<http://www.letras.ufrj.br/neolatinas/media/publicacoes/cadernos/a4n3/mariacristina_batalha.pdf>. em: 20 dez. 2020.

BOSI, A. (Org.). O conto brasileiro contemporâneo. 22. ed. São Paulo: Cultrix, 2008.

BRANDÃO, L. A.. Teoria do corpo na literatura brasileira contemporânea. In: DUARTE, R.; FIGUEIREDO, V.; FREITAS, V.; KANGUSSU, I. (Orgs.). Kathársis: reflexos de um conceito estético. Belo Horizonte: C/Arte, 2002, p. $182-187$.

CALVINO, Í.. Introdução. In: CALVINO, Í. (Org.). Contos fantásticos do século XIX: o fantástico visionário e o fantástico cotidiano. São Paulo: Companhia das Letras, 2004, p. 9-18.

CAMPOS, M. C. C.. Sobre o conto brasileiro. Rio de Janeiro: Gradus, 1977.

CANDIDO, A.. Crítica e sociologia. In: CANDIDO, Antonio. Literatura e sociedade: estudos de teoria e história literária. 7 ed. São Paulo: Ed. Nacional, 1985, p. 03-16. CANDIDO, A.. O significado de Raízes do Brasil. In: HOLANDA, S. B. de. Raízes do Brasil. São Paulo: Cia. das Letras, 1995. P. XXXIX-L.

FUÃO, F. F.. O sentido do espaço. Em que sentido, em que sentido? (parte 1 de 3). In: Arquitextos, 48, 2004a, Rio Grande do Sul. Disponível em: < http://www.vitruvius.com.br/arquitextos/arq048/arq048_02.asp>. Acesso em: 10 jan. 2021.

LIMA, L. C.. O conto na modernidade brasileira. In: BIENAL NESTLE DE LITERATURA BRASILEIRA: 1.: 1982. São Paulo; SANT'ANNA, A. R.. Livro do seminário: ensaios. São Paulo: L. R. Editores, 1983, p. 173-214.

LUCAS, F.. O conto no Brasil moderno. In: BIENAL NESTLE DE LITERATURA BRASILEIRA: 1.: 1982. São Paulo; SANT'ANNA, A. R.. Livro do seminário: ensaios. São Paulo: L. R. Editores, 1983, p. 103-161.

MACIEL, M. E.. Poéticas do inclassificável. In: ALETRIA. Revista de estudos de literatura. v. 15, Caderno Temático "Poéticas do espaço", Belo Horizonte, jan./jun. 2007, p. 155-161.

NUNES, B.. Tempo. In: JOBIM, J. L.. Palavras da crítica: tendências e conceitos no estudo de literatura. Rio de Janeiro: Imago Ed., 1992, p. 343-365.

OLIVEIRA, L. A.. Imagens do tempo. In: DOCTORS, M.. Tempo dos tempos. Rio de Janeiro: J. Zahar, 2003, p. 33-68.

OLIVEIRA, A. S. de. A medalha e seu reverso: o fantástico em Machado de Assis. 2012. 163f. Dissertação (Mestrado em Teoria da Literatura) - Faculdade de Letras, Universidade Federal de Minas Gerais, Belo Horizonte, 2012.

SANTOS, L. A. B.. Um olho de vidro: a narrativa de Sérgio Sant'Anna. Belo Horizonte: UFMG/FALE, 2000.

SANTOS, L. A. B.; OLIVEIRA, S. P. de. Sujeito, tempo e espaço ficcionais: introdução à teoria da literatura. São Paulo: Martins Fontes, 2001.

SCHWARZ, R.. As ideias fora do lugar. In: SCHWARZ, R.. Ao vencedor as batatas: forma literária e processo social nos inícios do romance brasileiro. 3. ed. São Paulo: Duas Cidades, 1988, p. 13-28.

REIS, C.; ROAS, D.; FURTADO, F.; GARCÍA, F.; FRANÇA, J. (Editores). Dicionário Digital do Insólito Ficcional (e-DDIF). Rio de Janeiro: Dialogarts. Disponível em: <http://www.insolitoficcional.uerj.br/i/insolitoficcional/>. Acesso em: 22 jan. 2021.

RUBIÃO, M.. O documento (parábola). In: SANTOS, Â. O. de A.; SOUZA, E. M. de. MIRANDA, W. M. (Orgs.). Minas de Liberdade. Belo Horizonte: Assembleia Legislativa de Minas Gerais/ Secretaria de Estado da Cultura de Minas Gerais, 1992, p. 56.

RUBIÃO, M.. Contos reunidos. Posfácio de Vera Lúcia Andrade. São Paulo: Editora Ática, 1998.

WAIZBORT, L.. Observação interposta sobre o desalinho de Machado de Assis. In: WAIZBORT, L.. A passagem do três ao um: crítica literária, sociologia, filologia. São Paulo: Cosac Naify, 2007, p. 232-262.

XAVIER, E. . O conto brasileiro e sua trajetória: a modalidade urbana dos anos 20 aos anos 70 . Rio de Janeiro: Padrão, 1987. 


\section{UM ESTUDO INTERGERACIONAL SOBRE O ACESSO À INFORMAÇÃO E FAKE NEWS: IMPLICAÇÕES PARA A LEITURA DE MUNDO}

Cristiane Dall'Agnol Da Silva Benvenutti ${ }^{38}$ Elizandra Jackiw ${ }^{39}$

Resumo: $O$ texto apresenta os resultados de uma pesquisa pautada pela seguinte problemática: o acesso à informação e Fake News, mediadas pelas tecnologias digitais, influencia a leitura de mundo entre as diferentes gerações? Com o intuito de responder a esta questão, foi elaborado um questionário, composto por questões abertas e fechadas que permitiram compreender as percepções de 23 participantes, pertencentes a distintas gerações, sobre o acesso a notícias, informações e Fake News que circulam no cotidiano da sociedade pelas tecnologias digitais da informação e da comunicação. Teoricamente, o estudo se fundamenta em Castells (1999), Freire (1981; 2010), Prensky (2001), Sarmento (2005), Zomer, Santos e Costa (2018). O percurso metodológico está ancorado em um estudo de natureza qualitativa, de cunho exploratório (SAMPIERI, COLLADO E LUCIO, 2015). Após a análise dos dados coletados, conclui-se que sob uma perspectiva intergeracional, a leitura de mundo é influenciada pelo acesso às notícias veiculadas pelas mídias digitais, uma vez que os sujeitos pertencentes a diferentes gerações interagem, interpretam e lidam com as informações recebidas de maneiras distintas. A compreensão sobre o acesso à informação e Fake News tem sido 
construída pelos participantes da pesquisa a partir de buscas e tentativas constantes de confirmar se as informações recebidas pelas mídias digitais são de fato verdadeiras ou não, e ainda, se há algo "oculto" nas entrelinhas das notícias que eles recebem. De maneira muito tímida, há uma sobreposição de uma geração em relação à outra e a necessidade da aquisição e domínio da leitura crítica dos meios em decorrência do surgimento da multiplicidade de mídias digitais e a intensa circulação de informações.

Palavras-chave: Leitura de Mundo. Intergeracionalidade. Tecnologias Digitais da Informação e Comunicação.

\section{Introdução}

A sociedade atual é fortemente marcada pelo acesso e uso das Tecnologias Digitais da Informação e Comunicação (TDIC) conectadas à Internet. As novas gerações, denominadas de nativos digitais (PRENSKY, 2001) ou Geração Z (ZOMER, SANTOS E COSTA, 2018), desconhecem o mundo sem a virtualidade, sem as possibilidades de acesso rápido às informações, às agilidades dos e-commerces, dos contatos pelas redes sociais e todas as facilidades que a World Wide Web (www) nos proporciona diariamente, em diferentes aspectos de nossas vidas.

Por outro lado, as gerações anteriores, denominadas por Prensky (2001) como imigrantes digitais, se viram cercados a partir das últimas décadas por estas tecnologias, mas cresceram em "um mundo analógico", pautado pela presencialidade e por recursos físicos.

De acordo com dados do Instituto Brasileiro de Geografia e Estatística (IBGE) do ano de 2017, a proporção da população idosa (60 anos ou mais) que tem acesso a Internet e aparelho celular para uso 
pessoal subiu de $24,7 \%$ no ano de 2016 , para $31,1 \%$, no ano de 2017 , e mostrou-se o maior aumento proporcional $(25,9 \%)$ entre os grupos etários analisados pela pesquisa. O maior percentual foi o grupo etário de 20 a 24 anos $(88,4 \%)$. Esses dados demonstram que o acesso às tecnologias e à Internet, e consequentemente ao mundo digital, vem aumentando significativamente ano após ano e abrange diferentes idades. O fato é que o advento das novas Tecnologias Digitais de Informação e Comunicação vem proporcionando novas formas de ver e ler o mundo.

Nesse contexto, a convivência entre as diferentes gerações pode promover a aquisição e o desenvolvimento das competências digitais, tão necessárias para a participação plena e ativa de todos os cidadãos na sociedade que ora se apresenta.

Contudo, sem sobrepor uma geração à outra, acreditamos que as relações sociais estabelecidas entre as diferentes gerações permitem a ampliação dos modos de leituar de mundo. Porém para o contrapor gerações, apresentamos um estudo de natureza qualitativa, do tipo exploratório, que tem por objetivo conhecer as percepções sobre o acesso à informação e Fake News, mediada pelas tecnologias digitais, em uma perspectiva intergeracional. Para tanto, inicia-se discutindo o conceito dos termos geração e intergeracionalidade. Em seguida, relacionam-se as TDIC à leitura de mundo, pautada na perspectiva freireana. Após estabelecer as bases teóricas, apresentamse os dados coletados a partir de um questionário composto por questões abertas e fechadas, com sujeitos na faixa etária entre 22 a 75 anos. 


\section{As diferentes gerações e a intergeracionalidade}

Para dar início às discussões acerca da intergeracionalidade convém compreender conceitualmente o que significa "geração" e resgatar historicamente as características sociais das diferentes gerações que antecederam o momento atual. O precursor do conceito foi o sociólogo Karl Mannheim (1928). Para o autor, o termo vai além da classificação etária e refere-se às experiências sociais e culturais comuns para determinado grupo durante seu crescimento e formação, os quais, portanto, partilham das mesmas experiências históricas. Este conceito, cuja natureza é essencialmente cultural, desconsiderava, à época, aspectos biológicos, filosóficos e estruturais que o envolvem.

Nesse sentido, aproximamo-nos da definição elaborada por Sarmento, ao integrar fatores de diferentes naturezas em sua definição. Para ele, a geração trata-se

[...] de um constructo sociológico que procura dar conta das interações dinâmicas entre a geração-grupo de idade, isto é, as relações estruturais e simbólicas dos actores sociais de uma classe etária definida e a geração-grupo de um tempo histórico definido, isto é, o modo como são continuamente reinvestidas de estatutos e papéis sociais diferenciadas os actores de uma determinada classe etária, em cada período histórico concreto. (SARMENTO,2005, p.367)

Compreende-se, assim, que as gerações são caracterizadas por pessoas nascidas em uma mesma época e que compartilharam experiências comuns na formação da subjetividade. Mais explicitamente, o conceito extrapola a classificação etária ao considerar que as experiências comuns vividas por sujeitos que nasceram em determinado período histórico e, portanto, que experienciaram as mesmas relações estruturais simbólicas, encontram em suas 
subjetividades os mesmos princípios e fundamentos, mesmo levandose em conta a individualidade. Por exemplo: pessoas nascidas na década de 70 compreendem a moda, os comportamentos, as relações, de maneira distinta daqueles que viveram outras décadas, mesmo tendo experiências de vida individuais.

Zomer, Santos e Costa (2018) se baseiam em autores como Kotler e Keller (2006), McCrindle e Wolfinger (2009), Ceretta e Froemming (2011), para afirmar que na atualidade quatro gerações convivem simultaneamente: os Baby Boomers (nascidos entre os anos de 1945 e 1960), a geração X (nascidos entre os anos de 1960 e 1970), a geração Y (nascidos entre os anos de 1980 e 1990) e a geração Z (nascidos após a década de 90). Estes autores enfatizam, todavia, que esta classificação não é unânime na literatura, embora se constate certa homogeneidade em relação aos períodos de corte.

Para caracterizar cada uma das gerações, Zomer, Santos e Costa (2018) levam em consideração os aspectos sociais e políticos de cada período. A geração Baby Boomers é formada pelo grupo de indivíduos que vivenciaram o fim da Segunda Guerra Mundial. Atualmente compreendem a faixa etária entre 60 a 75 anos. Estes se caracterizam por experienciarem a escassez dos bens de consumo, o crescimento demográfico das cidades com o retorno dos soldados e a industrialização. "São pessoas idealistas, que crescem como jovens indulgentes após uma crise, cultivam princípios moralistas na meia idade e emergem como visionários na velhice" (ZOMER; SANTOS E COSTA, 2018, p.202).

Nesse período, os meios de comunicação predominantes na sociedade brasileira eram a mídia impressa e o rádio. A televisão, inaugurada no Brasil em 1950 pelo jornalista e empresário Assis Chateubriand, ainda caminhava a passos lentos e apenas duas décadas depois é que chegava massivamente aos lares do país. 
A geração $X$, por sua vez, é caracterizada pela vivência em um período de transição e instabilidade financeira das décadas de 60 e 70. Essa geração vivenciou a Ditadura Militar brasileira e seus efeitos econômicos e sociais. De acordo com Zomer, Santos e Costa (2018), seus membros aprenderam a entrar no mercado de trabalho desde cedo e a valorizar suas carreiras. Em contrapartida, se viram bombardeados por propagandas e comerciais televisivos, incentivando o consumismo e o ideário de uma nação soberana. Além disso, no ano de 1972, o primeiro computador brasileiro foi colocado em funcionamento na Universidade de São Paulo (USP).

A geração $Y$ é formada por pessoas nascidas entre as décadas de 80 e 90 . Este grupo geracional é fortemente marcado pela luta a favor de democracia e liberdade. É marca desse grupo o movimento das "Diretas Já!", a maior campanha popular da época, em favor das eleições diretas. Para Zomer, Santos e Costa esta geração é caracterizada por sujeitos "confiantes, relaxados, conservadores e a geração mais educada de todas" (2018, p.204). Em relação ao acesso à informação, presenciou rápidas mudanças nos meios de comunicação e a evolução tecnológica nos diferentes setores da sociedade: filmadoras e gravadores portáteis, toca-fitas, vídeo games, walkman e outra infinidade de eletroeletrônicos invadiram os lares. Os computadores domésticos começaramm a se tornar populares e em 1988 a Internet chega ao Brasil.

Por fim, a geração $Z$ corresponde aos nascidos na década de 90 em diante. Conhecidos também como "screenagers" (do inglês, geração familiarizada e habilidosa no uso de dispositivos eletrônicos), estas pessoas viram o aparelho celular chegar ao Brasil, no início dos anos 90 , e se transformar nos smartphones mais modernos e atuais. Zomer, Santos e Costa afirmam que estas pessoas são multitarefas, com "elevados níveis de criatividade, expressividade e individualidade, 
conectados a dispositivos mobile entre outros recursos tecnológicos" (2018, p. 207). Desconhecem o mundo sem a Internet, são consumidores ávidos de informações e possuem intensa relação com os recursos tecnológicos.

Cada geração, portanto, caracteriza-se por experienciar realidades diferentes, que estão relacionadas aos aspectos políticos, sociais, culturais e de acesso e avanço das tecnologias. Não se pode esquecer, contudo, que as diferentes gerações coexistem e as relações entre elas, a intergeracionalidade, são estabelecidas inicialmente pela família.

De acordo com Borges e Magalhães, no seio da família "estão reunidas pessoas que vêm de tempos diferentes, que nasceram e cresceram em momentos distintos e, por isso, pessoas que percebem e sentem os acontecimentos do presente de maneiras diferentes" (2011, p. 173). É nesse sentido que procuramos, neste estudo, conhecer, adotando uma perspectiva intergeracional, as percepções sobre o acesso à informação e Fake News, em uma sociedade midiatizada e tecnológica como a nossa.

Em um contexto social que apesenta uma acelerada disseminação de informações nas redes sociais tecnológicas, mas sem que ocorra uma reflexão e contestação sobre a veracidade dos fatos. Assim, a relação intergeracional na contemporaneidade pode propiciar maior proximidade entre as pessoas de diferentes gerações, conforme (BORGES; MAGALHÃES, 2011, p. 171-174) defendem que

[...] na medida em que suas diferenças ficam diluídas em meio ao grande volume de inovações socioculturais produzidas continuamente.[...] a intergeracionalidade, em contextos de transformações constantes, pode apresentar fluxos recíprocos de socialização que podem ser mais ou menos tensos à medida que diferentes gerações tenham perspectivas, expectativas e representações mais ou menos distintas sobre a sociedade. 
Seja como for, as relações intergeracionais fazem parte de nosso cotidiano, seja na família, no espaço de trabalho, no círculo de amizades, entre outros. Cabe a cada grupo, por sua vez, compreender que a leitura da realidade está relacionada à construção dos sistemas simbólicos e subjetividades de cada sujeito, historicamente situado, como veremos a seguir.

\section{A leitura de mundo e as tecnologias digitais da informação e comunicação (TDIC)}

Na sociedade atual, afirma Castells, estamos "diante de um novo paradigma tecnológico que se organiza em torno da tecnologia da informação" (CASTELLS,1999, p.67). Isso significa que as TDIC passaram a assumir um papel relevante na comunicação $e$ disseminação das informações. Para o autor, as tecnologias da informação não são apenas ferramentas a serem utilizadas, mas processos a serem desenvolvidos, ou seja, usuários e criadores podem conferir, como no caso das ferramentas colaborativas (wikis) e redes sociais (Facebook, Twitter, YouTube, Instagram). Para ele, este sistema tem sua própria lógica embutida,

[...] caracterizada pela capacidade de transformar todas as informações em um sistema comum de informação, processando-as em velocidade e capacidade cada vez maiores e com custo cada vez mais reduzido em uma rede de recuperação e distribuição potencialmente ubíqua (CASTELLS, 1999, p. 51).

Isso significa que as ferramentas tecnológicas integram diferentes mídias que permitem construir uma nova estrutura para os textos: som e imagem estão inseridos dentro de espaços virtuais 
disponíveis em computadores, os quais possibilitam formas variadas de comunicação, interatividade e acesso às informações, por meio de celulares, tablets, smartphones, smart TV. Sobre isso, Almeida destaca que

[...] a navegação em sistema hipermidiático permite, a quem o utilize, percorrer distintos caminhos, criar múltiplas conexões entre informações, textos e imagens; ligar contextos, mídias e recursos. Cada sujeito que explora um sistema hipermídia torna-se receptor e emissor de informações, leitor, escritor e comunicador. Assim, a TIC envolve o sujeito em um mar de informações e, ao mesmo tempo, incita-o à leitura e à expressão através da escrita textual e hipertextual. (2001, p. 6)

O mundo dos textos midiáticos permite ao usuário encontrar-se conectado constantemente e acessar as informações em tempo real, pois sua circulação é imediata, dinâmica e livre. Todo esse acesso instantâneo e imediato a uma infinidade de informações modifica a maneira como os sujeitos compreendem e lidam com os acontecimentos e com a interpretação da realidade. Almeida (2001, p. 2), destaca que o uso de tecnologias digitais possibilita a comunicação e a troca de experiências a partir da produção de histórias do cotidiano real, que altera o desenvolvimento pessoal, profissional e dos grupos de pessoas, bem como a compreensão da realidade.

De acordo com Paulo Freire (1985), a compreensão da realidade se relaciona ao conceito de leitura de mundo. Para ele, a leitura de mundo está relacionada com os sistemas simbólicos, às múltiplas linguagens, e é um "comportamento que envolve ação e reflexão[...]", a pessoa tem o direito de "expressar-se e expressar o mundo, de criar e recriar, de decidir, de optar" (1985, p.59). E, portanto, uma leitura de mundo em rede surge como quase que na velocidade da luz. Esta 
leitura requer um olhar mais atento para o profundo sentido e significado das mensagens veiculadas do que somente para a quantidade de informações.

O autor explica que, nas sociedades massificadas, os sujeitos pensam e agem de acordo com as prescrições que recebem diariamente dos meios de comunicação. "Nestas sociedades, em que tudo ou quase tudo é pré-fabricado e o comportamento é quase automatizado, os indivíduos 'se perdem' porque não têm de 'arriscarse'". Os indivíduos, afirma Freire, "Não têm de pensar em torno das coisas mais insignificantes; há sempre um manual que diz o que deve ser feito na situação 'A' ou na situação 'B'"' (FREIRE, 1981, p. 68).

Nesse sentido, a tecnologia deixa de ser percebida como uma das grandes expressões da criatividade humana, e passa a ser tomada como uma espécie de nova divindade a que se cultua. Nas palavras de Freire:

\begin{abstract}
A eficiência deixa de ser identificada com a capacidade que têm os seres humanos de pensar, de imaginar, de arriscar-se na atividade criadora para reduzir-se ao mero cumprimento, preciso e pontual, das ordens que vêm de cima. Ou seja, a racionalidade, fundamental à ciência e à tecnologia, cede seu lugar ao "irracionalismo" mitificante, sob os efeitos extraordinários da própria tecnologia (FREIRE, 1981, p.68).
\end{abstract}

Todavia, o autor explica que seria simplismo atribuir a responsabilidade por esses desvios à tecnologia em si mesma. Vista criticamente, ela "não é senão a expressão natural do processo criador em que os seres humanos se engajam no momento em que forjam o seu primeiro instrumento com que melhor transformam o mundo" (FREIRE,1981, p.68). Considerando que a tecnologia não é apenas necessária, mas foi incorporada ao cotidiano do ser humano e do 
desenvolvimento de suas atividades, o problema maior é o de como evitar os desvios e interpretações diversas sobre as informações que são propagadas.

Para Freire, nenhuma informação é apenas o que aparece na forma linguística que a expressa: "Há sempre algo mais oculto, mais profundo, cuja explicitação se faz indispensável à sua compreensão geral" (1981, p.78). Dessa forma, conhecer significa

[...] buscar tanto quanto possível, romper as aparências enganosas que podem conduzir-nos a uma distorcida visão dele. Isto significa que temos de realizar o esforço difícil de desembaraçá-lo destas aparências para apanhá-lo como fenômeno dando-se numa realidade concreta (FREIRE, 1981, p.78).

Então, escrever sobre um tema, como o entendemos, não é um mero ato narrativo. Ao apreendê-lo, como fenômeno dando-se na realidade concreta, que mediatiza os homens, quem escreve tem de assumir frente a ele uma atitude gnosiológica. Os que leem, por sua vez, assumindo a mesma atitude, têm de re-fazer o esforço gnosiológico anteriormente feito por quem escreveu. Isto significa que quem lê não deve ser um simples paciente do ato gnosiológico daquele que escreve.

Diante do exposto, o que nós, receptores e leitores de informações, temos a fazer não é propriamente definir o conceito relacionado ao tema de uma informação, por exemplo; tampouco, tomados pelo que ele, o assunto, envolvoe, descrevê-lo ou explica-lo simplesmente. Do contrário, deve-se assumir diante do tema/informação uma atitude comprometida com a verdade dos fatos. Tal atitude é a de que quem não pretende apenas descrever o que se passa, como se passa. É preciso, sobretudo, lidar com informações e 
fatos de maneira crítica, questionando-se a forma dos acontecimentos e as certezas sobre eles, pois acontecimentos mudam constantemente, e o que é certeza em um momento, pode se dar de forma diferente em outro. (FREIRE, 1981

\section{Acesso à informação e Fake News: um estudo intergeracional}

A pesquisa realizada se insere em uma abordagem qualitativa, de cunho exploratório. Sampieri, Collado e Lucio (2015) afirmam que a essência da pesquisa qualitativa é compreender e aprofundar os fenômenos, que são explorados a partir da perspectiva dos participantes em um ambiente natural e em relação ao contexto.

Sob esta perspectiva, foi elaborado um questionário composto por doze perguntas. Destas, quatro questões eram fechadas e versavam sobre a frequência de acesso às informações por meio das TDIC e o seu nível de confiabilidade.

Para estas questões, utilizou-se uma escala tipo Likert, com cinco possibilidades de respostas: "Sim, diariamente", "Sim, quinzenalmente", "Sim, mensalmente", "Raramente", "Não costumo utilizar". Também se utilizou uma escala, de 0 a 5 para enumerar 0 grau de confiabilidade dos participantes em relação às informações acessadas pelas TDIC, em que 0 significa nada confiável e 5 significa totalmente confiável. As outras oito questões que compunham o questionário eram do tipo aberta e versavam sobre os modos de lidar e interpretar as informações veiculadas pelas mídias digitais, incluindo as chamadas Fake News.

Importante destacar que, dentre as questões do tipo aberta, duas eram especificamente destinadas para pessoas a partir de 60 
anos de idade, e duas eram destinadas aos participantes com menos de 60 anos.

Tal instrumento de coleta de dados foi enviado no mês de janeiro de 2021, de maneira on-line, a quarenta voluntários residentes na cidade de Curitiba. A escolha dos participantes se deu por conveniência das pesquisadoras. Importante destacar que os participantes assinaram o Termo de Consentimento Livre e Esclarecido antes de iniciar suas participações na pesquisa. Tal formulário contemplou o objetivo do estudo, os procedimentos e os benefícios da pesquisa e seguiu os critérios éticos necessários à uma pesquisa científica.

Responderam ao questionário vinte e três participantes. Os dados e as narrativas coletadas foram interpretadas à luz dos estudos de Bruner (1991), que destaca o uso das "falas" dos participantes para expressar suas vidas, permitindo ao pesquisador uma análise mais profunda.

Para garantir o anonimato dos participantes, eles foram identificados por letras seguidas de numeração (exemplo: P01, para participante 01; P02, para participante 02, e assim sucessivamente).

A análise dos dados permite-nos afirmar que o perfil dos participantes se caracteriza como heterogêneo, em que 8 se declararam do sexo Masculino e 15 do sexo Feminino, cuja faixa-etária se situa entre 22 a 75 anos. No gráfico(Gráfico 1) abaixo, apresentase a frequência das faixas-etárias dos participantes. 
GRÁFICO 1 - FREQUÊNCIA ETÁRIA DOS PARTICIPANTES

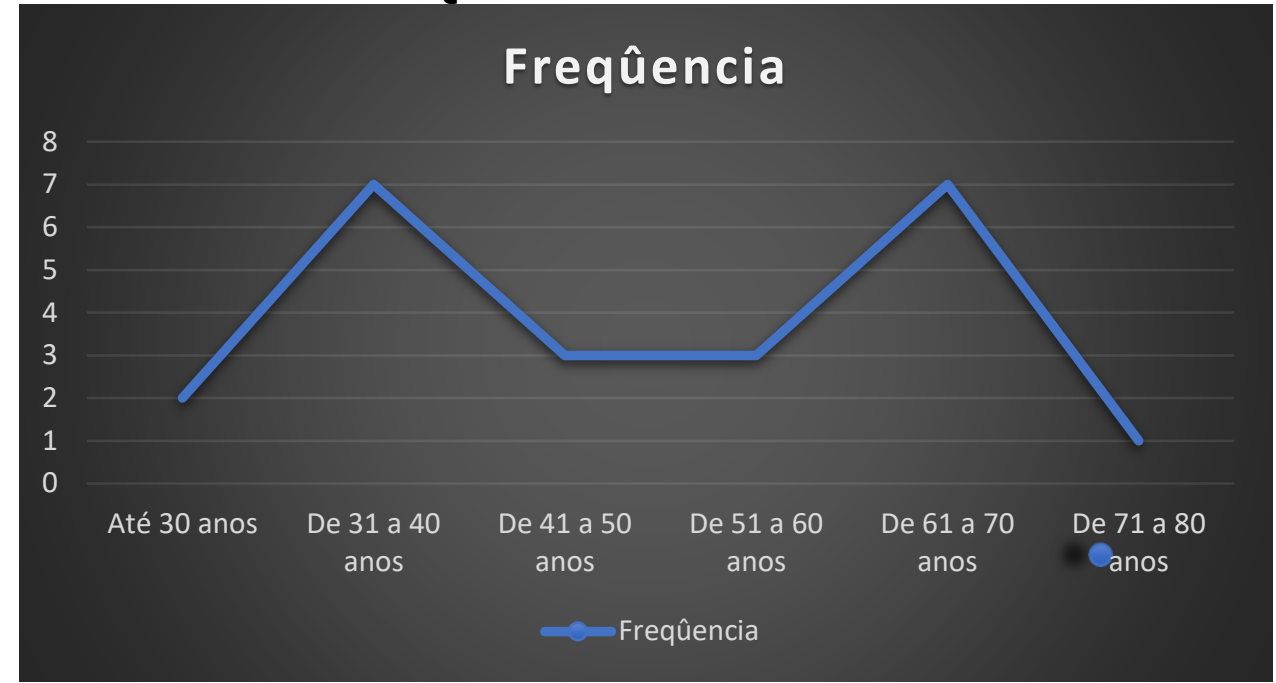

FONTE: BENVENUTTI; JACKIW (2021)

Analisando-se o perfil etário sob a categorização das gerações utilizadas por Zomer, Santos e Costa (2018), obtém-se que: 8 participantes fazem parte da geração Baby Boomers, 6 participantes correspondem à geração $X, 7$ fazem parte da geração $Y$, e 2 respondentes fazem parte da geração $Z$, conforme verifica-se no Gráfico 2:

GRÁFICO 2 - PARTICIPANTES E SUAS GERAÇÕES

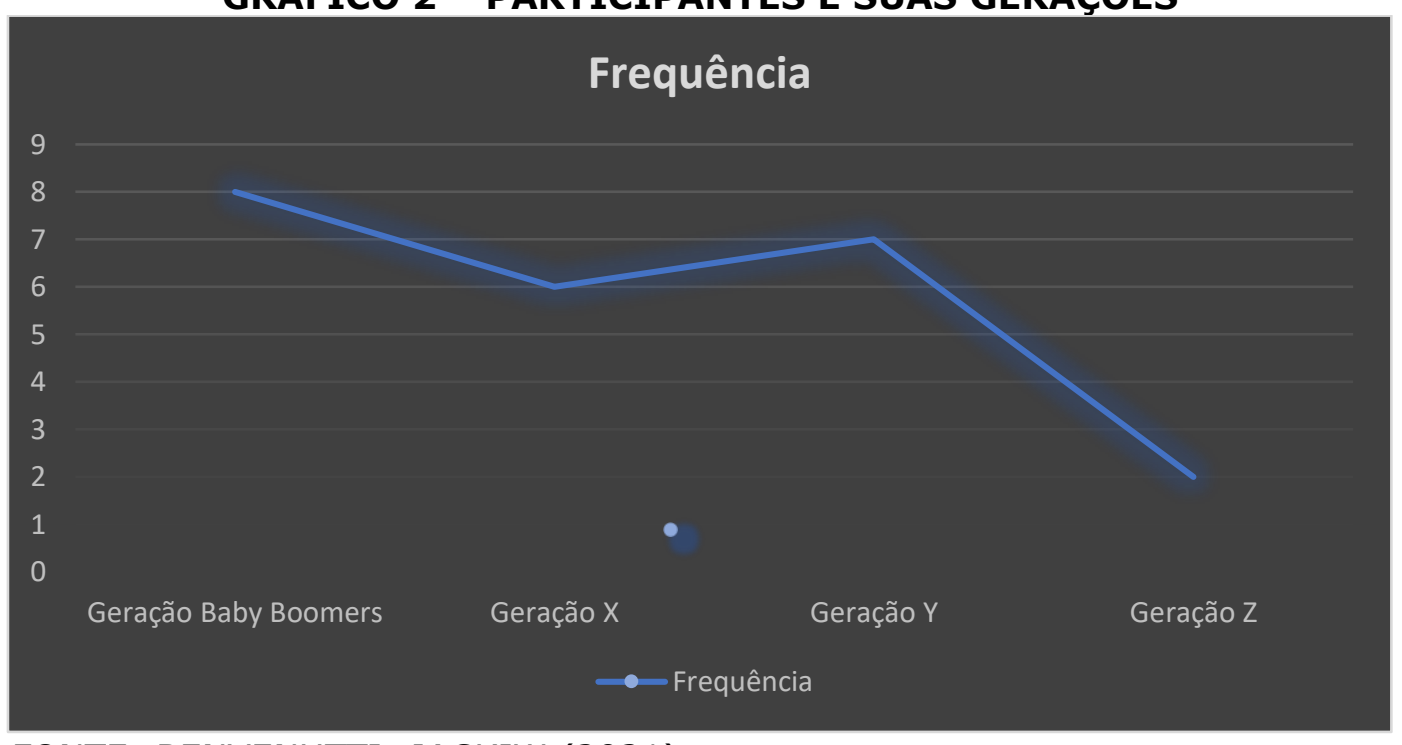

FONTE: BENVENUTTI; JACKIW (2021) 
Quando questionados sobre a frequência de utilização das TDIC para acesso às informações, tem-se que 16 participantes as utilizam diariamente, 3 as utilizam semanalmente e 4 raramente utilizam as tecnologias digitais para acessar informações e/ou notícias.

Com relação ao nível de confiabilidade das informações veiculadas pelas mídias digitais, os respondentes utilizaram uma escala numérica de 0 a 5 , em que 0 significava nada confiável e 5 significa totalmente confiável. A análise dos dados indicou que 10 participantes classificaram a confiança como " 2 ", 8 participantes classificaram a confiabilidade como "3", 3 respondentes classificaram as informações com o nível "4" e 2 participantes indicaram que o nível de confiabilidade é " 1 ". Nenhum respondente assinalou as respostas 0 e 5 . Isso significa que, para os participantes, as informações veiculadas não são totalmente confiáveis, mas por outro lado, pode-se confiar nelas, em alguma escala.

Quando questionados sobre o significado do termo Fake News, todos os participantes afirmaram conhecê-lo e o definem como "Falsa notícia/informação" (P01), "Coisas que não se pode acreditar" (P10) ou "Notícias falsas, inventadas ou manipuladas por alguém" (P12).

Questionados se já haviam se deparado com alguma notícia falsa veiculada pelas mídias digitais, todos disseram que sim, especialmente sobre temas como a pandemia da Covid-19, morte de famosos e política. Dentre os participantes, um relatou que recebeu notícias falsas durante a campanha para a prefeitura de uma cidade do Paraná, em que a oposição veiculou, por meio de uma rede social, que a compra e distribuição de Kit do Programa Nacional de Alimentação Escolar (PNAE), teria sido utilizado para a compra de votos (P15). Já duas participantes destacaram que no início da pandemia da Covid-19 receberam publicações duvidosas: "recebi a ligação do Ministro da Saúde Mandeta, falando sobre a pandemia, algumas de políticos e 
outras sobre a eficácia da vacina" (P14). Outro participante afirma: "recebi ligações e mensagens no meu WattsApp sobre a forma como a doença age no meu corpo, e recentemente sobre as vacinas, que são duvidosas e podem causas doenças incuráveis" (P23).

A questão seguinte se referia a como eles percebiam a presença de notícias falsas nas mídias digitais. Obtivemos respostas semelhantes de todos os participantes, que basicamente afirmam que as Fake News se apresentam como "exagero ou deturpação da realidade" (P04), quando "utilizam de recursos midiáticos para chamar a atenção do leitor" (P06). Em outras situações, "as notícias são tendenciosas, porque elas tentam levar para outras opiniões, por vezes sobre políticas..." (P17), "Muitas são as notícias falsas veiculadas nas mídias digitais, principalmente sobre a vacina da Covid-19" (P19).

Questionados sobre o que faziam para checar se a informação veiculada era verdadeira ou falsa, caso se deparassem com alguma notícia duvidosa, os respondentes apresentaram dois tipos de comportamento que se resumem a: "Geralmente apenas ignoro a informação veiculada" (P02) e "Deixo pra lá, não dou bola" (P09), indicando passividade diante do que é veiculado e, por outro lado, diferente postura, mais reflexiva: "Quando tenho dúvidas pesquiso em sites de jornalismo confiável" (P08) e "Procuro fontes oficiais e dados científicos sobre o assunto" ( $p 12)$.

Dos relatos dos participantes, este chama a atenção, pois envolve a organização das informações dentro do espaço da família:

Nós temos um lema aqui na minha família que é assim: quando tem alguma notícia circulando muito, ninguém dispara para nenhum outro grupo ou pessoas. $E$, como temos um dos meus filhos que é muito bom na área digital, ele sempre confirma pra (sic) gente se é ou não falsa. Por exemplo, se vem pelo Instagram, antes de reportarmos para outros, 0 que recebemos, ele sempre confere se é real por meio dos sites do 
governo, das secretarias como da Saúde, Ministério Público, Ministério da Educação (P18).

No que tange à intergeracionalidade, a pergunta era sobre se a relação com as diferentes gerações poderia, de alguma maneira, facilitar o acesso a informações veiculadas pelas TDIC. Como resultado, obteve-se que todos os participantes acreditam que as relações estabelecidas entre as diferentes gerações auxiliam, de alguma maneira, o acesso às informações.

Os participantes da geração Baby Boomers e da Geração X acreditam que a convivência com as gerações mais novas (filhos/as, netos/as, sobrinhos/as, entre outros) é benéfica porque "me ajudam a acessar e a navegar pela Internet" (P03), "indicam sites e conteúdos confiáveis" (P02), "Falam o que é verdade ou mentira" (P07). Outro participante destacou que:

\begin{abstract}
A geração de hoje em dia, que a gente fala, ela é na área digital, muito mais rápida do que a gente, Né? Eu tenho um filho caçula, tudo o que eu peço para ele, ele já vê, confirma. $E$, a gente nem imagina que poderia acessar aquele site para verificar uma informação. $E$, assim como nós temos que aprender com a geração dos mais novos, eles também precisam aprender com a gente, que é mais velho. Eu vejo pelos meus netos e netas, eles acessam os joguinhos, e os menores, as criancinhas, entram escolhem as músicas, sozinhos. É uma coisa fantástica (P18).
\end{abstract}

Os participantes da geração $Y$ e da geração $Z$ afirmam que a convivência com as gerações mais velhas é benéfica porque, "como temos que ensiná-los a mexer com as tecnologias e a acessar redes sociais, isso acaba nos fazendo aprender mais" (P05). Além disso, "por vezes eles são mais curiosos e buscam vários temas diferentes [de pesquisa]. Quando compartilham conosco, ficamos sabendo de várias curiosidades" (P04). O participante (P20) relatou que "a experiência 
dos mais velhos não pode ser desconsiderada, mas nós mais jovens percebemos mais rápido, por exemplo, quando uma notícia ou informação é Fake News."

Os participantes (P22) e (P21) acreditam que "é preciso muito (sic) paciência, pois muitas situações são complicadas e ocorrem quando queremos explicar sobre uma informação que é falsa. A pessoa idosa acaba discutindo, e até fala que a nossa geração desconhece sobre a história mundial ou do país. Vejo isto muito com o meu pai" (P22). Já o participante P21, este afirma que:

Às vezes, a pessoa idosa confunde muito as informações. Acredita muito nas mensagens que recebe no celular ou que assistiu nos jornais da televisão. Ela pega a informação como única e verdadeira sem compreender o que existe de real diante daquela situação. É complicado ajudá-la a compreender, pois acredita que a uma inversão de valores. É difícil! (P21).

Outra questão, relacionada à intergeracionalidade, referia-se à distinção sobre informações e Fake News veiculadas pelas mídias digitais. A análise dos dados demonstra que os respondentes acreditam que a relação intergeracional influencia (positivamente ou negativamente) a distinção entre as notícias falsas e as informações confiáveis.

A geração Baby Boomers e a Geração X afirmam que a convivência com as gerações mais novas auxilia na distinção, pois "eles [mais jovens] costumam ter mais conhecimento sobre o mundo virtual" (P02) e quando solicitados "trocam informações e indicam fontes oficiais" (P01). Por outro lado, confessam que "em algumas vezes eles não tem (sic) paciência para explicar, pesquisar e só dizem que não é verdade" (P13) e, "em algumas situações, quando 
compartilho ou comento alguma informação que vi, eles questionam, mas às vezes não concordo com eles" (P07).

Os respondentes da geração $Y$ e da geração $Z$ afirmam que a convivência com as gerações mais velhas pode trazer outras perspectivas, devido "a experiências e conhecimento histórico que têm" (P02). Mas, também, porque "podemos auxiliá-los, pois não estão acostumados com a linguagem persuasiva que as mídias digitais atuais podem utilizar para propagar falsas notícias" (P11).

Por outro lado, um participante afirma que "quando as pessoas ficam mais idosas acreditam mais facilmente em notícias falsas, e as compartilha. Quem mora com elas fica mais suscetível à Fake News" (P08).

Os participantes (P20) e (P19) destacaram que,

[...] como as gerações mais velhas tem (sic) mais tempo livre, elas acessam e recebem mais informações pela televisão, rádio e mídias sociais, pelo menos com as pessoas que eu convivo. Inclusive as pessoas idosas me repassam de 3 a 5 informações por dia sobre acontecimentos atuais, e eu preciso verificar se são verdadeiros ou falsos. Dá trabalho! (P20)

As pessoas mais velhas tem (sic) a tendência de acreditar em mais Fake News do que a geração mais nova, a nossa geração, talvez por não ter crescido com os meios digitais e a velocidade das informações. (P22)

Nesses contextos narrados pelos participantes, observamos que as transformações da sociedade se colocam evidentes a partir do advento da Internet e das tecnologias digitais. O perfil dos leitores, das gerações de leitores, exige o descortinar do letramento digital e midiático, pois os interlocutores estão constantemente expostos às diversas e diferentes informações que são construídas sobre um tema ou assunto, e se apresentam carregados de sentidos e significados. 
Porém, estes temas ou assuntos, expostos nas mídias digitais, necessitam ser compreendidos em sua totalidade original por todas as gerações.

De acordo com Araújo,

[...] existe uma espécie de "cultura planetária", que é audiovisual pela qual as pessoas se inserem e com ela convivem. Dentro dessa "cultura planetária, as imagens são consideradas fatores de propagação e representação da informação em larga escala, e as gerações acompanharam ao longo de inúmeros acontecimentos da história mundial (2007, p.5).

Por isso, para a produção de sentidos e significados em textos digitais considera-se fundamental a compreensão de uma informação recebida, por parte do leitor, além de conhecimento prévio sobre as diversas fontes midiáticas.

\section{Considerações finais}

O intuito deste artigo era o de compreender se o acesso à informação e às Fake News, mediadas pelas tecnologias digitais, influencia a leitura de mundo entre as diferentes gerações. Após a análise dos dados coletados, a pesquisa evidenciou que, sob uma perspectiva intergeracional, a leitura de mundo é influenciada pelo acesso às notícias veiculadas pelas mídias digitais, uma vez que os sujeitos pertencentes à diferentes gerações interagem, interpretam e lidam com as informações recebidas de maneiras distintas. Enquanto as Gerações Baby Boomers e $X$ tendem a acreditar que aquilo que é 
veiculado pela mídia é factível, reafirmando a máxima que diz que "se está na mídia é verdade", as Gerações Y e Z, por se perceberem consumidores e produtores de conteúdos para as mídias digitais, conseguem navegar mais facilmente pelos canais de distribuição e verificação da veracidade das notícias.

A maneira como as gerações detectam a veracidade das informações evidenciou que representantes da Geração Baby Boomers e Geração X recorrem às pessoas da Gerações Y e $Z$ para desmistificar se uma informação é ou não Fake News. Porém, todas as Gerações descrevem caminhos semelhantes para averiguar se uma informação é falsa, como sites oficiais de órgãos federais, estaduais e/ou municipais.

As narrativas nos levaram a observar que a velocidade com que as informações circulam na sociedade e são decodificadas, compreendidas e/ou interpretadas, acentuam a necessidade de se olhar para a questão da educação para as mídias, no sentido de leitura crítica dos meios. Paulo Freire relata, em uma passagem interessante, sua relação com as informações veiculadas pelas mídias:

Sou um telespectador tão exigente de mim mesmo que me cansa assistir programas de televisão, porque não me entrego docilmente [...]. Dificilmente um comercial me apanha desprevenido [...]. Eu analiso os comerciais de modo geral e descubro neles, imediatamente, os cortes de classe, por exemplo, os cortes de sexo, o corte de raça, entendes? (FREIRE, 2013, p. 35).

A leitura crítica dos meios e a leitura de mundo estão diretamente relacionadas atualmente, uma vez que nos encontramos em uma sociedade midiatizada e tecnológica. O problema é se perguntar a serviço "do quê" e a serviço "de quem" os meios de comunicação e as 
mensagens veiculadas se acham. E essa é uma questão que tem a ver com as maneiras do sujeito compreender e conhecer a realidade.

\begin{abstract}
Conhecer, na dimensão humana, que aqui nos interessa, qualquer que seja o nível em que se dê, não é o ato através do qual um sujeito, transformado em objeto, recebe, dócil e passivamente, os conteúdos que outro lhe dá ou impõe. O conhecimento, pelo contrário, exige uma presença curiosa do sujeito em face do mundo. Requer sua ação transformadora sobre a realidade. Demanda uma busca constante. Implica em invenção e em reinvenção. Reclama a reflexão crítica de cada um sobre $o$ ato mesmo de conhecer, pelo qual se reconhece conhecendo e, ao reconhecer-se assim, percebe o "como" de seu conhecer e os condicionamentos a que está submetido seu ato. Conhecer é tarefa de sujeitos, não de objetos. E é como sujeito e somente enquanto sujeito, que o homem pode realmente conhecer. (FREIRE, 1983, p. 16)
\end{abstract}

A pesquisa também demonstrou que há uma atmosfera de boas práticas resultante do círculo de convivência entre as pessoas próximas dos participantes e que geram colaboração, uma espécie de "solidariedade intergeracional" que são identificadas nas narrativas pelas palavras 'orientações', 'ajuda', 'troca de informações' e 'explicação'. Essa forma de "solidariedade" pode atenuar a exclusão de pessoas da Geração Baby Boomers e Geração X, em virtude dos avanços tecnológicos que crescentemente podem impor restrições, e as pessoas dessas gerações buscam suporte para compreender as tecnologias, mídias digitais e as informações que provem delas.

Por outro lado, os pertencentes às gerações mais novas utilizam a experiência de vida e a curiosidade dos representantes das gerações mais velhas para ter acesso a temas e assuntos que dificilmente buscariam por conta própria e, neste sentido, as diferenças ficam diluídas em meio ao volume de informações compartilhadas.

Por isto, concluímos que a compreensão das percepções sobre o acesso à informação e Fake News, mediada pelas tecnologias digitais, em uma perspectiva intergeracional perpassam diferentes tempos, espaços e culturas que foram constituindo a subjetividade dos 
participantes da pesquisa. O espaço da família é um dos locais que notícias e informações são discutidas e dialogadas com uma maior intensidade.

\author{
O esvaziamento de uma busca por tentar compreender a \\ informação e a notícia com base em pesquisas conceituadas é uma \\ constante que cresce no campo da TDIC, o que desencadeia no \\ empobrecimento da cultura, do conhecimento científico e avanço de \\ um país. Dois pontos relevantes para o desenvolvimento de pesquisas \\ futuras.
}

\title{
REFERÊNCIAS
}

ALMEIDA, M. E.. Tecnologia de informação e comunicação na escola: aprendizagem e produção da escrita. Série Tecnologia e Currículo. Programa Salto para o Futuro, Novembro, 2001.

ARAÚJO, J. C. (Org.). Internet e Ensino: novos gêneros, outros desafios. Lucerna: Rio de Janeiro, 2007. BORGES, C. C.; MAGALHÃES, A. S.. Laços intergeracionais no contexto contemporâneo. In: Revista Estudos de Psicologia, 16(2), maio-ago. 2011, p. 171-177.

BRUNER, J.. The narrative construction of reality. In: Critical Inquiry. v.18. n.1, Chicago: The University of Chicago Press. Autumn. 1991.

CASTELLS, M. A Sociedade em rede. São Paulo: Paz e Terra, 1999.

CERETTA, S. B; FROEMMING, L. M. Geração Z: Compreendendo os Hábitos de Consumo da Geração Emergente. In: Revista Eletrônica do Mestrado Profissional em Administração da Universidade Potiguar. Ano III, n. 2, abr.-set 2011, p. 15-24.

FREIRE, P.. A Ação cultural para a liberdade. 5. ed. Rio de Janeiro: Paz e Terra. 1981.

FREIRE, P.. Extensão ou comunicação? 7. ed. Rio de Janeiro: Paz e Terra, 1983.

FREIRE, P.. A importância do ato de ler: em três artigos que se completam. São Paulo: Autores Associados: Cortez, 1985.

FREIRE, P.; GUIMARÃES, S.. Educar com a mídia: novos diálogos sobre educação. Rio de Janeiro: Paz e Terra, 2013.

KOTLER, P.; KELLER, D.. Administração de Marketing. 12. ed. São Paulo: Pearson Prentice Hall, 2006. MANNHEIM, K.. (1928). A questão das gerações. In: FORACCHI, M. M. (Org.), Sociologia. São Paulo: Ática, 1982, p. 67-95.

MCCRINDLE, M. WOLFINGER, E. The ABC of XYZ: understanding the global generations. Sydney: University of New South Wales Press Ltd., 2009.

PRENSKY, M. Nativos digitais, imigrantes digitais. Trad. Roberta de Moraes Jesus de Souza. Local: Editora, 2001.

SARMENTO. M. J.. Gerações e alteridade: interrogações a partir da sociologia da infância. In: Revista Educação e Sociedade, Campinas, v. 26, n. 91, p. 361-378, maio - ago. 2005.

SAMPIERI, R. H.; COLLADO, C. F.; LUCIO, M. P.. Metodologia de pesquisa. 5. ed. Porto Alegre: Penso, 2015.

ZOMER, L. B.; SANTOS, A. R.; COSTA, K. C. O.. O perfil de alunos do curso de Administração: um estudo com base nas gerações X, Y e Z. In: Revista GUAL, Florianópolis, v.11, n.2, p.198-221, maio 2018. 


\section{ENSINO DE PRODUÇÃO TEXTUAL: RECONFIGURAÇÃO DO PAPEL DO PROFESSOR E DA ESCOLA}

Danielle Fracaro da $\mathrm{Cruz}^{40}$

Resumo: $O$ presente artigo tem como objeto trazer uma reflexão bibliográfica sobre o papel do professor frente às novas tendências educacionais, considerando as mudanças na educação a partir das reflexões sobre a sociedade do conhecimento que faz presente no século XXI. Traz como ponto de partida o papel da escola, a formação (continuada) do professor, o processo de ensino-aprendizagem evidenciando o ensino da produção textual. Destacando a relevância na forma como as novas tendências educacionais estão relacionadas à tecnologia, dessa forma demonstrando que uma modificação na forma do ensino de produção textual, sem deixar de considerar os aspectos que são extremamente relevantes ao processo de ensino: o texto e suas partes, os gêneros e as necessidades que se fazem presente por todos os cidadãos. Ao considerar as mudanças que se fazem presentes na educação, como gêneros digitais, destaca-se a importância de repensar e reconstruir os currículos a fim de embasar o trabalho do professor.

Palavras-chave: Professor. Escrita. Tecnologia.

${ }^{40}$ Currículo Lattes: http://lattes.cnpq.br/0349097133654053. 


\section{Introdução}

Escrever bem é, ainda hoje, no século XXI, um desafio pertinente e muito considerável, pois é papel da escola alfabetizar para a vida e para a prática na sociedade. O exercício pedagógico vem sendo norteado a partir de novas tendências educacionais, que apresentam abordagens com o objetivo de direcionar o formato do processo de ensino e aprendizagem de forma mista. Com o advento da internet, há, hoje, novos modos de ler e de escrever, o que faz com que haja necessidade de uma prática pedagógica diferenciada. Com isso, configuram-se novos ambientes de aprendizagem: o virtual e a sala de aula física, buscando definir um sistema de ensino híbrido. O ensino de produção textual ainda é visto como algo que está longe das telas dos computadores. Entende-se, com isso, que, na prática pedagógica, o professor de produção textual deve sempre reforçar aos seus alunos que os textos são instrumentos de mediação social, utilizados em várias atividades comunicativas que exigem conhecimento e domínio da linguagem (BAZERMAN, 2006).

As transformações sociais acontecem, rapidamente, em diversos âmbitos que permeiam a sociedade e as relações de trocas estabelecidas entre os indivíduos, gerando, assim, diversos modos e possibilidades de utilização da linguagem, como reflexos incontestáveis das mudanças tecnológicas, que se tornam progressivamente emergentes. Assim, buscam-se maneiras de conduzir o processo do ensino da escrita e envolver o aluno, desde recursos tecnológicos digitais até a formação do professor: inicial e continuada. Para João Thomaz Pereira, essa revolução faz com que os professores encarem o desafio de se preparar para essa nova realidade, aprendendo a lidar com os recursos básicos para o seu planejamento em sala de aula (PEREIRA, 2005). 
Um outro aspecto relevante é considerar todas as competências e as habilidades que devem ser trabalhadas e desenvolvidas. A prática pedagógica deve estar sempre alinhada à produção do conhecimento do aluno, uma vez que essa deverá ser construída a partir das trocas e, principalmente, visando o papel do professor como um agente mediador do conhecimento. Com isso, busca-se realinhar o currículo escolar, seguindo os direcionamentos sugeridos pelos documentos oficiais.

Dessa forma, buscou-se ao longo do estudo identificar a formação do professor de língua portuguesa para o trabalho com a produção textual em meio as tecnologias de informação e comunicação e, também, realizar o levantamento das possibilidades de práticas que podem ser realizadas pelos professores. Para isso é preciso, primeiramente, entender a relevância dos gêneros do discurso e suas implicações na sociedade, considerando as necessidades de comunicação e interação do ser humano, identificando também o uso das possíveis plataformas digitais para edição de textos.

\section{A reconfiguração do papel do professor}

O papel do professor tem um destaque no processo de ensino, já que é necessário considerar o contexto e as particularidades do aluno. José Moran destaca que, quando a escola padroniza, também ensina e avalia de forma igual, é por isso que, segundo ele, a sociedade do conhecimento deve ser regida a partir de competências, que configuram a proavitidade, colaboração e também a visão empreendedora, como afirma Morin:

A escola padronizada, que ensina e avalia a todos de forma igual e exige resultados previsíveis, ignora que a sociedade do conhecimento é baseada em competências cognitivas, pessoais e sociais, que não se adquirem da forma convencional 
e que exigem proatividade, colaboração, personalização e visão empreendedora. (MORAN, 2014, p.30)

O ensino tem, por sua vez, o objetivo de promover a assimilação dos conteúdos, mas, além disso, tem também o objetivo de desenvolver as capacidades cognitivas dos alunos, de forma a colocálos como protagonistas de seus próprios conhecimentos. Cabe ao professor mediar a interação, estimulando o desenvolvimento cognitivo por meio de atividades educativas (LIBÂNEO, 1994).

Não se pode falar em prática educacional, sem falar das habilidades do século XXI, pois, no que diz respeito ao papel do professor, é relevante refletir que a atuação profissional na ação educativa, hoje, é baseada nas habilidades necessárias que são mediadas pela ação e interação das construções instigadoras perante a atuação do indivíduo que faz parte da sociedade contemporânea, visando buscar resultados desejáveis para a educação (GOMES, 2012). Portanto, é válido considerar os domínios de percepções a serem desenvolvidos, desde a comunicação, pensamento crítico, metacognição, autorregulação, além de requisitos fundamentais, como responsabilidade, resolução de conflitos etc.

Dessa forma, cabe ao professor buscar estratégias dentro da sua experiência e percepção de mundo para gerenciar da melhor forma o processo de ensino e de aprendizagem, evidenciando também a criatividade, a memória, e os demais aspectos cognitivos que fazem parte do processo. A inteligência emocional também deve ser desenvolvida, juntamente com as habilidades relacionais, permitindo que os alunos exponham suas ideias e respondam ao estímulo de outras pessoas.

É preciso considerar que cada professor, mesmo que tenha uma base de formação que seja atribuída aos demais profissionais da educação, deverá observar o seu próprio papel, ou seja, não é conveniente que os professores passem a seguir os comandos de 
diretrizes curriculares de forma unificada. A educação só passa a ser transformadora, e atinge seus objetivos, quando se estabelecem trocas entre os agentes formadores. Assim, ao atribuir um papel para o professor, deve ficar claro que, em momento algum, é possível generalizar ao ponto de ignorar as especificidades de cada um na sala de aula:

\begin{abstract}
Não existe um papel do educador que seja geral, aplicável a qualquer educador ou educadora. Admitir que haja um papel universal, é cair numa posição ingênua. É desconhecer, por exemplo, a natureza política do ato educativo. [...] É a partir daí que o seu papel se constitui, se consubstancia, na sua prática evidente o que leva a colocação de uma série de questões. (FREIRE, 1984, p. 7).
\end{abstract}

O homem aprende e apreende as coisas do mundo, podendo se colocar a favor ou contra as diversas situações, uma vez que a linguagem faz parte das suas interações sociais, possibilitando-o construir e desenvolver a sua identidade. A cada nova experiência, os aspectos sociais se modificam e o espaço apresenta um novo sentido ou significado para o sujeito que dele faz parte.

A prática educativa se modifica conforme se modificam também as ações sociais, agregando as especificidades conforme as necessidades dos indivíduos. Dessa forma, ao refletir sobre os aspectos relacionados à prática docente, é importante refletir sobre o papel do professor em todo o processo educativo. O professor passa a não ser mais visto como um mero transmissor do conhecimento e, sim, aquele que faz com que seus alunos reflitam sobre as coisas do mundo. Assim, cabe ao docente conhecer os seus alunos e perceber seu desempenho a partir das necessidades, pois a prática pedagógica é vista como social, ou seja, não basta apenas transmitir conteúdo, é necessário permitir que o aluno pense, desenvolva a sua criticidade.

No processo de ensino da leitura e da escrita, conta-se com o apoio de diversos textos de diferentes formatos e objetivos, a fim de 
desenvolver de forma significativa a prática discursiva dos alunos. Assim, eles perceberão como funcionam e circulam os efetivamente textos na sociedade, compreendendo o objetivo maior de estar aprendendo e praticando na escola.

O papel do professor que ensina a prática da escrita não está apenas centralizado no ensino da estrutura da língua ou no formato estipulado para o texto, ou seja, para a tipologia ou mesmo o gênero textual. O trabalho deve ir muito além, uma vez que é preciso atingir os objetivos sócio-políticos, que são definidos pela organização educacional local, ou seja, orientar-se ao que está previsto em currículo escolar. Sendo assim, a prática do ensino da escrita deve estar alinhada com os objetivos que baseiam a concepção de língua adotada pelas teorias, as quais sustentam as diretrizes curriculares do sistema político-educacional. Para Bronckart:

\footnotetext{
O primeiro princípio de uma didática da produção escrita é que os objetivos sociais, tal como definidos pela política escolar de um determinado país, são absolutamente prioritários, e que a teoria deve estar a serviço desses objetivos sócio-políticos. Isso significa que não devemos simplesmente "aplicar" as teorias ao ensino (rejeição do aplicacionismo), mas, ao contrário, escolher elementos teóricos que pareçam ser úteis e adaptá-los no quadro dos programas e dos métodos de ensino (princípio da transposição didática). (BRONCKART, 2010, p.171)
}

O trabalho pedagógico da prática da escrita, além de contribuir para manter tradições, muitas vezes, contribui também para que o aluno identifique o contexto do aprendizado e consiga conectar as formas reais de uso da escrita e, principalmente, da leitura. Dessa forma, é de extrema relevância que os objetivos que permeiam o trabalho de produção textual estejam claros para o professor, pois é essencialmente importante que relacione, tome como base textos já existentes, estimulando os alunos sobre o contexto a ser desenvolvido de forma discursiva. 
As transformações sociais acontecem de forma cada vez mais acelerada, em diversos âmbitos que permeiam a sociedade e as relações de trocas estabelecidas entre os indivíduos. As modificações geram diversas maneiras e possibilidades de utilização da linguagem, como reflexos incontestáveis das mudanças tecnológicas, que se tornam a cada instante mais emergentes em nossa sociedade. Refletem, sem dúvida, no processo da prática pedagógica de forma bastante significativa. Busca-se, portanto, uma solução para os impactos que permeiam o universo educacional, desde recursos até a formação do professor.

Ao refletir sobre as diversas ações educativas, é perceptível visualizar, de maneira bem nítida, que a ação pedagógica tem se tornado cada mais transformadora no que diz respeito ao desenvolvimento do indivíduo. Ela considera todas as competências e, principalmente, as habilidades que são trabalhadas e desenvolvidas, e busca alcançar objetivos desejáveis.

O docente deve atuar de maneira a desenvolver a ação pedagógica, levando o educando a pensar criticamente e desenvolver seus conhecimentos com base nas transformações sócio-políticoculturais. Assim, ressalta-se a importância de a prática educativa estar sempre alinhada à produção do conhecimento do aluno, uma vez que este deverá ser construído a partir das trocas, visando, principalmente, o papel do professor como um agente mediador do conhecimento.

O ensino de produção textual ainda é visto como algo que está longe das telas de computadores. Para isso, o desafio da pesquisa é mostrar as possibilidades da tecnologia na transmissão dos conteúdos, possibilitando ao aluno aprender de forma significativa e colocando em prática seus conhecimentos ativamente na sala de aula, com a prática de metodologias ativas.

É necessário pensar em mudanças na forma de descrever e entender o leitor, bem como é necessário pensar no aluno não apenas 
como leitor, mas, também, como escritor. Isso se deve ao advento e à onipresença da Internet, pois hoje, há novos modos de ler e escrever, e tudo está inserido em uma cultura. Sabe-se, por isso, que é de extrema importância oportunizar ao aluno a prática de produção textual na escola, mas é preciso também reconhecer que a sociedade passa por uma mudança que é significativa, o que faz com que essa prática seja cada vez mais diferenciada, por se tratar de uma sociedade atravessada pelo digital.

As novas tendências educacionais reconfiguram o papel do professor, principalmente no que diz respeito às necessidades de modificações e perspectivas sociais presentes no século XXI. Em decorrência desses fatos, é preciso repensar o papel da escola, a formação (continuada) do professor, o processo de ensino e aprendizagem. No que diz respeito ao ensino de produção textual, evidenciam-se as novas vertentes que estão relacionadas às tecnologias digitais. Assim, demonstra-se que é significativo repensar o ensino de produção textual, considerando os novos recursos didáticos que facilitam a aproximação do aluno com uma aprendizagem significativa. Para isso, é preciso analisar os fatores que apresentam uma grande magnitude ao processo de ensino da escrita: o texto e suas partes; os gêneros do discurso, partindo do pressuposto de que surgem a partir das necessidades que se fazem presentes no cotidiano do sujeito; e, deve ser considerado, também, o próprio processo da escrita.

\section{Gêneros digitais \& ensino de produção textual}

O uso das tecnologias digitais radicalizou a prática da escrita. A sociedade torna-se cada vez mais textualizada diante de todas as possibilidades e recursos de comunicação que, por hora, muitas podem ser mediadas pelo computador. Isso implica entender que 0 
desenvolvimento se dá por meio da organização do texto e do seu contexto, seja por meio dos sites de redes sociais, como nas situações rotineiras dos indivíduos, seja em ambientes virtuais de aprendizagem, que proporcionam essa possibilidade como recurso metodológico.

Tal contexto determina conhecimento e interação maior do professor com esses textos que emergem no ciberespaço. Entende-se que, quando a comunicação é mediada pelo computador, não apenas em salas de bate-papo, mas também nas diversas possibilidades de trabalhar a produção textual em sala de aula, é de extrema importância considerar determinados aspectos que dizem respeito à apropriação linguística, como a organização estrutural e o uso dos elementos fundamentais para a estruturação da produção.

Pode-se afirmar que há uma mudança radical na produção de textos a partir das Tecnologias Digitais de Informação e Comunicação (TDICs) e que talvez nem a reconheçamos ainda. Não, as mudanças não descaracterizam a produção de texto, mas a modifica, amplia. $O$ professor, enquanto mediador, precisa estar atento aos novos gêneros, aos gêneros que circulam nos meios digitais e que são usados para comunicação, o que significa ratificar o postulado bakthiniano de que nos comunicamos a partir de diferentes gêneros (BAKHTIN, 2016). A questão é: o ensino de produção textual precisa estar atrelado à realidade do aluno, tal como apregoado pelos Parâmetros Curriculares Nacionais desde o ano de 1998.

Coscarelli e Corrêa salientam que, para falar sobre a produção de texto por meio das tecnologias digitais, é necessário que se compreenda, minimamente, que letramento digital vai muito além do que digitar em computador (COSCARELLI; CORRÊA, 2018). No contexto da cibercultura, a produção textual pode ser colaborativa, a mudança do polo de emissão (LEMOS, 2003) precisa ser considerada 
e debatida com os alunos, assim como a desterritorialização. ${ }^{41} \mathrm{~A}$ possibilidade da inserção de hipertextos na escrita deve ser instigada, o meme, por exemplo, é um gênero a ser discutido.

O ensino da língua em suas diversas vertentes deve ser entendido como uma atividade de caráter social, ou seja, a linguagem humana apresenta um funcionamento, com uma determinada função de necessidade. $O$ conhecimento das particularidades que conduzem o trabalho deve pressupor que o indivíduo utilize a língua para negociar seus significados com os demais e, assim, poderá expressar tanto seus pensamentos, quanto interagir com demais interlocutores. Para Bakhtin,

[a] verdadeira substância da língua não é construída por um sistema abstrato de formas linguísticas nem pela enunciação isolada, nem pelo ato psicofisiológico de sua produção, mas pelo fenômeno social de interação verbal, realizada através da enunciação ou das enunciações. A interação verbal constitui assim a realidade fundamental da língua. (BAKHTIN, 1995, p. 125)

Sabe-se que a língua portuguesa se apresenta contextualizada e bem diversificada quando se fala de gêneros textuais. Assim, o desenvolver do trabalho com prática de produção textual no âmbito educacional deve, sem dúvida, oportunizar ao aluno os diferentes contextos, uma vez que os aspectos interdisciplinares, quando bem trabalhos pelo professor, possibilitam expandir o conhecimento sobre o funcionamento da língua nos seus contextos de uso, ou seja, nas atividades culturais e sociais (MARCUSCHI, 2005, p.18). Com isso, entende-se que o trabalho com a gramática deve partir das situações

\footnotetext{
${ }^{41}$ Conceito proposto pelos filósofos Gilles Deleuze e Félix Guattari. Desterritorialização implica um vetor de saída em um território, oportunizando a criação de novos territórios, o que pressupõe uma reterritorialização. (DELEUZE e GUATTARI, 2001). Sendo assim, no que diz respeito ao conhecimento, o conceito se aplica na perspectiva de criações de novos olhares, novos espaços, os quais são mais acessíveis, flexíveis e descontínuos.
} 
do cotidiano do aluno e não como algo completamente fora da função do texto trabalhado. Para Marcuschi:

A circulação dos gêneros textuais na sociedade é um dos aspectos mais fascinantes, pois como a própria sociedade se organiza em todos os seus aspectos [...], os gêneros são a manifestação mais visível desse funcionamento que eles ajudam a constituir, envolvendo crucialmente a linguagem, atividades enunciativas, intenções e outros aspectos. (MARCUSCHI, 2006, p.30)

As atividades que são desenvolvidas no dia a dia estão todas relacionadas à linguagem, pois estão atreladas às relações sociais que são exercidas em diferentes contextos e esferas sociais pelos indivíduos, a partir de suas necessidades, produzindo então o discurso. Vale lembrar que os gêneros textuais não são fixos, ou seja, estão em modificação constante e apresentam características flexíveis. Segundo Bakhtin, os gêneros estão presentes em todas as ações comunicativas, assim, o texto é um instrumento que possibilita a comunicação entre os indivíduos, sendo ele de número infinito que circula em várias áreas sociais diferentes.

Entende-se, então, que, na prática pedagógica, o professor de produção textual deve sempre reforçar aos seus alunos que os textos são instrumento de mediação social, utilizados em várias atividades comunicativas que exigem conhecimento e domínio da linguagem. Para Bazerman,

[o]s gêneros nos ajudam a navegar dentro de complexos mundos da comunicação escrita e da atividade simbólica, porque, ao reconhecer uma espécie de texto, reconhecemos muitas coisas sobre a situação social e institucional, as atividades propostas, os papéis disponíveis do escritor e do leitor, os motivos, as ideias, as ideologias e o conteúdo esperado do documento e o lugar onde isso tudo pode caber em nossa vida. (BAZERMAN, 2006, p. 84). 
Na prática docente, é de suma importância que haja sempre a reflexão, pois a educação transformadora será sempre provida e promovida com tomadas de decisões e processos de avaliação, identificando a inovação nas práticas com experiências de aprendizagem e verificando se estão sendo suficientes para a construção do conhecimento dos alunos. A formação continuada do professor não pode ficar na premissa apenas do estudo e embasamento do papel do professor, mas sim a realidade do papel do professor frente às transformações sociais e principalmente intelectuais que se faz em uma educação inovadora. É certo afirmar, claro, que

[a] concepção da escola e do papel dos professores não é unânime. As diferentes posições sobre formação dos professores podem mascarar divergências mais fundamentais. Infelizmente, não podemos defender a hipótese de que todos os Estados desejam formar professores reflexivos e críticos, intelectuais e artesãos, profissionais e humanistas. (PERRENOUD, 2002, p. 15).

Ainda sobre a formação dos professores frente às transformações da sociedade, é de extrema relevância que o profissional faça, periodicamente, uma reflexão sobre a sua atuação. Para Perrenoud,

Isso se complica ainda mais pelo fato de que vários cursos de formação inicial estão baseados mais em uma visão prescritiva da profissão do que em uma análise precisa de sua realidade. Naturalmente, nada nos obriga a adaptar a formação inicial à realidade atual de uma profissão. A formação não tem nenhum motivo para abordar apenas a reprodução, pois deve antecipar as transformações. Logo, para fazer as práticas evoluírem, é importante descrever as condições e as limitações do trabalho real dos professores. Essa é a base de toda estratégia de inovação. (PERRENOUD, 2002, p.17)

Diante de tantas informações e tantas possibilidades de construção no espaço educacional, passa a ser necessário considerar todas as informações que circulam 0 universo dos alunos, 
possibilitando-Ihes a reflexão sobre elas e o papel que essas influenciam na construção do conhecimento, moldando as possibilidades de interações por meio de textos que permeiam o ciberespaço. É preciso, antes de tudo, criar possibilidades de que a construção do conhecimento se torne cada vez mais crítica, a partir do universo inovador e de produção do conhecimento textual de forma digital.

Ressalta-se que a formação do professor é de extrema relevância para poder moldar e saber atuar de forma bastante relevante diante do cenário da sociedade do conhecimento. Além disso, sabemos da importância de repensar o currículo e formas que preveem as possibilidades de trabalho diante das ferramentas digitais e da interação do aluno com o meio de informação e comunicação. Considerando-se esses aspectos de extrema relevância para o desenvolvimento e o processo de construção do conhecimento, o estudo realizado foi descritivo, bibliográfico, realizado sob metodologia de pesquisa narrativa. A pesquisa se deu no campo educacional, refletindo sobre as tecnologias educacionais, sendo incorporadas a partir da perspectiva de sociedade digital, contextualizando o aluno que faz parte desse cenário e evidenciando seu desenvolvimento como leitor e escritor.

O trabalho com prática de produção textual deve ser entendido como uma simulação e uma metáfora da conversação oral. Contudo, diante das pesquisas na área, nota-se que, dentro nos textos mediados pelo computador, há elementos e evidências cada vez maiores da similaridade, principalmente a partir da incorporação de ferramentas digitais no cotidiano dos indivíduos. Assim, a escola tem um papel de mediar e fazer reflexão com os alunos sobre suas possibilidades de escrita, seguindo as suas particularidades e regras (RECUERO, 2009). 


\section{Algumas considerações}

É de extrema relevância refletir sobre a mudança que hoje ocorre no ensino de línguas, mais especificamente com a produção textual. Mesmo com as diversas mudanças, precisa-se insistir no trabalho com textos, partindo de suas particularidades e necessidades. São várias as possibilidades e recursos para desenvolver um trabalho de letramento digital, permeando a construção do conhecimento no espaço escolar. Do uso de aplicativos para desenvolver a interação até à relação com recursos para produzir textos diversos, não se pode limitar o processo de ensino e aprendizagem apenas ao texto escrito, mas ao texto de uma forma geral, atributo dos distintos espaços discursivos de um determinado grupo ou sociedade.

A partir da pesquisa e dos estudos realizados, destaca-se a necessidade de um novo perfil do professor, que possa refletir e compreender a realidade em que está inserido. Não basta apenas acrescentar os recursos tecnológicos nas aulas, é preciso demonstrar a consciência em relação ao seu uso, principalmente destacando os novos moldes para a produção de texto. Todo o universo escolar deve estar preparado para receber esse aluno, mas a prática docente é primordial para atingir os objetivos propostos com tantos recursos. Para isso, mais uma vez, há a necessidade de investir em formação continuada para os professores.

Ainda sobre a formação docente frente às transformações da sociedade, é de suma importância que o profissional faça, periodicamente, uma reflexão sobre sua atuação. Segundo Perrenoud, há vários cursos de formação inicial que estão sempre buscando uma visão mais prescritiva do que reflexiva (PERRENOUD, 2002). Dessa forma, destaca-se a relevância em refletir, também, sobre as possíveis condições e limitações para desenvolver um trabalho de qualidade, identificando as condições e também as limitações. 
É possível ressaltar que, ao considerar o papel do professor como mediador no processo e ensino aprendizagem, é relevante pensar na forma como a ação pedagógica leva o educando ao processo de pensamento por meio da criticidade frente às diversas situações colocadas pelos demais na sociedade. $\mathrm{E}$ ainda, hoje o desafio é muito maior e mais desafiador para o professor, uma vez que precisa considerar o que é previsto nos currículos educacionais e, ao mesmo tempo, considerar que o aluno faz parte de uma sociedade que é digital.

Do exposto, depreende-se que hoje, no século XXI, a ação desafiadora da educação, do papel da escola, se dá em uma escala muito maior. Com isso, as tendências pedagógicas devem acompanhar a evolução e a transformação social, pois o formato do processo de ensino e aprendizagem precisa ser significativo e relevante para o universo do aluno. É preciso fazer e atribuir diferentes sentidos ao que é estudado: o conteúdo não basta ser apenas mais um eixo temático da grade curricular a ser cumprida.

Foi de extrema relevância refletir sobre a mudança que hoje ocorre no trabalho que se tem com a língua, mais especificamente com a produção textual. Mesmo diante dessas diversas mudanças, parece clara a necessidade de se insistir no trabalho com textos, partindo de suas particularidades e das necessidades dos interlocutores. Cabe a cada professor e a cada rede de ensino se inteirar e promover 0 diferencial ao aluno que, desde pequeno, está inserido nesse contexto, e precisa saber fazer uso devido dos recursos, bem como é preciso conhecer formas diferentes de interação com textos no universo escolar. 


\section{REFERÊNCIAS}

BAKHTIN, M.. Os gêneros do discurso. Trad. Paulo Bezerra. São Paulo: Editora 34, 2016.

BAKHTIN, M.. Marxismo e filosofia da linguagem. Trad. Michel Lahud e Yara Frateschi Vieira. 7.ed. São Paulo: Hucitec, 1995.

BAZERMAN, C.. Gêneros textuais, tipificação e interação. Trad. Judith Chambliss Hoffnagel. São Paulo: Cortez, 2006.

BRONCKART, J.-P.. Gêneros de textos, tipos de discurso e sequencias: por uma renovação do ensino de produção escrita. Letras, Santa Maria, v. 20, n. 40, p. 163-176, jan./jun. 2010. Disponível em: <https://periodicos.ufsm.br/letras/article/view/12150>. Acesso em 29 abr. 2021.

COSCARELLI, C.; CORREA, H.. Letramento digital. In: MILL, D. (Org.). Dicionário crítico de educação e tecnologias e de educação a distância. Campinas: Papirus, 2018. p. 385-387.

DELEUZE, G.; GUATTARI, F.. O que é a filosofia? Tradução Bento Prado Jr. e Alberto A. Muñoz, São Paulo, ed. 34, 200.

FREIRE, P.. 0 papel do educador. Disponível em: <http://acervo.paulofreire.org:8080/jspui/bitstream/7891/1035/3/FPF_OPF_06_015.pdf>. Acesso em: 10 abr. 2021.

GOMES, P.. Pesquisa americana releva as habilidades que precisam ser desenvolvidas nas crianças e jovens durante sua formação. Disponível em: <http://porvir.org/conheca-competencias-para-seculo21/>. Acesso em: $07 \mathrm{fev} .2018$.

LEMOS, A.. Cibercultura: alguns pontos para compreender a nossa época. In: Olhares sobre a cibercultura. Porto Alegre: Sulina, 2003.

LIBÂNEO, J. C.. Didática. 1. ed. São Paulo: Cortez, 1994.

MARCUSCHI, L. A.. Gêneros textuais: definição e funcionalidade. In: DIONÍSIO, Angela Paiva; MACHADO, Anna Rachel; BEZERRA, Maria Auxiliadora (Orgs.). Gêneros textuais e ensino. 3 ed. Rio de Janeiro: Lucerna, 2005.

MARCUSCHI, L. A.. Produção textual, análise de gêneros e compreensão. São Paulo: Parábola Editorial, 2008

MORAN, J. M.. A educação que desejamos: novos desafios e como chegar lá. 5. ed. Campinas: Papirus, 2014.

MORAN, J. M.. Educação Humanista Inovadora. Disponível em: <www2.eca.usp.br/moran>. Acesso em: 20 mar. 2018.

PEREIRA, J. T.. Educação e Sociedade da Informação. In: COSCARELLI, C. V.; RIBEIRO, A. E.. Letramento digital. Belo Horizonte: Autêntica, 2005.

PERRENOUD, P.. As competências para ensinar no século XXI: a formação dos professores e o desafio da avaliação. Trad. Claudia Schilling e Fatima Murad. Porto Alegre: Artmed Editora, 2002.

RECUERO, R.. Redes sociais na internet. Porto Alegre: Sulina, 2009. 


\section{PROGRAMA "CONTA PRA MIM" E A (NÃO) FORMAÇÃO DE LEITORES}

Deisily de Quadros ${ }^{42}$ Flávia Brito Dias ${ }^{43}$

Resumo: O Programa "Conta pra mim" compõe a carteira da Política Nacional de Alfabetização (PNA), instituída pelo Decreto no 9.765 , de 11 de abril de 2019. O artigo tem como objetivo a ampla promoção da Literacia Familiar. Neste artigo, analisaremos o programa instituído pelo Governo Federal enquanto proposta de ação leitora, estabelecendo relações com pesquisas e teóricos que nos apresentam a realidade leitora no Brasil e a formação de leitores. Para tanto, elegemos como aporte teórico Silva (1985), Luckesi et al. (1991), Colomer e Camps (1996), Kleiman (2001), Jouve (2002), Bakthin (2003), Coracini (2005), Pszczol (2008), Alliende e Condemarín (2005), Klebis (2008), Cosson (2009), Zilberman (2009), Zilberman e Rösing (2009), Fernandes (2010), Chartier (2011), Larrosa (2002), Fernandes (2010), Paiva (2010), Wiezzel e Manzoni (2012), Souza e Lima (2012), e a complexidade com que se reveste essa formação à luz do olhar de Morin (2000).

Palavras-chave: Formação de leitores. Políticas de leitura. Conta Pra Mim.

\footnotetext{
42 Currículo Lattes: http://lattes.cnpq.br/7870169090904688.

${ }^{43}$ Currículo Lattes: http://lattes.cnpq.br/2318911813213511.
} 


\section{Introdução}

Durante décadas, e ainda hoje, pesquisadores e educadores renomados como Paulo Freire (1988), Marisa Lajolo (2004), Magda Soares (2003), Marisa Lajolo e Regina Zilberman (2001), dentre outros, preocupados com o que se observava no contexto escolar, denunciavam o viés em que perpassava a crise na escola brasileira, que se pautava em práticas pedagógicas e políticas públicas direcionadas à leitura ineficiente e que não alcançavam resultados pretendidos e/ou satisfatórios.

Sabemos que a leitura e a literatura são primordiais para a formação de sujeitos reflexivos, críticos, criativos, capazes de ler o mundo, como afirma Paulo Freire ${ }^{44}$ (1989). Em contrapartida, vivemos em um país de poucos leitores e que carece de políticas de leitura, de livros acessíveis, de bibliotecas e, com isso, de formação de leitores. É o que aponta a $5^{a}$ edição da pesquisa Retratos da Leitura no Brasil $^{45}$, quando nos traz a informação de que temos ainda $48 \%$ de não-leitores entre os brasileiros.

Nesse cenário de poucos leitores e de falta de interesse político pela formação de leitores, quando ouvimos a notícia de que o governo federal lança um projeto de leitura é motivo de comemoração. No entanto, nos deparamos com o programa Conta Pra Mim. Ao ler a proposta da Secretaria da Alfabetização, criada por meio do Decreto No 9.665, de 2 de janeiro de 2019, secretaria esta que faz parte da estrutura organizacional do Ministério da Educação (MEC), tomamos conhecimento de um programa que, em sua vertente, modifica histórias milenares de forma a utilizá-las com propósito moral.

\footnotetext{
${ }^{44}$ FREIRE, 1985. A importância do ato de ler em três artigos que se completam.

45 Pesquisa realizada pelo Instituto Pró-Livro, tem por objetivo analisar o comportamento leitor do Brasil, sendo, portanto, referência nos hábitos de leitura dos brasileiros.
} 
O programa Conta Pra Mim compõe a carteira da Política Nacional de Alfabetização (PNA), instituída pelo Decreto no 9.765 , de 11 de abril de 2019. Dentre outros programas que compõem tal política, Conta Pra Mim tem como objetivo a ampla promoção da Literacia Familiar.

Dessa forma, nossa intenção no presente artigo é analisar o programa enquanto proposta de ação leitora, estabelecendo relações com a realidade leitora no Brasil e a formação de leitores. Para tanto, elegemos como aporte teórico Silva (1985), Luckesi et al. (1991), Colomer e Camps (1996), Kleiman (2001), Jouve (2002), Bakthin (2003), Coracini (2005), Pszczol (2008), Alliende e Condemarín (2005), Klebis (2008), Cosson (2009), Zilberman (2009), Zilberman e Rösing (2009), Fernandes (2010), Chartier (2011), Larrosa (2002), Fernandes (2010), Paiva (2010), Wiezzel e Manzoni (2012), Souza e Lima (2012), e a complexidade com que se reveste essa formação à luz do olhar de Morin (2000).

\section{A realidade da formação leitora}

Ler é importante? A literatura deve ser acessível a todos? Provavelmente, se fizermos esses dois questionamentos em uma pesquisa, receberemos resposta afirmativa para as duas questões, ao menos de grande parte dos participantes. Dificilmente teremos pessoas discordando de que ler é imprescindível na sociedade e de que a literatura é importante para a formação do sujeito.

As práticas de leitura têm sido pensadas pelo viés da percepção e da análise dos discursos, do real por parte de um determinado grupo, como nos esclarece Chartier (1996), e, portanto, passa a ser peculiar de uma realidade social em um determinado período. 
Para Fernandes, "[...] a leitura constitui-se uma necessidade para todas as pessoas e um dos requisitos essenciais da cidadania" (2010, p. 550). Ou seja, é urgente formar leitores na nossa sociedade, o que ultrapassa o senso comum. É fato defendido por nomes de peso tanto no cenário brasileiro como mundial, como Pullin, que constata que "[...] de modo geral, os discursos oficiais que regulam a educação escolar brasileira, a saber, as diretrizes e os parâmetros curriculares para o ensino nos diversos níveis, têm proposto e justificado a necessidade da formação de leitores críticos" (2011, p. 15).

Isso porque a leitura, especialmente da literatura, é ação libertadora, que promove a reflexão, o estar e ser capaz de pensar o mundo a partir do diálogo com o outro, com o eu, com o meio, com o texto. Nessa perspectiva, Cosson (2014) considera que

[...] ler consiste em produzir sentidos por meio de um diálogo, um diálogo que travamos com o passado enquanto experiência do outro, experiência que compartilhamos e pela qual nos inserimos em determinada comunidade de leitores. Entendida dessa forma, a leitura é uma competência individual e social, um processo de produção de sentidos que envolve quatro elementos: o leitor, o autor, o texto e o contexto (COSSON, 2014, p. 36).

Dessa forma, quando falamos em leitura, não estamos mencionando algo subjetivo, mas uma ação dialógica que permite ao sujeito ter acesso ao que está ao seu entorno, ler o mundo, segundo a concepção freireana. Para Freire (1989), a leitura do mundo antecede a leitura da palavra. Mas essa leitura do mundo só se torna completa e se desvela ao sujeito quando há a leitura da palavra, a compreensão e reflexão do texto lido. A esse respeito, Marisa Lajolo afirma:

[...] entre tais coisas e tais outros incluem-se também livros e leitores, fecha-se o círculo: lê-se para entender o mundo, para viver melhor. Em nossa cultura, quanto mais abrangente a concepção de mundo e de vida, mais intensamente se lê, numa espiral quase sem fim, que pode e deve começar na escola, mas não pode (nem costuma) encerrar-se nela (LAJOLO, 2004, p. 7). 
Os desafios educacionais presentes na sociedade têm reverberado em discussões que se estendem além dos muros acadêmicos, perpassam por contextos políticos, sociais e culturais. 0 analfabetismo que se arrasta por séculos no país ainda salta aos olhos da sociedade em pleno século XXI e nunca se presenciou tamanha preocupação com a leitura e com o processo de formação de leitores como nas últimas décadas. Também se constata que o país tem à frente um grande número de analfabetos funcionais, como esclarece Failla, ao afirmar que

[...] se um quarto da população brasileira não compreende o que lê, não vamos conseguir avançar na formação leitora e na melhoria dos indicadores de leitura dos brasileiros sem que se garanta a alfabetização funcional aos alunos que cursam as primeiras séries do ensino fundamental e sem que se promova a compreensão leitora plena entre os nossos jovens que concluírem 0 ensino fundamental. Quem não consegue compreender uma frase que lê está condenado a não aprender qualquer disciplina ou conteúdo. A esse analfabeto funcional não está sendo garantido o direito de ler e compreender um parágrafo, quanto mais um texto ou um livro. (2016, p. 29)

Atualmente, diversos setores públicos e privados contam com a participação de institutos e organizações não governamentais para o desenvolvimento de ações e pesquisas em parceria com programas governamentais. Isso faz parte de uma perspectiva que visa a sanar as lacunas evidenciadas nos processos educativos brasileiros e ampliar as oportunidades de inclusão de uma grande camada da população brasileira, historicamente excluída, como também de ampliar os acessos à leitura e aos bens culturais.

Nessa vertente, o Instituto Pró-Livro lança a pesquisa Retratos da Leitura no Brasil, com padrão internacional de medição desenvolvida pelo CERLALC-UNESCO, viabilizando comparação com países da Ibero-América. Tais pesquisas decorrem da "[...] preocupação de especialistas de diferentes segmentos - das áreas de 
educação, cultura e produção e distribuição do livro - pelos níveis de leitura da população em geral e, em particular, dos jovens $[\ldots]^{\prime \prime}$, quando da criação desse Instituto, em 2006, como resposta aos resultados de estudos e conversação entre representantes do governo e entidades envolvidas na idealização, criação, produção e circulação do livro (INSTITUTO PRÓ-LIVRO, 2020).

A pesquisa tem o objetivo de diagnosticar como são e onde estão os leitores do Brasil, a fim de compreender as fragilidades, as expectativas e demandas que envolvem a formação do leitor. Seu intuito, conforme explica Failla (2016), é investigar sobre o comportamento leitor do brasileiro, como também diagnosticar os reflexos das políticas públicas, ações e investimentos advindos do governo e da sociedade civil, que visem fomentar a leitura e o acesso ao livro.

A quinta edição da pesquisa expõe como foco "identificar os hábitos dos brasileiros, especificamente em relação à Literatura" (INSTITUTO PRÓ-LIVRO, 2019). Esta amostra contou com 8.076 participantes, a fim de investigar o perfil do leitor de literatura - livro e outras plataformas. A pesquisa foi realidade em 208 municípios da população brasileira residente com 5 anos e mais, alfabetizada ou não.

Ao tecermos comparações com a pesquisa realizada na quarta edição (2016), a quinta edição, lançada em 2020, aponta que os índices apresentaram declínio no número de pessoas que declararamse leitores ${ }^{46}$, visto que em 2015 eles representavam $56 \%$ da população e, em 2019, eles somam 52\%, como ilustrados na Figura 1:

Figura 1: Comparativo de leitores e não leitores

\footnotetext{
46 De acordo com o Instituto Pró-livro (2020), considera-se leitor aquele que leu, inteiro ou em partes, pelo menos 1 livro nos últimos 3 meses.
} 


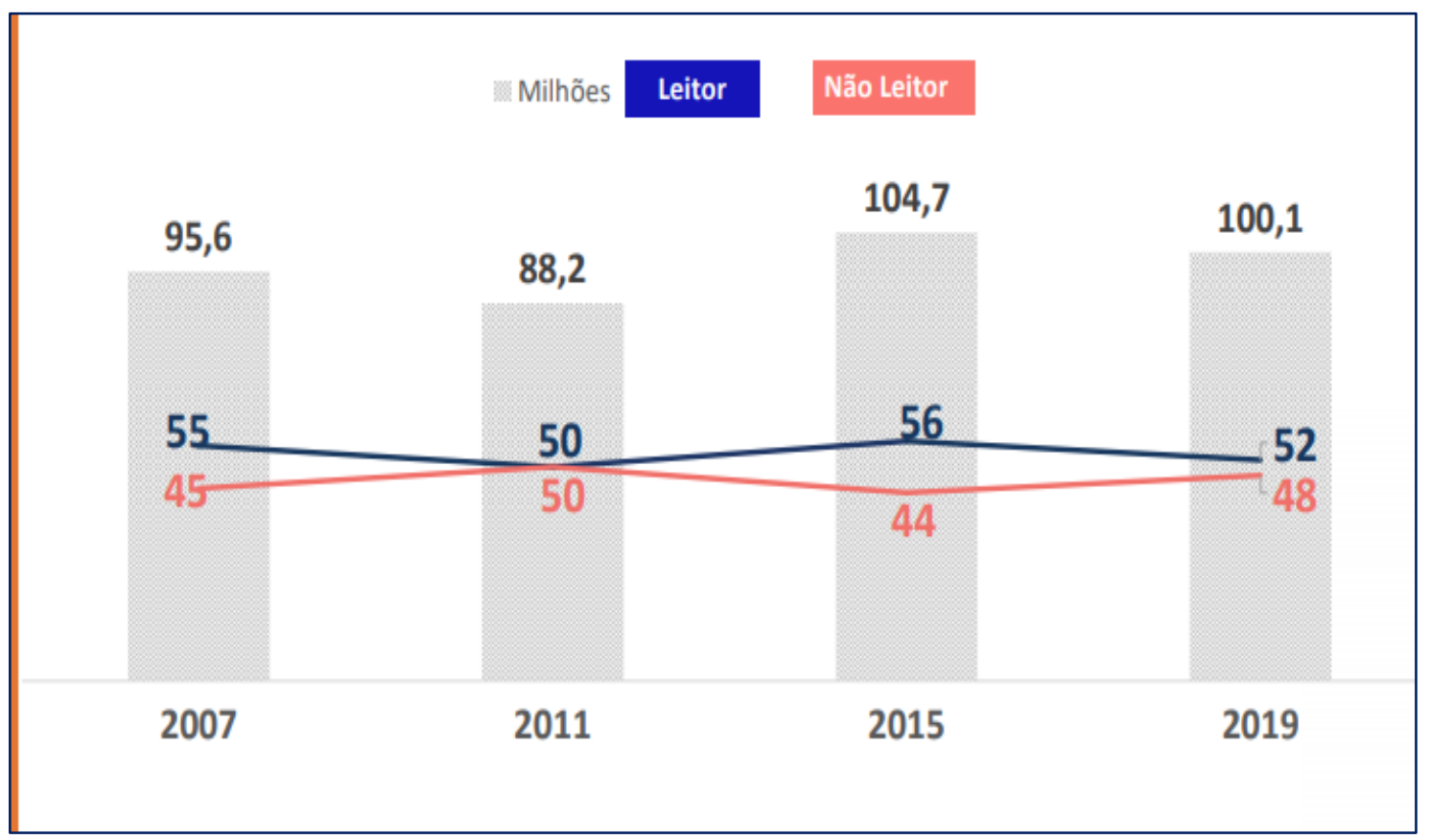

Fonte: Retratos da Leitura no Brasil (INSTITUTO PRÓ-LIVRO, 2020).

Ao nos determos nos comparativos dos sujeitos que se declaram não leitores ${ }^{47}$, observamos que a queda foi de 4 p.p. No entanto, com exceção dos dados elencados em 2011, o Brasil não conseguiu ultrapassar a linha dos $50 \%$ nos últimos sete anos. Sob a análise de Marques Neto (2016),

[...] apenas este dado já seria suficiente para demonstrar que vivemos uma trágica situação conjuntural que nos empurra, se não a mudarmos, para um destino cruel no mundo da informação e do conhecimento, ou seja, a de sermos sempre um país condenado a reproduzir o que outros povos mais preparados intelectualmente nos mandam fazer (MARQUES NETO, 2016, p. 69).

A pesquisa realizada em 2019 também aponta para outra observação significativa: mais de $80 \%$ dos sujeitos pesquisados estão inseridos em contextos escolares e declaram estar estudando, ou seja, a escola ainda é o agente responsável pela formação de leitores na atualidade, mesmo com todos os suportes tecnológicos presentes na

\footnotetext{
47 De acordo com o Instituto Pró-livro (2020), considera-se não leitor aquele que declarou não ter lido nenhum livro nos últimos 3 meses, mesmo que tenha lido nos últimos 12 meses.
} 
sociedade. Cabe destacar que apenas $42 \%$ dos entrevistados na pesquisa declararam estar fora da escola, não sendo estudantes neste contexto.

Sobre esse contexto, Abreu (1999) ressalta as repercussões pessoais e sociais (in)contáveis, tanto para o sujeito quanto para a comunidade, advindas da não frequência à escola. Contudo, o que se observa nesses cenários é a dificuldade em se formar leitores, não somente leitores institucionais, mas leitores para a vida e que, por diversos fatores, a leitura tem sido apresentada como um dos percalços tanto para a educação básica, quanto para a educação superior e, consequentemente, para a formação de futuros de leitores, cidadãos críticos inseridos na sociedade. É preciso que a formação de leitores seja um compromisso político e social.

Ao lançarmos um olhar para o nível de escolaridade de quem estuda, a pesquisa indica outros dados que merecem atenção: 86\% dos estudantes encontram-se nos anos iniciais do ensino fundamental e a mesma porcentagem encontra-se na educação superior. (FIGURA 2):

Figura 2: Nível de escolaridade dos estudantes - 2015 e 2019

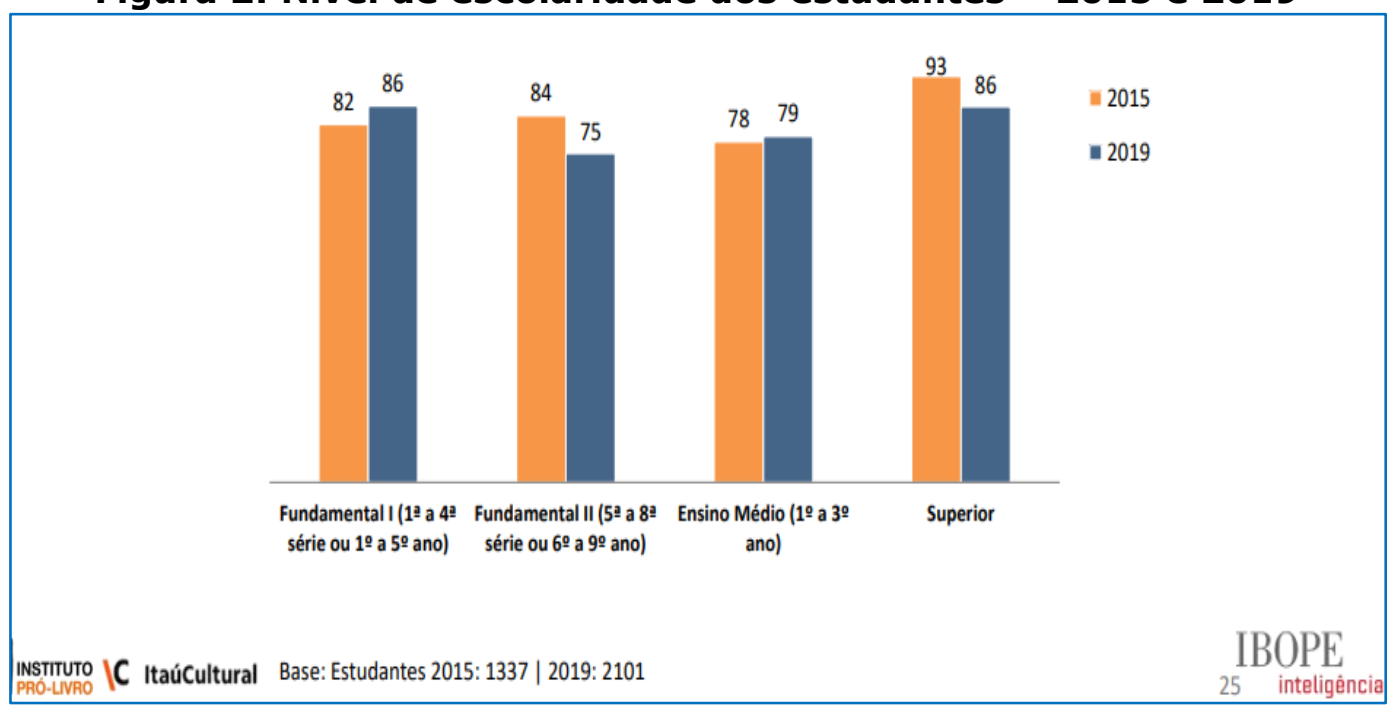

Fonte: Retratos da Leitura no Brasil (INSTITUTO PRÓ-LIVRO, 2020). 
Na análise de Paulino e Cosson (2009), o Brasil apresenta índices muito abaixo do esperado em níveis de proficiência em leitura, tanto no que se refere aos sujeitos inseridos nos espaços escolares, quanto aos sujeitos fora desse processo. Failla (2016), Silva (2009), Paulino e Cosson (2009) advertem que os pontos nevrálgicos destacados nos diagnósticos das pesquisas são reflexos da crise educacional, decorrentes de problemas históricos de concepções descontínuas entre o ensino e a aquisição das habilidades tanto para a escrita quanto para a leitura e dentre esta, a leitura literária.

No entanto, em se tratando de leitura literária, os dados da pesquisa Retratos da Leitura no Brasil apontam que, dentre os sujeitos da pesquisa, 2,28\% declaram-se leitores de literatura, desses, apenas $0,64 \%$ declararam ter lido livros na íntegra, $0,28 \%$ foram indicados pela escola (PRÓ-LIVRO, 2020).

Como esclarece Turchi (2009), mesmo diante das discussões e debates nacionais, essa demanda não parece estar esgotada, uma vez que os desafios relacionados às práticas de leitura no país ainda são muitos. Dada a importância da leitura para a formação integral do sujeito, todavia, entendemos que formar leitores na atualidade é um dos maiores desafios da educação.

Em relação a 2018, a OCDE divulgou, em 3 de dezembro de 2019, que $68,1 \%$ dos estudantes brasileiros, com 15 anos de idade, não possuem nível básico de matemática, para o exercício pleno da cidadania. Em ciências, o número chega a $55 \%$ e, em leitura, $50 \%$.

Os índices estão estagnados desde 2009. O Brasil tem baixa proficiência em leitura, matemática e ciências, se comparado com outros 78 países que participaram da avaliação (BRASIL, 2019b). 
Em relação à leitura, o Brasil ficou na faixa do ranking entre $55^{\mathrm{a}} \mathrm{e}$ 59a posição. A amostra brasileira contou com 10.961 estudantes, selecionados a partir de um total aproximado de 2 milhões, com cerca de 7 mil professores que também responderam aos questionários.

A avaliação foi aplicada eletronicamente, em maio de 2018, em 79 países nessa edição. Os resultados são indicadores especialmente quantitativos, que escalonam rankings entre os países membros da OCDE. Em leitura, os resultados dos estudantes, em 2009, 2012 e 2015 foram elencados em uma escala de sete níveis de proficiência (1b, 1a, 2, 3, 4, 5 e 6). Em 2018, passaram a ser oito níveis (1c, 1b, 1a, 2, 3, 4, 5 e 6), quando, de acordo com o Inep, e com base na OCDE, cerca de

[...] 50,0\% dos estudantes brasileiros alcançaram o Nível 2 ou acima em letramento em Leitura, em contraste a $77,4 \%$ dos estudantes dos países da OCDE. [... Nesse] Nível 2, os alunos começam a demonstrar a capacidade de usar suas habilidades de leitura para adquirir conhecimento e resolver uma ampla variedade de problemas práticos. Esse resultado, $[\ldots$ para a OCDE], provavelmente representa um grande obstáculo na vida desses jovens, dificultando ou até mesmo impedindo que avancem em seus estudos, tenham oportunidades melhores no mercado de trabalho e participem plenamente na sociedade. (BRASIL, 2019b, p. 69)

Frente a essa análise, a leitura aparece como ponto singular em discussões nos meios acadêmicos e em muitos debates nas políticas educacionais. Com o intuito de promover o acesso ao livro, à leitura, à literatura e às bibliotecas no Brasil, um conjunto de políticas, programas, projetos e ações contínuas são executadas pelo Estado e a Sociedade. A título de contextualização, citaremos o PROLER (1992), PNLL (2008; 2011), PNLD (2017) e PNLE (2019) e, recentemente, o

Conta pra Mim, programa de literacia familiar do Governo Federal.

\section{3 "Conta pra mim", ou não...}


Na contemporaneidade, o que se observa é uma reivindicação contínua da sociedade em relação à necessidade de uma melhor qualidade do ensino e uma preocupação de que sejam propostas mudanças no que os alunos aprendem e como devem ser ensinados. "Existe a expectativa de que os alunos apresentem desempenhos esperados e compatíveis com as diretrizes já propostas nas esferas estaduais, nacionais e mundiais" (PARISOTTO; PEREZ, 2012, p. 171).

Sob a portaria no 421, de 23 de abril de 2020, o governo federal institui o seu programa de literacia familiar, Conta pra Mim. Em seu art. 10, apresenta a "finalidade de orientar, estimular e promover práticas de literacia familiar em todo o território nacional" (BRASIL, 2020, p. 01). O programa visa fomentar o incentivo da leitura no âmbito familiar e esclarece, em seu art. $2^{\circ}$, que "é considerado públicoalvo do programa todas as famílias brasileiras, tendo prioridade aquelas em condição de vulnerabilidade socioeconômica" (BRASIL, 2020, p. 01). Destaca-se ainda em seu art. $3^{\circ}$, parágrafo três, a concepção de literacia familiar como "conjunto de práticas e experiências relacionadas com a linguagem, a leitura e a escrita, as quais a criança vivencia com seus pais ou cuidadores" (BRASIL, 2020, p. 01).

O programa apresenta um guia com orientações básicas e diretas para as famílias, direciona-se para o processo de alfabetização, com centralidade na prática linguística, o que vai de encontro com as concepções de Luckesi et al., ao esclarecer que

[...] a leitura ainda continua, com honrosas exceções, na linha do verbalismo, da repetição, da memorização e retenção de conteúdos, sem que os mesmos sejam submetidos a um processo crítico de avaliação, quer pelo confronto do que se leu com a realidade e informação vividas e possuídas pelos leitores, quer pela detectação do valor e da atualidade da própria mensagem transmitida. (1991, p. 133) 
Não desconsideramos que toda prática leitora é de singular importância para a formação do leitor, no entanto, questionamos o conceito de literacia trazido como cerne do programa que, de certo modo, não traz o protagonismo da literatura enquanto a arte da palavra. Questionamos o motivo pelo qual optaram pelo termo "literacia". A literatura parece ser vista com certa desconfiança, talvez por promover demasiada reflexão e convidar para questionamentos. Concebemos, sim, que a literatura, como ato leitor formativo, provoca, desconstrói, constrói, sensibiliza, não mobiliza.

Não localizamos, também no programa, aportes nas estratégias propostas que vinculem a formação leitora que propõe a construção de significados e pressupõe o envolvimento de processos complexos sendo, para Jouve, "uma atividade de várias facetas". (2002, p. 17)

A perspectiva que se lê na proposta do programa Conta pra Mim não concebe ou, de certo modo, não considera o leitor como protagonista do processo, como um sujeito ativo que, na experiência leitora, estabelece relações com diferentes habilidades, como a identificação e a memorização dos signos, a compreensão do que está escrito, a identificação afetiva com o texto, o confronto com outras leituras, dentre outras. Ao ler um texto, "o leitor faz dele parte de sua consciência e a ideia do autor passa a ser elemento de transformação, de ampliação de referências para o leitor [...]". (GIROTTO; LIMA; CHAVES, 2012, p. 103).

Ao concebermos a centralidade da leitura literária para a formação do leitor, comungamos com o olhar de Coelho, ao tecê-la "como arte, porém, ao assumir seu caráter transformador e direcionador, ela torna-se necessariamente formadora" (2000, p. 46) e não reguladora, como demonstra a proposta do programa.

O programa Conta pra Mim define como estratégia central que a leitura necessita ser mediada pela família e que deve ser procedida 
por discussão do conteúdo. Conteúdo este considerado "formativo" (grifos nossos) na perspectiva da transmissão de valores, condutas e regras. O projeto destaca que "as histórias infantis tendem a transmitir uma mensagem positiva, apresentando o valor das virtudes, dando conselhos ou ensinando regras de boa conduta" (REFERÊNCIA). E, nesse sentido, os contos de fadas tiveram seus enredos alterados.

Lendo as narrativas milenares no site do programa, observamos que João e Maria não foram abandonados pelos pais na floresta, devido ao pesadelo da fome que assolava a família; o lobo, em Chapeuzinho Vermelho, não foi morto pelo caçador, ele tropeça, cai no rio e se afoga; e as crianças foram omitidas do conto do flautista de Hamelin. Para Marina Colasanti,

[...] a poda selvagem realizada nos contos de fadas da coleção "Conta pra Mim", produção da Secretaria de Alfabetização, ligada ao MEC, parece gêmea daquela operada por Fenelon. Ele também achou que seria excelente ideia apropriar-se do repertório milenar, modificá-lo a seu modo, e utilizá-lo como exemplo moral. Ele também desvirtuou este patrimônio cultural, eliminando bruxas, fadas, qualquer aceno ao amor, ao erotismo e à violência (COLASANTI, 2021)

A poda se dá no conteúdo e também na omissão dos autores desses contos de fadas milenares. E por que é importante a criança leitora se deparar com abandono, fome, morte, crianças sequestradas, vingança? Porque essa é a vida real. A literatura tem o poder de auxiliar o pequeno leitor a (re)elaborar e administrar, por meio do imaginário e do simbólico, sentimentos e realidades diversas. Freud e Jung nos alertam sobre o poder estruturante da linguagem simbólica que atua no inconsciente, ajudando a criança a formular perguntas e obter respostas. 
Assim, essa poda de que nos fala Colasanti é uma censura que imprime o retrocesso de uma sociedade pensante. $E$ por que consideramos um retrocesso?

A leitura no Brasil, desde seus primórdios, nos faz transitar por histórias de fracasso de formação do sujeito crítico e do cidadão consciente. São linhas históricas que em seu cerne desvelam o processo de formação leitora advindo de propostas de descontinuidade e à constatação de propostas que não atendem à real necessidade do país. E que, dentre outras lacunas, apresenta índices altos de analfabetismo. Isso decorrente de que tais propostas advêm de políticas governamentais que têm sua origem na força e na dinâmica das forças que definem contextos e relações de poder de grupos econômicos, políticos e sociais, locais e internacionais (BONETTI, 2011).

Ao retomarmos a linha histórica da formação de leitores no Brasil, Luckesi et al. já indicam que "um rápido retrospecto histórico, a esse respeito, bastará para nos mostrar sua insuficiência e inautenticidade" (1991, p. 126). Considerada como discriminatória, a prática de leitura no Brasil iniciou pelas relações de poder, sobre a quem era permitido o acesso à leitura, inclusive a quem era destinada a sua proibição "[...] de gráficas, veiculação de impressos elaborados na colônia $[\ldots]$ a imprensa implantada, [...] não foi uma imprensa brasileira e sim uma imprensa real" (LUCKESI et al., 1991, p. 129), porém com controle das produções escritas.

Ao situar a leitura no final do século XX e início do século XXI, Valencia (2009) esclarece que em diversos países da Europa, principalmente na França, bem como nos Estado Unidos, despertaram um grande interesse em saber sobre os estados das práticas leitoras de seus cidadãos, estabelecendo-se como prioridades: a elevação da quantidade e qualidade das leituras, bem como deter o aumento do 
analfabetismo funcional, enfrentar por diversos meios a crise leitora e promover a leitura a todos os setores sociais, principalmente aos jovens.

Ao refletirem sobre a leitura dentro do contexto atual, Rivero e Gallo consideram que "as sociedades economicamente mais fortes exibem o alto nível de leitura de sua população como prova de superioridade cultural" (2004, p. 213). Diante dessa premissa, esses autores apontam que "as regiões mais pobres do planeta envergonham-se do baixo nível de leitura de seu povo e procuram democratizá-la através de programas emergenciais, combatendo constantemente o obscurantismo dos iletrados" (2014, p. 213).

Por esse viés, Alliende e Condemarín, em consonância com Riveiro e Gallo (2004), destacam a problemática de,

[...] nos países menos desenvolvidos, especificamente em vários países latino-americanos, a nova situação da leitura frente aos meios de comunicação de massas se traduz numa crise tanto dentro da escola, quanto fora dela. Dentro da escola, o ensino da leitura se torna mais difícil; aumenta o número de crianças que ao fim de dois anos ou mais anos de ensino ainda não sabem ler. Fora da escola, o hábito da leitura de livros, especialmente literários e científicos, decresce de forma notável. (2005, p. 11)

Frente a esse universo, Silva (2008) esclarece que no Brasil e em outros países latino-americanos muito tem se questionado sobre 0 protagonismo da leitura nos dias atuais. Não se pode negar que num país que é considerado como democrático, o acesso à leitura e à escrita seja um direito de todos e, sob essa perspectiva, a formação para a cidadania tem conexão direta com a aprendizagem e o aprimoramento da leitura.

Diante desse aspecto, Fernandes pondera que, "[...] na sociedade brasileira atual, a leitura constitui-se uma necessidade para 
todas as pessoas e um dos requisitos essenciais da cidadania" (2010, p. 550). Questionamos, no entanto, se um programa de apoio e incentivo à leitura, com a perspectiva de sanar o grave problema da alfabetização no Brasil, de todo modo, não deveria contar com a liberdade da leitura, com a formação do cidadão, sem o respaldo do controle conteudista? Ou um programa que indica em seu artigo 50 "a priorização de famílias em condição de vulnerabilidade socioeconômica" (BRASIL, 2020) apresenta características a considerar o contexto como um todo?

Frente a esse contexto, ponderamos que formar leitores na atualidade deva ir além de um processo conteudista, engessado, mas seguir na contramão desse processo, pois

[...] os caminhos que levam o leitor ao conhecimento e à crítica são, por assim dizer, inesperados, e admitir que o único caminho se abre nos umbrais das bibliotecas é negar o valor do conhecimento legítimo que se estabelece nas demais relações do homem em seus confrontos oprimido-opressor, em que a apropriação do bem cultural se impregna das visões de mundo daqueles que o detém e que podem, a partir do acesso a esse bem, recriá-lo, de acordo com suas necessidades e concepções (PAIVA, 2010, p. 527).

O processo de leitura não se resume ao caminho que leva ao livro, ou apenas a discursos que concebem a leitura de "historinhas bonitinhas" (grifos nossos) a fim de abordar "assuntos da família brasileira" (grifos nossos), como apresentado por autoridades na divulgação do programa Conta pra Mim.

Sob esse olhar, Espíndola, ao referir-se sobre o acesso à cultura escrita, esclarece que tal ação "pode produzir efeitos naqueles que têm acesso a ela, transformando-se, portanto, em instrumento de luta contra as desigualdades e, assim, permitindo (ou talvez contribuindo para) o acesso à cidadania" (2012, p. 33). A autora ainda acrescenta que "a possibilidade de ler e escrever situará o indivíduo diante das mais diversas possibilidades de leitura: desde as cotidianas, para 
resolver problemas do dia a dia, até as obras elaboradas por uma dada cultura $[\ldots]^{\prime \prime}(2012$, p. 33).

A experiência de leitura se dá em todos os momentos que se possam experimentar o ato de ler. Como defende Queirós, o processo que inicia à leitura,

[...] transcende $o$ ato simples de apresentar ao sujeito as letras que aí estão já escritas. É mais que preparar o leitor para a decifração das artimanhas de uma sociedade que pretende também consumi-lo. É mais que a incorporação de um saber frio, astutamente construído. Fundamental, ao pretender ensinar a leitura, é convocar o homem para tomar da sua palavra. Ter a palavra é, antes de tudo, munir-se para fazer-se menos indecifrável. Ler é cuidar-se rompendo com as grades do isolamento. Ler é evadir-se com o outro, sem, contudo, perder-se nas várias faces da palavra. Ler é encantar-se com as diferenças. (2012, p. 92)

Ademais, diferente das demais leituras, ${ }^{48}$ a leitura literária deve receber um olhar diferenciado nas instituições escolares, pois está destinada a que o leitor aprecie a expressão do autor que produz esse tipo de texto. Nesse sentido, em defesa da leitura de literatura, Espíndola refere-se a Candido ${ }^{49}$ (1995) para defender que: "o acesso à literatura, pode contribuir sobremaneira para a formação da cidadania, especialmente ao tratarmos disso como direito inalienável" (2012, p. 36).

A literatura (des)instala e possibilita que aconteçam outras formas de interação com o outro, para a sensibilização e experimentação de outras formas de realidade por meio do imaginário. Nesse sentido, Wiezzel e Manzoni consideram que "a Literatura, [...], abre um novo mundo, um mundo imaginário; legenda o mundo; faz o cidadão compreender direitos; tem o poder de transformar a realidade

\footnotetext{
48 Leituras: informativa, cognitiva, escapista (que envolve a satisfação no desejo em ler).

${ }^{49} \mathrm{Na}$ obra de CANDIDO, Antonio. O direito à literatura. In: CANDIDO, Antonio. Vários escritos. 3. ed. rev. e ampl. São Paulo: Ed. Duas Cidades, 1995. p. 235-263.
} 
da vida das pessoas[...]" (2012, p. 62). A literatura permite ao sujeito reconhecer-se enquanto indivíduo e que se modifique a leitura que ele faz do mundo.

Sendo assim, todo leitor deve ser percebido como um sujeito que pode circular com autonomia e criar, a partir de si, habilidades intelectuais e suas próprias interpretações para os textos que lê, sem as interferências e as abordagens de conteúdos previamente propostos.

Apesar da ação de transformar e criar novos sentidos para a realidade, no contexto atual, a leitura é apontada como uma das causas do fracasso escolar dos alunos. O que se percebe é que a leitura, dentro dos muros da escola, ainda se mantém como um processo mecânico. Nesse sentido, Colomer e Camps esclarecem que o equívoco das práticas educativas de leitura não tem como base a "perversidade intrínseca da escola, mas são consequências de uma concepção leitora que permaneceu vigente durante séculos, até que avanços teóricos nesse campo, nas últimas décadas, a puseram em questão" (1996, p. 29-30), mas nem por isso deixaram de ser uma situação crítica e desafiadora. Diante da realidade desse cenário desafiador, Silva esclarece que,

[...] no mais das vezes, a escola é livresca, mas sem livros e sem condições concretas para práticas de leitura pelos seus professores. Ainda não foi resolvida a questão de uma infraestrutura adequada que dê suporte objetivo aos professores nas atividades voltadas ao ensino e ao cultivo da leitura ao longo das séries escolares. Caminha-se pouco e lentamente em leitura no âmbito da educação escolarizada brasileira. (2008, p. 9)

Na contramão da proposta leitora do programa Conta pra Mim, ao se pretender caracterizar a leitura como uma atividade reflexiva e de conscientização para a formação de leitores, Silva (1985) adverte que existe a necessidade de se considerar alguns fatores e implicações, 
principalmente quando as relações são estabelecidas com organizações sociais específicas e concretas. O autor aponta que "[...] é preciso saber, neste caso, se a organização social, onde a leitura aparece e se localiza, dificulta ou facilita o surgimento de homens-leitores críticos e transformadores" (1985, p. 23).

Frente à análise proposta pelo Conta pra Mim, comungamos com a reflexão de Silva ao considerar que

[...] é preciso saber, ainda, se uma sociedade, através dos seus organismos dirigentes, concebe a leitura como uma atividade destinada à realização e ao bem-estar do povo ou como uma atividade que impede o surgimento da consciência e da racionalidade (1985, p. 23).

Silva ainda defende que "é preciso saber, enfim, se o objeto da leitura (livro ou similar) circula democraticamente numa sociedade de modo a permitir sua fruição por parte dos homens que constituem essa sociedade" (1985, p. 23). Para o autor, [...] "tais necessidades revelam que o problema da leitura não se desvincula de outros problemas enraizados em estrutura social" (1985, p. 23), sendo impossível descontextualizar vivências e carências leitoras das contradições que se fazem presentes na sociedade em que o indivíduo vive.

Como bem caracteriza Espíndola,

[...] uma sociedade que distribui de forma desigual os bens materiais irá também distribuir de forma desigual os bens culturais e, dentre estes, o acesso à alfabetização e à leitura, de modo que a luta pelo acesso aos bens culturais precisa, sobre maneira, estar vinculada à luta pelo acesso aos bens materiais $(2012$, p.16).

Sob os olhares críticos de Zilberman e Rösing, "[...] tudo o que mudou parece ter mudado para melhor - menos a escola, com suas 
consequências: a aprendizagem dos alunos, a situação do professor, as políticas públicas dirigidas à educação" (2009, p. 13).

Muitos são os desafios apresentados no cenário social para a formação de leitores. Porém, não se pode negar, como bem aponta Espíndola, sobre o acesso ao mundo da leitura, visto que este

[...] deve ser tratado como um direito por todo o país que se pretende democrático, ainda que uma democracia nos limites do que uma sociedade regida pelo modo capitalista de produção possa proporcionar (2012, p. 14).

O que se percebe é o viés provocativo das discussões, dentre outros problemas sintomáticos na educação brasileira, que dois dos protagonismos referem-se aos níveis insuficientes de leitura e à formação de leitores considerados pelas pesquisas realizadas no Brasil.

\section{Algumas considerações}

Refletir sobre o protagonismo da formação leitora exige que se perceba sua contingência a uma realidade, no caso, o cenário brasileiro, que tem como um de seus eixos centrais a necessidade de elevar o número de alfabetizados no país. Ao abordar a leitura como uma fonte de apropriação de significados e atribuição de sentidos para melhor percepção e leitura de mundo, cabe ressaltar a importância da formação de leitores, a qual Ihes possibilita sua inserção com uma formação intelectual, cultural, social e de tornarem-se sujeitos sociais que possam exercer seu papel enquanto cidadãos (SOUZA; LIMA, 2012).

Verifica-se que a formação de sujeitos leitores e de cidadãos reflexivos, críticos, criativos e solidários esbarra no contexto social, 
econômico e cultural brasileiro frente aos desafios relacionados à alfabetização e às práticas leitoras no Brasil, que nas últimas décadas têm sido debatidos. Estes, com pouca efetividade, como demonstram, por exemplo, os censos nacionais; as pesquisas e avaliações educacionais, entre elas Retratos de Leitura do Brasil (2020); os desempenhos insatisfatórios dos alunos, revelados pelo Sistema Nacional de Avaliação da Educação Básica (Saeb); o Programa Internacional de Avaliação de Estudantes (Pisa), os quais apontam uma dramática realidade em termos da prática leitora e a precária formação de um público leitor brasileiro.

Entendemos, de todo modo, as fragilidades, os percalços, os desafios em sanar as lacunas educacionais, bem como os pontos nevrálgicos que se referem à formação de leitores. Diante dos aspectos explorados, entendemos que as contribuições, fragilidades e os avanços priorizam a necessidade de melhorias a fim de promover reflexões e aproximar políticas educacionais efetivas em relação à formação de leitores.

No entanto, isso implica em adotar medidas que envolvam ir além de programas que objetivam contemplar "histórias bonitinhas" ou desenvolver estratégias que visem engessar conteúdos vinculados à valores morais. Enquanto cidadãos, nossos olhares não podem perder horizontes que visem "priorizar e investir na valorização e na qualificação do docente para o trabalho com a formação de leitores", promover reflexões e um processo de formação continuada que vise a melhoria da formação do leitor, qualificação de estratégias de leitura, melhor distribuição dos livros e acervos, além de "[...] envolver a sociedade civil nas ações das políticas públicas de leitura patrocinadas pelas diversas instâncias governamentais" (FERNANDES, 2010, p.567), estabelecendo, assim, parcerias com os professores. 
Ao comungar com as palavras de Paulo Freire, que encantadoramente escreve que "a leitura da palavra não é apenas precedida pela leitura do mundo, mas por uma certa forma de 'escrevêlo' ou de 're-escrevê-lo', quer dizer, de transformá-lo através de nossa prática consciente" (1984, p. 22) (Grifos das autoras), percebemos a importância de programas de leitura que concebam a literatura enquanto arte, enquanto libertação, enquanto atividade que exige a plena participação e interação do leitor, o que não é o caso do Conta pra Mim.

Freire, dessa forma, leva-nos a refletir sobre a questão: Que leitores queremos formar? Leitores circunstanciais, desvinculados do contexto e sem envolvimento ou queremos formar efetivamente leitores de mundo? Tais reflexões deveriam estar presentes nos cenários escolares e em evidência na sociedade e nas políticas educacionais e de leitura.

Muitos são os dilemas para a formação de leitores críticos, criativos e reflexivos, e muitos são os desafios enfrentados pela realidade do contexto escolar, social, econômico e cultural. Ainda assim, percebe-se um aumento na promoção de pesquisas, ações e experiências que possibilitem uma melhor garantia e efetividade para com o trabalho com a leitura, na busca da formação de leitores. Nesse sentido, confiemos nos projetos que não objetivam botar amarras na literatura e, consequentemente, em seus leitores.

Entretanto, tais discussões deveriam estar mais em evidência nos espaços acadêmicos, nos palcos das políticas educacionais, para que houvesse a efetividade de ações educativas na Educação Básica para a leitura e formação dos sujeitos leitores.

Frente a essas reflexões, acreditamos que nossas reflexões não se findam, cabe levá-los aos espaços acadêmicos e escolares a fim de 
promover um outro olhar frente a realidade que envolve a formação de leitores.

\section{REFERÊNCIAS}

ALLIENDE, F.; CONDEMARÍM, M.. A leitura: teoria, avaliação e desenvolvimento. Trad. Ernani Rosa. Porto Alegre: Artmed, 2005.

BRASIL. Ministério da Educação e da Cultura. Conta pra Mim. Disponível em: <http://alfabetizacao.mec.gov.br/contapramim>. Acesso em: 24 fev. 2021.

COELHO, N. N.. Literatura: arte, conhecimento e vida. São Paulo: Peiropolis, 2000.

COLASANTI, M.. Não conta pra mim. Disponível em: <https://www.marinacolasanti.com/2020/10/naoconta-pra-mim.html>. Acesso em: 24 fev. 2021.

COLOMER, T.; CAMPS, A.. Ensinar a ler, ensinar a escrever. São Paulo: Artmed, 1996.

COSSON, R.. Círculos de leitura e letramento literário. São Paulo: Contexto, 2014.

ESPÍNDOLA, A. L.. Leitura e Cidadania: O avesso do avesso. In: SOUZA, Renata Junqueira; LIMA, E. A. de. Leitura e cidadania: ações colaborativas e processos formativos. Campinas, SP: Mercado das Letras, 2012, p. 13-37.

FERnANDeS, P. V. N. D.. Políticas Públicas de Incentivo à Leitura: o caso do PROLER. Dissertação (Mestrado em Educação) - Universidade Federal do Recôncavo da Bahia. Centro de Artes, Humanidades e Letras. Cachoeira, BA, 2012. Disponível em: <http://www.dominiopublico.gov.br/pesquisa/DetalheObraForm.do?select_action=\&co>._Acesso em: 24 fev. 2021.

FERNANDES, C. R. D.. Convergências e tensões nas políticas públicas de leitura. In: FRADE, I. C. A. S. (Org.). Convergências e tensões no campo da formação e do trabalho docente. Belo Horizonte: Autêntica, 2010, p. 509-522.

FREIRE, P.. A importância do ato de ler. São Paulo: Cortez, 1985.

GIROTTO, C. G. G. S.; LIMA, E., A. de; CHAVES, M.. Eventos de Letramento Literário na Infância: o que as caixas contam... In: SOUZA, R. J.; LIMA, E. A. de. Leitura e cidadania: ações colaborativas e processos formativos. Campinas: Mercado das Letras, 2012, p.91-124.

INSTITUTO PRÓ-LIVRO: Retratos de leitura no Brasil. 3. ed. São Paulo: IPL, 2020.

LAJOLO, M.. Do mundo da leitura para a leitura do mundo. São Paulo: Ática, 2004.

LUCKESI, C. et. al. Fazer Universidade: Uma proposta metodológica. 6.ed. São Paulo: Cortez, 1991.

MAGNANI, M. do R. M.. Leitura, literatura e escola. 2. ed. São Paulo: Martins Fontes, 2001.

PULLIN, E. M.. Leitura: fenômeno pertinente para investigação no campo das representações sociais? In: X Congresso Nacional de Educação - EDUCERE e I Seminário Internacional de Representações Sociais, Subjetividade e Educação - SIRSSE. Anais. Curitiba: Pontifícia Universidade Católica do Paraná, 2011, p. 15814-15829. Disponível em: <www.educere.bruc.com.br/CD2011/pdf/5346_3747.pdf>. Acesso em: 14 ago. 2019.

PARISSOTTO, A. L. V.; PEREZ, M. de L. Z. T.. Formação Docente e Ensino de Leitura na Educação Fundamental. In: SOUZA, R. J.; LIMA, E. A. de. Leitura e cidadania: ações colaborativas e processos formativos. Campinas: Mercado das Letras, 2012, p.153-184.

QUEIRÓS, B. C.. O Livro é passaporte, é bilhete de partida. In: PRADO. J.; CÓNDINI, P.. A formação do leitor: pontos de vista. Rio de Janeiro: Argus, 1999, p. 23-24. 
RIVERO. C. M. L.; GALLO, S.. A formação de professores na sociedade do conhecimento. Bauru: Edusc, 2004

SILVA, E. T.. Elementos da pedagogia da leitura. São Paulo: Martins Fontes, 1988.

SILVA, E. T.. Leitura e realidade brasileira. 2. ed. Porto Alegre: Mercado Aberto, 1985.

SOUZA, R. J.; LIMA, E. A. de. Leitura e cidadania: ações colaborativas e processos formativos. Campinas: Mercado das Letras, 2012.

TURCHI, M. Z.. A formação do leitor literário. In: GOMES, C. M. (Org.). Língua e literatura: propostas de ensino. São Cristóvão: Ed. UFS, 2009. 


\title{
PODCASTS NA EDUCAÇÃO: CONTRIBUIÇÕES ACERCA DE UMA LINGUAGEM EMERGENTE
}

\author{
Douglas Mota Xavier de Lima50 \\ Rosiângela Campos Picanço ${ }^{51}$
}

Resumo: As tecnologias digitais de informação e comunicação (TDIC) têm transformado as diversas esferas da vida em sociedade. $\mathrm{Na}$ educação, a emergência dessas ferramentas torna-se ainda mais desafiadora, ao suscitar mudanças nas formas de ensinoaprendizagem e no acesso à informação, alterando ainda o ambiente de aprendizagem e as interações entre os estudantes e entre discentes e docentes. Nesse sentido, o presente trabalho objetiva expor algumas reflexões acerca do podcast, linguagem emergente e inclusiva que se apresenta como potencial recurso para a educação, tanto no Ensino Superior como na Educação Básica. Partindo das experiências alcançadas com a elaboração do Guia de tecnologias digitais e Ensino de História - Podcasts de História (2020), as discussões concentramse nos podcasts como recurso didático para a Educação Básica, temática que mobiliza diferentes questões que têm mobilizado os debates de educação nos últimos anos, como metodologias ativas, ensino híbrido, aprendizagem colaborativa e aprendizagem significativa. Com base na análise bibliográfica, o capítulo procura sistematizar apontamentos presentes em diferentes trabalhos de modo a subsidiar o uso dos podcasts nas salas de aula. Considerando que a maior parte dos estudos explora a criação de projetos educacionais de

\footnotetext{
${ }^{50}$ Currículo Lattes: http://lattes.cnpq.br/3484112840633429.

${ }^{51}$ Currículo Lattes: http://lattes.cnpq.br/2521531874608655.
} 
elaboração de programas podcast por estudantes, ao final do texto, apresentam-se algumas sugestões para tal elaboração.

Palavras-chave: Educação básica. Tecnologias digitais. Podcasts.

As transformações resultantes da revolução tecnológica das últimas décadas do século $X X$ mostram-se ainda mais presentes na atualidade, com a ampliação do acesso a dispositivos eletrônicos como notebooks, smartphones e tablets. Do mesmo modo, as relações sociais, mediadas pelas tecnologias digitais de informação e comunicação (TDIC), assumem um caráter de constante conectividade, a chamada sociedade da informação (CASTELLS, 2000), e inauguram o fenômeno da cibercultura (LÉVY, 1999). Nesse contexto, a passagem da Web 1.0 para a Web 2.0, uma transformação ocorrida no ciberespaço baseada nos princípios de colaboração, compartilhamento e interatividade, possibilitou a participação de todos os usuários no processo de criação desse mesmo ciberespaço (SILVA, 2014). Tal fenômeno manifesta-se, por exemplo, no surgimento do Youtube, em 2005, na ascensão de redes sociais como o Facebook (2004) e Instagram (2010), na criação de páginas na internet sobre múltiplos assuntos, nas redes de informação colaborativa, como a Wikipédia, e nos serviços de "computação em nuvem" (cloud computer), de onde derivam plataformas de streaming de vídeo, como Netflix, Amazon Prime e Disney+.

A educação não ficou alijada dos impactos dessas tecnologias digitais, o que tem suscitado mudanças nas formas de aprendizagem e no acesso à informação. Pode-se, inclusive, compreender que a revolução tecnológica resultou no advento de uma geração classificada como homo zappiens (VEEN, VRAKKING, 2009), ou denominada de "nativos digitais" (PRENSKY, 2001), criando ainda demandas de 
diferentes ordens, as quais, em geral, colocam em xeque as estratégias de ensino e aprendizagem calcadas nos moldes tradicionais. Nesse sentido, as tecnologias digitais podem ser utilizadas na educação para melhorar o desempenho do que já existe - auxiliando o professor na organização de materiais e na ilustração de conteúdo - e podem propiciar a criação de espaços e atividades dentro da instituição de ensino, como o uso de vídeos nas aulas e o desenvolvimento de atividades em laboratórios de informática ou ambientes virtuais (MORAN, 2012). Em síntese, as tecnologias digitais têm fomentado novas práticas educacionais, tanto repensando o espaço de aprendizagem como enfatizando práticas de cooperação e interação entre os estudantes e entre discentes e docentes.

Partindo desses pressupostos e das demandas frequentemente relatadas pelos alunos no ambiente de sala de aula - dificuldade de acesso à internet, uso constante do celular/smartphone para as atividades acadêmicas, falta de recursos em vídeo e áudio sobre o conteúdo das disciplinas etc. -, criamos um projeto de ensino no curso de Licenciatura em História da Universidade Federal do Oeste do Pará voltado para a aprendizagem por meio de dispositivos móveis (mobile learning) e, como primeira ação do projeto, concentramos a atenção nos podcasts. Entre 2019 e 2020, o primeiro resultado do projeto foi a elaboração do Guia de tecnologias digitais e Ensino de História Podcasts de História (LIMA; PICANÇO, 2020), material focado no uso de podcasts como recurso didático no ensino superior de História. Ao redigir o presente capítulo, cerca de um ano depois do lançamento do guia, muitas mudanças se apresentaram.

Desde a publicação, não imaginávamos o rápido e surpreendente avanço da questão das tecnologias digitais e, em particular, dos podcasts na educação. Tal crescimento foi motivado, sobretudo, pelas novas demandas geradas pela pandemia da Covid-19, que levou todos 
os níveis da educação a migrar do ensino presencial para o modelo remoto, fomentando ainda a elaboração de novos recursos de ensino. Em poucos meses, termos como atividades síncronas e assíncronas, ensino híbrido, aprendizagem digital, avaliação on-line, entre outros, entraram no vocabulário dos educadores brasileiros, da Educação Básica ao Ensino Superior. Destarte, considerando as experiências adquiridas com a pesquisa sobre podcast no ensino superior e a atualidade da temática no cenário educacional brasileiro, propomos no presente capítulo refletir sobre outro eixo de inserção desse recurso, questão até então secundária em nossas produções, o uso de podcasts na educação básica.

\section{Sobre os podcasts}

O podcast surgiu a partir da fusão do Ipod (aparelho produzido pela Apple que reproduz arquivos de áudio em formato .mp3) e o Broadcast (transmissão). Pode ser definido como um material de áudio gravado nas extensões .mp3, .ogg ou .mp4, formatos digitais que permitem armazenar músicas e outros arquivos de áudio num espaço relativamente pequeno, além de estar anexado a um feed RSS (arquivo de informação) que permite que se assinem os programas recebendo as informações sem precisar ir ao site do produtor (BARROS; MENTA, 2007).

Nesse sentido, outra característica marcante que o diferencia de outros materiais em formato áudio é o sistema de pull e push, o qual permite aos usuários maior liberdade de escolha em relação ao conteúdo de sua preferência, ao possibilitar a seleção dos programas preferidos sem depender de conteúdos previstos em uma grade de programação (SOUZA, 2017). Essa funcionalidade, que permite ao 
usuário selecionar o conteúdo de sua preferência, difere os podcasts dos programas de rádio tradicionais, sendo um atrativo a mais para o público em expansão da podosfera - termo para o amplo espaço digital onde os podcasts são disponibilizados -, além de criar a possibilidade de escutar o conteúdo on-line ou fazer o download do arquivo que pode ser apreciado no tempo livre dos ouvintes. Cada podcast disponibilizado na podosfera é chamado de episódio, seus criadores são denominados de podcaster e os programas podem ter periodicidades variadas: diários, semanais, quinzenais ou mensais, e sua duração pode variar entre poucos minutos a mais de uma hora.

Destarte, as diferentes características que a mídia podcast possui exibe o seu caráter democrático, estando ela mesma ligada ao processo de democratização do acesso à internet e as transformações da Web 2.0, no qual a relação entre criadores e consumidores na internet mudou. Tal condição possibilitou a facilidade de acesso e uma maior inclusão digital, em que o podcast ganha notoriedade a partir das possibilidades de criação de uma proposta de conteúdos que gerem identificação e engajamento dos mais diferentes públicos ouvintes. Desse modo, como afirmam Silva e Silva: "Pessoas comuns, profissionais de comunicação e instituições de ensino perceberam as possibilidades de contato de difusão de entretenimento e informação por meio um formato que permite criar identificação e, também, proximidade entre os públicos." (2017, p. 265).

A produção de podcast no Brasil e no mundo ganha a atenção de grupos ligados à comunicação, como as grandes empresas que trabalham na produção de conteúdos digitais, e da iniciativa independente de profissionais das mais variadas áreas, interessados em compartilhar os interesses de suas comunidades, o que faz que a podosfera tenha um rico leque de temáticas variadas. Ademais, alguns programas fazem tanto sucesso que apresentam uma característica já 
demostrada no Youtube, outra plataforma de produção de conteúdo em que os programas alcançam a capacidade de gerar engajamento do público, o que pode ser chamado de "habilidade de fidelizar uma comunidade de telespectadores/ouvintes/seguidores" (SILVA; SILVA, 2017, p. 263).

Desde 2019, segundo dados de pesquisas realizadas pelos principais agregadores ${ }^{52}$ do mercado, é possível identificar o chamado boom dos podcasts no Brasil. Os dados disponibilizados pelo Spotify indicam que, entre 2017 e 2018 , houve aumento de $330 \%{ }^{53}$ no número médio de ouvintes mundiais de podcasts diários na plataforma, crescimento que levou a empresa a investir na criação de uma ferramenta de gerenciamento para os produtores de podcasts ${ }^{54}$ e aumentar a sua participação em mercados emergentes como o brasileiro. O Deezer igualmente contabilizou um aumento de $40 \%$ no consumo de podcasts e, desde 2017, passou a investir em conteúdos originais em parceria com terceiros. No Brasil, a plataforma registrou um crescimento de 67\%, em 2019. ${ }^{55}$

Corroborando com esses dados, uma pesquisa realizada pelo Ibope em maio de 2019, que contou com a entrevista de duas mil pessoas, revelou que os ouvintes mais assíduos dos podcasts são jovens de 16 a 24 anos e que o principal dispositivo eletrônico utilizado para a escuta é o smartphone, representado por $75 \%$ de preferência. ${ }^{56}$ Por fim, segundo resultados de 2018 obtidos no maior estudo sobre a

\footnotetext{
52 Os agregadores de podcast são aplicativos e/ou sites que armazenam e transmitem arquivos de áudio. Eles permitem que o usuário consiga acessar, ouvir e baixar o podcast seja no computador, seja no smartphone. A maioria dos agregadores requer a utilização de outro site ou aplicativo capaz de, primeiramente, hospedar o podcast. Sem hospedar o áudio em alguma plataforma própria para isso, não é possível compartilhá-lo no agregador de podcast, tampouco nas redes sociais.

53 Disponível em: <https://oglobo.globo.com/cultura/a-era-de-ouro-dos-podcasts-entenda-boom-dosprogramas-de-audio-on-line-23612273>. Acesso em: 07 de março de 2020.

54 Disponível em:< https://www.uol.com.br/tilt/noticias/redacao/2019/08/20/2019-e-o-ano-dospodcasts-no-brasil.htm>. Acesso em: 07 de março de 2020.

55 Disponível em: <https://www.uol.com.br/tilt/noticias/redacao/2019/10/21/impulsionado-porstreaming-consumo-de-podcast-cresce-67-no-brasil-em-2019.htm>. Acesso em: 07 de março de 2020.

56 Disponível em: <https://www.uol.com.br/tilt/noticias/redacao/2019/10/21/impulsionado-porstreaming-consumo-de-podcast-cresce-67-no-brasil-em-2019.htm>. Acesso em: 07 de março de 2020.
} 
podosfera brasileira, a Podpequisa, ${ }^{57}$ que contou com 22 mil entrevistas, História é o terceiro assunto de maior preferência pelos ouvintes entrevistados, representando cerca de 52,6\%.

Por meio do mapeamento publicado no Guia de Tecnologias digitais (LIMA; PICANÇO, 2020), constatamos duas características interligadas em relação ao desenvolvimento recente de programas dedicados à História. Primeiramente, o significativo crescimento da oferta de podcasts relacionados aos temas históricos, aumento acompanhado de uma importante variação de formato, isto é, aos tradicionais programas voltados ao entretenimento e ao público em geral, por vezes apresentando conversas informais e não especializadas ou tendo a História como um entre vários temas. A exemplo disso, aos podcasts "Sci-Cast", um dos mais antigos podcasts brasileiros relacionados a diferentes temáticas; "Buenas ideias", do jornalista Eduardo Bueno; e "História no Cast", idealizado pelo historiador Leandro Marin e voltado à relação entre História e Cultura Pop, somaram-se inúmeros programas dedicados a divulgação de pesquisas acadêmicas - como exemplo, "Diálogos Olimpianos", podcast produzido pelo Grupo de Estudos sobre o Mundo Antigo Mediterrânico (GEMAM), da Universidade Federal de Santa Maria; e o "Podcast da Esboços", programa criado para ampliar a compreensão dos artigos publicados na revista "Esboços: histórias em contextos globais".

Em segundo lugar, observam-se mudanças em relação à autoria/produção dos programas. As universidades ampliam a sua inserção extensionista, alcançando o meio digital e produzindo programas podcasts, seja a partir dos grupos de estudos, laboratórios de pesquisa, projetos de extensão e programas de Pós-Graduação, em

\footnotetext{
57 Disponível em: <http://abpod.com.br/podpesquisa/>. Acesso em: 07 de março de 2020.
} 
que um determinado grupo vê nessa ferramenta um espaço de comunicação e compartilhamento do conhecimento científico produzido; e, paralelamente, com a produção de podcasts como resultado da iniciativa de profissionais não institucionalizados, que buscam na podosfera novas perspectivas de inserção profissional. Essa produção 'independente' ou 'autônoma', seja da área de História ou de outras áreas do conhecimento, representa uma parcela significativa dos podcasters no Brasil, os quais produzem sem o patrocínio de empresas ou sem aportes financeiros externos prévios. De certo modo, conforme Pacelli, mesmo com poucos recursos, tais produtores desenvolvem seus programas de maneira relativamente livre e criativa, contribuindo para a divulgação democrática do conhecimento:

Os podcasts no Brasil atuam como amplificadores de vozes costumeiramente ignoradas. Em grande medida produzidos alheios à lógica do lucro financeiro e atentos ao interesse espontâneo, acabam preenchendo um espaço educativo de exposição e discussão de temas pouco veiculados ou inexistentes em outros âmbitos: na grande mídia, no dia a dia social ou mesmo na escola. (FREIRE, 2013, p. 104)

A diversidade de temáticas tratadas, como Educação, Política, Notícias, Esportes, História, Mundo Nerd, Cinema, Curiosidades etc., assim como a quantidade considerável de programas podcast disponíveis gratuitamente na rede têm suscitado o interesse de estudiosos em torno do potencial pedagógico desse conteúdo na educação. Além disso, a variedade de temáticas abordadas tende a evidenciar a pluralidade do público que esse formato de mídia pode alcançar, entre eles os estudantes, que desde o Ensino Fundamental até o Ensino Superior cada vez mais acessam podcasts para entretenimento ou como recurso de estudo. Nesse viés, considerar a presença emergente de conteúdos na internet com fins educativos, como os vídeos, imagens e os podcasts, faz-se uma tarefa necessária 
na busca de repensar as estratégias de ensino e aprendizagem articuladas com as tecnologias digitais. Tal tendência, por exemplo, se expressa na Base Nacional Comum Curricular (BNCC), que enfatiza o protagonismo estudantil, o uso e a criação de conteúdos críticos e éticos para a promoção de uma sociedade democrática e inclusiva.

\title{
Podcasts na Educação básica
}

De acordo com a historiadora Helenice Rocha:

\begin{abstract}
Desde o final da década de 1980 as linguagens vêm ganhando destaque em publicações sobre o ensino de história no Brasil. Sob a denominação de "linguagens" ou "novas linguagens", o olhar do professor e do pesquisador do ensino de história vem se voltando para alternativas à tradicional e tão criticada exposição didática oral, presente nas aulas de história. (ROCHA, 2005, p. 97)
\end{abstract}

Os apontamentos que abrem o capítulo de Rocha são referentes ao campo da História, mas também são válidos para outras áreas da Educação. Como indicado pela autora, nas últimas décadas a questão das linguagens têm mobilizado diferentes educadores na busca de superar modelos tradicionais de ensino e aprendizagem. Sob tal eixo, por vezes encarados como recursos didáticos a serem usados pelo professor, inserem-se na educação básica discussões sobre televisão, cinema, quadrinhos, rádio, jogos eletrônicos, tecnologias digitais, entre outras. Paralelamente, no sentido de competências a serem apreendidas pelo estudante, são igualmente constantes estudos mais amplos acerca da promoção de diferentes linguagens no ensino, os quais tratam de uma aprendizagem que articule a linguagem oral, textual, audiovisual e a digital. A linguagem digital é a mais recente e, provavelmente, a mais demandada pela atualidade, evidenciando e 
aprofundando discussões travadas há décadas sobre a necessidade de uma educação para as mídias (BÉVORT; BELLONI, 2009; BUCKINGHAM, 2010).

É nesse duplo sentido, isto é, como um recurso do professor e como uma linguagem digital a ser apreendida pelo estudante, que passaremos a tratar de caminhos para o trabalho com podcasts na educação básica. Nossa proposta é tentar sistematizar apontamentos presentes em diferentes trabalhos de modo a contribuir para a promoção dessa linguagem emergente no ensino básico.

Como ponto de partida, constata-se que a pesquisa sobre podcasts no Brasil é deveras recente, tal como a própria mídia, visto que o primeiro podcast brasileiro data de 2004. Consequentemente, nota-se o seu pouco enraizamento no meio acadêmico, mesmo que os dados disponíveis indiquem um claro movimento de crescimento em diferentes áreas. Exemplifica isso o levantamento realizado no Catálogo de Teses e Dissertações da CAPES, que identificou 64 estudos produzidos entre 2007 e 2019 (Figura 1). Desses, poucos são das áreas de Educação (9) e Ensino (7), evidenciando que o maior volume de investigações sobre podcasts no meio acadêmico não é ligado ao grande campo da Educação. 
Figura 1. Teses e Dissertações brasileiras sobre Podcasts (2007-2019)

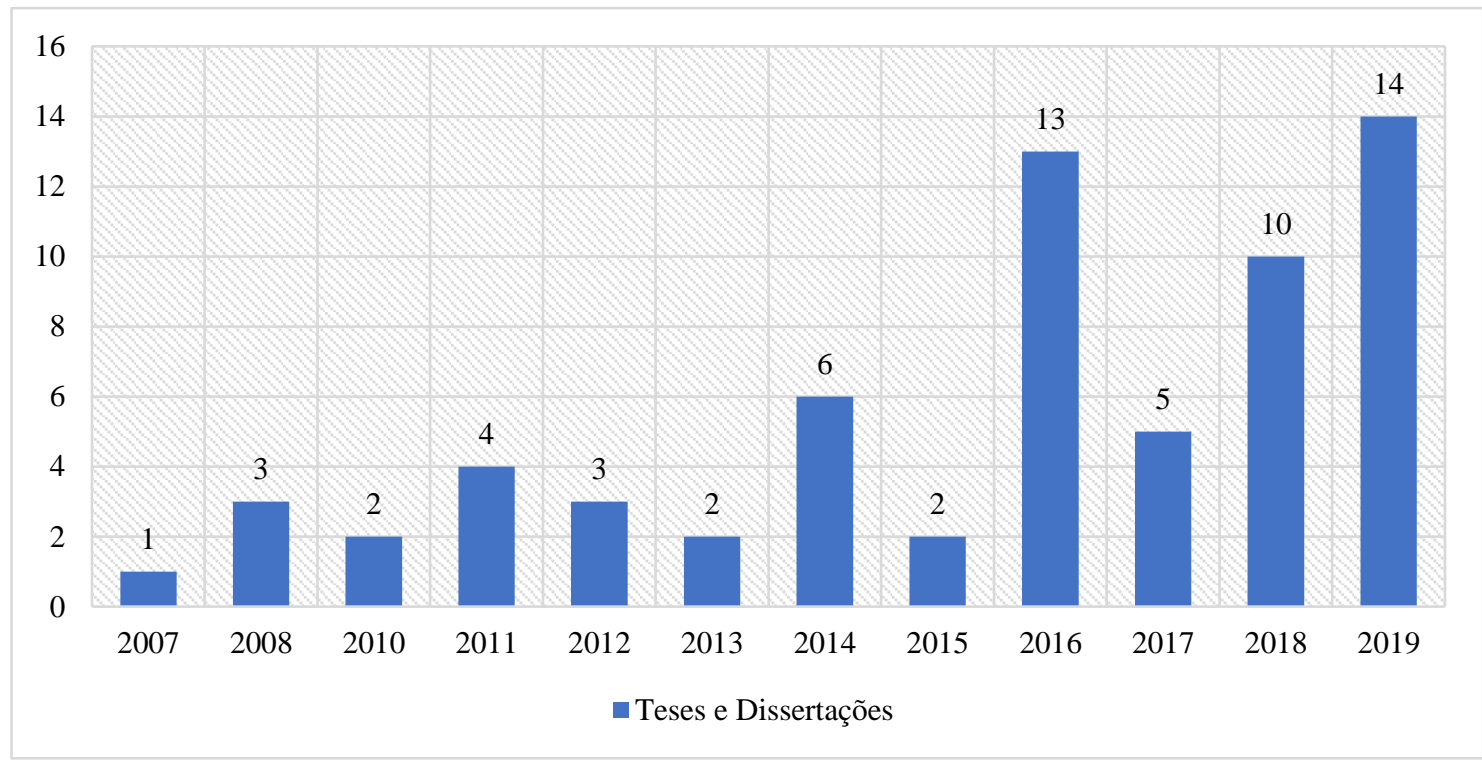

Fonte: Catálogo de Teses e Dissertações da CAPES (https://catalogodeteses.capes.gov.br)

Destarte, as principais contribuições sobre o uso de podcasts na educação encontram-se dispersas em artigos e capítulos. Um dos eixos transversais sobre o tema é a questão da inclusão, sobretudo de estudantes com deficiência visual. Nesse sentido, o podcast é encarado como ferramenta educativa inclusiva, capaz de ampliar o acesso a conteúdos e possibilitar o vínculo afetivo e efetivo entre o estudante e o material (FREIRE, 2011; BOTTENTUIT JÚNIOR; COUTINHO, 2009).

Não obstante, o principal aporte sobre a temática relaciona-se a trabalhos de implementação dos podcasts nos espaços de aprendizagem, mediada por uma dinâmica voltada à criação de programas por educadores e educandos. Exemplificando esse eixo, o artigo de Barros e Menta (2007) apresenta um dos primeiros projetos no Brasil voltados para a produção de áudios para a educação, o projeto PodEscola, uma iniciativa que entre janeiro e maio de 2006 
buscou a criação de um podcast com fins educativos por alunos e professores. Segundo o relato, o programa trabalhou com conceitos e reflexões acerca de direitos autorais e direitos morais, sobretudo no que diz respeito aos direitos autorais na internet, além da noção de ética frente ao trabalho colaborativo. No decorrer do artigo os autores fazem considerações teóricas sobre potencial do podcast para a educação, indicando ainda as dificuldades encontradas para a implementação e criação do programa, sobretudo as de ordem técnica.

Pode-se afirmar que a questão da produção de podcasts por estudantes estabelece relações com diferentes temáticas, como o Ensino híbrido, as Metodologias Ativas, a Aprendizagem Significativa e a Aprendizagem Colaborativa (Figura 2). Tal trabalho abarca uma dupla inclusão, a inclusão digital e a inclusão sociodigital; estimula o protagonismo estudantil, promove o pensamento crítico, a criatividade e a cidadania; permite a introdução de debates sobre direitos e deveres e sobre ética; e alcança a discussão sobre informação fidedigna, algo urgente frente às fake News que constantemente circulam nas redes sociais. 
Figura 2. Dimensões relacionadas à produção de podcast na educação

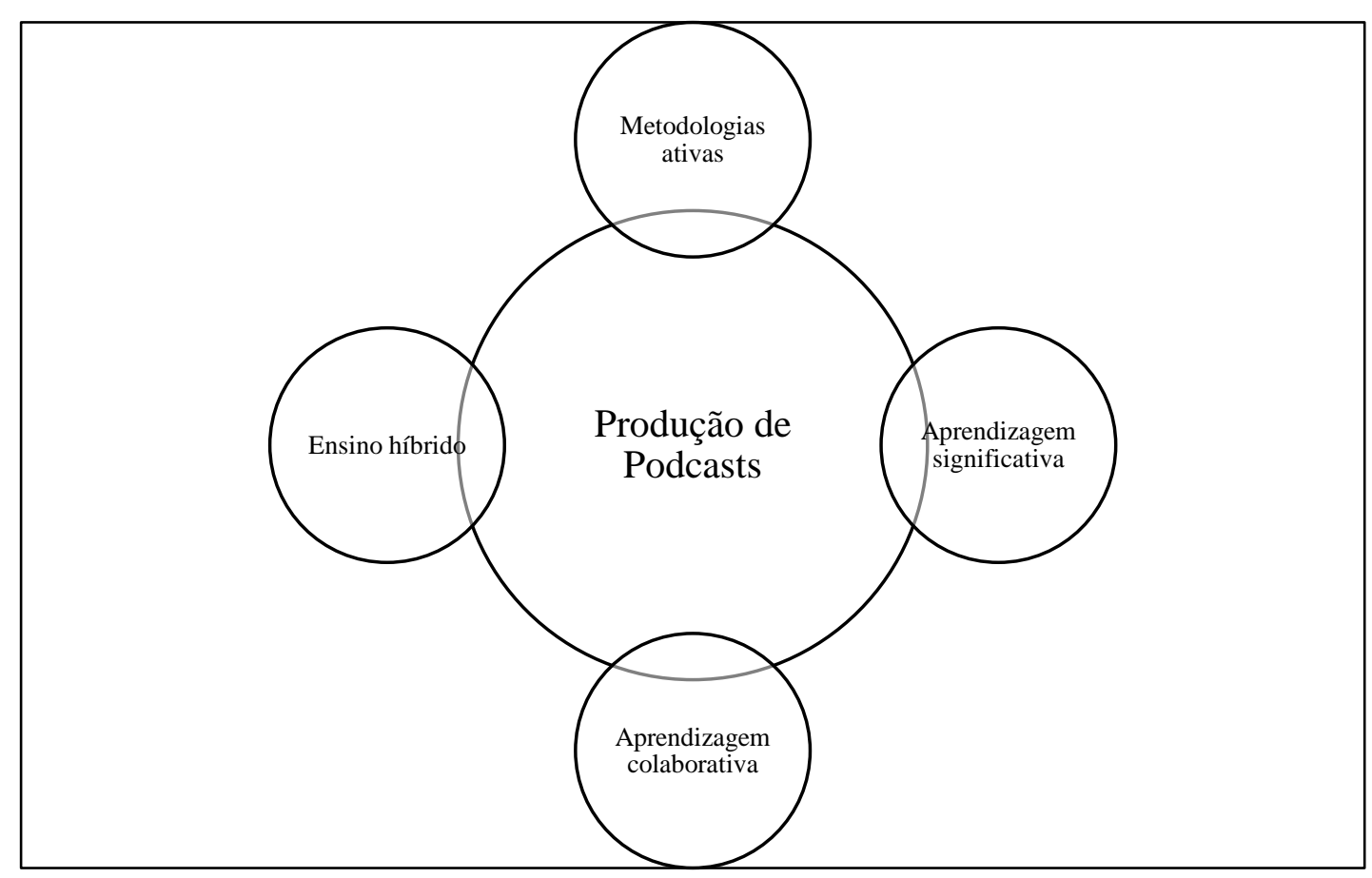

Fonte: Elaboração própria

Inserindo-se nesse eixo da produção de podcasts, podem ser propostas atividades de radionovelas, dramatização, construção de narrativas diversas, pesquisa temática, debate e audiodescrição. Em todos os casos, observa-se a mobilização constante dos elementos da figura 2, articulando protagonismo estudantil e inclusão digital.

Apesar disso, são comuns relatos de professores que não sabem como começar a estruturar um projeto de produção de podcast junto 
aos alunos ou, como indicado por Barros e Menta (2007), esbarram nas questões técnicas. Nesse sentido, para finalizar os presentes apontamentos, passamos a indicar alguns caminhos para a produção de podcasts na educação básica.

\section{Produção de podcasts}

Como sugestão de organização da atividade, entendemos que um projeto de elaboração de podcasts passa centralmente por duas ações: primeiramente, pela definição do tema a ser abordado, que pode envolver atualidades, temáticas disciplinares e interdisciplinares ou questões ligadas à comunidade escolar; em seguida, é importante a elaboração do roteiro (apresentação do tema, desenvolvimento e conclusões), o que necessariamente promove atividade de pesquisa colaborativa pelos alunos e permite que o docente oriente a investigação e discuta junto aos estudantes a relevância de fontes confiáveis de informação. Feitos esses passos, a sequência da atividade envolve a gravação, edição e divulgação do material, ações que oportunizam o trabalho coletivo e a interação entre os alunos.

Em linhas gerais, é essa fase final da elaboração do podcast que mais assusta os interessados em começar projetos com tal mídia. Assim, ao tratar das barreiras e limitações para a produção e uso de podcast na educação alguns problemas são recorrentemente citados: dificuldades de acesso à internet; limitações técnicas para gravação, edição e disponibilização; insuficiência de dispositivos e equipamentos. A identificação de tais problemas, tão comuns em diferentes realidades do Brasil, de certo modo contribui para o necessário debate acerca da democratização do acesso à informação, discussão que abarca questões como softwares livres, internet banda larga aberta (gratuita) 
etc. Não obstante, a produção de podcasts pode ser realizada com poucos recursos e sem acesso à internet durante a maior parte do processo, demandando para início do trabalho um gravador ou um dispositivo com gravador - algo generalizado nos celulares e smartphones. Sugere-se, comumente, que a gravação ocorra num ambiente fechado e o mais silencioso o possível, cuidando para que as falas ocorram perto do microfone - do gravador ou do dispositivo escolhido - e de forma pausada, podendo ainda ser realizadas diretamente em plataformas virtuais de videoconferência.

Em termos de elementos técnicos, como edição (cortes, redução de ruídos, vinheta, trilha e demais efeitos sonoros etc.) e divulgação na internet, existem diversos softwares e sites com conteúdo gratuitos que podem auxiliar o docente na montagem do projeto educativo ou diretamente os estudantes na elaboração dos programas. Esse é o caso de programas como o Audacity, para edição, o SoundCloud, o Anchor e o Spreaker, para disponibilização do conteúdo, ou ainda a biblioteca de áudio do Youtube com milhares de efeitos sonoros e músicas gratuitas.

\section{Considerações finais}

Gostaríamos de finalizar a presente reflexão remetendo aos apontamentos de José Manuel Moran sobre as tecnologias:

As tecnologias evoluem muito mais rapidamente do que a cultura. A cultura implica padrões, repetição, consolidação. A cultura educacional também. As tecnologias permitem mudanças profundas, que praticamente permanecem inexploradas, em virtude da inércia da cultura tradicional, do medo, dos valores consolidados. Por isso, sempre haverá um distanciamento entre as possibilidades e a realidade. $O$ ser humano avança com inúmeras contradições, muito mais 
devagar que os costumes, hábitos, valores. Intelectualmente, também avançamos muito mais do que na prática. Há sempre um distanciamento grande entre o desejo e a ação. Apesar de tudo, está-se construindo uma sociedade que, em uma ou duas décadas, será muito diferente da que vivemos." (MORAN, 2012, p. 146)

Essa sociedade diferente e cada vez mais marcada pelas tecnologias digitais está em pleno desenvolvimento, processo acelerado desde $2020 \mathrm{com}$ a pandemia da COVID-19 que, no contexto de escrita deste capítulo, ainda não dá sinais de término. Nesse cenário, consideramos que cabe aos profissionais da educação (re)pensar suas práticas de ensino e aprendizagem de modo a responder demandas que se acumulam e superar as barreiras que se impõem. Como buscamos demonstrar ao longo do capítulo, o podcast é uma linguagem digital emergente que oferece uma série de possibilidades de uso em diferentes níveis da educação, sendo um recurso inclusivo e potencial para o trabalho com a educação básica, seja no modelo presencial ou no remoto. Podcasts permitem ainda a articulação entre diferentes questões que têm mobilizado os debates de educação nos últimos anos, como metodologias ativas e aprendizagem significativa. Eles não são a solução para os desafios da educação, mas podem contribuir com a melhora da aprendizagem. Esperamos que os apontamentos apresentados possam auxiliar na maior presença dos podcasts na educação básica brasileira.

\section{REFERÊNCIAS}

BARROS, G. C.; MENTA, E.. Podcast: produções de áudio para educação de forma crítica, criativa e cidadã. In: Revista de Economía Política de las Tecnologías de la Información y Comunicación, v. 9, n. 1 , abr. 2007.

BÉVORT, E.; BELLONI, M. L.. Mídia educação: conceitos, história e perspectivas. In: Educação \& Sociedade, Campinas, v. 30, n.109, set.-dez. 2009.

BOTTENTUIT JÚNIOR, J. B.; COUTINHO, C. P.. Podcast: uma ferramenta tecnológica para auxílio ao ensino de deficientes visuais. In: VIII LUSOCOM: Comunicação, Espaço Global e Lusofonia. Lisboa: Universidade Lusófona de Humanidades e Tecnologias, 2009, p.2114-2126.

BUCKINGHAM, D.. Cultura digital, Educação midiática e o lugar da escolarização. In: Educação e Realidade, Porto Alegre, v.35, n.3, set.-dez. 2010. 
CASTELLS, M.. A sociedade em rede. São Paulo: Paz e Terra, 2000.

FREIRE, E. P. A.. O podcast como ferramenta de educação inclusiva para deficientes visuais e auditivos. In: Revista Educação Especial, v.24, n.40, maio-ago. 2011.

FREIRE, E. P. A.. Podcast: novas vozes no diálogo educativo. In: Interacções, v. 9, n. 23, 2013.

LÉVY, P.. Cibercultura. São Paulo: Ed. 34, 1999.

LIMA, D. M. X. de; PICANÇO, R. C.. Guia de tecnologias digitais e ensino de História: podcasts de História. 1. ed. Belém: Rfb Editora, 2020.

MORAN, J. M.. A Educação que desejamos. Novos desafios e como chegar lá. 5. ed. São Paulo: Papirus, 2012.

PRENSKY, M.. Digital natives, digital immigrants. In: On the Horizon, MCB Univertiry Press, v.9, n.5, october 2001.

ROCHA, H.. Linguagem e novas linguagens: pesquisa e práticas no ensino de história. In: ROCHA, H.; MAGALHÃES, M.; GONTIJO, R. (Orgs.). O ensino de história em questão. Cultura histórica, usos do passado. Rio de Janeiro: FGV, 2005, p.97-119.

SILVA, M. S.; SILVA, C. A. F. A.. divulgação científica em História por meio de podcasts: possibilidades de educação histórica pela internet. In: LARA, R. M.; CAMARGO, H. W. (Orgs.). Conexões: mídia, cultura e sociedade. Londrina: Syntagma Editores, 2017, p.257-285.

SILVA, M.. Sala de aula interativa: educação, comunicação, mídia clássica. 7. ed. São Paulo: Edições Loyola, 2014.

SOUZA, R. F.. O podcast no ensino de história e as demandas do tempo presente: que possibilidades? In: Transversos: Revista de História, Rio de Janeiro, n. 11, p. 42-62, dez. 2017.

VEEN, W.; VRAKKING, B.. Homo zappiens: educando na era digital. Porto Alegre: Artmed, 2009. 


\section{EDUCAÇÃO ON-LINE E CIBERCULTURA: A APRENDIZAGEM EM REDE}

Edna Marta Oliveira da Silva58

RESUMO: Com o desenvolvimento das sociedades industriais e a necessidade de prover o sistema de produção com indivíduos habilitados, houve a necessidade da criação de espaços educacionais voltados para a formação especializada, o que acabou por dar origem às escolas aos moldes do que conhecemos hoje. Com isso, esses espaços passaram a ser centros de validação e disseminação de um conhecimento fragmentado em disciplinas que passou a compor um currículo estruturado e organizado. Com o advento da cibercultura e as tecnologias digitais de comunicação e informação (TDIC), a disseminação de informações e conhecimento se libertaram dos muros restritos dos espaços educacionais e passaram ser acessadas também em redes no ciberespaço. Sendo assim, o objetivo deste artigo é de apresentar algumas reflexões a respeito da educação on line (EOL) e até que ponto esse novo paradigma da educação a distância (EAD) se apropria das redes formadas no ciberespaço para fomentar a aprendizagem em rede a partir de comunidades de prática. Para tanto, este trabalho tomará como fundamentação teórica os estudos a respeito de aprendizagem em rede e conhecimento conectivo (SIEMENS, 2004; 2005, 2006; DOWNES, 2005; 2012), formação de redes (MARTINO, 2014), cibercultura (LEVY, 1996; 1999), comunidades de prática (LAVE; WENGER, 1991) e educação on line

\footnotetext{
${ }^{58}$ Currículo Lattes: http://lattes.cnpq.br/5742312040887584.
} 
(PIMENTEL; CARVALHO, 2020; SANTOS, 2009; SANTOS; RIBEIRO; CARVALHO, 2019).

Palavras-chave: Cibercultura. Educação on line. Aprendizagem em rede. Formação de redes. Comunidades de prática.

\section{Introdução}

Ao longo da história da humanidade, as sociedades têm procurado formas de transmitir aos seus descendentes todo 0 repositório de seu conhecimento como forma de garantir a sobrevivência dos indivíduos e seus respectivos grupos sociais.

$\mathrm{O}$ ato de aprender é inato a todo ser humano, pois disso depende a nossa sobrevivência. Aprendemos a respirar, a andar, a comer, a falar e, sem esse aprendizado inicial adequado, ou sucumbimos ou vivemos a duras penas. Porém, ao longo do tempo, a disseminação de conhecimento por meio de uma educação formal acabou por se tornar privilégio de certos grupos sociais detentores de algum tipo de poder, tais como o religioso ou o econômico. Nesse sentido, a educação, conforme nos sinaliza Kenski (2007), não pode ser pensada sem levarmos em consideração as relações existentes entre conhecimento, tecnologias e poder, pois a criação de artefatos tecnológicos depende do conhecimento e da aprendizagem dos indivíduos. A autora também entende que a evolução da humanidade pode ser muito bem delineada em certos períodos históricos a partir dos avanços tecnológicos específicos em determinadas épocas.

Tal observação de Kenski (2007), com relação ao paralelo que a autora traça entre a evolução tecnológica e a história da humanidade ressoa, de certa forma, com os estudos de Levy (1999) a respeito do 
advento da internet e da web. De acordo com Levy (1999), há de se ter uma postura aberta para as potencialidades das redes sociais e, ao mesmo tempo, estar consciente de seus problemas, já que nem tudo - que está em rede pode ser considerado bom. Levy também vislumbrava o efeito da eclosão das informações, com o avanço das telecomunicações, como podemos observar em suas palavras:

[...] as telecomunicações geram esse novo dilúvio por conta da natureza exponencial, explosiva e caótica de seu crescimento. A quantidade bruta de dados disponíveis se multiplica e acelera. A densidade dos links entre as informações aumenta vertiginosamente nos bancos de dados, nos hipertextos e nas redes. Os contatos transversais entre os indivíduos proliferam de forma anárquica. É O transbordamento caótico das informações, a inundação de dados, as águas tumultuosas e os turbilhões da comunicação, a cacofonia e o psitacismo ${ }^{59}$ ensurdecedor das mídias, a guerra das imagens, as propagandas e as contrapropagandas, a confusão dos espíritos. (1999, p. 13)

É necessário termos em mente que as observações de Levy (1999) são anteriores à web nos moldes do que temos hoje, com todas a possibilidades de interatividade que nos permitem transitar, selecionar, apagar e alterar informações que podem ser transformadas em conhecimento. Nossa identidade nas redes não se resume mais a de meros consumidores de conteúdo: tornamo-nos também seus produtores (VASINDA; MCLEOD; MORRISON, 2007), graças às tecnologias digitais de informação e comunicação (TDIC). Isso também fez do ciberespaço um ambiente profícuo para a formação de grupos que compartilham informações e conhecimento entre si e com outras redes afins.

O panorama apresentado pode dar uma ideia de como as redes e as TDIC têm impactado nosso modo de viver, incluindo-se também

\footnotetext{
59 Segundo o Dicionário on-line Aulete (2021), "psitacismo", neste contexto apontado pelo autor, quer dizer verborragia, discurso longo e vazio.
} 
a forma como aprendemos e ensinamos. As informações e a disseminação do conhecimento ultrapassaram os muros da escola e estão ao alcance de um simples toque de 'touch screen'. Simples, não? Não, não é. Ao mesmo tempo em que as informações e o conhecimento em rede crescem de forma exponencial, com a mesma facilidade, tornam-se obsoletos em um curto espaço de tempo (GONZALEZ apud SIEMENS, 2004). No "transbordamento caótico de informações", conforme as palavras de Lévy (1999, p. 13), na contemporaneidade, precisamos ter capacidade em reconhecer aquelas informações que são as mais relevantes para nós. A escolha do que aprender e quais os significados atribuídos às informações obtidas perpassam uma realidade em mutação, conforme aponta Siemens (2004).

Tendo em vista essas primeiras considerações, este artigo tem como objetivo refletir sobre a aprendizagem em rede e de que maneira ela pode contribuir para uma educação on-line efetiva, com o auxílio das comunidades de prática e da formação de redes no ciberespaço. Para tanto, serão tomados como base os estudos de Siemens (2004; 2005; 2006) e Downes (2005; 2012), sobre aprendizagem em rede e conhecimento conectivo; de Martino (2014), sobre formação de redes; de Levy (1996; 1999), sobre cibercultura; de Lave e Wenger (1991), sobre comunidades de prática; e de Pimentel e Carvalho (2020), Santos (2009) e Santos, Ribeiro e Carvalho (2019), sobre educação on-line. 60

\footnotetext{
${ }^{60}$ A fundamentação teórica aqui apresentada é parte da dissertação Os games e aprendizagem de língua inglesa sob a ótica do conectivismo, da autora deste artigo.
} 


\section{O 'toma lá, dá cá' nas comunidades virtuais}

Se no início dos tempos a vida em comunidade garantiu aos nossos ancestrais sua sobrevivência e de seus descendentes, hoje, as comunidades do século XXI têm outros formatos, a ponto de não estarem mais restritas às questões de espaço e tempo, pois agora também podem ser virtuais, como aponta Martino (2014). Para este autor, o termo 'virtual' tem o mesmo sentido atribuído por Lévy (1996, p. 17-18), para quem "a virtualização não é uma desrealização (a transformação de uma realidade num conjunto de possíveis), mas uma mutação de identidade, um deslocamento do centro da gravidade do objeto ontológico considerado", já que uma das principais características da virtualização é o "desprendimento do aqui e agora" (LÉVY, 1996, p. 19). Para Lévy (1996), a virtualização acontece quando uma entidade - seja ela um indivíduo, um grupo de pessoas, uma informação - torna-se 'não presente' ou desterritorializada. Há, portanto, o desligamento da entidade em relação ao espaço físico, assim como da sua relação com o tempo. Com isso,

[...] a virtualização submete a narrativa clássica a uma prova rude: unidade de tempo sem unidade de lugar, [...] continuidade de ação apesar de uma ação descontínua. [...] A sincronização substitui a unidade de lugar, e a interconexão, a unidade de tempo (LÉVY, 1996, p. 21).

Com suas percepções a respeito da virtualização, Lévy (1996) resgata, de certa forma, a característica nômade dos homens préhistóricos e traça um paralelo dessa nova configuração com a das comunidades virtuais, na forma como o meio virtual favorece o surgimento de "interações sociais onde as relações se reconfiguram com um mínimo de inércia" (LÉVY, 1996, p. 21). As comunidades virtuais têm favorecido o encontro de interlocutores que, muito provavelmente, não teriam a chance de se conhecer presencialmente. 
Isso remete às ideias de Rheingold (1997 apud Martino, 2014, p. 4445), quando o autor compara as comunidades virtuais a "teias de relações pessoais", pois são compostas por entidades diversas que têm assuntos em comum e que mantêm certas relações por um tempo razoavelmente longo. A articulação dessas relações entre indivíduos acaba por formar estruturas, redes de fatos encadeados. No entanto, devemos ter mente que a manutenção dessas teias só será possível enquanto os indivíduos (ou as entidades) que a compõem tiverem não somente objetivos em comum, mas também enquanto contribuírem com novos inputs relevantes. Para Martino,

[...] o interesse em um assunto ou um determinado tema é em geral um dos primeiros fatores responsáveis por levar uma pessoa a fazer parte de um agrupamento; no entanto, dentro de uma comunidade virtual, o grau de participação e engajamento de um indivíduo tem como base o que poderia ser entendido como uma economia baseada na troca - no caso, de informações. (2014, p. 46-47)

A troca de informações e de interesses são princípios básicos para que as interações em uma comunidade virtual ocorram. "Cada pessoa deve estar disposta a compartilhar com outras as informações que tem, esperando que, quando precisar, igualmente deve encontrar indivíduos com as informações de que precisa" (MARTINO, 2014, p. 47). Tal constatação leva o autor a acreditar que, em uma comunidade virtual, é praticamente uma questão ética a reciprocidade entre os membros que a compõem. Além disso, a quantidade de fluxo das informações compartilhadas que permeia uma comunidade favorece a criação de espaços para debates e até mesmo de tomada de decisões que podem influenciar, inclusive, o mundo concreto (MARTINO, 2014). $E$, nesse sentido, podemos entender tais espaços de troca como contextos de aprendizagem a respeito de determinados assuntos de 
interesse compartilhado, ou seja, é um ambiente que favorece à aprendizagem situada.

A aprendizagem situada é uma descrição teórica da aprendizagem ligada ao contexto, com ênfase "na atividade no mundo e com o mundo, na visão em que o agente, a atividade e o mundo constituem-se mutuamente" 61 (LAVE; WENGER, 1991, p. 33, tradução minha) em grupos constituídos por comunidades de prática, nas quais seus membros trabalham em prol de um objetivo em comum. Para os autores, é na comunidade de prática que ocorrem, ao mesmo tempo, a aprendizagem e a aplicação daquilo que se aprende. Os indivíduos não somente compartilham um mesmo objetivo, mas também orientam e dão suporte para aqueles recém-chegados à comunidade. Há, portanto, uma distinção dentro da comunidade de prática entre mestres e novatos, sendo que estes últimos ocupam um papel periférico dentro da comunidade até que se tornem tão hábeis quanto os membros mais antigos. Esse é o processo que Lave e Wenger chamam de 'participação periférica legitimada' (doravante, PPL) e

[...] diz respeito ao processo pelo qual os recém-chegados se tornam parte da comunidade. As intenções para aprender de um indivíduo são engajadas e o significado da aprendizagem é configurada por meio do processo de se tornar um participante pleno em uma prática sociocultural. Este processo social não somente inclui, mas de fato engloba, a aprendizagem de habilidades especializadas. ${ }^{62}$ (1991, p. 29, tradução minha)

\footnotetext{
${ }^{61}$ No original: "[...] on activity in and with the world; and on the view that agent, activity, and the world mutually constitute each other" (LAVE; WENGER, 1991, p. 33) Inserir a referência aqui também. Repetir isso para todas as citações em língua estrangeira.

62 No original: "It concerns the process by which newcomers become part of a community of practice. A person's intentions to learn are engaged and the meaning of learning is configured through the process of becoming a full participant in a sociocultural practice. This social process includes, indeed it subsumes, the learning of knowledgeable skills" (LAVE; WENGER, 1991, p. 29) Inserir a referência aqui também.
} 
Podemos observar no conceito de PPL o alto grau de socialização atribuído a essa forma de aprender. Uma comunidade de prática constitui a sua identidade como tal porque há um interesse em comum entre seus participantes, o que confere a cada um deles o sentimento de pertencimento àquela comunidade. Além disso, o domínio de uma área do conhecimento fornece as bases de uma comunidade de prática e reafirma seus objetivos.

A partir dos conceitos apresentados em relação à aprendizagem propiciada pela formação de comunidades de prática, o próximo passo será entender como, a partir dessas comunidades, podem ser formadas redes para o compartilhamento de informações e formação de conhecimento.

\section{A formação de uma rede: laços fortes ou fracos?}

Para compreendermos o funcionamento de uma rede, a primeira coisa a fazer é entendermos como suas conexões são mantidas para que as informações possam ser distribuídas. Martino (2014, p. 68) cita o trabalho de Granovetter (1973) para exemplificar a formação das conexões (laços) em uma rede, comparando-a a partir do nível de relacionamento entre as pessoas. Podemos ter 'conhecidos', 'amigos' e 'melhores amigos', mas o número de 'conhecidos' será maior do que dos 'amigos' e estes, maior do que dos 'melhores amigos'. Ao classificarmos os indivíduos dessa forma, percebemos que podem existir tanto os laços sociais mais fortes ('melhores amigos') quanto mais fracos ('conhecidos'). 
Quando pensamos em laços 'fortes', no entanto, existe uma tendência em associar essa característica à ideia de proximidade ${ }^{63}$ entre os indivíduos e, num primeiro momento, poderíamos acreditar que seriam exatamente esses laços os principais responsáveis pelo funcionamento de uma rede. A verdade, no entanto, é que a manutenção de uma rede depende também dos seus laços 'fracos'. E como isso é possível? Isso acontece porque existe uma relação de dependência entre a quantidade de indivíduos e o fluxo da informação, ou seja, é por meio da rede dos 'conhecidos' que se aumenta "a amplitude de divulgação de dados existentes nesse tipo de contato [...]. Justamente por não serem ligações diretas, a chance de se espalharem em várias direções e, portanto, de criarem caminhos para a conexão entre pessoas, é maior" (MARTINO, 2014, p. 69).

A constituição de uma rede também pressupõe a existência de nós e de conexões. Os nós podem ser quaisquer elementos passíveis de conexões com outros elementos. Para que ocorra uma conexão, basta que qualquer nó se ligue a outro (SIEMENS, 2005) e, uma vez que a rede se estabeleça, o fluxo de informações pode ir de um domínio a outro com relativa facilidade. Tanto Siemens (2005) quanto Martino (2014) reconhecem a importância das conexões em uma rede de aprendizagem e, mesmo quando nem todas as conexões têm o mesmo peso, elas ainda influenciam a estrutura da rede.

Para Siemens (2005), há uma série de fatores que favorecem o fortalecimento das conexões, tais como: motivação, emoções, exposição, padronização, lógica e experiência. A motivação influencia nossa receptividade a determinados conceitos e o desejo de aprofundar as conexões da rede; as emoções contribuem no sentido de como nos sentimos ou valorizamos, ao mesmo tempo em que permitimos outros

\footnotetext{
${ }^{63}$ A ideia de estar próximo, neste contexto, não se refere exclusivamente ao espaço físico, mas também ao nível de intimidade entre os indivíduos.
} 
pontos de vista; exposição refere-se ao crescimento de um nó em termos de popularidade (o quanto ele se torna relevante em uma rede) a ponto de influenciar todo o processo de pensamento; a padronização, um dos elementos de aprendizagem mais significativos, consiste em reconhecer a natureza e a organização de vários tipos de informação que podem gerar conhecimento; a lógica, considerada um marco do processo de aprendizagem, fornece os nós para formar as conexões, pois redes de aprendizagem são formadas e estruturadas a partir do processo de pensar, uma vez que é condição necessária para avaliar e reconhecer padrões entre diferentes conceitos e elementos da rede; e, por último, a experiência, pois as conexões só se formam a partir do momento que um indivíduo está ativo dentro de seu campo de atuação.

Mas como reconhecer se uma rede é aquela que tem a melhor qualidade de informações? Siemens (2006) aponta para a confiabilidade de uma rede quando se pode encontrar nela pontos de vistas de especialistas, ou seja, pessoas que têm tanto conhecimento teórico quanto vivência em uma área específica. O autor cita, como exemplo, os sistemas de recompensa em muitas comunidades on-line, pois eles validam os indivíduos com base no seu histórico dentro de um espaço específico.

A confiabilidade de uma rede reside na "moral implícita da comunidade virtual [...], a reciprocidade" (LÉVY, 1999, p. 128), ou seja, se aprendemos por meio da rede, devemos também contribuir com nosso conhecimento e/ou informações quando assim for solicitado. E o que ganhamos com isso? Para Lévy (1999, p. 128), o ganho surge como "a recompensa (simbólica) [...] da reputação de competência que é constituída a longo prazo na 'opinião pública' da comunidade virtual", já que essas redes individuais se conectam a outras e acabam por formar novos espaços de conhecimento. 
Ao compartilharmos em rede, na verdade, estamos classificando e filtrando aquilo que consideramos relevante. Siemens (2006) afirma que em termos conceituais, apesar da democracia inerente a esses novos espaços, todos estão em busca da mesma clareza e coerência que desejamos encontrar em outras fontes de conhecimento. Mesmo que não haja um controle centralizado, criam-se diretivas por meio do diálogo e da transparência para a validação do conhecimento. Com isso, segundo Siemens, "precisamos confiar na formação das redes e no desenvolvimento de ecologias do conhecimento. Precisamos nos tornar pessoas diferentes com hábitos diferentes" (2006, p. 23, tradução minha) ${ }^{64}$. As questões aqui apresentadas tornam-se a base para que possa haver a aprendizagem em uma rede.

\section{Aprendizagem em rede}

O mundo em que vivemos tem uma relação diferente com o conhecimento, se comparado ao que tínhamos em séculos anteriores. O conhecimento, atualmente, se tornou tão importante para a sociedade contemporânea quanto era a terra no sistema feudal e o capital, na sociedade industrial (BROCKMAN, 2002). De acordo com Siemens (2006), o conhecimento que antes servia a fins econômicos, para criação, produção e comercialização, hoje é a economia em si.

De fato, com o advento da Web 2.0, temos tido ao nosso dispor ferramentas de simples manuseio, mas que proporcionam muita interatividade entre seus usuários, permitindo conectar informações com a mesma velocidade que podem fornecer feedback à sua fonte original. Com isso, a Web 2.0 trouxe mudanças significativas na forma

\footnotetext{
64 No original: "we must rely on net-work formation and development of knowledge ecologies. We must become different people with different habits" (SIEMENS, 2006, p. 23)
} 
como consumimos mídia, autenticamos e validamos o conhecimento, dado o seu alto nível de dialogicidade entre indivíduos.

Tradicionalmente, o conhecimento tem sido descrito de diversas formas, mas duas têm sido consideradas como as mais importantes: o conhecimento qualitativo, com suas raízes na antiguidade grega, e o quantitativo, com os árabes e, mais tarde, incorporado na filosofia renascentista (DOWNES, 2012). Entretanto, tanto Siemens como Downes acreditam que se faz necessário pensar em um tipo de conhecimento que dê conta desse novo contexto que surgiu a partir da Web 2.0, uma vez que o saber e o aprender podem ser definidos, na atualidade, pelas conexões que são feitas. Siemens (2006) e Downes (2012) concordam que é preciso considerar a necessidade de um novo fundamento epistemológico para o conhecimento e o aprendizado que acontecem em rede. A partir dessa perspectiva, Downes (2012) propõe considerar o conhecimento como distribuído, o que ele chama de conhecimento conectivo, uma vez que é difundido por diversas entidades. Neste tipo de conhecimento, mais importante que a mera relação de existência entre entidades é a interação que ocorre entre elas.

Downes (2005) ressalva que não é qualquer rede que pode ser capaz de elaborar o conhecimento conectivo e são necessárias certas características em uma rede para que ela se torne um terreno fértil para o surgimento desse tipo de conhecimento. São elas:

1. Diversidade: é necessário haver um amplo número de diferentes pontos de vista. Só há geração de um novo conhecimento em uma rede se seus membros são diversos e se realizam coisas distintas. Se todos fazem as mesmas coisas, 
nada de novo é gerado em suas interações e, consequentemente, não há um novo conhecimento;

2. Autonomia: há de se verificar se cada indivíduo contribui com seus valores, decisões e conhecimento ou se agem sem refletir, sem usar a razão, sob a orientação ou mando de terceiros. Ser autônomo em uma rede significa tomar suas próprias decisões em relação aos seus objetivos e metas. Não há um gerenciamento centralizador; cada membro tem sua própria agência dentro da rede;

3. Interatividade: o conhecimento deve ser oriundo da produção de uma interação entre indivíduos, e não somente uma coletânea de diferentes pontos de vista. Se uma rede apresenta uma dinâmica conectivista, o conhecimento não é simplesmente passado de um membro para outro, mas sim oriundo de um comportamento comunicativo da rede como um todo. Portanto, o conhecimento não pertence a uma só pessoa e terá um nível de complexidade a ponto de refletir uma resposta comunitária a um fenômeno complexo;

4. Abertura: a rede deve permitir a entrada de outros pontos de vista no sistema. Isso quer dizer que os membros que a compõem podem juntar-se ou sair da rede com facilidade, assim como participar livremente das atividades ali desenvolvidas. Com isso, a distinção entre membros e não membros cai por terra, pois há uma diversidade de diferentes participações, seja na interação ativa com um grupo ou numa simples participação oculta e/ou ocasional. A abertura da rede permite um bom fluxo da informação que irá gerar um novo conhecimento, ao contrário de uma rede fechada.

Ao pontuar essas características, Downes (2012) admite que a proposta de um terceiro conhecimento - o conectivo - não faz dele, 
necessariamente, mais confiável do que os tradicionais. Longe de apontar o conhecimento conectivo como "uma pílula mágica" (DOWNES, 2005, on-line), a proposta é a de fornecer novas bases que possam dar conta do conhecimento distribuído, pois o contexto no qual o conhecimento agora ocorre, assim como seu fluxo e características, são diferentes daqueles que havia no passado.

As propostas de Downes (2012) coadunam com as ideias de Siemens (2006) na comparação que este autor apresenta entre a organização do conhecimento tradicional - que Siemens (2006) descreve como hierarquizado, estático e compartimentado - e a organização do conhecimento em rede, muito mais dinâmico, e que consiste de ecologias, ou seja, de modelos que se adaptam e reajustam às mudanças que permeiam uma rede. É a partir da integração das estruturas da rede e da qualidade das conexões que será determinada a qualidade do conhecimento compartilhado. A questão é, portanto, como formar redes confiáveis que realmente sejam eficazes não somente na disseminação, mas também na validação do conhecimento. Redes apresentam diversidades de pontos de vista e cada um dos nós que as compõem corresponde a um indivíduo com a capacidade de formar seus próprios espaços e redes de notícias.

A quantidade de informações, portanto, pode ser um fator complicador em uma rede, pois precisamos filtrar aquilo que chega até nós. Se há um número exponencial de informações ao nosso dispor, pode-se questionar até que ponto somos realmente produtores de conhecimento em rede ou se somos, na verdade, meros selecionadores de conteúdo. Esse é um questionamento do próprio Siemens (2006), que admite que talvez seja esse o 'pensar' da era digital: "Nós não vivemos nossas vidas em cognição ativa. Gastamos muito tempo em compartimentos que criamos. Ao invés de pensar, estamos somente 
classificando e filtrando"65 (SIEMENS, 2006, p. 23, tradução minha). A constatação desse autor o leva a concluir que se faz necessário confiar não somente na formação das redes, mas também no desenvolvimento de novas ecologias do conhecimento. "Precisamos nos tornar pessoas diferentes com hábitos diferentes"66 (SIEMENS, 2006, p. 23), pois conhecer, nos dias de hoje, não é mais somente um processo cognitivo: é também saber reconhecer padrões.

Com base nas questões em relação ao conhecimento na era digital, torna-se necessária uma revisão daquelas relacionadas à aprendizagem que emerge desse contexto, uma vez que "aprendizagem é parceira do conhecimento"67 (SIEMENS, 2006, p. 26). As redes, dadas as suas especificidades, favorecem ao aprendizado contínuo, e este, ainda que não exclusivamente, é facilitado pela tecnologia digital, já que ela nos permite conectarmo-nos uns aos outros de modo a criar a nossa própria rede de aprendizagem. Siemens (2006) afirma que a aprendizagem vai além da aquisição do conhecimento, pois até conhecermos algo, passamos por etapas que antecedem a própria experiência da aprendizagem: exploramos, perguntamos, decidimos e selecionamos para darmos conta de solucionar um problema. E só sabemos se a experiência de aprendizado é realmente válida se, ao longo do processo, avaliamos adequadamente cada uma das etapas, com os instrumentos apropriados a cada uma delas.

Em suma, "aprender é formar redes: adicionar novos nós, criar novos caminhos neurais" 68 (SIEMENS, 2006, p. 29). Com isso, Siemens nos mostra que, apesar de o indivíduo ser capaz de selecionar redes para a formação de seu conhecimento, tanto o aprendizado

\footnotetext{
65 No original: "We do not live our lives in active cognition. We spend much of our time in containers that we have created. Instead of thinking, we are merely sorting and filtering" (SIEMENS, 2006, p. 23)

${ }^{66}$ No original: "We must become different people with different habits."

67 No original: "Learning is a peer to knowledge."

68 No original: "Learning is network formation: adding new nodes, creating new neural paths".
} 
quanto o próprio conhecimento são processos que não estão totalmente sob controle, pois podem residir fora de nós. Aprendemos a partir das mais diferentes fontes, seja em uma organização ou em um banco de dados. Nesse sentido, a fluidez do conhecimento e o compartilhamento de informações, potencializados pelas TDIC, podem favorecer a aprendizagem, uma vez que "as conexões que nos permitem aprender mais são mais importantes do que o nosso estado atual de conhecimento"69 (SIEMENS, 2006, p. 30).

Na era digital, e com a expansão rizomática das informações disseminadas por meio das TDIC, 'saber onde' achar uma informação e 'saber com quem', ou seja, a fonte, é mais importante do que saber 'o quê' ou 'como', de acordo com Siemens (2006). Esse fluxo demanda um modelo de rede de aprendizagem que permita descarregar parte do processamento e da interpretação das informações. Para Siemens (2006), o ato de conhecer ou de saber algo é descarregado nas e das redes $^{70}$, formadas por indivíduos que usam de sua agência para criar seus próprios espaços de aprendizagem, por meio de redes de notícias, de informações, filtrando e disseminando, ao mesmo tempo, o conhecimento. Com o intuito de explicar os movimentos que ocorrem dentro de uma rede e que contribuem para a disseminação de conhecimento, Siemens, aplica o conceito de ecologia, oriundo da biologia, pois estamos lidando com "um sistema aberto, dinâmico, interdependente, diverso, parcialmente auto-organizado, adaptativo e frágil" (2006, p. 90) 71 . Assim, podemos entender que existe dentro de

\footnotetext{
69 No original: "The connections that enable us to learn more are more important than our current state of knowledge."

${ }^{70}$ A afirmação de Siemens (2006) de que o conhecimento da era digital é "descarregado em artefatos não humanos" é a que mais tem recebido críticas no conectivismo. Para Siemens, (2006) aceitar ou não essa preposição depende de como entendemos o conceito de conhecimento. De acordo com 0 autor, 0 conhecimento pode ser percebido de duas formas: a) como algo que descreve algum aspecto do mundo; b) como algo sobre o qual podemos agir. Nesse sentido, para Siemens (2006), tais assertivas, por si só, já justificariam "uma visão de conhecimento possível de residir em artefatos não humanos" (SIEMENS, 2006, p. 150).

71 No original: "an ecology as an open system, dynamic and interdependent, diverse, partially selforganizing, adaptive, and fragile."
} 
uma rede uma 'ecologia da aprendizagem', que, para Siemens (2006, p. 87-88), deve apresentar as seguintes características:

1. Deve ser informal e não estruturada. Não é o sistema que irá definir o aprendizado. É necessário que o sistema seja flexível o suficiente para que seja moldado pelos próprios indivíduos e de acordo com as suas necessidades;

2. Deve proporcionar ferramentas e as mais diversas oportunidades, não somente para conectar os indivíduos, mas também que proporcionem o diálogo entre eles;

3. É comum, em um início de um projeto, de uma nova comunidade, os indivíduos estarem altamente motivados. Entretanto, também é muito comum que, com o tempo, isso vá diminuindo. Para Siemens (2006), a criação de uma ecologia de conhecimento compartilhado depende de os indivíduos perceberem a evolução constante em um ambiente;

4. Seja presencialmente ou on-line, os indivíduos devem se sentir seguros e confortáveis nas relações sociais promovidas pelo ambiente. A confiança é essencial;

5. O ambiente precisa ser simples. Para Siemens (2006), é justamente o alto nível da complexidade que leva, por vezes, ao fracasso das grandes ideias. A simplicidade torna o ambiente da ecologia de aprendizagem mais efetivo e deve refletir tanto nas ferramentas selecionadas quanto na própria criação da estrutura da comunidade;

6. As palavras de ordem devem ser: descentralização, motivação e conectividade, em oposição à centralização, ao controle e ao isolamento; 
7. Experimentação e fracasso fazem parte de uma ecologia de aprendizagem e, portanto, deve haver uma tolerância alta em relação a isso.

Um ambiente de aprendizagem que apresente a ecologia proposta por Siemens (2006) irá sofrer as influências dos indivíduos que dela participam. $O$ indivíduo muda, age, e o ambiente responde às interferências. "Ao adicionarmos dimensões sociais à nossa cognição, criamos um modelo adaptativo que aprende baseado nas atividades de todos os membros naquele espaço"72 (SIEMENS, 2006, p. 44). Se pensarmos em um indivíduo como um elemento de conexão em uma rede, a sua interferência, e consequente adaptação da rede, irá também mudar os conteúdos ali disponibilizados. São as diferentes perspectivas quer irão dar significado à rede, a partir da força combinada dos indivíduos. Tendo em mente os conceitos apresentados até o momento, há de se pensar até que ponto a educação a distância $(\mathrm{EaD})$ tem se apropriado desses elementos para tornar a aprendizagem mais conectada, inclusiva e colaborativa. A cibercultura permitiu a ampliação da forma como nos comunicamos e interagimos e cabe agora refletirmos sobre como isso se dá dentro do âmbito educacional. A aprendizagem em rede depende de conexões de nós que possibilitem - fluir das informações, as quais favorecem a formação de conhecimento. Em função disso, estamos vivendo um limiar, dentro da $\mathrm{EaD}$, da quebra de paradigmas que estejam em consonância com a cibercultura, cuja característica principal é da "conexão generalizada em rede [que] potencializa a emergência de grupos e de comunidades on-line $[\ldots] "$ " (PIMENTEL; CARVALHO, 2020b, on-line). Feitas as considerações anteriores a respeito de formação de redes e da

\footnotetext{
72 No original: "As we add social dimensions to our cognition, we can create an adaptive model that learns based on the activities of all members in a space."
} 
aprendizagem que delas emergem, associada ao conceito de comunidades de prática, podemos agora refletir sobre como esses conceitos se dão na educação on-line (EOL).

\section{Da educação a distância para a educação on-line}

Antes de adentrarmos propriamente na EOL, devemos abrir um parêntese com relação ao conceito dessa modalidade de ensino em contrapartida com a EaD e, para tanto, serão levados em consideração os estudos de Pimentel e Carvalho (2020a) sobre esse tema. Os autores entendem a EaD como uma opção de modalidade de ensino em contraponto à educação presencial e apontam algumas características recorrentes nela. Dentre elas, destaca-se o fato de a EaD fazer uso de redes de computadores para a difusão e apresentação de conteúdos pré-estabelecidos e restritos a um ambiente virtual de aprendizagem (AVA). Nesse contexto, há uma tendência ao isolamento dos alunos, pois privilegia-se a autoaprendizagem e o autoestudo. Além disso, a comunicação entre os atores envolvidos é predominantemente unidirecional, o que, segundo os autores, configura-se em uma tendência a uma abordagem de ensino de cunho instrucionista e massiva.

Os apontamentos feitos por Pimentel e Carvalho (2020b), no entanto, não têm como objetivo conferir qualquer tipo de desmerecimento à $\mathrm{EaD}$ em relação à $E O L$, já que esta última "não separa práticas da educação presencial das práticas da educação a distância, uma vez que [...] estar geograficamente disperso não é estar distante, principalmente quando temos tecnologias digitais em rede" (SANTOS, RIBEIRO, CARVALHO, 2019, on-line). A distinção entre EaD e EOL, porém, é necessária, já que, como apontam Santos, Ribeiro e Carvalho: 
Por exigir metodologia própria, a EOL requer um desenho didático hipertextual, podendo ser composto por diversos formatos de conteúdos, lançando mão de muita conversação e autoria, conectado com redes sociais, não existindo um padrão definido e único, devendo ser concebido de acordo com o contexto no qual a formação está situada e a formação a que se objetiva. (2019, online)

A EOL congrega, em sua essência, o melhor dos dois mundos, da EaD e da cibercultura, pois as novas interfaces de um AVA propiciam não somente a interatividade, como também a aprendizagem de forma mais colaborativa e multidirecional. Especificamente sobre a cibercultura, Pimentel e Carvalho apontam que

[...] vivemos, hoje, em um (ciber)espaço-tempo propício à aprendizagem em rede: conectar-se, conversar, postar, curtir, comentar, compartilhar, colaborar, tornar-se autor, expor-se, negociar sentidos, co-criar ... que outras palavras lhe vêm à mente quando falamos de valores e práticas que caracterizam a nossa (ciber)cultura contemporânea. (2020a, on-line)

E como podemos conciliar a EaD e a cibercultura de modo a termos a EOL? As pesquisas de Pimentel e Carvalho (2020a, on-line) nos apontam para oito princípios da EOL, os quais sinalizam "a possibilidade de outras práticas didático-pedagógicas para a modalidade a distância", quais sejam:

1. Conhecimento não deve ser ", entregue ao aluno sob a forma de conteúdos fechados, mas que os convidem à participação em cocriação e como coautores; 
2. Curadoria de conteúdos, com sínteses e roteiros de estudo, e não de materiais produzidos para conteúdos específicos para EaD. Nesse caso, o professor faz a curadoria e a seleção de conteúdos mais relevantes para um determinado tema. Tais conteúdos podem ser mapeados e resultarem em roteiro de estudos, pois, já que o conhecimento é entendido como "obra aberta", os alunos também contribuem com a produção de conteúdos;

3. Ambiências computacionais diversas. Aqui, trata-se do uso de outros sistemas computacionais que sejam interativos e on-line, tais como o uso redes sociais. Já que estamos tratando dos recursos do ciberespaço, não se pode mais ficar limitado à exclusividade do uso de um AVA;

4. A aprendizagem deve ser em rede e não isolada. Este princípio, longe de se tratar de alunos discutindo algum conteúdo, toma como base a construção de conhecimento de forma colaborativa, mediada pelo professor, ou seja, cada indivíduo contribui com suas descobertas. Nesse caso, a rede de computadores tem um papel fundamental no sentido de promover uma real interação social entre todos os envolvidos;

5. Conversação entre todos, em interatividade. Em outras palavras, não existe um 'apresentador de conteúdos', o que, na maioria das vezes, acaba sendo o papel desempenhado pelo professor. Ao professor, cabe planejar uma "situação conversacional e sua realização por meio de uma ambiência computacional, lançando mão de serviços variados de conversação pela internet" (PIMENTEL; CARVALHO (2020a, on-line);

6. Atividades autorais inspiradas nas práticas de cibercultura. A diferença dessas atividades, se comparadas às da aprendizagem bancária, demandam o 'aprender fazendo', ou seja, o aluno é solicitado a colocar em prática algum conhecimento adquirido, de modo a ressignificá-lo; 
7. Mediação docente online para colaboração. Isso demanda do professor uma mediação ativa, na qual o docente assume como função de promotor da colaboração entre os alunos. Nesse contexto, no qual os conflitos e as divergências se tornam mais evidentes, as emoções que surgem podem propiciar mudanças no convívio social, com consequência no processo formativo dos alunos;

8. Avaliação formativa e colaborativa, baseada em competências. Ao contrário dos exames presenciais, esse tipo de avaliação contempla tanto o grau de conhecimento adquirido como também o das habilidades desenvolvidas para colocar em prática um determinado conhecimento. Além disso, são também levadas em consideração as atitudes dos alunos, com relação ao seu engajamento, participação e colaboração nas atividades propostas. Tal avaliação não parte somente do professor, mas é também considerada uma ação coletiva na qual todos refletem sobre suas trajetórias de aprendizagem.

Os princípios apontados por Pimentel e Carvalho (2020a) nos mostram que a EOL tem suas bases fundamentadas no uso de artefatos digitais e interfaces comunicacionais que propiciam a interatividade, a colaboração, a formação de redes de aprendizagem e de compartilhamento de informações e de conhecimento. Longe de ser uma pedagogia meramente conteudista e bancária, a EOL demanda participação ativa de todos os seus atores, o que ressoa profundamente com o contexto da cibercultura.

\section{Conclusão}

Não podemos negar que, ainda hoje, a EaD sofre preconceitos por ser considerada uma modalidade de ensino de menor qualidade, 
se comparada ao ensino presencial. Apesar disso, não se pode negar a sua expansão expressiva nos últimos anos, motivada, entre outras coisas, pelo desenvolvimento tecnológico. As TDIC, sem sombra de dúvidas, permitiram tanto aos educandos quanto aos gestores, professores e tutores, um contato mais próximo e profícuo, propiciando assim os processos de ensino e aprendizagem.

A EaD, no entanto, se encontra em nosso movimento de mudança, rumo à EOL. Como abordado neste trabalho, não se trata de abandonar tudo o que temos aprendido com a EaD, mas de revermos o que temos feito até este momento. Os pontos trazidos à luz da discussão ao longo deste artigo - a aprendizagem em rede, o processo de formação de redes e de comunidades de prática - podem ser cruciais para refletirmos sobre os rumos da $\mathrm{EaD}$ em seu processo de se tornar uma EOL de fato, especialmente por estarmos tratando da educação no ciberespaço, locus de manifestação da cibercultura. E, se a cibercultura é um fenômeno que permeia toda a nossa sociedade e, como "a rede é a palavra de ordem do ciberespaço" (SANTOS, 2009, p. 5661), há de ser levada em consideração suas contribuições e impactos no âmbito educacional.

Porém, não devemos nos esquecer de uma questão fundamental, qualquer que seja a modalidade de ensino utilizada, presencial, EaD ou EOL. Antes de tudo, ela deve, obrigatoriamente, ser de qualidade. O uso das TDIC e do ciberespaço com objetivos educacionais somente se justifica se, de alguma forma, elas contribuírem para a aprendizagem e a formação de conhecimento. Portanto, deve-se ter mente, inicialmente, o objetivo a ser cumprido ao adotarmos as TDIC como mediadoras das práticas pedagógicas e sua real contribuição para a educação. 


\section{REFERÊNCIAS}

AULETE ON-LINE. Psitacismo 2021. Disponível em: <http://www.aulete.com.br/psitacismo>. Acesso em: 07 fev. 2021.

BROCKMAN, J.. The next fifty years: science in the first half of the twenty-first century. New York: Vintage, 2002.

DOWNES, $\quad$ S.. $\quad$ E-learning 2.0. 2005. Disponível em: < http://elearnmag.acm.org/featured.cfm?aid=1104968>. Acesso em: 07 fev. 2021.

DOWNES, S.. An introduction to Connective Knowledge. In: Connectivism and Connective Knowledge: Essays on meaning and learning networks. 2012. Disponível em: <https://www.downes.ca/files/books/Connective_Knowledge-19May2012.pdf>. Acesso em: 07 fev.2021. KENSKI, V. M.. Educação e Tecnologias: o novo ritmo da informação. Campinas: Papirus, 2007. (Coleção Papirus Educação).

LAVE, J.; WENGER, E.. Situated Learning: Legitimate Peripheral Participation. Cambridge: Cambridge University Press, 1991.

LÉVY, P.. O que é o virtual? Trad. Paulo Neves. São Paulo: Editora 34, 1996. (Coleção TRANS).

LÉVY, P.. Cibercultura. Trad. Carlos Irineu Costa. São Paulo: Editora 34, 1999.

MARTINO, L.. M. S.. Teoria das mídias digitais: linguagens, ambientes, redes. Petrópolis: Vozes, 2014. PIMENTEL, M.; CARVALHO, F. da S. P.. Princípios da Educação Online: para sua aula não ficar massiva nem maçante! In: SBC Horizontes, maio 2020a. ISSN 2175-9235. Disponível em: <http://horizontes.sbc.org.br/index.php/2020/05/23/principios-educacao-online>. Acesso em: 14 fev. 2021.

PIMENTEL, M.; CARVALHO, F. da S. P.. Aprendizagem online é em rede, colaborativa: para o aluno não ficar estudando sozinho a distância. In: SBC Horizontes, jun. 2020b. ISSN 2175-9235. Disponível em: <http://horizontes.sbc.org.br/index.php/2020/06/02/aprendizagem-em-rede>. Acesso em: 14 fev. 2021. SANTOS, E.. Educação online para além da EAD: um fenômeno da cibercultura. In: Anais do Congresso Internacional Galego-Português de Psicopedagogia. Universidade do Minho, Braga, Portugal, 2009, p. 5658-5671. Disponível em <https://www.educacion.udc.es/grupos/gipdae/documentos/congreso/xcongreso/pdfs/t12/t12c427.pdf >. Acesso em: 14 fev. 2021.

SANTOS, R.; RIBEIRO, M. R.F., CARVALHO, F.. S.P. Educação Online: aprenderensinar em rede. In: SANTOS, E, O.; SAMPAIO, F. F.; PIMENTEL, M. (Org.). Informática na Educação: fundamentos e práticas. Porto Alegre: Sociedade Brasileira de Computação, 2019. (Série Informática na Educação CEIESBC, v.1) Disponível em: <https://ieducacao.ceie-br.org///educacaoonline/>. Acesso em: 14 fev. 2021. SIEMENS, G.. Connectivism: a learning theory for the digital age. 2004. Disponível em: <https://jotamac.typepad.com/jotamacs_weblog/files/Connectivism.pdf>. Acesso em: 07 fev. 2021. SIEMENS, G.. Connectivism: learning as network-creation. 2005. Disponível em: <http://www.elearnspace.org/Articles/networks.htm>. Acesso em: 18 jan. 2015.

SIEMENS, G.. Knowing Knowledge. $2006 . \quad$ Disponível em: <hhttps://amysmooc.files.wordpress.com/2013/01/knowingknowledge_lowres-1.pdf f>. Acesso em: 07 fev. 2021.

VASINDA, S.; MCLEOD, J.; MORRISON, J.. 1+1=3: Combining language experience approach with Web 2.0 tools. LEA SIG (of the International Reading Association) newsletter, 381(1), p. 6-10. 2007. Disponível em: <http://juliemcleod.org/portfolio/pdfs/1+1=3.pdf>. Acesso em: 07 fev. 2021. 


\title{
A PARTICULARIDADE DA DEMOCRACIA NA REVOLUÇÃO BURGUESA NO BRASIL
}

\author{
Eduardo Santana Valli ${ }^{73}$ \\ Verônica Nogueira Ângelo ${ }^{74}$
}

Resumo: $O$ presente trabalho tem como objeto de estudo o conceito de democracia a partir das proposições teóricas elaboradas por Florestan Fernandes. As discussões sobre a questão democrática se inserem na elaboração de uma tese, na qual o autor se debruça sobre - cenário brasileiro desmistificando a concepção de subdesenvolvimento, abarcando as composições da sociedade de classes e Estado. Pauta-se, então, o seguinte elemento problematizador: qual a concepção de democracia para Florestan Fernandes na obra Revolução Burguesa no Brasil: ensaio de interpretação sociológica (1976)? Para compor um caminho que contemple uma resposta ao problema proposto, foram elencados dois objetivos específicos, sendo que o primeiro se concentra em identificar o conceito de democracia em Florestan Fernandes na obra Revolução Burguesa no Brasil: ensaio de interpretação sociológica e o segundo em relacionar a categoria de democracia restrita à apreensão da particularidade brasileira. Ao final dessa investigação, foi possível constatar que a democracia brasileira é essencialmente restrita sob a leitura sociológica de Florestan Fernandes, na qual essa categoria de análise pode funcionar como uma importante aliada na historicização do Brasil e de suas contradições políticas.

\footnotetext{
${ }^{73}$ Currículo Lattes: http://lattes.cnpq.br/8181398550383569.

${ }^{74}$ Currículo Lattes: http://lattes.cnpq.br/3838221588289298.
} 
Palavras-chave: Pensamento social brasileiro. Florestan Fernandes. Revolução burguesa. Democracia.

\section{Introdução}

A trajetória de Florestan Fernandes contribuiu significativamente para o desenvolvimento da sociologia científica no Brasil, revelando um sociólogo preocupado com o dever de agregar responsabilidade científica e responsabilidade social do cientista (CARDOSO, 1996, p.92-93). O autor desenvolveu estudos acerca da particularidade das organizações capitalistas na América Latina entre as décadas de 1950 e $1960 .{ }^{75}$ A elaboração de novas problemáticas, na tentativa de produzir meios para entender a especificidade do subdesenvolvimento latino-americano, possibilitou a Fernandes a criação de um conjunto teórico em torno do nominado capitalismo dependente. Essa concepção teórica é ainda mais aprofundada e amadurecida na obra que é protagonista neste trabalho.

De acordo com a proposta em discussão, é necessário considerar alguns elementos que influenciam a existência e o caráter de democracia no Brasil, tais como: a sociedade civil organizada, as características da burguesia nacional, o imperialismo e a autocracia. Em conjunto, esses dispositivos revelam uma estrutura que restringe a democracia à burguesia, tornando-a um privilégio de classe nas concepções de Fernandes. A efetividade do valor democrático é uma especificidade do capitalismo dependente nas periferias do capitalismo, e entender esse conceito de democracia, bem como compreender o

\footnotetext{
${ }^{75}$ A obra "Circuito Fechado: quatro ensaios sobre o poder institucional" (FERNANDES, 2010) teve sua primeira edição em 1976, reúne quatro textos de Florestan Fernandes escritos entre 1966 e 1976 em que o autor já desenvolvia constructos teóricos sobre os aspectos do capitalismo na América Latina, sendo estes estudos anteriores a publicação da obra Revolução Burguesa no Brasil: ensaio de interpretação sociológica, que é foco do presente trabalho.
} 
movimento estrutural para produzi-la, cria condições teóricas para analisar de forma prática e profunda a conjuntura econômica, política e social do país. Trata-se de uma conjuntura que apresenta um quadro da realidade brasileira imersa em uma crise econômica profunda, em desigualdade social, em precarização do trabalho e em uma variedade de mazelas da questão social.

Desse modo, o presente trabalho é resultado do encerramento que marca as trajetórias acadêmicas dos autores no grupo de pesquisa Capitalismo dependente e políticas sociais: tensões e contradições, ao longo dos anos de 2019 e 2020. O encerramento desse grupo representa dois anos de intensas horas de estudos em torno da problemática centralizadora: quais são as particularidades do capitalismo brasileiro que fazem com que políticas sociais de caráter neoliberal sejam percebidas como um avanço histórico-social quando, na história das políticas públicas no modo de produção capitalista, podem ser consideradas um retrocesso? Embora esse artigo seja uma investigação conceitual, que aparentemente não aborda diretamente o neoliberalismo à brasileira, essa percepção inicial fica apenas na superfície da compreensão dessa proposta de pesquisa.

Quando pautamos a democracia, estamos pensando em um tema central de diversos posicionamentos sobre a realidade, com desdobramentos diretos nos aspectos políticos e econômicos. Pensar no neoliberalismo em qualquer lugar do mundo nos direciona para compreender quais as perspectivas sobre sociedade, políticas públicas e participação civil nas decisões centrais da sociedade. Portanto, quando a pauta é neoliberalismo, assume-se ou define-se uma compreensão a respeito de democracia. Considerar a realidade brasileira envolve entender de modo macroestrutural o desenvolvimento social dos países da América Latina e as especificidades que caracterizam as organizações sociais de cada um. 
Durante esses dois anos de discussão entre professores e estudantes, com formações que transitam entre as Ciências Socias, o Direito, o Serviço Social e a História, encontramos em Florestan Fernandes subsídio teórico denso para tratar do problema unificador dos sujeitos em nosso grupo de pesquisa. Dessa forma, reservamo-nos a considerar especialmente as produções desse sociólogo entre os fins da década de 1960 e ao longo da década de 1970, por considerar que as perspectivas dessas obras nos respaldam adequadamente em nossa busca.

Esse artigo tem como objetivo geral: analisar a concepção de democracia na obra Revolução Burguesa no Brasil: ensaio de interpretação sociológica, de Florestan Fernandes, e relacionar a democracia restrita, como categoria de análise na particularidade brasileira do capitalismo. O estudo será dividido em duas partes, no primeiro momento, será localizado o conceito de democracia na obra já especificada, delimitando, primeiramente, o conceito democrático no contexto brasileiro e, posteriormente, verificando a existência de níveis de acesso à estrutura democrática. No segundo momento, serão tratados os conceitos anexos à concepção democrática de Florestan Fernandes, tais como: a sociedade civil organizada, as características da burguesia nacional, o imperialismo e a autocracia. Esses fatores articuladamente organizados criam e mantêm uma estrutura favorável à democracia típica de países situados nas periferias do capitalismo.

Optou-se por realizar um direcionamento de análise partindo do objeto de estudo, que é o conceito de democracia na obra em questão, para posteriormente situá-lo no contexto maior da obra, tratando dos elementos anexos à ideia central. A escolha dessa metodologia tem por objetivo dar ênfase ao objeto estudado, propor um recorte mais preciso ao objeto considerando a amplitude e a complexidade da obra de 
Fernandes e por fim, proporcionar para o leitor uma compreensão do fenomênico para a totalidade.

\section{Conceito de democracia para Florestan Fernandes na obra Revolução Burguesa no Brasil: ensaio de interpretação sociológica.}

$\mathrm{Na}$ tentativa de construir uma estratégia para explicar o conceito de democracia para Florestan Fernandes na obra Revolução Burguesa no Brasil: ensaio de interpretação sociológica, opta-se por realizar dois movimentos metodológicos correlacionados: a definição dos valores democráticos no contexto brasileiro e a verificação dos níveis de acesso à democracia na sociedade de classes sob o prisma teórico do autor.

Segundo Cardoso (1996), desde a década de 1950, Florestan Fernandes desenvolvia conceitos que alicerçavam o entendimento sobre o capitalismo na América Latina e a sociedade de classes, sendo a democracia um desses aportes teóricos. O autor trata esse conceito atrelado a um conjunto de elementos, dentre eles: a sociedade civil organizada, as características da burguesia nacional, o imperialismo e a autocracia. Esses dispositivos combinados revelam uma estrutura de democracia restrita à burguesia, sendo essa uma especificidade do capitalismo que ocorria no Brasil. Cada um desses elementos será analisado posteriormente.

A questão democrática na obra em análise é pensada no contexto de capitalismo dependente. Por hora, é possível definir brevemente o conceito de capitalismo dependente, pois terá um enfoque mais apropriado em um segundo momento desse artigo. Em sua tese, Florestan Fernandes refuta a ideia de subdesenvolvimento da 
América Latina, considerando a função de produção e economia de tais países no cenário do capitalismo no âmbito global. O capitalismo praticado na América Latina se apresenta tutelado pelos países de capitalismo central, com a produção estrategicamente compatível ao posicionamento que ocupam. O fator econômico, ligado diretamente à financeirização externa, impacta sobre o fator social e político alinhando-os no mesmo movimento de dependência.

Dentro do quadro explicitado acima, o valor democrático latinoamericano não carrega o mesmo espírito burguês, como nos países que passaram por revoluções burguesas clássicas; o que não poderia ser diferente, já que se tratam de ambientes distintos e condições históricas adversas. Nesse caso, a democracia se caracteriza por ser restrita e se tornar um dos muitos privilégios da burguesia. Cardoso (1996, p.122-123) aponta como um dos elementos para explicar a democracia restrita a relação entre dependência e democracia que Florestan Fernandes aborda em alguns textos, como no texto Sociedade de Classes e Subdesenvolvimento (2015). A condição de dependência dos países da periferia é analisada no nível externo e interno. No nível externo, está ligada ao caráter fundamental do posicionamento na organização da civilização ocidental e a função que desempenham na acumulação de capital dos países de capitalismo central, com seu subdesenvolvimento tutelado em uma relação heteronômica.

No nível interno, a característica dependente determina uma ordem social injusta, que exclui a maioria da população, realizada por mecanismos diversos produzidos nas esferas social, econômica e política, restringindo a efetivação de direitos a uma determinada classe e conferindo o caráter de restrição e privilégios de outra. Esse é um movimento que ocorre mesmo em um contexto de ordem social do modo de produção capitalista que, teoricamente, tem como base a 
democracia no seu caráter universal e participativo. No aspecto do privilégio,

[...] apesar das instituições e dos valores sociais vigentes, a ordem legal criada pela República não abrange, equitativamente, todas as camadas sociais de todas as regiões do País. Tudo se passa como se os direitos e as garantias sociais, assegurados por essa ordem legal, fossem privilégios inconfundíveis das minorias que possuem condições econômicas, sociais e políticas para desfrutá-los e como se fosse indiferente, para a existência e para o futuro de uma sociedade nacional, que três quartos da sua população estivessem parcial ou totalmente banidos de suas estruturas de poder. (Fernandes apud Cardoso, 1996, p. 123)

Em um trecho posterior da mesma obra, Sociedade de Classes e Subdesenvolvimento (1967), o autor sustenta que nenhuma nação pode construir um destino nacional apoiada em desigualdade e exclusão sistemática, que é consequência da estrutura democrática restrita. A destruição de estamentos e grupos privilegiados é um fator fundante para a constituição de uma sociedade nacional que, dessa forma, pode assumir um querer coletivo para produzir seus próprios meios de conquista de autonomia das outras sociedades de capitalismo central.

Fernandes utiliza a exposição da relação de dependência entre os países de capitalismo central e países de capitalismo periférico para destacar as influências dessa relação na sociedade e as estruturas antidemocráticas que elas edificam. Os interesses externos justificados pelos fatores econômicos incidem diretamente na relação interna entre as classes, direcionando os interesses internos e repercutindo nas condições de produção e reprodução da classe trabalhadora. Na obra Revolução Burguesa no Brasil: ensaio de interpretação sociológica, Florestan Fernandes aprofunda seu pensamento sobre a relação de capitalismo dependente e democracia com uma lógica de dupla 
articulação, que ele define como dominação imperialista externa e desenvolvimento desigual interno.

A dupla articulação mencionada, além de contribuir para a produção da especificidade democrática do contexto dependente, também condiciona os níveis de acesso a essa democracia, sendo responsável pela criação de uma estrutura de sobre-exploração e sobre-expropriação. Com o intuito de manter a lógica capitalista de acumulação de capital para a burguesia interna e externa, as demais classes sofrem o aprofundamento das condições de acumulação de forma mais acentuada que, por fim, proporciona uma forma peculiar de dominação burguesa. A relação existente entre o capitalismo dependente e os níveis de democracia exercida nesse contexto é diretamente exposta por Cardoso:

Indico-o e sublinho o que me parece ser o rumo principal da argumentação de Florestan: se a expropriação do trabalho é o fundamento do capitalismo enquanto modo de produção, a democracia burguesa também é essencial para o funcionamento do modo de produção capitalista e o controle das suas crises. Na especificidade dependente do capitalismo, porém, o seu fundamento é drasticamente exagerado, convertendo-se em sobre expropriação, ao que corresponde a também drástica redução da democracia que o acompanha, que se restringe ao ponto de uma democracia de iguais. Deste modo, o capitalismo dependente se concretiza através de sobre expropriação e de autocracia, caracterizando o que Florestan Fernandes denomina capitalismo selvagem. Conjuga crescimento econômico dependente com miséria e exclusão despóticas, além da ausência de direitos fora dos setores sociais dominantes (CARDOSO, 1995, p. 5).

A sobre-expropriação e também a sobre-exploração regulam a medida dos dispositivos democráticos nos países dependentes. A democracia, que em países de capitalismo central também tem a função de conter as crises do próprio capitalismo, não pode sequer ser exercida nos países de capitalismo periférico, produzindo um cenário propício para um Estado autocrático, com sensações democráticas, 
mas sem acesso efetivo a direitos, poder e riqueza socialmente produzida, imputando níveis elevados de exploração e expropriação para as demais classes.

A progressiva relação de dependência tensiona conflitos entre as classes e reforça diferenciações de estratos de classe que direcionam as relações de poder, as participações sociais, institui direitos e organiza a legislação, ou seja, proporciona a vinculação do aparato democrático às classes e estratos de classe burguesas. Nesse contexto, Fernandes chama atenção para o movimento de cooptação que pode ser relacionado com a existência de níveis de acesso à democracia. A democracia de cooptação se dá no movimento realizado pela burguesia de sobrepor a sociedade civil à Nação. Na sociedade civil, se constitui o consenso burguês que, em um sistema essencialmente democrático, legitimar-se-á pelo consentimento das outras classes e transformar-se-á no consenso da Nação. Já na peculiaridade brasileira, legitima-se pelo Estado autocrático e pela dominação burguesa, pois, de acordo com Fernandes:

[...] as classes e estratos de classe "conquistavam" uma unidade, que não passava nem pelas demais classes, nem pelas estruturas políticas extraburguesas da Nação, mas que Ihes conferia, não obstante o controle concreto da ordem legal e política, bem como a possibilidade histórica de sobreporem a sociedade civil à Nação. Tal alteração, que se precipita com incrível rapidez, modifica por completo o significado de hegemonia burguesa e, principalmente, suas funções políticas, neutralizando suas raízes artificiais e compensando seu precário fundamento sociopolítico [...] ao sobreporem a sociedade civil à Nação equipararam, de fato, sua própria democracia restrita a uma oligarquia das classes burguesas dominantes. (1976, p. 358)

As relações políticas entre os mais iguais resultantes desse quadro geram a cooptação de grupos, facções e classes por meio de 
corrupção do sistema de poder. A cooptação movimenta o conflito de interesses e valores na cena política, o que poderá ou não resultar em apoio para os interesses em questão. Fernandes aponta que a autocracia burguesa, por meio do Estado autocrático, leva à democracia restrita, que pode significar também democracia de cooptação e ainda condicionar às classes as possibilidades de alcance de privilégios travestidos de aspectos democráticos.

A democracia de cooptação também se abre para as demais classes, segundo Fernandes, e por meio de acesso à mobilidade social e prática de corrupção, e "permitem estender as fronteiras da 'consciência burguesa' e da condição burguesa dentro das classes operárias e das classes destituídas" (Fernandes, 1976, p. 364). Por outro lado, o autor destaca que a democracia de cooptação não é eficaz nem flexível em países de capitalismo dependente e pobres, por conta da burguesia nacional não possuir largo excedente para compra de alianças e fortalecimento de apoio, devido à grande concentração de renda. Nesse sentido, a cooptação contribui para o aumento de desigualdade e para a acentuação das contradições inerentes à sociedade e ao regime de classes, tensionando as relações entre as mesmas. Fernandes aponta que esse movimento mais enfraquece do que fortalece o Estado autocrático, pois é direcionado a "funcionar sob extrema tensão permanente e autodestrutiva, de insuperável paz armada" (Fernandes 1976, p. 365). Perez (2019) considera essa tendência como indicativo para compreender o período final da ditadura aberta de classes que pode ser ocasionada por conta da distensão que congregou autocracia e democracia de cooptação.

Para Florestan Fernandes, os movimentos de análise da definição de democracia no contexto de capitalismo dependente, bem como a verificação de níveis de acesso à democracia que se foi proposto a realizar, mostram-se concluídos aqui, porém, não 
esgotados. O autor se aprofunda na particularidade brasileira de capitalismo, constando que a democracia é restrita às classes burguesas e os níveis de acesso são influenciados por fatores internos e externos e por um Estado autocrático. Outros elementos que contribuíram para a criação e perpetuação dessas condições serão tratados na sequência.

\section{Relação da categoria de democracia restrita à apreensão da particularidade brasileira.}

Após a realização da análise sobre a concepção de democracia restrita sob o prisma teórico de Florestan Fernandes, o foco do estudo se volta a alguns elementos que influenciam a existência e o caráter democrático no Brasil. Os elementos são: a sociedade civil organizada, as características da burguesia nacional, o imperialismo e a autocracia. Alguns deles já foram citados, mas recebem especial atenção neste momento do estudo. Também se mostra importante referenciar a obra de Florestan Fernandes, foco desse trabalho, por conta de sua grande relevância tanto na trajetória do autor como para a sociologia brasileira.

Escrita como ensaio, a obra Revolução Burguesa no Brasil: ensaio de interpretação sociológica foi iniciada em 1966 com intuito de oferecer uma resposta intelectual à situação política acentuada no regime militar, e foi terminada em 1974, também como um reposicionamento crítico do autor, com a primeira publicação no mesmo ano. Em sua nota explicativa da primeira edição, é possível perceber a preocupação de Florestan Fernandes com seu posicionamento enquanto autor, que é a inevitável fundição do sociólogo e socialista militante. A trajetória profissional de consistente 
expressão acadêmica, sua atuação política e social, os anos no exílio forçados em decorrência da ditadura civil-militar compõem o referido posicionamento do autor. Nessa perspectiva, Florestan Fernandes realiza sólidas contribuições teóricas em uma diversidade de campos sociológicos em suas obras. Especificamente na obra foco, o autor explicita sobre as principais linhas da evolução do capitalismo e da sociedade de classes no Brasil.

Nas décadas em que Fernandes iniciou seus estudos sobre capitalismo dependente, o pensamento social de maior força acerca da compreensão sobre Brasil era de um país que estava passando por um processo de desenvolvimento. Portanto, existia a perspectiva de que, com ampliação e aceleração da indústria, o Brasil alcançaria o mesmo nível de desenvolvimento econômico e social dos países de capitalismo central. Nessa conjuntura, o fator econômico era visto como primordial para alcançar o objetivo, e que os outros fatores, como o social e o político, teriam seu desenvolvimento a reboque desse. Os interesses econômicos deveriam ser alinhados aos interesses dos países de capitalismo central, fortalecidos por uma política que propiciasse e que garantisse tais interesses, mesmo que causassem grande impacto na ordem social, acirrando conflitos de classe. Os problemas sociais, causados pela desigualdade que se aprofundava como consequência dessa política econômica pró-imperialista, eram vistos como empecilho para o desenvolvimento, mas que seriam resolvidos automaticamente ao alcançar seu objetivo.

Nos estudos de Fernandes, e principalmente nessa obra (1976), o autor caminhou na contramão desse pensamento, apontando a situação de subdesenvolvimento do Brasil, com suas especificidades por conta do tipo de capitalismo praticado nos países de capitalismo periférico. Tendo como referência as revoluções burguesas clássicas, o autor indica a inabilidade e debilidade da burguesia nacional de guiar 
o desenvolvimento em um processo autônomo, ou até mesmo de criar condições históricas para uma revolução, que trouxesse consigo a autonomia e, por consequência, a democracia. Aponta o movimento de contrarrevolução e o fortalecimento de uma relação de dependência com os países de capitalismo central, mais precisamente com os interesses da burguesia nacional alinhados com a burguesia desses países, colocando todo o aparato econômico e político a esse serviço.

Pensando nas características da burguesia que influenciam a democracia restrita no capitalismo dependente, há que se considerar a formação dessa burguesia com traços marcantes da junção do moderno com o arcaico. Fernandes apontou os grupos que formaram essa burguesia desde antes da independência brasileira. $\mathrm{Na}$ diferenciação desses grupos e na sua acomodação, fica clara a presença dessa contradição para manter o controle do poder e a garantia dos interesses na formação da burguesia nacional, que, desde o início, foi tutelada externamente e comprometeu o desenvolvimento interno. A modernização conservadora da burguesia foi direcionada por conveniência, sendo conservadora nos aspectos democráticos, causando, dentre outros fatores, o esvaziamento do espírito burguês. Desse modo, influencia diretamente a construção dos valores democráticos.

As características da burguesia nacional causam diferentes prejuízos para si quanto ao seu posicionamento e para as demais classes no aspecto democrático conforme

[a]s inconsistências das burguesias latino-americanas procedem do fato de que elas resistem à plebeização e instigam a proletarização sem querer aceitar a democratização correspondente da ordem social competitiva. Proscrevendo o destituído da ordem civil e limitando (ou anulando) a participação econômica, cultural e política das classes trabalhadoras, aquelas burguesias enfraqueceram a si próprias, reduzindo suas alternativas, empobrecendo sua 
visão do mundo e liquidando-se como agente histórico revolucionário. (CARDOSO, 1995, p.8)

A burguesia nacional é fechada em si mesma, conforme é possível pensar que "as classes burguesas continuam tão presas dentro dos seus casulos, isoladas da realidade política de uma sociedade de classes e submetidas a partir de fora" (FERNANDES, 1976, p. 354). Coloca-se num movimento em que se fundem a sobrevivência como classe e a sobrevivência do próprio capitalismo dependente. Dessa forma, ela deve manter seu status quo dentro da relação de dependência, que se mostra forte internamente, por meio do Estado autocrático, e débil externamente, por conta do seu estado heteronômico na relação com as burguesias externas e fortalecidas dos países de capitalismo central. A incapacidade e a falta de interesse da burguesia nacional em produzir condições para a conquista da sua autonomia externa e direcionar o seu próprio desenvolvimento interno fortalece a estrutura da democracia restrita à sua própria classe.

Outro dispositivo que está na base estrutural da democracia restrita no Brasil é a sociedade civil organizada. Na obra em questão (1976), Fernandes utiliza essa categoria como o modo institucional que se interliga com as concepções de cidadania. Considerando a especificidade da democracia restrita, as classes que exercem seus direitos são as classes e estratos de classes burguesas e, em diferentes níveis, as classes que são cooptadas, como foi descrito anteriormente. Nesse sentido a sociedade civil organizada é a parcela válida da sociedade que contribui para a manutenção da ordem societária.

É importante destacar que a sociedade civil organizada é necessariamente fundamentada em uma classe que possui consciência de classe, dispondo de condições materiais e ideológicas para fazer valer seus interesses de classe, que pode ser refletido na conquista, manutenção ou ampliação de poder. No recorte em que tratamos a 
sociedade civil organizada, significa uma parcela válida da sociedade que exerce direitos, que protege a ordem e a civilização cristã ocidental, contribuindo para o desenvolvimento do país nas condições determinadas pelo capitalismo dependente. $\mathrm{Na}$ peculiaridade brasileira, a consolidação da sociedade civil organizada é realizada com a sobreposição dos interesses da burguesia aos interesses da Nação, conforme Fernandes,

[...] é evidente que o consenso burguês concilia a "tradição brasileira" de democracia restrita - a democracia entre iguais, isto é, entre os poderosos, que dominam e representam a sociedade civil - com a "orientação modernizadora" de Governo forte. A ordem legal e política se mantém "aberta", "democrática" e "universal", preservando os valores que consagram o Estado de direito; e este Estado se concretiza, historicamente, por sua vez, na medida em que tudo isso é necessário à monopolização do poder real, da autoridade e do controle das fontes de legitimidade pelas classes burguesas e suas elites. (FERNANDES, 1976, p. 347).

O autor demonstra o papel da sociedade civil organizada, com destaque para a burguesia, na democracia restrita por meio do consenso burguês. Em um mesmo movimento, destaca como a burguesia consegue alçar os seus interesses acima dos interesses da Nação e os caracteriza como um desejo nacional, sendo possível pela força da legitimação pelo Estado. Esse Estado, por sua vez, se qualifica como autocrático ao conjugar aparente democracia com real controle e monopolização do poder das classes e estratos de classes burguesa.

O imperialismo como fator estruturante da democracia restrita, na especificidade de capitalismo dependente, ocorre pela dupla articulação. Como já tratado, a dupla articulação conjuga o desenvolvimento desigual interno e a dominação imperialista externa, que só é possível pelas características da burguesia nacional. 0 movimento de dupla articulação acentua as desigualdades sociais, a 
acumulação de riqueza para as burguesias internas e externas e a relação de dependência. O autor destaca a apropriação e a exploração dual do excedente sofrida pelos países de capitalismo dependente que é exercida pela burguesia interna e externa, causando enorme impacto sobre o que Fernandes chama de padrão imperializado, dependente e subdesenvolvido de desenvolvimento capitalista que agrava fatores sociais e políticos em uma singular dominação. Como destaca Fernandes:

\begin{abstract}
A extrema concentração social da riqueza, a drenagem para fora de grande parte do excedente econômico nacional, a consequente persistência de formas pré ou subcapitalistas de trabalho e depressão medular do valor do trabalho assalariado, em contraste com altos níveis de aspiração ou com pressões compensadoras à democratização da participação econômica, sociocultural e política produzem, isoladamente e em conjunto, consequências que sobrecarregam e ingurgitam as funções especificamente políticas da dominação burguesa (quer em sentido autodefensivo, quer numa direção puramente repressiva)[...]. (1976, p. 292-293)
\end{abstract}

Esse quadro social, político e econômico demonstra exatamente os impactos do imperialismo, produzido pela dupla articulação, no acesso à democracia pela classe proletária. A burguesia, que se sobrepõe à Nação por meio de mecanismos que já foram tratados anteriormente, utiliza o Estado para legitimar, proteger e efetivar seus interesses, por meio de repressão em vários aspectos, tornando-o assim em um Estado autocrático.

De acordo com Cardoso (1995), as sociedades de classes, nas especificidades do capitalismo dependente não são compatíveis com a acessibilidade de direitos para todas as classes, pelo contrário, ela resulta em democracia restrita no Estado autocrático burguês. 0 capitalismo dependente e a autocracia são decorrentes de dois fatores. O primeiro, das vantagens da burguesia interna advindas dos 
alinhamentos às burguesias de países de capitalismo central. Segundo, da totalidade do controle do poder para a garantia do desenvolvimento, mesmo em oposição às condições de sobrevivência das outras classes e sua organização política.

Por meio do Estado autocrático, a burguesia legitima seus interesses, direciona o desenvolvimento interno e, acima de tudo, exerce o controle necessários para a manutenção da ordem societária. Um controle que pode ocorrer pela repressão violenta e física com o apoio do aparato militar, e também por meio de política de classe, no acesso a direitos e à riqueza socialmente produzida, ou seja, garantindo a manutenção do poder que passa pelos aspectos sociais, políticos e econômicos que pode refletir na democracia de cooptação, como já tratado anteriormente. O Estado autocrático

[p]reserva estruturas e funções democráticas, mas para os que monopolizam, simultaneamente, 0 poder econômico, o poder social e o poder político, e usam o Estado exatamente para criar e manter a dualidade intrínseca da ordem legal e política, graças à qual o que é oligarquia e opressão para a maioria submetida, é automaticamente democracia e liberdade para a minoria dominante. (FERNANDES, 1976, p. 350)

Fernandes denomina de capitalismo selvagem o sistema que combina expropriação dual e autocracia, capaz de produzir acumulação em níveis extremos, com desenvolvimento econômico dependente, e pobreza sistemática, com exclusão democrática dos níveis mais baixos de classe. Nesse sentido, coloca-se em xeque a sociedade e classes, pois "a autocracia, ao deprimir e tentar anular esse conflito e esse confronto [entre as classes sociais], acaba por cercear as transformações, mesmo as que são próprias do desenvolvimento capitalista" (CARDOSO, 1995, p.8). Dessa maneira, não há condições de competitividade entre as classes, colocando em risco a 
sobrevivência das mesmas, seja da classe burguesa, pelo seu impasse causado pela heteronomia externa e desgaste em manter o Estado autocrático, seja da classe trabalhadora, cada vez mais expropriada de direitos e condições de reprodução. Portanto, significa também a sucumbência do próprio capitalismo dependente.

\section{Considerações finais}

Ao final desse trabalho fundamentalmente bibliográfico, é possível concluir que a democracia, sobre as considerações de Fernandes (1976), é essencialmente restrita e, para abordá-la adequadamente, faz- se necessário o uso de outros dispositivos teóricos situados pelo autor. A mobilização teórica em torno da busca pela particularidade de um conceito do sociólogo escolhido para essa análise obriga a compreender outros conceitos e categorias de análise que, nesse caso, são: a sociedade civil organizada, as características da burguesia nacional, o imperialismo e a autocracia. Para acessar a ideia de democracia restrita, presente em A Revolução Burguesa no Brasil: ensaio de uma interpretação sociológica (1976), fez-se necessário o uso de comentaristas acerca da trajetória teórica de Florestan Fernandes. O referido autor se mostra como um pensador altamente comprometido com os estudos sobre o Brasil, desde suas investigações sobre a guerra e a sociedade tupinambá (FERNANDES, 2006) ao ensaio sociológico que cria uma tese sobre a particularidade política e econômica do Brasil na organização capitalista (1976).

Conforme mencionado os campos de estudo de Florestan Fernandes são muito vastos e para compreender a visão deste sobre Brasil, tornou-se necessário delimitar temporalmente uma obra que ofereça riqueza de articulações práticas (sob o ponto de vista da análise social). Como o capitalismo dependente faz parte integrante dos conceitos utilizados para compreender as particularidades brasileiras 
do neoliberalismo no Brasil, pelos autores desse artigo no grupo de pesquisa Capitalismo dependente e políticas sociais: tensões e contradições, a opção por uma discussão da obra A Revolução Burguesa no Brasil: ensaio de uma interpretação sociológica (FERNANDES, 1976) se mostrou um encontro certeiro. Embora a temática do neoliberalismo não apareça como foco central nesse texto, parte-se do pressuposto de que o conhecimento sobre o Brasil em seus aspectos históricos torna possível uma compreensão sobre as estruturas econômicas e políticas que dão as especificidades para um neoliberalismo brasileiro. Nesse sentido, esse texto é um ensaio a respeito de teorias que juntas estruturam a tese de Florestan Fernandes a respeito da particularidade do Brasil na organização capitalista.

Ao final dessa investigação é possível afirmar que o problema central, concentrado na investigação acerca da concepção de democracia para Fernandes na obra A Revolução Burguesa no Brasil: ensaio de uma interpretação sociológica (1976), foi respondido. O tratamento de Fernandes para a questão democrática foi essencialmente marcado pela organização dos dispositivos analíticos que o mesmo construiu para a América Latina desde a década de 1960, com reflexões marcantes a respeito das instituições (FERNANDES, 2010) para as noções de classe social e subdesenvolvimento (FERNANDES, 2015).

Embora esse formato de pesquisa exija um compromisso com as interpretações mais consagradas a respeito de um autor e sua obra, os comentaristas escolhidos para compor a busca centralizadora desse artigo cumprem a função de ambientar e fortalecer a leitura sobre Fernandes debatida ao longo de dois anos no grupo de pesquisa mencionado anteriormente. Não se trata de negar a produção sociológica no campo do pensamento social, mas envolve propor uma 
investigação que parta da obra de Florestan Fernandes (1976) e se respalde em estudos que ajudam a compreendê-la e não em criar uma filosofia historiográfica em torno dos debates acadêmicos sobre o sociólogo. Nesse sentido, foi fundamental a caminhada acadêmica que configurou dois anos de intensos debates em grupo com professores e estudantes na compreensão do estado brasileiro e suas particularidades sob a perspectiva de uma expressão do capitalismo considerada dependente (FERNANDES, 1976).

O olhar que Florestan oferece sobre a organização do Estado brasileiro é essencialmente sociológico, por identificar os laços societários se apropriando de conceitos que versam sobre as revoluções liberais clássicas para historicizar o Brasil na compreensão de suas especificidades nas contradições do Capital. Contudo, a discussão sobre a especificidade brasileira na questão democrática não se esgota nessa análise, pois mesmo compreendendo as diversas categorias que Fernandes (1976) dispôs para tal, o tema é altamente relevante no cenário atual. Com o abismo temporal entre a obra escolhida para essa investigação e a atualidade, é possível perceber a série de acontecimentos marcantes na História do Brasil recente, desde a redemocratização (iniciada em 1985), que demonstra a relevância da compreensão do conceito e da prática de democracia, bem como a prática autocrática visível em diversas posturas nas disputas políticas que tornam relevante a ideia de uma restrição democrática no Estado brasileiro. Dessa forma, encerramos esse texto sem qualquer ambição de pontuar resposta objetiva para os diversos problemas que permeiam as questões política atuais, mas de resgatar a intelectualidade nacional como um exercício árduo de imersão teórica, acreditando que isso seja um movimento muito concreto em torno da compreensão do Brasil. 


\section{REFERÊNCIAS}

CARDOSO, M. L.. Florestan Fernandes: a criação de uma problemática. In: Estud. av., São Paulo, v. 10, n. 26, p. $89-128$, abr.
<http://www.scielo.br/scielo.php?script=sci_arttext\&pid=S0103-

$40141996000100014 \&$ Ing=pt\&nrm=iso>. Acesso em: 17 set. 2020.

CARDOSO, M. L.. Capitalismo dependente, autocracia burguesa e revolução social em Florestan Fernandes. "Coleção Documentos", Instituto de Estudos Avançados - USP. São Paulo, 1995. Disponível em: <http://www.iea.usp.br/publicacoes/textos/limoeirocardosoflorestan1.pdf>. Acesso em: 22 set. 2020.

FERNANDES, F.. A função social da guerra na sociedade tupinambá. 3. ed. Porto Alegre: Globo, 2006.

FERNANDES, F.. A Revolução Burguesa no Brasil: ensaio de uma interpretação sociológica. Rio de Janeiro: Zahar Editores, 1976.

FERNANDES, F.. Circuito fechado: quatro ensaios sobre o "poder institucional". São Paulo: Globo, 2010. FERNANDES, F.. Sociedade de classes e subdesenvolvimento. São Paulo: Global Editora, 2008.

PEREZ, D. M.. Capitalismo dependente, autocracia burguesa e democracia de cooptação: o golpe de 2016 e a atualidade de Florestan Fernandes. In: Temporalis, Brasília (DF), n. 37, p. 10-25, jan.-jun. 2019. Disponível em: <https://periodicos.ufes.br/temporalis/article/view/24232>. Acesso em: 22 set. 2020. 


\title{
A COMOÇÃO ENQUANTO UMA ATITUDE ÉTICA: REFLEXÕES SOBRE SENTIMENTOS NA POLÍTICA A PARTIR DA CRÍTICA FEMINISTA
}

\author{
Flávia da Rosa Melo76 \\ Flora Morena Maria Martini de Araujo 77
}

Resumo: Judith Butler (2015) em um dos seus recentes trabalhos defende que nosso foco, enquanto pesquisadores e pesquisadoras acadêmicas vinculadas aos estudos de gênero, deve ser também pensar quais são os "modos culturais de regular as disposições afetivas e éticas por meio do enquadramento seletivo e diferenciado da violência" - seja ela física, psicológica, racial, sexual, geracional, de classe ou de gênero. Tal perspectiva filosófica coaduna-se com um esforço presente em outras áreas das Ciências Humanas, nas quais especialistas defendem a produção de reflexões sobre os fatos relativos às sensibilidades políticas que não sejam movidos apenas pelo esforço de explicação e racionalização, pois, dessa forma, reincidem em negligências acerca da dimensão afetiva e passional das relações políticas e intersubjetivas. Articulamos nossa análise com a produção de intelectuais como Yves Cohen, Pierre Ansart, Donna Haraway, Hasana Sharp, Judith Butler e Stella Bresciani, por exemplo, para, neste trabalho, refletirmos a respeito de como uma parte da crítica teórica feminista e dos estudos de gênero recentes abordam a reflexão sobre a vida, o luto e a comoção, considerando o que tais estudiosas oferecem enquanto ferramenta teórica e conceitual para (re)pensarmos a ética, a

${ }^{76}$ Currículo Lattes:
77 http://lattes.cnpq.br/8817803783991750. 
História, a prática historiográfica e os sentimentos na política na contemporaneidade.

Palavras-chave: Sentimentos na política. Crítica feminista. Judith Butler.

Introdução

Para considerar a questão da capacidade de sobrevivência em situação de guerra e, nisso, o local da comoção, Judith Butler usa poemas escritos em Guantánamo como fonte em um de seus estudos. De partida, é interessante ressaltar que estes textos só se tornaram conhecidos de um grande público após uma triagem do governo estadunidense: só foram publicados aqueles textos que, após uma rigorosa seleção, não foram considerados perigosos à nação.

Poemas muitas vezes escritos em copos plásticos ou guardanapos exigiram, portanto, um estudo e uma reflexão de fôlego a respeito dos riscos que poderiam trazer ao serem lidos por um grande público. Butler é bastante feliz ao ponderar sobre o que poderia conter de tão grave nesses poemas, que configurariam um perigo à unidade nacional, a ponto de a maioria ter sido destruída por militares.

Seria a forma, o conteúdo..., o que poderia fazer dessa poesia algo tão particularmente perigoso? Seus autores eram homens que estavam presos, a maioria sob a acusação de terrorismo. Eram sobreviventes das mais variadas formas de tortura: como eles conseguiam ser tão perigosos também com sua poesia? A autora levanta várias possibilidades para tal, sendo uma das mais emblemáticas a de que aqueles poemas recorrem à paz (e não à guerra ou à violência) para abrir caminho, por meio de uma ou várias ideologias dominantes de poder e de afetividade, contestando e refletindo sobre a situação deles próprios e do que os levou até àquela condição de encarceiramento. A periculosidade de tais poemas se deve 
ainda por materializarem em mais de um formato como os corpos são estatutos precários de solidão. Um exemplo disto é o texto de Shaker Abdurraheem Aamerm que, segundo Butler, abre a coletânea:

Paz, eles dizem.

Paz de espírito?

Paz na Terra?

Paz de que tipo?

Eu os vejo falando, discutindo, brigando...

Que tipo de paz estão buscando?

Por que eles matam? O que estão planejando?

É apenas conversa? Por que discutem? Matar é tão simples assim? É esse o plano deles?

Claro que sim!

Eles conversam, eles discutem, eles matam -

Eles lutam pela paz. (AAMERM, apud BUTLER, 2015, p. 91)

Nesse sentido, vemos como os poemas para Butler podem se converter numa condição de capacidade de resposta, "de uma formulação da comoção entendida como um ato radical de interpretação diante de uma submissão indesejada." (BUTLER, 2015, p.88)

Assim, apresentamos como ponto de reflexão neste artigo uma consideração sobre uma relação entre (uma parte da) a crítica teórica feminista e os estudos de gênero, considerando o que eles oferecem enquanto ferramenta teórica e conceitual para pensar os sentimentos na política. Essa reflexão leva em conta a análise de Judith Butler em um dos seus recentes trabalhos, o qual defende que nosso foco, enquanto 
pesquisadores e pesquisadoras acadêmicas vinculadas aos estudos de gênero deve ser também pensar quais são os "modos culturais de regular as disposições afetivas e éticas por meio do enquadramento seletivo e diferenciado da violência" (BUTLER, 2015, p. 13) - seja ela física, psicológica, racial, sexual, geracional, de classe ou de gênero.

\section{E eu não sou uma mulher?: a problemática feminista do pária}

As filiações e problemáticas com as quais os feminismos e os estudos feministas na academia se ocupam têm um amplo escopo de temas. Todavia, dentre tais, a urgência de se questionar a categoria "mulher" não deixa de ser sempre atual. Desde o renomado estudo sobre a "mística feminina" (FRIEDAN, 1963), está posta a necessidade de refletirmos sobre os discursos e mobilizações políticas para os quais as mulheres são educadas, que tendem majoritariamente a acionar o local da dependência afetiva e responsabilidade sobre o núcleo familiar como central para que sejam mulheres, portanto, boas esposas e mães afetuosas.

O incômodo percebido por Friedan com a ideia de "mulher" e os determinantes que o circundam tem, portanto, uma longa e complexa trajetória. Entendemos que também as imposições acerca de ser mulher demonstram uma manifestação da comoção como ato radical de interpretação face a uma submissão indesejada. Ainda que tais contestações e elaborações político-filosóficas tenham sido centrais para a segunda onda do movimento feminista e para o desenvolvimento da crítica feminista acadêmica surgida no século $X X$, tais reflexões não surgiram somente naquele contexto. A percepção sobre as diferenças impostas sobre o feminino advém de uma trajetória muito mais longa. A problemática da mulher como o outro pode ser remontada, por exemplo, às mulheres que frequentavam os cículos liberais e ilustrados do final do século XVIII, e 
também algumas abolicionistas do XIX.

No discurso que ficou conhecido pelo título de E não sou uma mulher?, a oradora abolicionista Sojourner Truth, discursando na Women's Convention em Akron, Ohio, Estados Unidos, em 1851, já questionava por meio da oratória as ideologias dominantes a respeito do ser mulher e dos direitos das mulheres. Em um trecho, Sojourner Truth disse:

Bem, crianças, onde há muita confusão deve haver algo de errado. Penso que entre os negros do Sul e as mulheres do Norte, todos falando sobre direitos, os homens brancos vão muito em breve ficar num aperto. Mas sobre o que todos aqui estão falando? Aquele homem ali diz que as mulheres precisam ser ajudadas a entrar em carruagens, e erguidas para passar sobre valas e ter os melhores lugares em todas as partes. Ninguém nunca me ajudou a entrar em carruagens, a passar por cima de poças de lama ou me deu qualquer bom lugar! E não sou mulher? Olhem pra mim! Olhem pro meu braço! Tenho arado e plantado, e juntado em celeiros, e nenhum homem poderia me liderar! E não sou uma mulher? Posso trabalhar tanto quanto e comer tanto quanto um homem - quando consigo o que comer - e aguentar o chicote também! E não sou uma mulher? Dei à luz treze filhos, e vi a grande maioria ser vendida para a escravidão, e quando eu chorei com minha dor de mãe, ninguém, a não ser Jesus me ouviu! E não sou uma mulher? ${ }^{78}$

Repetimos uma frase atribuída a Truth neste mesmo discurso: "Mas sobre o que todos aqui estão falando?" para estabelecer um modo explicativo a respeito de como pensar aqueles e aquelas que foram e são considerados e consideradas "a escória do mundo". Eleni Varikas lança mão do que ela chama de um "advento de significação": a figura do pária. Tal advento, uma metáfora que visa considerar também que a própria linguagem convive com contradições, exige, segundo a autora, que se

\footnotetext{
78 Discurso disponível em: https://www.nps.gov/articles/sojourner-truth.htm Tradução nossa do original. Acesso em: 29 janeiro de 2019.
} 
pense a história dessa figura em uma perspectiva genealógica. Quem é pária? O que é um pária? (VARIKAS, 2014, p. 70). O discurso de Soujourner Truth é, em nossa leitura, a manifestação de uma dessas figuras do pária, e, ao mesmo tempo, uma contestação retórica de uma mulher que questiona a lógica de comoção e de reconhecimento de gênero, raça e classe que é a dominante de seu tempo.

Truth também denuncia os enquadramentos e molduras culturais e sociais sexistas e racistas sob os quais o ser reconhecidamente mulher dizia respeito. Nenhum homem nunca a ajudou por ela ser mulher, "feminina", pouco apta ao trabalho pesado: ela não era branca, seria mulher? A dor de ver seus filhos vendidos para a escravidão não foi compartilhada. Seus filhos eram vidas humanas ou mercadorias, já que foram vendidos? A exposição do seu corpo à violência física do açoite não foi reconhecida enquanto injusta. Sua pergunta constante e retórica, - "E não sou uma mulher?" -, resposta contestatória ao outro conferencista, sua denúncia de que só Jesus a ouviu sofrer com sua dor, são manifestações do seu corpo enquanto forma de contestação e questionamento dos parâmetros de comoção e não-reconhecimento da dor e da violência vigentes. Butler afirma, a esse respeito, que:

Nós somos seres sociais, que trabalham em meio a interpretações
sociais elaboradas, tanto quando sentimos horror como quando não
o sentimos. Nossa comoção nunca é somente nossa: a comoção é,
desde o começo, transmitida de outro lugar. Ela nos predispõe a
perceber o mundo de determinada maneira, a acolher certas
dimensões do mundo e resistir a outras. [...] A comoção depende
de apoios sociais para o sentir: só conseguimos sentir alguma coisa
em relação a uma perda perceptível, que depende de estruturas
sociais de percepção, e só podemos sentir comoção e reinvidicá-la
como nossa com a condição de que já estejamos inscritos em um
circuito de comoção social. (BUTLER, 2015, p. 81-82).

A comoção e a capacidade de se comover com o ódio, o amor, a ira ou a humilhação são socialmente construídos e enquadrados, e não são 
distribuídos da mesma forma dentro de uma sociedade. Truth já fez tal denúncia, ainda no século XIX, usando a retórica como mecanismo de contestação de uma perspectiva de mundo intrinsecamente falha em sua proposta de universalidade: ao perguntar se ela não era uma mulher, ao questionar se apenas ela sentia a dor de ver seus filhos vendidos, a paixão de seu lamento, a indignação e o desejo de mudança na força política de sua retórica, Truth torna latente para nós a impossibilidade de pensar que a esfera da política - do racismo, do machismo e da misoginia - seja explicável por uma perspectiva exclusivamente racionalista.

Nos círculos acadêmicos da teoria política e dos estudos de humanidades em amplo espectro, as reflexões sobre como teorizar as paixões políticas e as imagens que evocam tais paixões - ou ódios - tiveram espaço e atenção crescentes em pesquisas nas últimas décadas do século $X X$. Yves Cohen é taxativo ao afirmar que o tema do foro interior não foi ignorado pelas Ciências Sociais, em especial no que se relaciona a reflexão sobre o comando e a obediência. (COHEN, 2017, pp. 39-58)

Também os estudos de gênero e feministas, de diferentes vertentes do movimento e lutas, não ignoraram tal questão. Em especial, problematizar como as paixões políticas incidem e são produzidas por corpos que sentem e sofrem com tais paixões e ódios foi e ainda é locus de reflexão e teorização que deve ser cada vez mais estudado e debatido.

É indubitável que uma exigência também de cunho teórico se coloca quando a problematização das paixões, do sentir, do ressentir e da relação dos corpos com o mundo, com o político de forma geral, é posta em perspectiva. Para Márcia Naxara e Stella Breciani, precisamos assumir enquanto historiadores e historiadoras, cientistas sociais, cientistas políticos e filósofos que novos modos de pensar são necessários para que haja concretamente um abandono de antigas verdades e seguranças que são proporcionadas por perspectivas sedimentadas, lugares-comum que não 
abarcam a complexidade e a interdisciplinaridade que o estudo dos sentimentos na política requer. (BRESCIANI; NAXARA, 2004).

Pensar tal complexidade, e mesmo as falsas questões e conclusões que perspectivas datadas e não-reconhecidamente parciais propõem, é uma das tarefas assumidas pela pesquisa feminista acadêmica. A crítica à ideia da objetividade científica per se pelo viés da elaboração de uma reflexão de que a objetividade existe, uma vez que se assume que os saberes são parciais e que a perspectiva parcial é um privilégio dentro da ciência, foi motivo de reflexão, em especial de Donna Haraway (1995). Cabe tal ressalva por ela própria ser um posicionamento político dentro da academia, que assumimos nós mesmas e mesmos, pesquisadoras e pesquisadores, enquanto produtores de saber e perspectivas políticas localizadas de ação sobre o mundo, e, portanto, sobre os sentimentos. É preciso problematizar também qual é a parcialidade e os limites que traçamos com a linguagem e os enquadramentos pelos quais reconhecemos ou não determinadas existências enquanto dignas de luto, luta e, por quê não, dignas de estudo. Ainda que não se possa chegar de forma simples ou rápida a algumas respostas, é necessário que alguns questionamentos estejam presentes no fazer do pesquisador e da pesquisadora, como uma vontade crítica e política que abarca elementos de possibilidade e reconhece os limites que circundam o próprio fazer.

Assim, o uso da discussão de Haraway como porta de entrada para o ensaio que pretendemos tecer aqui é imprescindível pelo fato de Haraway também questionar, com sua reflexão, quais são os critérios de ciência e objetividade que se tende a reconhecer enquanto verdadeiramente científicos e, a partir e concomitante a eles, quais problemas da objetividade e de problematização científica incidem sobre o gênero, a raça, os corpos e, é claro, a própria subjetividade. A longa reflexão de Haraway sobre estes critérios ontológicos da ciência e do conhecimento é de extrema valia pois, como a autora diz: 
Assim, creio que o meu e o "nosso" problema é como ter, simultaneamente, uma explicação da contingência histórica radical sobre todo conhecimento postulado e todos os sujeitos cognoscentes, uma prática crítica de reconhecimento de nossas próprias "tecnologias semióticas" para a construção de sentido, e um compromisso a sério com explicações fiéis de um mundo "real", um mundo que possa ser parcialmente compartilhado e amistoso em relação a projetos terrestres de liberdade finita, abundância material adequada, sofrimento reduzido e felicidade limitada. Harding chama esse desejo necessariamente múltiplo de necessidade de um projeto de ciência sucessora e de insistência pósmoderna na diferença irredutível e na multiplicidade radical dos conhecimentos locais. Todos os componentes do desejo são paradoxais e perigosos, e sua combinação é tanto contraditória quanto necessária. As feministas não precisam de uma doutrina de objetividade que prometa transcendência, uma estória que perca o rastro das mediações justamente quando alguém deve ser responsabilizado por algo, e poder instrumental ilimitado. Não queremos uma teoria de poderes inocentes para representar o mundo, na qual linguagens e corpos submerjam no êxtase da simbiose orgânica. Tampouco queremos teorizar o mundo, e muito menos agir nele, em termos de Sistemas Globais, mas precisamos de uma rede de conexões para a Terra, incluída a capacidade parcial de traduzir conhecimentos entre comunidades muito diferentes - e diferenciadas em termos de poder. Precisamos do poder e das teorias críticas modernas sobre como significados e corpos são construídos, não para negar significados e corpos, mas para viver em significados e corpos que tenham a possibilidade de um futuro. (HARAWAY, 1995, p. 15-16)

Incidem de forma direta e tácita sobre esse desejo político de que os corpos tenham significado, possam sentir e serem reconhecidos enquanto sensíveis, e que tenham ainda a própria possibilidade de um futuro, os estudos mais recentes de teóricas feministas e dos estudos de gênero, como Judith Butler, Eleni Varikas, Hasana Sharp, Chloë Taylor, bell hooks além da própria Donna Haraway e da crítica cultural, para citar alguns nomes. Muitas pesquisadoras feministas e queer estão se dedicando a formas de pensar que não sejam fundamentadas e reprodutoras do humanismo iluminista e do discurso liberal. (SHARP; TAYLOR, 2016, p. xiv). A partir de diferentes entradas e escopos específicos de problematização, tais pesquisadoras têm semelhante comprometimento em questionar e 
fomentar a criação de outras teorias e exercícios de (des)construção do saber e da linguagem que questionem os próprios parâmetros pelos quais a cultura ocidental e o saber acadêmico foram por muito tempo construídos: a partir de um enquadramento epistemológico calcado em um saber majoritariamente branco, ocidental, reprodutor do binarismo sexual e heteronormativo da prevalência do masculino, fundado e defensor do ideal iluminista de um sujeito que é cartesiano e normal quando produto da razão emancipatória kantiana.

Esse desejo de um sujeito (masculino) cartesiano e iluminista, erigido sob um ideal que opõem e estabelece uma divisão inexistente entre os sentimentos e a razão, entre a ciência e a tradição, e entre o masculino e o feminino diz respeito também, segundo Sharp e Taylor, a uma crítica ontológica sobre a própria vida, e sobre a possibilidade de se pensar em filosofias feministas sobre a vida como saída criativa a tais impasses dualistas. (SHARP; TAYLOR, 2016, p. xi). Para Sharp e Taylor, algo mudou dentro dos estudos feministas com a virada para o século XXI, e este algo diz respeito justamente ao questionamento de matriz ontológica sobre a vida, mas também aos questionamentos sobre os quais e pelos quais conseguimos reconhecer sentimentos e vidas - não só humanas - enquanto precárias e dignas de serem vividas.

É notório, a partir da bibliografia mobilizada aqui, que a crítica teórica feminista acadêmica compartilha um mesmo incômodo. Ele diz respeito à contestação e ao desejo de reformulação de ontologias, seja pelo questionamento delas próprias - como o que é vida, morte, ciência, conhecimento -, seja pela advertência da necessidade de se questionar quais formas políticas específicas sustentam e são sustentadas, em uma relação dialógica, por tais concepções ontológicas. É o que faz Judith Butler ao afirmar que a ideia de "vida" é estritamente relacionada ao que uma normatividade política deseja afirmar enquanto tal, negando a apreensão de "vida" para outros seres que não são reconhecidos com os mesmos 
direitos e distinções políticas. Portanto, há existências não reconhecidas enquanto vidas às quais a ontologia não pode ser assegurada. (BUTLER, 2015. p.22).

Butler em suas reflexões pós-11 de setembro nos Estados Unidos, ${ }^{79}$ seguiu uma perspectiva de análise diversa, mas não desconexa dos estudos de gênero: uma preocupação ética, voltada ao questionamento ontológico sobre a vida e as não-vidas, sobre ser ou não ser enlutável, isto é, digno de ter sua morte sofrida e respeitada, após ter sido evitada a qualquer custo.

Tal qual Sharp e Taylor, Butler, em seus estudos produzidos com mais fôlego a partir dos anos 2000, passou a refletir com mais atenção sobre as possibilidades de se apreender uma vida, e sobre a necessidade filosóficopolítica em tempos de guerra, e "em nome da democracia", de se reconhecer através da comoção a vulnerabilidade, a dor, a precariedade, o direito à proteção e à prosperidade, enfim: um pensamento pautado na interdependência de todos os seres vivos como a única forma de linguagem capaz de criar uma ética de pertencimento social que seja capaz de romper com lógicas de exclusão, fronteira, raça, gênero, sexo, classe, identidade e "morte justa" que tornam algumas vidas, não-vidas. (BUTLER, 2015, p.15) A seguir, trataremos com mais fôlego e atenção a este respeito.

\footnotetext{
79 Utilizamos aqui da diferenciação temporal e temática dos estudos de Butler feita por uma pesquisadora que se dedicou a pensar o conjunto da trajetória e das produções da filósofa. Schippers refere-se a textos de Butler, como Gender Trouble: Feminism and the Subversion of Identity (1990), como os primeiros textos da autora, ou antes do 11 de setembro (9/11). Como os estudos de Butler tomaram um caminho em partes diverso às reflexões sobre a performatividade (mas não antagônico a esta perspectiva ou aos estudos de gênero) após o atentado contra as Torres Gêmeas, Schippers coloca este acontecimento como referência temporal para datação metodológica em sua análise. Assim, obras como Precarious Life: powers of violence and mourning (2004), e Quadros de Guerra: quando a vida é passível de luto? (2009), são dois exemplos destes trabalhos pensados como reflexão e reação às violências perpetradas pelos Estados Unidos da América em nações islâmicas, ou mesmo contra seus cidadãos de origem árabe ou muçulmanos. Como a questão do $9 / 11$ é recorrente e essencial dentro da reflexão de Butler a respeito dos enquadramentos pelos quais se reconhecem ou não vidas, e sobre as possibilidades que temos de criação de laços afetivos não-segregacionistas em tempos de guerra, acompanhamos a observação de Schippers a respeito da demarcação cronológica dentro da produção acadêmica da filósofa (SCHIPPERS, 2014).
} 


\section{Molduras da exclusão: o que é uma vida digna pela qual se comover?}

Os estudos dedicados a pensar os sentimentos na política têm uma concordância e diálogo bastante significativos sobre os estudos feministas e de gênero, qual seja, a de que ambos atuam na denúncia da hierarquização e da disjunção completa entre razão e emoção sustentada por filosofias iluministas e positivistas. Intelectuais feministas de diversos campos fazem parte de um esforço, já de há algumas décadas de pesquisa, que compreende o dualismo cartesiano e a teoria política liberal dominantes, além da ênfase no autocontrole racional, como argumentos de legitimação da exclusão e subjugação do feminino, do efeminado, de toda pessoa, ser ou "coisa" que possa ser rotulada como tal, incluindo nisto a natureza e os sentimentos.

Como se pode compreender, tanto para os estudiosos dos sentimentos na história, quanto para as pesquisadoras feministas dos estudos de gênero e queer, existe uma concordância de que o esforço epistemológico de tais pesquisas deve ser o de reconhecer o Homem Iluminista como um projeto utópico historicamente vencedor, mas não o único projeto e/ou possibilidade de existência dos indivíduos. (SHARP; TAYLOR, 2016, p. xiv) Reconhecer que ele foi um paradigma que guiou diversas correntes filosóficas e das ciências humanas nos últimos séculos permite trazer ao campo de reflexão que tudo que a ele se relaciona - como, por exemplo, a superioridade da razão em detrimento dos sentimentos, e mesmo o ideal do sexo masculino enquanto aquele que é o ser racional e capaz do exercício de racionalizar - foi um modelo desejado, eleito por interesses políticos e relações de poder, que criou paradigmas e enquadramentos de compreensão do mundo que podem ser modificados, uma vez que são historicamente datáveis.

Como discorre Ladelle McWhorter, isso não quer dizer que a teoria feminista acadêmica exista para destruir o projeto iluminista e toda corrente de interpretação sobre o mundo que sorve de suas considerações. É, antes de tudo, uma defesa de que a nossa própria forma de existir e conceber o mundo pode e deve ser posta em crítica em favor de que outras formas de existir e de se relacionar, não-binárias, marginalizadas, e do hemisfério sul, por exemplo, possam expor suas perspectivas sobre a vida, sobre a 
filosofia, sobre a filosofia política e sobre os modos de sentir. (SHARP; TAYLOR, 2016, p. xiv)

Através do reconhecimento de que a problematização dos discursos e das relações de poder que ele implica colocam qualquer verdade ou figura universal em suspenso, Judith Butler vincula-se a esta crítica que faz uma recusa a perspectivas que sejam meta-narrativas, como a recusa da aceitação da existência de sujeitos universais e da macro-consciência racionalista. Essa introdução é necessária, uma vez que em seu livro, Quadros de Guerra: quando a vida é passível de luto? (2009), é notório que a defesa de Butler de que o que nos une a todos é nossa condição de precariedade, é uma argumentação que tem dois caminhos simultâneos. Por um lado, é uma defesa e uma via de ação política e ética para se lutar contra os impasses da exacerbação da violência e da guerra no mundo. Por outro, o reconhecimento da precariedade dos seres vivos, incluindo os que não são humanos, age como uma denúncia da insustentabilidade da perspectiva de que o sujeito iluminista, o racional e o humanismo, ele próprio diga respeito à defesa e à sustentação da dignidade e dos sentimentos de todas e todos os seres humanos e vivos.

Para Pierre Ansart, as emoções, os sentimentos e as paixões estão presentes e são parte da experiência cotidiana, das relações, instituições e movimentos. As Ciências Sociais e Políticas devem produzir reflexões sobre os fatos relativos às sensibilidades políticas que não sejam esforços de explicação e racionalização, eles próprios negligentes, com o potencial de comoção e interpretação intrínsecos a si mesmos que a dimensão afetiva e passional tem na vida e nas ações dos indivíduos. (ANSART, 2001, p. 146). Butler, ao fazer a defesa de uma crítica do direito à vida, reconhece que o ódio, a ira, as paixões políticas e a nossa própria capacidade de sentir comoção frente a dor ou ao amor de outrem é parte da discussão ética na sociedade contemporânea. ${ }^{80}$ Alguns tipos de destruição são eticamente relevantes, enquanto outros não, e as condições de vida e de reconhecimento do luto, da perda, da ausência, da falta, enfim, do sentir, são condições predominantemente sociais - e privilégios políticos, raciais, religiosos e identitários. (BUTLER, 2015, p. 33-38).

Assim, a perspectiva de Butler - a de que nós vemos o mundo e aquilo que nos sensibilizamos a partir de molduras politicamente concebidas pelas

\footnotetext{
${ }^{80}$ Afirmamos aqui que Butler refere-se a tais questões para a sociedade contemporânea porque a filósofa dedicase a pensar a situação das guerras pós-11 de setembro, e os enquadramentos de reconhecimento da vida a partir de exemplos norte-americanos em relação ao mundo árabe/muçulmano. Isso não é dizer que a reflexão se restrinja a esta temporalidade, ou só caiba para tal, mas, sim, manter a referência de pensamento de Butler.
} 
quais apreendemos algumas vidas como dignas de serem cuidadas, enlutadas, reconhecidas enquanto vidas enquanto outras não são - é uma forma de problematizar o campo de poder político que a dimensão afetiva tem. Tais molduras ou enquadramentos são os mesmos pelos quais não conseguimos apreender algumas outras vidas como perdidas ou lesadas, ou passíveis de serem perdidas ou lesadas, em prol da manutenção da segurança da nossa própria vida. (BUTLER, 2015, p. 14)

Existem, portanto, escopos parciais e normas que constroem a própria condição de ser reconhecido em todas as sociedades e culturas. O desafio está, nas palavras da autora, "em saber como essas normas operam para tornar certos sujeitos pessoas 'reconhecíveis' e tornar outros decididamente mais difíceis de reconhecer." (BUTLER, 2015, p. 20). É por isso que, para Butler, não são todas as vidas que são enlutáveis: há vidas humanas e não-humanas pelas quais não nos comovemos ao ponto de reconhecermos que elas não podem ser mortas; não reconhecendo-as enquanto vidas, apesar da matéria do corpo ser viva, não são vidas pelas quais a morte será lamentada.

Pierre Ansart defende que uma Ciência Social das paixões sociais e políticas deve se preocupar em procurar os rastros, os "sinais" das emoções e das "expressões que são os apelos, os manifestos, os discursos, as proclamações políticas, mas também os discursos ambíguos, cuja intenção não é propriamente política." (ANSART, 2001, p. 153) A reflexão de Butler em torno da morte, do luto e da comoção ou não dialoga com isto que "parece" não ser propriamente político.

A partir dessa reflexão, não é errôneo afirmar, portanto, que nossa sensibilidade afetiva, nossa capacidade de sentir inclusive o luto de seres vivos, é ela própria política e socialmente concebida. Do ponto de vista da teoria da história e da reflexão historiográfica, é uma perspectiva que sustenta a historicidade dos sentimentos e do sentir e sua relação com o poder, debate de longa corrente de discussões, como aquela à qual Ansart e Cohen são aqui mobilizados enquanto representativos.

O que de novo e atual tal perspectiva de Butler oferece para análises historiográficas é que tais molduras estão também politicamente saturadas e de que o que está em jogo são as condições que tornam a vida sustentável, ou então, se as condições de vida podem ser melhoradas para que as condições precárias sejam amenizadas. (BUTLER, 2015, p.57)

Como já indicamos anteriormente, os estudos de Butler pós-11 de setembro são aqueles com os quais refletimos neste estudo por serem os que têm 
uma abertura mais significativa para a discussão em torno da comoção e de quando e quais vidas são passíveis de luto. Tal denúncia e reflexão já existiam em Gender Trouble - Feminism and the Subversion of Identity (1990), se considerarmos que ali o esforço de Butler é o de apresentar a forma retórica e performática pela qual a sexualidade e o gênero são inscritos nos corpos - e denunciar o não-reconhecimento social e as violências física, psicológica e simbólica constante às quais aqueles e aquelas que não se identificam com os binarismos sexuais e de gênero são submetidos. Ao desnaturalizar o gênero e sua inscrição dos gêneros aos corpos, Butler relaciona tal esforço ao desejo linguístico e político de tornar todas as formas de vida "vivíveis". (BUTLER, 1990, p. xX)

Desta forma, há mais essa aproximação bastante significativa entre os estudos de gênero e feministas e a denúncia da necessidade de se pensar a questão da violência, da ética e dos sentimentos na política enquanto estruturantes das relações sociais, culturais e dos próprios corpos humanos. Em um trabalho intitulado Violence, Mourning, Politics (BUTLER, 2003), anterior a Quadros de Guerra (que tem a primeira publicação em inglês datada de 2009, e a primeira em língua portuguesa no Brasil em 2015), Butler já afirmava categoricamente que o que vinha incomodando e preocupando a ela, à luz da violência global, era quem contava como humano, quais vidas humanas contavam como vidas, e quais delas seriam enlutáveis.

Nesse estudo, Butler já expressa sua defesa, que aparece com maior fôlego e argumentação no seu livro, de que ela se preocupa em pensar se podemos identificar algo que seja um "nós", a despeito de nossas diferenças de localização e história. Para Butler, a eminência da perda da vida é o que pode nos identificar enquanto um coletivo.

Não cabe aqui discutir com maior fôlego quem é esse "nós" ao qual Butler se refere, mas é necessário dizer que a autora não argumenta com esta imagem de um coletivo de maneira vazia, ou então que acione um novo ontológico. Em Quadros de Guerra, ela faz com maior fôlego essa discussão sobre quem estaria incluído neste "nós", e por qual "nós" somos, afinal, responsáveis. O que é necessário frisar é que Butler defende que a ideia da similitude e da identificação pela semelhança pré-fabricada (nacionalidade, grupo étnico, enfim) não pode servir como elo de reconhecimento, pois eles próprios são limites de responsabilidade e de ordem política que regula tais reconhecimentos. Butler também afirma que não podemos tomar este "nós" enquanto aqueles democráticos, pois a democracia enquanto um projeto missionário é um erro. É por isso que, 
para a autora, a pergunta deve se manter em aberto e fomentar discussões, pois "temos diante de nós o desafio de repensar e reformular uma concepção da responsabilidade global que faça frente a essa apropriação imperialista e sua política de imposição." (BUTLER, 2015, p. 60-64)

Deriva daí o entendimento de Butler de que a necessidade de reconhecimento e de que nossas chances de sobrevivência estão diretamente relacionadas a um abandono do individualismo e uma cisão da ideia de sujeito nacional em favor da tessitura de laços de sociabilidade, interdependência e comoção que reconheçam todas as vidas humanas enquanto vidas dignas de serem enlutadas (BUTLER, 2015, p. 78). Isso significa, de acordo com a filósofa, que cada um de nós é constituído politicamente em virtude do desejo, e também em virtude da vulnerabilidade social dos nossos corpos e do luto. Perda e vulnerabilidade parecem mesmo seguir à constituição social de nossos corpos, relacionais a outros, expostos a outros e vivendo o comum risco da finitude em virtude de tais exposições. (BUTLER, 2003, p.10.)

Todos nós, em algum momento, já vivemos ou viveremos a eminência e o momento da perda de alguém que amamos, já lutamos e amamos para evitar a perda - e é por tal inexorabilidade da perda que, para Butler, ela é aquilo que nos une, a única coisa comum a todos. Butler, nesse estudo, também oferece uma reflexão específica sobre o sentimento do luto, e como lidar com esta comoção que é de extrema valia, pois não deixa de ser um manifesto para que nossa relação com esta comoção específica seja modificada: para que novos modos de pensar, também de dentro da teoria acadêmica - feminista ou não - tomem como mister o esforço para que nossos enquadramentos pelos quais lidamos com o luto e a morte sejam modificados. Segundo a autora,

Muitas pessoas pensam que o luto é uma situação de privação que nos devolve para uma situação solitária e é, nesse sentido, despolitizante. Mas eu acho que fornece um senso de comunidade política de uma complexa ordem, e faz isso em primeiro lugar trazendo à tona os laços relacionais que têm implicações para a teorização de dependência e responsabilidade ética. Se meu destino não é originalmente ou finalmente separável do seu, então o "nós" é atravessado por uma relacionalidade com a qual não podemos argumentar 
facilmente; ou melhor, nós podemos argumentar contra isso, mas estaríamos negando algo fundamental sobre as condições sociais de nossa própria formação. (BUTLER, 2003, p.12). [Tradução minha]

Assim, entendemos que repensar a forma como nos permitimos sentir o luto - reconhecidamente um sentimento político -, os campos de exclusão ou inclusão afetiva, os enquadramentos e quais corpos eles contemplam dentro destes campos de comoção é um caminho teórico e metodológico para colaborar enquanto perspectivas de análise para uma ciência social e histórica das paixões sociais e políticas.

Como apresentado no começo deste trabalho, o objetivo deste ensaio foi pensar quais colaborações uma parte da crítica teórica feminista acadêmica e dos estudos de gênero podem trazer para o estudo dos sentimentos na política. Em coerência a tal objetivo, é necessário fazer uma consideração que pode ser bem articulada com esse ponto da análise de Butler sobre o luto e as vidas precárias demais para serem veladas quando mortas.

Butler não está sozinha nesta denúncia de que escopos parciais constroem condições de ser reconhecido. Em Quadros de Guerra, sua argumentação sobre o luto toma um aspecto mais amplo do que este acionado anteriormente com a citação literal do texto. Nele, a autora segue uma linha de argumentação sobre a capacidade de sobrevivência, a vulnerabilidade e a comoção serem desiguais ao redor do mundo. A distribuição desigual do luto público é, para Butler, uma questão de extrema importância. É este luto público que cria ícones, que legitima o dever de memória e também que legitima guerras, como o caso do discurso de George W. Bush após um mês do atentado às Torres Gêmeas, em que ele disse que, passado o luto, era o momento da ação - ou seja, a comoção do luto transmutada em uma comoção para o não-luto à vidas perdidas numa guerra em outro lugar do mundo. O reenquadramento do significado do luto para o ódio e a ira foi o gatilho final para a ação de ocupação do Iraque por tropas norteamericanas. (BUTLER, 2015, p. 65-66).

Uma importante contribuição teórica e que defende novas perspectivas e paradigmas de interpretação sobre o mundo está apresentada aqui, e ela é bastante sensível também a outras vertentes da crítica feminista e dos estudos de gênero. Em Butler, seu apelo à interdependência é também um apelo a uma ética da não-violência: 
Não se trata de opor à capacidade de destruição per se, de contrapor esse sujeito cindido do nacionalismo norteamericano a um sujeito cuja psiquê quer sempre e unicamente a paz. Admito que a agressão faça parte da vida e, consequentemente, também da política. A agressão, porém, pode e deve estar separada da violência (sendo a violência uma das formas que a agressão assume), e existem maneiras de dar forma à agressão que atuam a serviço da vida democrática, incluindo o "antagonismo" e o conflito discursivo, as greves, a desobediência civil e mesmo a revolução (...) Pode-se concluir, ademais, que a única alternativa é encontrar meios de elaborar e controlar a capacidade de destruição, dando-lhe uma forma vivível, o que seria uma maneira de afirmar sua existência permanente e assumir a responsabilidade pelas formas sociais $\mathrm{e}$ políticas por meio das quais ela se manifesta. (BUTLER, 2015, pp. 78-79)

Butler tem uma filiação filosófica e política que defende elaborações éticas de não-violência, incidindo, portanto, na defesa de subjetividades nãoviolentas como saída prática e política ao impasse da vulnerabilidade dos corpos e das interdependências subjetivas e sensíveis.Todavia, a violência, a capacidade de destruição em massa e a incapacidade de sentir comoção, bem como o lugar do corpo nesta cosmologia de poderes, não dizem respeito unicamente a vidas humanas, e neste ponto uma linha da crítica teórica feminista pode ter ainda muito caminho para dialogar com os estudos das paixões sociais e políticas. Referimo-nos a uma linha teórica que pensa em filosofias feministas sobre a vida, já citadas neste ensaio de forma breve e com a qual desejo fazer uma derradeira reflexão.

Que Butler afirma que a vulnerabilidade dos corpos (e com isso a comoção) é distribuída de maneira desigual no mundo, e que nosso dever (também enquanto pesquisadores das ciências humanas) para com as gerações futuras reside em criar subjetividades e subjetivações que trabalhem com um esforço ético e político para banir a vulnerabilidade criando subjetividades comovidas e comoventes (2003, p.18.), esta é uma afirmação política e teórica até que facilmente partilhável com demais pesquisadores e pesquisadoras, mesmo que não sejam filiados aos estudos 
de gênero e feministas. Porém, é uma perspectiva extremamente parcial e ainda localizada em um saber centrado no humanismo iluminista tomar como único objeto deste esforço ético seres humanos.

Quando reconheceremos teórica e epistemologicamente que as figuras do pária e o campo político não são só compostas pelas mais variadas formas (e injustiças) de figuras humanas?

Hasana Sharp e Clhoë Taylor entendem que outros animais, tal qual os humanos, nascem em corpos e num mundo onde eles são dependentes e vulneráveis a outros em virtude de serem justamente seres com corpos. Para as duas autoras, parece possível que os argumentos éticos e políticos de Butler, que constroem esta noção de vulnerabilidade corporal, possam ser estendidos a outras espécies de seres vivos que não só os seres humanos, uma vez que vivemos em uma sociedade e um mundo em que alguns animas e algumas partes da natureza são reconhecidas enquanto defensáveis e dignas de luto, a despeito de outras. (SHARP; TAYLOR, 2016, p.11). Usualmente, consideramos que a exclusão afetiva pode ser problematizada, mas temos uma visão paradigmática de que tais exclusões afetivas, produtoras da condição de pária, são relacionadas unicamente a grupos humanos de minoridade política. Sharp e Taylor, ao questionarem se nossa própria reformulação da linguagem não pode ir a favor de uma teoria que considere a vulnerabilidade política e sensível dos corpos capaz de abarcar o reconhecimento de tais preceitos éticos também para os animais e a natureza em uma acepção mais ampla - ou seja, todos os seres vivos -, colaboram em questionar se nossos (aparentes) novos caminhos não são eles próprios novas ontologias exclusivas e excludentes, que deixam de contemplar vidas às quais a própria "nova" ontologia não pode ser assegurada. Esta é uma linha de reflexão de extrema valia e importância que precisa ser mais problematizada e tomada como objeto de discussão e debate nos círculos acadêmicos brasileiros.

\section{REFERÊNCIAS}

ANSART, P.. Em Defesa de Uma Ciência Social das Paixões Políticas. In: História: Questões \& Debates, Curitiba, n. 33, p. 145-162, 2001. Editora da UFPR.

BRESCIANI, S. M. et al. Memória e (res) sentimento: indagações sobre uma questão sensível. 2. ed. Editora UNICAMP., 2004.

BUTLER, J.. Gender Trouble - Feminism and the Subversion of Identity. New York: Roudledge, 1990.

BUTLER, J.. Quadros de guerra: quando a vida é passível de luto. Trad. S. T. M. Lamarão \& A. M. Cunha. Rio de Janeiro: Civilização Brasileira, 2015.

BUTLER, J.. Violence, mourning, politics. In: Studies in Gender and Sexuality, Local?, v. 4, n. 1, p. 9-37, 2003. 
COHEN, Y.. O foro interior, a obediência e as Ciências Sociais: uma história entre indústria e política na França e na União Soviética (1928-1938). In: BREPOHL, M.; BOSCHILIA, R. (Dir.). Obediência, autoritarismo e foro interior. Curitiba: Editora UFPR, 2017, p. 39-58.

DAVIS, A.. Mulheres, raça e classe. Trad. Heci Regina Candiani. São Paulo: Boitempo Editorial, 2016.

HARAWAY, D.. Saberes localizados: a questão da ciência para o feminismo e o privilégio da perspectiva parcial. In: Cadernos Pagu, Local, n. 5, p. 7-41, 1995.

HOOKS, B.. A'int I a Woman: Black Women and Feminism. Local: Routleged, 2016

SCHIPPERS, B.. The political philosophy of Judith Butler. Local: Routledge, 2014.

SHARP, H.; TAYLOR, C. (Ed.). Feminist Philosophies of Life. Local: McGill-Queen's Press-MQUP, 2016. 


\section{AS ELEIÇÕES IMPERIAIS: O TEATRO DAS ELEIÇÕES EM SÃO JOSÉ DOS PINHAIS NA SEGUNDA METADE DO SÉCULO XIX}

Gladisson Silva da Costa 81

Resumo: Em meados do século XIX, São José dos Pinhais ainda era uma região bastante empobrecida, voltada à agricultura e com um número reduzido de escravos. Entretanto, o comércio ervateiro Ihe conferiu alguma expressão política e econômica. Para recuperar aspectos da "fisionomia" social dessa localidade, buscou-se construir uma espécie de mapa socioeconômico do município, permitindo a análise de alguns aspectos socioeconômicos e sua correlação com a divisão administrativa de São José dos Pinhais. Com base nos dados extraídos da lista de qualificação de votantes de 1878, construiu-se uma espécie de "topografia social" dessa vila paranaense, possibilitando uma melhor compreensão das tramas existentes no interior da elite são-joseense de meados do século XIX, bem como das suas estratégias para manter sua posição social. Desta forma, este trabalho, ao se debruçar sobre uma sociedade empobrecida, mas, nem por isso, menos hierarquizada, pode contribuir sobremaneira para as análises acerca do papel do teatro das eleições para aqueles que exerciam o poder local no Brasil Império.

Palavras-chave: Eleições. Brasil Império. Coronelismo. Hierarquia.

${ }^{81}$ Currículo Lattes: http://lattes.cnpq.br/5205746487144032. 


\section{Introdução}

A historiografia pertinente concorda, ao menos minimamente, que o tropeirismo foi a principal atividade da Comarca de Curitiba durante todo o século XVIII e primeira metade do XIX. Tanto que o crescimento desta atividade acabou por criar as condições objetivas para a emancipação da Comarca em 1853, exatamente na época em que o tropeirismo alcançava seu apogeu (COLNAGHI, 1992).

Dessa forma, durante a primeira metade do século XIX pode-se notar a coexistência de duas atividades econômicas de grande vulto na região do atual Paraná: o tropeirismo, devido às possibilidades oferecidas com o comércio com a região sudeste e a produção do mate para exportação, estimulada pelo comércio com o Prata.

Desde meados do século XVII, já se registrava a extração e a venda da erva-mate na região da Freguesia de São José dos Pinhais, visto que os ervais cobriam milhares de quilômetros quadrados desse termo. Todavia, cabe ressaltar que, devido ao seu caráter extrativista,

[...] a economia do mate localizou-se onde os ervais nativos eram mais abundantes, densos e produtivos, a saber, nas matas do alto Iguaçu e do rio Negro, das quais parte significativa pertencia à, então, freguesia de São José dos Pinhais. (SBRAVATI, 1980).

Dessa forma, o comércio ervateiro conferiu a São José alguma expressão na nova economia dinâmica. Foi nesse contexto, aliás, que, pela Lei Provincial no 10, de 16 de julho de 1852, a freguesia de São José dos Pinhais foi elevada à categoria de vila, sendo criado o município, cuja instalação oficial se deu em 8 de janeiro de 1853. 
Entretanto, apesar do relativo crescimento da região, Luiz Adriano Borges destaca que São José dos Pinhais era uma região bastante empobrecida, voltada à agricultura e com um número reduzido de escravos. Segundo o autor, nem a coleta da erva-mate (principal atividade econômica da Província em meados do século XIX), nem a agricultura (amplamente difundida entre os habitantes desta vila), fizeram de São José uma vila economicamente forte (BORGES, 2009). Assim, tendo em vista esse alerta, este trabalho apresenta um estudo das relações perpetradas pela elite local que, apesar de singela quando comparada àquelas existentes nas poderosas vilas do Império, certamente exercia um grande poder de mando em sua localidade.

Tomando o aumento populacional como um possível indicativo do crescimento e dinamização da economia de uma região, faz-se importante citar alguns dados produzidos a partir de estatísticas da época, os quais foram apresentados por Cacilda Machado. De acordo com tais informações, entre 1782 e 1830 a população livre da então freguesia de São José dos Pinhais já havia crescido cerca de $278 \%$, superando, inclusive, a taxa de crescimento da própria vila de Curitiba, a futura capital da Província do Paraná, que atingira no mesmo período um percentual de cerca de $191,5 \%$ (MACHADO, 2006).

Por outro lado, paralelamente ao considerável aumento populacional, conforme a autora, vislumbra-se que ao longo de todo o século XVIII e primeiro quarto do XIX ocorrera uma considerável diminuição no seleto grupo dos que "podiam ter escravos" nesta modesta localidade. Como indicativo de tal fato, sabe-se que no ano de 1765 não havia escravos em $79 \%$ dos domicílios da freguesia de São José, índice que chega a $83,6 \%$ em 1827 (MACHADO, 2006). 
Como demonstrado em trabalho de conclusão de curso, ${ }^{82}$ este quadro não deve ser entendido como uma atenuação das divisões sociais no interior da sociedade são-joseense, visto que outras formas de hierarquização social, que não apenas a posse de escravos, foram amplamente utilizadas para manter o status quo da elite local. Dentre as quais, podemos sublinhar as práticas de ampliação das redes de dependência dos potentados locais através da cooptação de agregados, por exemplo (COSTA, 2008).

Dessa forma, em áreas e/ou períodos em que os escravos formassem um grupo com pouca representatividade percentual (como acreditamos ser o caso de São José dos Pinhais na segunda metade do século XIX), a hierarquização dos livres se operaria de maneira ainda mais marcante, seja através da confecção de redes de agregados, seja pela criação de rendas ativas em relação à população pobre da região (LIMA, 2005; MACHADO, 2006).

Corroborando com este viés de análise, o brasilianista Richard Graham, em pesquisa acerca da influência exercida pelo clientelismo sobre a política imperial, especialmente durante o reinado de Pedro II, sublinha que os políticos deste período "gastavam grande energia no incremento de suas redes de dependência, fornecendo ou pedindo favores". Para o autor, a ideia que vigorava no Brasil oitocentista era de que todas as relações sociais consistiam em uma troca de proteção por lealdade. Tal realidade, segundo ele, devia-se à incapacidade do governo central em atender as necessidades da população do Império, "deixando os pobres à própria sorte" (GRAHAM, 1997, p. 41).

Se para os mais pobres essa busca por proteção era uma estratégia eficiente para atenuar as dificuldades da vida, a prática do clientelismo

\footnotetext{
82 Nos quarteirões de São José: um estudo sobre poder e sociedade em São José dos Pinhais na segunda metade do século XIX (1852-1878), 2008.
} 
também se mostrou uma hábil saída para a crescente centralização do poder imperial, visto que o apadrinhamento poderia ajudar a atenuar a intervenção imperial nos interesses das elites locais.

Visando contemplar todas estas questões, o presente trabalho foi dividido em três partes. Na primeira, a partir da análise da ista de qualificação de votantes de 1878, buscou-se apresentar uma visão panorâmica dos quarteirões de São José dos Pinhais em meados do século XIX, na tentativa de construir uma espécie de mapa socioeconômico da região, bem como apontar algumas das estratégias utilizadas pela elite local para exercer seu poder mando e, sobretudo, controlar os mais pobres. $\mathrm{Na}$ segunda, o objetivo foi trazer uma contextualização acerca das eleições imperiais, buscando conectar os meandros das eleições com as disputas por poder e prestígio que ocorriam nas vilas e freguesias do império. Para tanto, além da lista de qualificação de votantes, os dados do Censo de 1872 foram imprescindíveis para melhor compreender a abrangência do sistema eleitoral do período e o grau de envolvimento da população. Tendo em vista que as eleições censitárias parecem ter promovido uma exclusão menor que aquela gerada pela exclusão dos analfabetos do direito ao voto. Com a aprovação da Lei Saraiva (1881), como pretende-se demonstrar mais adiante, essa massa de homens livres, pobres e votantes teve um papel decisivo no "teatro das eleições", sobretudo em uma região depauperada e marcada por uma forte hierarquização dos homens livres, como era o caso de São José dos Pinhais. Por fim, na terceira e última parte, ambiciona-se analisar os conflitos recorrentes perpetrados pelos partidos liberal e conservador no período imperial, tendo em vista as imbricações entre o jogo eleitoral e a manutenção do status quo dos indivíduos naquela sociedade. Desse modo, para ilustrar o alcance de tais questões eleitorais, buscou-se recuperar um evento ocorrido durante as eleições de 1852, em São José dos Pinhais, que envolveu Luzias e Saquaremas e resultou em um tiroteio que deixou, pelo menos, seis mortos em frente à igreja matriz. 
Diante do exposto, apesar do papel periférico de São José, a análise de suas estruturas sociais pode contribuir significativamente para uma melhor compreensão das relações de poder perpetradas na Província do Paraná e, mesmo, na própria sociedade brasileira do século XIX. A importância de um estudo sobre uma vila como São José dos Pinhais, portanto, reside exatamente no fato de que a dinâmica da sociedade sãojoseense do oitocentos estava, possivelmente, bastante próxima da realidade vivida por boa parte das vilas e freguesias do Império do Brasil.

\section{São José dos Pinhais na segunda metade do século XIX: uma visão panorâmica}

Visando construir uma melhor representação da dinâmica dessa região, efetuamos uma apreciação de alguns aspectos socioeconômicos e sua correlação com a divisão administrativa de São José dos Pinhais. Dessa forma, com base nos dados extraídos da lista de qualificação de votantes de 1878 , construiu-se uma espécie de "topografia social" da vila paranaense na segunda metade do século XIX.

No período analisado nesta pesquisa, São José contava com um grande espaço territorial que compreendia as terras hoje pertencentes aos municípios de Araucária, Fazenda Rio Grande, Tijucas do Sul, Agudos do Sul, Piraquara, Mandirituba e Pinhais (MAROCHI , 2003). Além do vasto território, e talvez por causa dele, esta vila caracterizava-se por um notável predomínio do meio rural sobre o urbano. Na freguesia de São José, por exemplo, boa parte dos indivíduos foram qualificados como "lavradores" na lista de qualificação de votantes de 1878. De um universo de 1205 indivíduos presentes na lista, cuja ocupação fora informada, encontramos 1159 lavradores, o que demonstra a grande ruralidade da localidade, bem como aponta para a existência de uma economia fortemente apoiada na 
agricultura de subsistência. Todos os 28 quarteirões da freguesia de São José dos Pinhais apresentaram uma enorme quantidade de lavradores (ver Tabela 1). Alguns deles chegavam a apresentar todos os indivíduos arrolados como lavradores. Dessa forma, São José se mostra como uma vila notadamente rural, onde a agricultura surgia como a principal forma de obter alguma renda, sobretudo aos mais pobres, refletindo talvez a grande disponibilidade de terras cultiváveis existentes na região (COSTA, 2008).

Mesmo no primeiro quarteirão da vila, que abrigava um modesto núcleo urbano, onde existia uma razoável diversidade ocupacional - ao menos para os parâmetros são-joseenses -, a atividade agrícola se fazia presente, uma vez que cerca de $30 \%$ dos indivíduos ali residentes foram recenseados como lavradores. Os dados encontrados por Marcante (2007) para Tibagi, no mesmo período, indicam o tamanho da ruralidade de São José. Segundo ele, a porcentagem de lavradores no núcleo mais urbano de Tibag era inferior a $10 \%$.

TABELA 1 - DISTRIBUIÇÃO DOS INDIVÍDUOS SEGUNDO A PROFISSÃO E QUARTEIRÃO (SÃO JOSÉ dOS PINHAIS, 1878)

\begin{tabular}{|c|c|c|c|c|}
\hline Quarteirões & Lavradores & Negociantes & Outros & Total \\
\hline $1^{\circ}$ Quarteirão da Fachina & 24 & - & - & 24 \\
\hline $2^{\circ}$ Quarteirão da Fachina & 31 & - & - & 33 \\
\hline $1^{0}$ Quarteirão da Vila & 12 & 14 & 13 & 39 \\
\hline $2^{\circ}$ Quarteirão da Vila & 31 & - & - & 31 \\
\hline $3^{\circ}$ Quarteirão da Vila & 29 & - & - & 29 \\
\hline 10 Quarteirão de Cuppy & 46 & 2 & - & 48 \\
\hline $2^{\circ}$ Quarteirão de Cuppy & 54 & 1 & - & 55 \\
\hline $\begin{array}{l}1^{0} \text { Quarteirão } \\
\text { Mandirituba }\end{array}$ & 50 & 1 & - & 51 \\
\hline
\end{tabular}




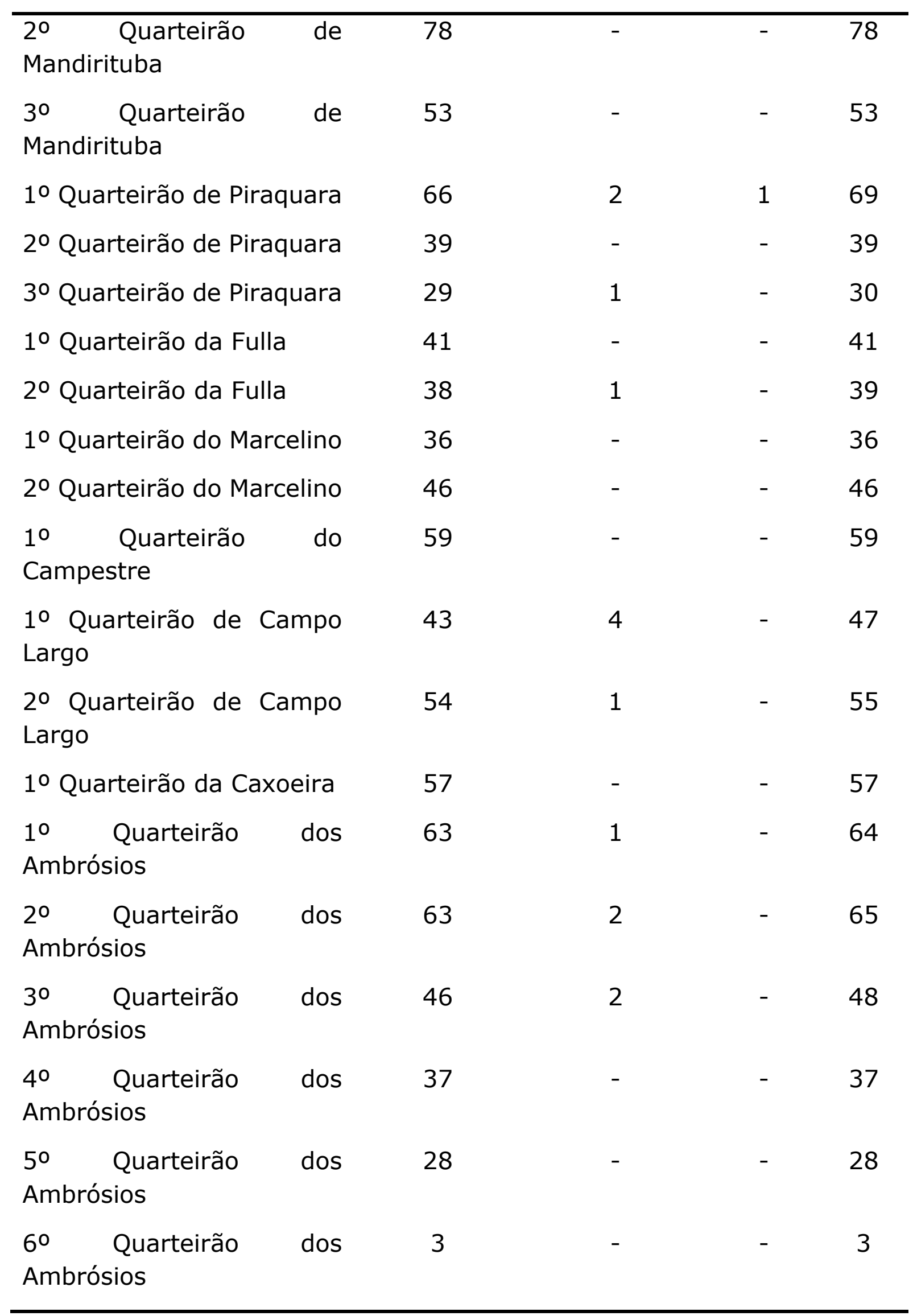




\begin{tabular}{lllllll}
\hline 70 & Quarteirão & dos & 3 & - & - & 3
\end{tabular}
Ambrósios

FONTE: lista de qualificação de votantes de São José dos Pinhais, 1878. (DEAP)

Apesar do predomínio numérico dos lavradores, os dados analisados apontam para um grande domínio econômico dos poucos negociantes presentes em São José dos Pinhais.

\section{GRÁFICO 1 - RENDIMENTOS DE LAVRADORES E NEGOCIANTES EM SÃO JOSÉ DOS PINHAIS (1878)}

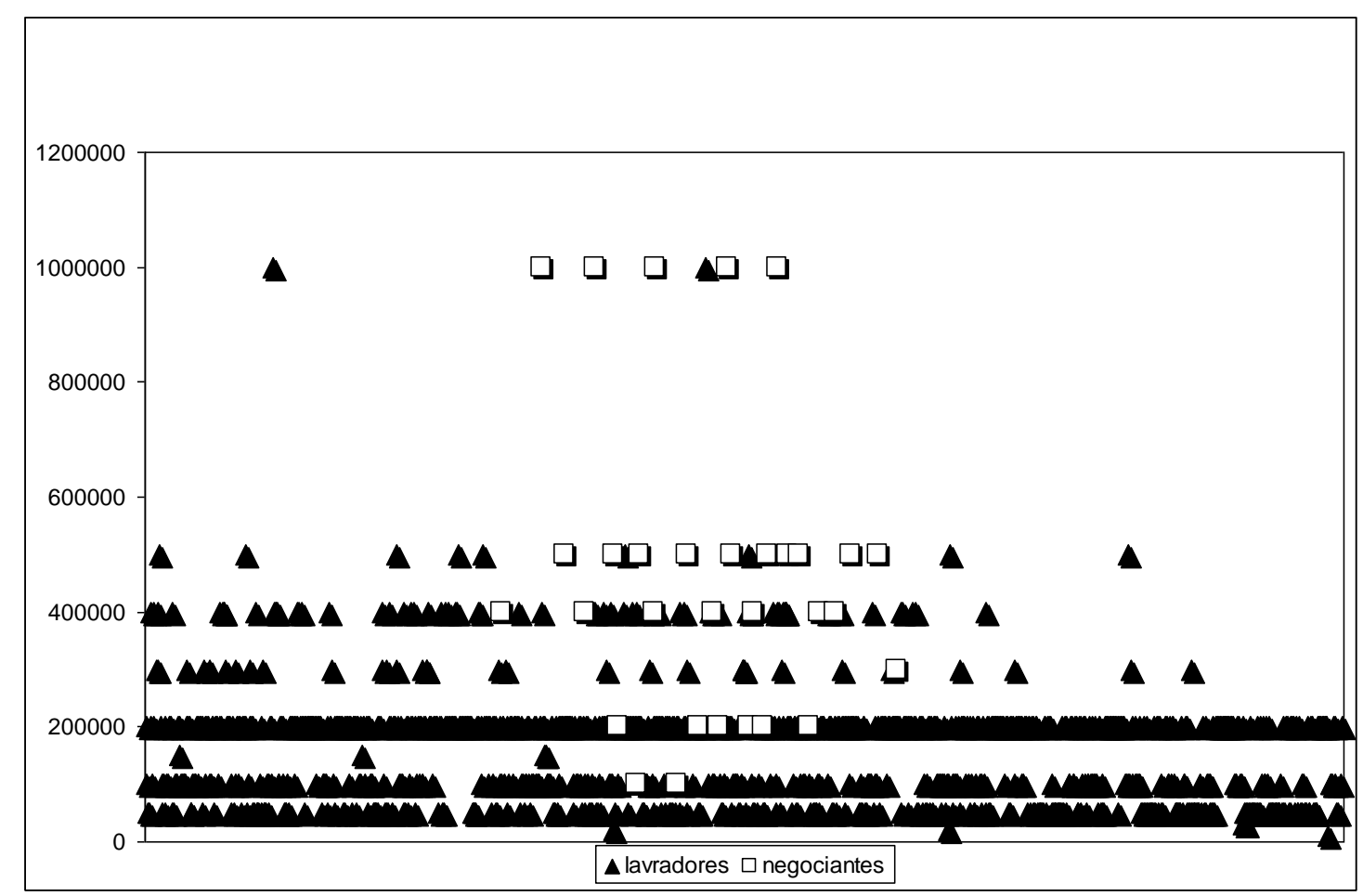

FONTE: lista de qualificação de votantes de São José dos Pinhais, 1878. (DEAP)

Tal realidade, conforme sugere a historiografia dedicada ao tema, indica que a elite de São José dos Pinhais, ao se deparar com a dificuldade 
de adquirir novos cativos (em virtude da escassez de recursos), parece ter despendido grandes energias na busca por novas formas de obtenção de mão de obra. Nesse contexto, a figura do agregado torna-se significativa (LIMA, 2007; CUNHA, 2016; MACHADO, 2006).

Todavia, a formação de redes de dependência através do controle dos mais pobres fornecia outro problema para os potentados locais, a saber, da instabilidade geográfica desses indivíduos depauperados que teriam a sua disposição uma vasta extensão de terras desocupadas para sua fixação. Dessa maneira, acreditamos que a grande redução na disponibilidade de cativos, sobretudo após 1850, tenha levado a pequena elite econômica da localidade, constituída em boa parte por negociantes, a utilizar a usura como um método mais eficaz de manter a população pobre - formada, sobretudo, por pequenos lavradores - sob seu controle (COSTA, 2008; LIMA 2007).

\section{As eleições imperiais: a lista de qualificação e o teatro das eleições}

Para recuperar aspectos da "fisionomia" social de São José dos Pinhais, fez-se necessária a construção de uma espécie de mapa socioeconômico do município. Nessa tarefa, o uso da lista de qualificação de votantes de 1878 como fonte se mostrou bastante produtivo.

Esse documento começou a ser produzido a partir de 1846, quando foram regulamentadas as eleições do Império. Com a implementação da chamada Lei do $\operatorname{Terço}^{83}$ (1875), introduziu-se uma importante inovação no processo eleitoral, visto que se instituiu, pela primeira vez no Brasil, o título

\footnotetext{
${ }^{83}$ A chamada Lei do Terço (1875) foi assim chamada, pois, nas eleições primárias e secundárias, os votantes e eleitores votavam em dois terços do número total dos que deviam ser eleitos. Desta forma, os cargos eletivos no Congresso Nacional seriam preenchidos em 2/3 para a maioria e 1/3 para a minoria.
} 
de eleitor, passando a exigir a ampliação das informações contidas nas listas preparadas durante o processo de alistamento. A partir de então, as listas de qualificação de votantes passaram a registrar os nomes dos qualificados inscritos por ordem alfabética e uma série de informações adicionais, tais como a idade, a profissão, se sabiam ler e escrever, a filiação, o domicílio e a renda conhecida ou presumida (NUNES, 2003; FERREIRA, 2001).

A lista de qualificação, portanto, constitui um excelente ponto de partida para uma caracterização das estruturas sociais de uma dada região. Elas eram elaboradas com o intuito de qualificar os cidadãos ativos, ou seja, aqueles que teriam direito ao voto (simples votante), e os que poderiam ser eleitos (elegível), diferenciando-os, dessa maneira, daqueles que não apresentavam os requisitos mínimos para participar do processo eleitoral do Império, tais como a renda anual de $200 \$ 000$.

Neste ponto, é preciso ressaltar que tal barreira censitária não era difícil de ser superada, mesmo em regiões empobrecias, como São José dos Pinhais, conforme demonstrado adiante. Essa quantia não era algo exorbitante, uma vez que

Uma renda anual de 200 \$ era uma exigência muito modesta na época. Bastam alguns exemplos para demonstrar isso. Dados para o início da década de 1870 referentes à capital do país indicam que uma costureira ganhava $420 \$$, cozinheira e lavadeira, entre $220 \$$ e $420 \$$, e o aluguel de um escravo ficava em $200 \$$. Na mesma cidade, em $1880,87 \%$ votantes da paróquia de Irajá eram trabalhadores rurais, pescadores, artesãos, empregados. Cálculos feitos por Richard Graham com base em dados oficiais de 1870 e 1872 (ano do primeiro censo nacional) indicam que uma média de $50,6 \%$ dos homens adultos livres se qualificava para votar nas 1.157 paróquias do país (CARVALHO, 2011, p. 42).

Segundo a Constituição de 1824 , para se ter direito ao voto, além da exigência de uma renda anual superior a $100 \$ 000$ (ampliada para 
200\$000 a partir de 1846), era necessário atender outros requisitos, tais como: ser cidadão brasileiro ou estrangeiro naturalizado; maior de vinte e cinco anos (ou maiores de vinte e um para os casados e oficiais militares). Desse modo, as mulheres, os escravos e os muito pobres eram excluídos das eleições, bem como os clérigos de ordens sacras e os "filhos-família" que viviam com seus pais (salvo se trabalhassem em ofícios públicos). Tais indivíduos não eram considerados cidadãos ativos pela constituição Imperial, uma vez que não eram capazes de agir sem a tutela de outrem, o que, segundo o pensamento da época, inviabilizava o exercício da cidadania. Essas exigências refletiam a ideia, predominante entre a elite do Império, de que a população (pobre) não possuía condições de entendimento e independência (financeira) para exercer adequadamente a função de votante, o que resultaria na manipulação e no falseamento das eleições. Aliás, essa ideia de que o votante, no Brasil, era uma turba ignorante e dependente se perpetuou e, em 1881, (com a Lei Saraiva) a culpa de toda a corrupção do governo foi inferida ao votante pobre e analfabeto, que fora retirado de cena (CARVALHO, 1996; COSTA, 2008).

Como já informado, além da renda, era preciso ser independente de outros indivíduos para participar das eleições. Dessa forma, a grande maioria dos qualificados (simples votantes e elegíveis), atendendo ao disposto na legislação, deveria ser constituída por homens chefes de fogos, salvo as exceções previstas em lei, ou seja, deveriam ser senhores de si e, se possível, de outros.

Almejando compreender melhor a abrangência desta fonte - a lista de qualificação -, sentimos a necessidade de comparar seus dados com os de outras fontes. Para tanto, buscou-se analisar o Primeiro Censo Geral do Império (de 1872) para lançar luz sobre algumas questões. Como nos informa Lott (2009), o Censo de 1872 foi realizado para subsidiar o esforço imperial que visava à retomada do desenvolvimento econômico no contexto pós-Guerra do Paraguai, e para enfrentar as transformações sociais que se 
vislumbravam, principalmente no que se refere ao movimento abolicionista. Segundo a autora, apesar da notável escassez de meios (humanos e materiais),

\begin{abstract}
10.112.061 habitantes foram recenseados em 1872, em todas as províncias, e a sua distribuição se fez tendo em vista as seguintes variáveis: raça (cor); nacionalidade; sexo, idade, estado conjugal; profissão, alfabetização; domicílio; fogos ou famílias; condição (livre ou escravo); religião; imigração e emigração e naturalização. As características demográficas consideradas pelo censo foram marcadas pela preocupação com a padronização, pois deveriam atender a todas as províncias. Além disso, os aspectos recenseados nos revelam os valores importantes para aquela sociedade. Primeiramente, não são enumerados os habitantes, mas as "almas" de determinada localidade ou freguesia, indicando estreita relação com o universo religioso (LOTT, 2009, p. 193).
\end{abstract}

Nesse sentido, conforme destaca Paul Hugon, apesar de suas imperfeições, o recenseamento "marca um progresso decisivo para um conhecimento demográfico preciso", tornando possível "seguir, com certa exatidão, a evolução da população brasileira, apesar da precisão dos dados não ser absoluta", uma vez que a obrigatoriedade dos registros civis ocorreria apenas com a Proclamação da República (HUGON,1973, p. 39 apud LOTT, 2009, p. 191). Sendo assim, a análise do Censo de 1872 para São José dos Pinhais, devido à sua abrangência, se mostrou bastante produtiva para a presente pesquisa.

Ao analisarmos os dados presentes no documento, vislumbramos que o município estava dividido em outras duas unidades administrativas: uma freguesia homônima (mais populosa) e a freguesia de Nossa Senhora dos Remédios de Iguassú. Cônscios dessa divisão, centramos nossa atenção sobre os dados referentes à freguesia de São José e não do município como um todo, devido à escassez de dados acerca da freguesia de Nossa Senhora dos Remédios de Iguassú. É claro que não pretendemos generalizar os 
dados encontrados para a freguesia, aplicando-os invariavelmente sobre a realidade do município de São José dos Pinhais. Nosso esforço consiste, antes, em utilizar as informações que dispomos sobre essa freguesia para ilustrar a situação da citada vila no contexto da sua emancipação da comarca de Curitiba, em 8 de janeiro de 1853.

Por meio da análise dos dados do Censo (Tabela 2) foi possível identificar, portanto, a presença de 1222 fogos (prováveis votantes) para a freguesia de São José dos Pinhais.

TABELA 2 - POPULAÇÃO LIVRE NO MUNICÍPIO DE SÃO JOSÉ DOS PINHAIS CONFORME O CENSO DE 1872

\begin{tabular}{cccc}
\hline Freguesias & $\begin{array}{c}\text { São José } \\
\text { dos Pinhais }\end{array}$ & $\begin{array}{c}\text { Nossa Senhora dos } \\
\text { Remédios do } \\
\text { Iguassu }\end{array}$ & TOTAL \\
\hline Homens & 3370 & 1545 & 491 \\
Mulheres & 3518 & 1746 & 526 \\
Solteiros & 2366 & 935 & 4 \\
Casados & 910 & 592 & 1 \\
Viúvos & 64 & 18 & 150 \\
Solteiras & 2385 & 1002 & 2 \\
& & & 82 \\
Casadas & 938 & 706 & 7 \\
& & & 164 \\
\hline
\end{tabular}




\begin{tabular}{cccc}
\hline Viúvas & 195 & 38 & 233 \\
Quantidade de & 1222 & 674 & 189 \\
fogos & & & 6 \\
\hline
\end{tabular}

FONTE: Recenseamento Geral do Brasil 1872 - Império do Brasil. (IBGE)

Mesmo admitindo que nem todos estes fogos eram chefiados por homens, visto que o censo informa a existência de 195 viúvas residentes na freguesia, por exemplo, o número de fogos contabilizados em 1872 é bastante próximo aos 1338 indivíduos relacionados na lista de qualificação que analisamos. Contudo, ao excluirmos desse montante os nomes que apresentam as observações "falecido" ou "mudado a anos", por exemplo, chegamos a um número ainda mais parecido com aquele obtido no censo imperial: algo em torno de 1194 indivíduos. Com base nessas comparações, apesar das dificuldades oriundas da distância temporal entre as fontes utilizadas (1872 e 1878), podemos presumir que praticamente todos os fogos (chefiados por homens livres) de São José dos Pinhais, mesmo os mais pobres, foram incluídos na lista de qualificação de 1878, indicando que a cobertura da lista em questão é, realmente, bastante ampla, ao menos quando comparada com outras listas eleitorais do período (COSTA, 2008).

Deve-se levar em conta que tais apontamentos são imprecisos, dentre outros fatores, devido à própria imprecisão inerente a qualquer documento que dependa das informações prestadas pela população, como era o caso das listas de qualificação e do próprio censo imperial. Além disso, as informações presentes na lista eram passíveis de sonegação - seja pelos interesses dos votantes, seja pela preferência política da junta de qualificação (FERNANDES, 2007).

Não obstante tais inexatidões, concordamos com Luiz Adriano Borges que sublinha que "as informações como nome, atividade socioeconômica e renda", presentes na lista de qualificação de votantes de 
São José dos Pinhais, favorecem ao pesquisador a percepção da estrutura social dos votantes desse termo no final do período imperial (BORGES, 2009, p. 18).

Outro ponto que merece ser destacado, diz respeito à ausência de boa parte da população local nessa documentação, uma vez que a legislação vigente negava categoricamente a cidadania a escravos, mulheres e filhosfamília.

Nesse sentido, apesar do processo eleitoral do período imperial, por ser censitário, ter resultado em eleições carentes de ampla participação popular, destacamos a contribuição do artigo de Neila Ferraz Moreira Nunes acerca da questão. A autora lembra que

[...] as análises baseadas em Listas de Qualificação de Votantes têm revelado surpreendentes resultados no que diz respeito aos índices de participação eleitoral em diversas regiões do país, como Curitiba (Cardoso, 1974), Campinas (Magalhães, 1992), São Paulo (Klein, 1995) e Município da Corte (Linhares, 1979), e permitido, simultaneamente, desenhar um perfil mais realista do eleitorado brasileiro no terceiro quarto do século XIX (NUNES, 2008, p. 313).

Richard Graham também fornece uma importante contribuição para a questão do perfil do eleitor no período. Conforme o autor, em todo o Império, " $50,6 \%$ de todos os homens adultos livres, de 21 anos ou mais, independente de raça ou instrução, constavam dos róis de votantes qualificados". No que se refere ao Paraná, o autor calcula, sob os mesmos critérios, uma percentagem de cerca de 40,0\%. (GRAHAM, 1997, p. 147).

Diante do exposto, corroborando com as indicações dos autores citados, acreditamos que a lista de qualificação de São José abarcava 
praticamente todos os homens livres, com 22 anos ou mais, e que eram independentes de outrem. Assim, os eleitores perfaziam notáveis 57,7\% dos arrolados; isso em uma região marcadamente depauperada.

Tais dados sugerem que as eleições à época do Império, não obstante seu caráter bastante excludente, não limitavam o acesso político a um grupo específico de endinheirados, uma vez que vários indivíduos livres, independentemente de sua ocupação, tinham condições reais de alcançar os 200 mil réis exigidos na legislação eleitoral. Nesse sentido, a proibição do voto aos analfabetos, por exemplo, efetuou uma exclusão muito mais drástica que a prática do voto censitário. Entretanto, é preciso destacar que a relativa acessibilidade, como sublinhou Graham (1997), não significava, de maneira alguma, uma política mais democrática, antes, atendia a uma das finalidades do "teatro das eleições", a saber, demarcar publicamente as posições dos atores sociais envolvidos. De modo que as eleições imperiais não poderiam excluir totalmente a "turba ignorante e dependente" do jogo eleitoral, como aquela "ilha de letrados" desejaria, visto que a turba desempenhava um papel particular neste teatro (CARVALHO, 1996).

Seguindo o viés de análise, recorremos à Ivana Stolze Lima, que afirma que as eleições deste período eram uma forma de diferenciação social, em que

[...] os clientes demonstravam lealdade, obediência, reconhecimento; os patrões reafirmavam seu dom de proteção. Por tudo isso o espetáculo devia e podia ser amplo, bem como essencialmente público, quase uma festa, embora uma festa sempre tensa e que podia ser também violenta (LIMA, 1999, p. 185).

As eleições, portanto, eram o palco onde se reproduziam as estratificações daquela sociedade, na qual todos desejavam insistentemente estar acima de outrem e, quando conseguiam, se 
esforçavam para enfatizar (publicamente) o lugar conquistado. Ou seja, o dia da eleição fornecia uma grande oportunidade de lembrar a todos que cada um tem o seu lugar; desde Deus, passando pelo Imperador, até o escravo.

\section{As eleições de 1852 em São José dos Pinhais: matar ou morrer}

A Sociedade do Brasil Império era extremamente hierarquizada. Além dos colonizadores, dos colonos e dos escravizados, havia uma massa de homens livres pobres, vagando pela sociedade sem um lugar fixo a ocupar nessa estrutura e, geralmente, tendo que buscar proteção junto aos potentados locais (NEVES; MACHADO, 1999).

Assim, como a estrutura social caracterizava-se por uma hierarquia de vários níveis, as instituições políticas também refletiam essa ordem, onde o ocupante de cada posição possuía um status particular, que o localizava acima ou abaixo dos outros indivíduos. Evidentemente, a estrutura não estava livre de conflitos, que se davam principalmente através dos partidos que se alinhavam com pontos de vista divergentes (GRAHAM, 1997; CARVALHO, 1996).

Aqui, as recorrentes disputas perpetradas entre Luzias e Saquaremas durante o Império, ganham destaque privilegiado na análise. Conforme a bibliografia especializada, esses partidos apresentavam uma natureza personalista, pois não possuíam um programa específico, e suas principais ações eram quase sempre no sentido de angariar e garantir a lealdade - e o controle - dos indivíduos livres da região.

Nesse sentido, as eleições de 1849, em Curitiba, dão uma amostra dessa disputa. Segundo Oliveira (2002, p. 146 apud BORGES, 2009, p.135), as eleições daquele ano, foram vencidas pelos Liberais, mas prontamente 
anuladas. No ano seguinte, novas eleições foram realizadas e, dessa vez, foram vencidas pelos Conservadores, mas os Liberais denunciaram violências e fraudes no pleito. É nesse contexto que, em 1852, a vila de São José dos Pinhais foi palco de um outro conflito envolvendo Conservadores e Liberais.

Uma das regras não-escritas da política imperial era de que aqueles que estavam no poder

[...] não podiam se dar ao luxo de perder eleições porque a medida de um homem dependia do tamanho de seu grupo de seguidores e uma eleição perdida reduziria visivelmente essa comitiva $[\ldots]$, ser rejeitado por seus próprios seguidores indicava um fracasso de liderança, força, caráter, enfim, da própria clientela (GRAHAM, 1997, p. 112).

Diante desse quadro, portanto, o controle da Junta de Qualificação de Votantes se tornava imprescindível para a manutenção do poder local. A Junta, portanto, era controlada pelo grupo que estava no poder. Ou seja, era esse grupo quem decidiria sobre quem seria ou não qualificado como votante. Raymundo Faoro chama a atenção para o fato de que não havia uma qualificação prévia de votantes, ou seja, aceitavam-se os votos de quem queria e recusavam-se os de grupos rivais, "a pretexto de julgar as exclusões constitucionais à participação do sufrágio" (FAORO, 2001, p. 421). Dessa forma, a lei sobre as exigências de renda (ou quaisquer outras questões de ordem), previstas na legislação imperial, era interpretada de acordo com as necessidades e interesses dos chefes locais que ocupavam o poder no momento.

Refletindo o peso da hierarquia social vigente, cada liderança formava um pequeno exército de agregados, capaz de gerar grande tensão nos dias de eleição nas pequenas vilas e paróquias do Império. As eleições, portanto, "testavam e ostentavam a liderança do chefe local" (GRAHAM, 1997, p. 17). Nesse sentido, segundo nos informa Manoel Rodrigues Ferreira, 
[...] era nos dias de eleição que os adversários se enfrentavam e procuravam ou ganhá-las ou tirar a limpo as suas questiúnculas. As lutas políticas, antes das eleições, obedeciam à certa moderação, quase que se restringiam a discussões no Parlamento. No dia das eleições, entretanto, todo o furor antes reprimido explodia, provocando, entre os partidários, toda a série de desatinos. Tudo se corrompia nesse dia: mesas eleitorais, autoridades, eleitores, etc. 0 objetivo era ganhar de qualquer maneira. E nesses dias de eleições, as paixões políticas se desencadeavam (FERREIRA, 2001, p.168).

O resultado de uma eleição, portanto, era a consequência de uma complicada rede de alianças e compadrios, que eram confeccionadas ao longo de toda uma vida. Nesse contexto, aqueles que contavam com o maior número de apoiadores, venciam, seja pela troca de favores, seja pela violência. Tratase de um período em que era comum que as eleições fossem realizadas dentro das igrejas. Entretanto, nem a sacralidade do imóvel impedia que os ódios explodissem durante o pleito.

Nas eleições secundárias, de 07 de novembro 1852, por exemplo, após a tão esperada elevação de São José dos Pinhais à categoria de vila, as querelas entre Luzias e Saquaremas se misturaram às desavenças e interesses locais e resultaram em um tiroteio em frente à igreja matriz, que levou à morte de, pelo menos, seis pessoas e deixou cerca de vinte feridos. Entre os mortos estavam: Antônio Franco, pardo liberto; Manoel Alves Pereira (Juiz de Paz e o vereador mais votado); Custodio Teixeira da Cruz; Mathias Pereira do Vale; Matheus Jose, pardo; e o cadete Benjamin Pereira de Vasconcelos (BORGES, 2009; MAROCHI, 2003).

Conforme relatos do período, a matança teria sido motivada pela disputa entre os dois grupos, que disputavam o poder na região. De um lado, o grupo liderado por Manuel Mendes Leitão (conservador), e de outro, os liderados por Manoel Alves Pereira (liberal).

Os "tristes acontecimentos de São José dos Pinhais" ganharam grande repercussão nos meios políticos do período. Seja em documentos oficiais que lamentavam que os partidos recorressem à força física, e buscassem 
"o triunfo da urna com o bacamarte", como consta no Relatório do Presidente de Província do Paraná, Zacarias de Góes e Vasconcelos (1854), ${ }^{84}$ seja em jornais contemporâneos, como o Aurora Paulistana, ${ }^{85}$ de 29 de novembro 1852, que dedicou quase duas páginas para narrar aquelas "deploráveis ocorrências".

Aliás, a depender da fonte, a culpa pelo conflito poderia ser atribuída a um grupo diferente. Desse modo, os responsáveis poderiam ser da oposição liberal, que "ebria pela deslocação em que se acha", tinha concebido um plano para vencer aquelas eleições "e para este fim posera em disponibilidade ardis, corrupção e força", como cravou o periódico paulista (Aurora Paulista, 1852, p. 1). Mas, por vezes, os acusados eram os conservadores que, politicamente fracos na região, buscaram a força da máquina pública, "sob pretexto de manter a ordem", para obter o controle das eleições, como afirmou, cem anos depois do ocorrido, o então deputado estadual Dario Marchesini, por ocasião das comemorações do centenário da emancipação de São José dos Pinhais (MAROCHI, 2003).

Enfim, independente de quem teria dado o primeiro tiro, apreende-se desse caso que, apesar do Ato Adicional (Lei no 16, de 12 de agosto de 1834) ter contribuído para esvaziar significativamente o poder das comunidades locais - sobretudo, ao conceder às Assembleias Legislativas Provinciais a competência para organizar o Poder Judiciário -, as câmaras Municipais ainda eram objeto de cobiça das elites nas vilas e freguesias do império. As ocorrências na vila de São José dos Pinhais são emblemáticas neste sentido.

\footnotetext{
84 VASCONCELOS, Z. G. (1854). Relatório do Presidente da Província do Paraná Conselheiro Zacarias de Goes e Vasconcelos na Abertura da Assembléia Legislativa Provincial em 15 de julho de 1854. Curitiba: Typografia de Cândido Martins Lopes.

${ }^{85}$ As eleiçoens de Coritiba. In: Aurora Paulistana, São Paulo, ano 2, n. 82, 29 nov. 1852, p. 1-2. Disponível em: <http://200.144.6.120/uploads/acervo/periodicos/jornais/AP18521129.pdf>.
} 


\section{Considerações finais}

Esta pesquisa buscou efetuar um estudo de caso que contribuisse com os estudos sobre o período conhecido como Brasil Império e, consequentemente, sobre a parca produção histórica dedicada a São José dos Pinhais, sobretudo durante a segunda metade do século XIX.

Derivada das inquietações pessoais do autor e das pesquisas realizadas durante a graduação, este trabalho ambicionou esclarecer alguns pontos acerca da história de São José dos Pinhais. Embora o número de trabalhos tenha aumentado significativamente nos últimos anos, a historiografia regional ainda tem se dedicado pouco ao estudo dessa região, o que explica a escassa produção especializada sobre o tema.

Conforme os dados apresentados, a massa de votantes sãojoseenses era bastante heterogênea, apesar do recorte censitário. Além disso, foi possível identificar uma forte hierarquização entre as diferentes categorias de homens livres existentes, que era habilmente manejada pelos potentados locais.

A bibliografia especializada tem salientado que o clientelismo permeava e moldava as relações sociais do período. Dessa forma, o pesquisador que almeja compreender as relações de poder nessa sociedade não deve ignorar a influência e a importância dessas estratégias para a vida daqueles indivíduos. Assim, a análise das estruturas sociais das pequenas vilas do Império pode contribuir significativamente para uma melhor compreensão das relações de poder perpetradas na sociedade brasileira do século XIX, como um todo.

Ao passarmos pelos quarteirões de São José nos anos do Império do Brasil, notamos que apesar de se tratar de uma sociedade notadamente agrária e dependente da produção das lavouras, o poder (ao menos o econômico) estava concentrado nas mãos dos negociantes. Nesse sentido, 
as relações perpetradas entre negociantes e lavradores eram desiguais e rendiam bons lucros aos primeiros. Esta pesquisa, portanto, corrobora com Lima, quando afirma que a situação do Paraná ao longo dos séculos XVIII e XIX era a de indivíduos que conseguiam ter relativa facilidade de acesso autônomo à terra, mas a troco de forte pressão para se verem excluídos do acesso a outros fatores, para endividar-se e para obedecer (LIMA, 2007). Portanto, conforme os dados apresentados, acreditamos que São José dos Pinhais se encaixava nessa descrição.

Isso posto, esta pesquisa pode contribuir para uma melhor compreensão das tramas existentes no interior da elite são-joseense de meados do século XIX, bem como das suas estratégias para manter sua posição social. Além disso, a análise de uma sociedade empobrecida, mas, nem por isso, menos hierarquizada, pode contribuir sobremaneira para as análises acerca do papel do teatro das eleições para aqueles que exerciam o poder local no período.

Por fim, espera-se que os dados apresentados, auferidos de diferentes documentos, tenham contribuído para uma melhor compreensão da realidade vivenciada pelas pessoas residentes nesta vila paranaense em meados do oitocentos. E, embora não sejam conclusivas, as informações apresentadas nesta pesquisa podem indicar caminhos interessantes para futuras pesquisas, bem como contribuem para esclarecer um pouco mais sobre a ainda pouco estudada história de São José dos Pinhais.

\section{REFERÊNCIAS}

ALMEIDA, A. M. D. de. Cidadania no Brasil: a construção nacional do Império ao golpe de Estado. In: Revista de Ciências do Estado, [S. I.], v. 5, n. 1, p. 1-22, 2020. Disponível em: <https://periodicos.ufmg.br/index.php/revice/article/view/e15391>. Acesso em: 10 jan. 2021.

As eleiçoens de Coritiba. In: Aurora Paulistana, São Paulo, ano 2, n. 82, 29 nov. 1852, p. 1-2. Disponível em: <http://200.144.6.120/uploads/acervo/periodicos/jornais/AP18521129.pdf>. Acesso em: 10 jan. 2021.

BORGES, L. A. G.. Particularidades familiares. A trajetória de Manuel Mendes Leitão no Paraná, século XIX. 175 f. Dissertação (Metrado em História) - Setor de Ciências Humanas, Letras e Artes, Universidade Federal do Paraná, Curitiba, 2009.

COLNAGHI, M. C.; MAGALhÃES FILHO, F. B. B.; MAGALHÃES, M. D. B.. São José dos Pinhais: a trajetória de uma cidade. Curitiba: Editora Prephacio, 1992.

CARVALHO, J. M de. Mandonismo, Coronelismo, Clientelismo: Uma Discussão Conceitual. In: Dados, Rio de Janeiro, $\mathrm{v}$.

40 ,

2, 1997.

Disponível

em: 
<http://www.scielo.br/scielo.php?script=sci_arttext\&pid=S001152581997000200003\&lng=en\&nrm=iso>. Acesso em: 02 fev. 2008.

CARVALHO, J. M de. A construção da Ordem: a elite política imperial. Teatro das Sombras: política imperial. 2. ed. Rio de Janeiro: Editora UFRJ; Relume-Dumará, 1996.

CARVALHO, J. M de. A involução da participação eleitoral no Brasil, 1821-1930. In: CARVALHO, José Murilo de. \& CAMPOS, Adriana Pereira. (Org). Perspectivas da cidadania no Brasil Império. Rio de Janeiro, Civilização Brasileira, 2011

CONRAD, R.. Os últimos anos da escravatura no Brasil: 1850-1888. Trad. Fernando de Castro Ferro. Rio de Janeiro: Civilização Brasileira, 1978. (Apêndice II).

COSTA, L. C. B. F.. Arraial e Coronel: dois estudos de história social. São Paulo: Editora Cultrix, s/d.

COSTA, G. S. da. Nos quarteirões de São José: um estudo sobre poder e sociedade em São José dos Pinhais na segunda metade do século XIX (1852-1878). 45 f. (Trabalho de Conclusão de Curso [monografia]). Setor de Ciências Humanas, Letras e Artes, Universidade Federal do Paraná, Curitiba, 2008

CUNHA, A. G. L.. Casos negros e pardos livres de mobilidade ascendente no Paraná do século XIX. $71 \mathrm{f}$. (Trabalho de Conclusão de Curso [monografia]) - Setor de Ciências Humanas, Letras e Artes, Universidade Federal do Paraná, Curitiba, 2016.

FERNANDES, E.. Os votantes numa população de fronteira: Lençóes, segunda metade do século XIX. In: Revista de História Econômica \& Economia Regional Aplicada, Juiz de Fora, v.1, n.3, 2007

FERREIRA, M. R.. A evolução do sistema eleitoral brasileiro. Brasília: Senado Federal, 2001.

FRAGOSO, J.. Para que serve a história econômica? Notas sobre a história da exclusão social no Brasil. In: Estudos Históricos, Rio de Janeiro, n. 29, 2002.

GOMES NETO, A. S.. O fundo de emancipação de Escravos: funcionamento e resultados no Termo de Lages, Santa Catarina. Trabalho apresentado no II Encontro Escravidão e Liberdade no Brasil Meridional. LagesSC, 2005.GRAHAM, R.. Clientelismo e política no Brasil do século XIX. Rio de Janeiro: Editora UFRJ, 1997. LIMA, C. A. M.. Os patrimônios e o declínio da escravidão no Paraná (São José dos Pinhais, 1852-1886). In.: CONGRESSO BRASILEIRO DE HISTÓRIA ECONÔMICA, Rio de Janeiro, 6., 2005; CONFERÊNCIA INTERNACIONAL DE HISTÓRIA DE EMPRESAS, Rio de Janeiro, 7., 2005,. Anais... Rio de Janeiro: ABPHE, 2005.

LIMA, C. A. M.. A distância na carne: mundo agrário, escravidão e fronteira nos campos de Curitiba (séculos XVIII e XIX). In: VII Congresso Brasileiro de História Econômica e 8a Conferência Internacional de História de Empresas, Aracaju, 2007. VII Congresso Brasileiro de História Econômica e 8a Conferência Internacional de História de Empresas - Anais... Aracaju: ABPHE, 2007.

LOTT, M. M.. Sob o badalar dos sinos o ar da modernidade, Ouro Preto: população, família e sociedade (1838-1897). 466f. Tese (Doutorado em História). Faculdade de Filosofia e Ciências Humanas, Universidade federal de Minas Gerais. Belo Horizonte, 2009.

MACHADO, C.. A Trama das Vontades: Negros, pardos e brancos na produção da hierarquia social (São José dos Pinhais - PR, passagem do XVIII para o XIX). $343 \mathrm{f}$. Tese (Doutorado em História). Instituto de Filosofia e Ciências Sociais, Universidade Federal do Rio de Janeiro, Rio de Janeiro, 2006.

MAROCHI, M. A.. Câmara Municipal de São José dos Pinhais: 150 anos (1803-2003). São José dos Pinhais/ PR: Câmara Municipal, 2003.

MATTOS, I. R. de. O tempo Saquarema. São Paulo: HUCITEC, 1987.

MOREIRA, G. A. C.. Uma família no Império do Brasil: os Cardoso de Itaguí (um estudo sobre economia e poder). 230f. (Mestrado em História). Centro/Departamento ou Faculdade, Univerdidade Federal Fluminense, Niterói, 2005.

MUAZE, M. de A. F.. O Império do Retrato: família, riqueza e representação social no Brasil oitocentista (18401889). 402 f. Tese (Doutorado em História). Instituto de Ciências Humanas e Filosofia, Universidade Federal Fluminense, Niterói, 2006.

NEVES, L. M. B. P. das; MACHADO, H. F.. O Império do Brasil. Rio de Janeiro: Nova Fronteira, 1999.

NUNES, N. F. M.. A experiência eleitoral em Campos dos Goytacazes (1870-1889): frequência eleitoral e perfil da população votante. In: Dados, Rio de Janeiro, vol. 46, no. 2, 2003, p. 311-343. Disponível em: <http://www.scielo.br/scielo.php?script=sci_arttext\&pid=S0011-52582003000200005\&lng=pt\&nrm=iso >.

Acesso em: 10 jan. 2021.

PEREIRA, M. R. M.. Semeando Iras rumo ao progresso. Curitiba: Editora UFPR, 1996.

SBRAVATI, M.. São José dos Pinhais, 1776-1852: uma paróquia paranaense em estudo. 187f. Dissertação (Mestrado em História). Setor de Ciências Humanas, Letras e Artes, Universidade Federal do Paraná, Curitiba, 1980.

SCHWARCZ, L. M.. Um debate com Richard Graham ou: "com Estado, mas sem nação: o modelo imperial brasileiro de fazer política". In: Revista Diálogos, Vol. 01, nº 05, 2001. 


\title{
JOGANDO COM A IDADE MÉDIA: UMA PROPOSTA DE ESCAPE ROOM DIGITAL
}

\author{
Mariana Bonat Trevisan 86 \\ Renan da Cruz Padilha Soares ${ }^{87}$
}

Resumo: As reflexões sobre como as TIC's (Tecnologias de Informação e Comunicação) afetam o processo de ensinoaprendizagem têm se intensificado e no contexto pandêmico dos anos 2020-21. Os professores se depararam com a necessidade urgente de adaptar metodologias para o ensino remoto. Tendo em vista esse contexto, foi proposta a criação de um jogo didático ambientado na Idade Média, a partir da utilização de ferramentas digitais e da internet. Parte-se de uma discussão teórico- metodológica acerca do uso das tecnologias na Educação e da aprendizagem baseada em jogos e se repensa o estudo de períodos e conteúdos específicos na disciplina de História, tendo em conta os recentes debates no Brasil sobre a Base Nacional Comum Curricular (BNCC, 2018). É discutida a questão de por que estudar a Idade Média no Brasil, as perspectivas da História Pública e dos usos da Idade Média nos meios não-acadêmicos, aborda-se uma perspectiva decolonial sobre o período, propondo a partir de um Escape Room Medieval incorporar novas abordagens ao ensino de História Medieval na Educação Básica.

Palavras-chave: Ensino de História. Idade Média. Aprendizagem baseada em jogos. TIC's.

${ }^{86}$ Currículo Lattes: http://lattes.cnpq.br/2133032033796460.
${ }^{87}$ Currículo Lattes: $\underline{\text { http://lattes.cnpq.br/6341626371059889. }}$. 


\section{Introdução: Tecnologia digital e educação}

Nossa proposta, no presente texto, envolve a criação de um jogo com propósitos didáticos, ambientado no contexto da Idade Média, utilizando ferramentas digitais e a internet. Para tanto, precisamos começar refletindo sobre a relação entre tecnologia digital e a educação.

Não é de hoje que muitos pesquisadores na área da Educação têm se debruçado sobre como as chamadas Tecnologias de Informação e Comunicação (TIC's) afetam o processo de ensino-aprendizagem. Isso se justifica. O rápido avanço da tecnologia digital em nossa sociedade transformou não só a forma como nos comunicamos, como, também, a forma como nos relacionamos e aprendemos.

Já no final do século passado, Castells apontava: "Uma revolução tecnológica concentrada nas tecnologias de informação está remodelando a base material da sociedade em ritmo acelerado" (2000, p. 21). Com base nos estudos de Castells, Mendonça afirma:

Esses estudos mostram que as sociedades digitais promovem a expansão de epstemologias, nas quais novas habilidades e capacidades são exigidas, considerando novas formas de participação social e profissional que delas emergem. (2018, p. 107)

Ou seja, a partir das transformações causadas pelas novas tecnologias de informação e comunicação, já anunciadas por Castells no final do milênio passado, transformam-se não só as estruturas sociais, como, também, exigem o conhecimento de novas habilidades. Cada vez mais os espaços de aprendizagem são múltiplos, porém, isso não retira da instituição escolar o papel privilegiado de transmissão dos saberes acumulados às futuras gerações. 
Para que essa transmissão seja eficiente, contudo, a escola precisa estar completamente conectada com a realidade ao seu redor. Lessard e Tardif, analisando as transformações do ensino atual, apresentam um quadro sobre os estudantes não muito animador. Eles descrevem que,

Para certos escolares, nada mais é como antes: a escola e o esforço para aprender não fazem muito sentido para certos jovens; embora eles sejam rebeldes ativos ou passivos silenciosos, [...] um grande número de jovens vive a escola como uma passagem obrigatória, uma imposição do meio familiar e da sociedade, e não como uma experiência significativa da qual eles poderiam tirar proveito pessoal. (2020, p. 258)

Seria simplista apresentarmos uma única causa para esse quadro. No entanto, para o nosso foco neste texto, debruçar-nos-emos sobre a seguinte análise de Prensky:

Os professores e alunos de hoje pertencem a mundos totalmente diferentes. A maior dinâmica na qual se baseiam o treinamento e a aprendizagem de hoje é o choque turbulento e abrupto entre um corpo de professores criados em uma geração pré-digital, educados nos estilos do passado, e um grupo de aprendizes criados no mundo digital. (2012, p. 33)

Esse choque geracional apontado por Prensky dá-se pela própria velocidade em que as tecnologias digitais avançam, mas não só. Há diversos problemas relacionados à formação inicial e continuada, muitos deles envolvendo estrutura e gestão, que dificultam a atualização desses profissionais. Este não é o espaço para nos aprofundarmos nesse debate, mas isso nos mostra um sintoma de que o avanço rápido dessas tecnologias mudou a forma como os estudantes aprendem nos dias de hoje.

O mesmo autor, então, questiona como a geração atual se difere das gerações passadas e reflete que 
[...] ao crescer com videogames na velocidade twitch, MTV (mais de 100 imagens por minuto) e a velocidade ultrarrápida dos filmes de ação, a mente foi programada para se adaptar a uma rapidez maior e obter êxito nisso. (PRENSKY, 2012, p. 82).

Uma geração cujo aprendizado tem influência direta da tecnologia digital não pode entrar em uma instituição de ensino e se ver em um mundo completamente descolado daquele em que está acostumada a viver. Por isso, precisamos afirmar a importância da utilização de tecnologia digital na escola. Mendonça escreve que esse tipo de tecnologia "é fundamental, pois viabiliza práticas sociais atuais, que precisam ser tematizadas e experimentadas na escola" (2018, p. 109).

Está claro, portanto, que não podemos ignorar as TICs e sua importância para a Educação. É preciso, contudo, aprofundarmo-nos um pouco mais nos desafios que isso representa.

\section{A panaceia da tecnologia como solução para todos os problemas da Educação}

Não é raro lermos textos recentes e ouvirmos palestras sobre a "Educação 4.0" e sua mais recente evolução, a 5.0. Em todos os casos, a tecnologia digital é, muitas vezes, elevada a um patamar de quase adoração e, sendo esse o objetivo, explícito ou não, apresentada como a solução de todos os problemas da Educação no Brasil e no mundo. Nesse raciocínio, Karsenti irá ponderar: 
É forçoso constatar, [...] que infelizmente, de modo geral, parece que se recorre a esses meios mais pela atração do novo e do moderno do que para os objetivos precisos de formação (2020, p. 185).

Como afirmamos, não negaremos o papel preponderante que a tecnologia digital ganhou na sociedade como um todo e na Educação em particular. Ainda assim, a partir de 2020 vivemos um acontecimento de escala global que colocou a relação entre as novas tecnologias e a Educação sob uma lupa. Falamos da pandemia da COVID-19.

Tal acontecimento e suas consequências expuseram, contraditoriamente, a importância da tecnologia digital para o processo de ensino aprendizagem e acentuou as desigualdades sociais e regionais. Educadores foram forçados a trabalhar com diversos tipos de plataformas digitais possuindo pouco, ou nenhum, treinamento e recurso para isso.

Karsenti, pensando na preparação dos profissionais da educação para lidar com as TIC, escreve: "Os futuros docentes [...] não devem necessariamente fazer cursos sobre tecnologias, mas, antes, 'vivê-las' em todos os cursos" (2020, p. 182). Ou seja, o autor aponta que pouco adianta tentar ensinar aos professores sobre ferramentas digitais na Educação, se eles não viveram cotidianamente essas ferramentas em sua formação.

A pandemia evidenciou a necessidade do domínio dessas tecnologias, mas também a fragilidade do nosso sistema de preparar os educadores para sua utilização. E não há como retirar o educador dessa equação. Mesmo as novas metodologias para o ensino apontam que o papel do professor ganhou ainda mais importância, ainda que o foco seja, cada vez mais, o estudante. 
Ficou claro que as TICs não criam, sozinhas, uma educação de qualidade. Precisamos lutar

[...] contra a tendência a ver as TICs como uma solução por sua própria natureza. [...], o alto nível de tecnologia não garante de facto a sua qualidade e ainda menos a sua pertinência educativa (KARSENTI, 2020, p. 185).

Acrescentemos a essas questões a própria desigualdade de infraestruturas entre diversos tipos de instituições escolares no Brasil. Na proposta de atividade pedagógica que apresentaremos nesse artigo estamos atentos às questões que refletimos até aqui e outras que analisaremos mais adiante. O jogo Escape Room pedagógico é a adaptação de uma atividade física para uma plataforma digital, podendo, portanto, ser readaptada para o meio físico, expandindo sua aplicabilidade.

A própria linguagem dos jogos dialogará com essa geração digital de forma mais fácil. $E$, por isso, precisamos analisar o que é a Aprendizagem Baseada em Jogos.

\section{Aprendizagem Baseada em Jogos}

Para compreendermos a utilização de um jogo em sala de aula precisamos, primeiramente, conceituar o próprio jogo. Isso pode parecer desnecessário, visto que, para muitos, "jogo" é um conceito óbvio. Mas não é bem assim. Você sabe diferenciar o jogar, do brincar, por exemplo? Vamos começar por aí.

Huizinga, um dos mais importantes teóricos dos jogos, resumiu o conceito de jogo nas seguintes palavras: 
[...] poderíamos considerá-lo uma atividade livre, conscientemente tomada como 'não-séria' e exterior à vida habitual [...]. É uma atividade desligada de todo e qualquer interesse material, [...] praticada dentro de limites espaciais e temporais próprios, segundo uma certa ordem e certas regras. (2000, p.13)

Algumas delimitações que o autor faz já nos permitem traçar as primeiras diferenças entre jogar e brincar. Ele aponta que o jogo acontece em limites espaciais e temporais pré-definidos, assim como a utilização de regras. Ou seja, diferente do simples ato de brincar, o jogo apresenta limites pré-estabelecidos através de um conjunto de regras.

Porém, outro elemento que o autor aponta nos chama a atenção. Ele trata o jogo como uma atividade "não séria". Pensando que estamos lidando com Educação e isto é algo muito sério, por que deveríamos, então, utilizar uma atividade classificada como "não séria"? O próprio Huizinga esclarece:

Estamos habituados a considerar o jogo e a seriedade como constituindo uma antítese absoluta. Contudo, parece que isto não permite chegar ao nó do problema. Prestemos um momento de atenção aos seguintes aspectos. A criança joga e brinca dentro da mais perfeita seriedade, que a justo título podemos considerar sagrada. Mas sabe perfeitamente que 0 que está fazendo é um jogo. (2000, p.17)

Ou seja, para o autor, considerar o jogo uma atividade "não séria" refere-se ao fato de que quem joga tem a consciência de que aquilo não se trata da realidade concreta. E isto, longe de ser um problema para nós educadores, será um trunfo, como veremos mais adiante.

Kapp é outro autor que segue a linha de Huizinga sobre os jogos, quando enuncia que "jogo é um sistema de realidade abstrata que guia os jogadores para usarem regras, interatividade e feedback" (KAPP, 
2012 , p. 2). Kapp destaca o fato de o jogo ser um sistema de "realidade abstrata", ou seja, não se trata da realidade concreta, como Huizinga já havia dito.

Porém, o autor coloca outros elementos interessantes de serem observados. Ele reafirma a importância das regras e acrescenta "interatividade" e feedback. Portanto, para Kapp, um jogo precisa possuir esses elementos para ser, assim, caracterizado. Já que estamos falando sobre o que compõe e define um jogo, vamos analisar o que Presnky classifica como elementos estruturais de um jogo. Ele aponta seis deles: "regras; metas ou objetivos; resultados e feedback; conflito/competição/desafio/oposição; interação e representação ou enredo" (2012, p. 172).

Percebam que o autor reafirma diversas características já abordadas pelos outros autores aqui analisados e acrescenta algumas. Esses seis elementos considerados estruturais serão importantes para nosso trabalho, pois buscaremos analisar se a nossa proposta de jogo atende a todos ou à maioria deles. E isto é de suma importância, pois são essas as características capazes de motivar um jogador ao ponto de ele imergir naquele jogo e divertir-se com isso. É esta imersão, provocada pela motivação, que classifica os jogos como ótimas ferramentas de aprendizagem.

Seguindo na análise de Prensky, a aprendizagem baseada em jogos digitais funciona por três razões fundamentais. A primeira seria o "envolvimento". Para o autor, o envolvimento do estudante relaciona-se com o fato de a aprendizagem ser colocada no contexto de um jogo, o que quebraria o peso relacionado à aprendizagem tradicional. Prensky aponta também o "processo interativo de aprendizagem empregada", como vimos, o elemento da interatividade é essencial para o jogo. E, por fim, indica "a maneira como os dois são unidos no pacote total", relacionando as duas razões. (2012, p. 209) 
Portanto, tais razões angariam grande potencial para a aprendizagem baseada em jogos. Vamos aprofundar um pouco mais essa questão. Sena et. alli. fazem um importante apontamento nesse sentido,

[...] o jogo cria um ambiente de aprendizagem que incorpora conteúdo acadêmico de modo fluido e que engaja os estudantes, proporcionando oportunidades para a construção do conhecimento para um futuro no qual o aprendizado será ainda mais técnico e complexo. (2016, p. 9)

Ou seja, o ambiente divertido, motivador e imersivo criado pelo jogo é capaz de fazer com que o conteúdo trabalhado em sala seja aprendido de forma mais fácil. O próprio Prensky concorda nesse âmbito, indicando que " $\mathrm{A}$ aprendizagem baseada em jogos digitais pode desempenhar um papel importante na interiorização de conteúdos que não motivem as pessoas [...], mas que precisam ser aprendidos" (2012, p. 44).

Compreendemos, portanto, que o jogo cria esse ambiente facilitador do aprendizado. Mas como? Antoni e Zalla expressam esta ideia ao apontar que:

[...] antes de corresponder a uma simples e despretensiosa atividade, o jogo traz em si uma gama bastante grande de significados e representações. Constituiu-se, portanto, ao longo da história, como um mecanismo de aprendizado de conhecimentos não formais. (2013, p.150, grifo do autor)

Essas "representações" já foram enunciadas quando Prensky enumerou os elementos estruturantes de um jogo. Serão elas de suma importância para o aprendizado baseado em jogos, principalmente no contexto do ensino de História. Isso porque, sendo um jogo um sistema de realidade abstrata, o estudante terá contato com representações da realidade, em um ambiente controlado e metodologicamente pensado 
para estimular o aprendizado. O jogo permite uma vivência prática simulada. Podemos compreender, portanto, o potencial de sua utilização no ensino de História, cuja vivência prática se mostra por vezes tão difícil.

Nossa proposta de jogo digital está especialmente preocupada com a vivência imersiva em uma atividade simulada e lúdica. Porém, outro elemento essencial dos jogos merece nossa atenção. Quando falamos em jogar, logo poderá vir em mente uma atividade competitiva. E isto não é por acaso. Huizinga afirmou nesse sentido que:

Competição possui todas as características formais e a maior
parte das características funcionais do jogo. [...] Quanto a
saber se temos o direito de incluir a competição na categoria
de jogo, podemos sem hesitaçôes responder
afirmativamente." (2000, p. $38-39)$

Porém, a pergunta é válida, como estamos pensando na utilização de jogos em sala de aula, deveríamos, simplesmente, estimular a competição entre nossos alunos? A resposta pedagogicamente responsável é não. Mas isto não é problema, pois, se a competição é um elemento importante dos jogos, a colaboração é tão importante quanto. Para Alves, cooperação e competição, "apesar de opostas, ambas promovem no jogador o desejo de estar com outras pessoas engajado em uma mesma atividade" (2015, p. 45). Ou seja, ambos elementos estimulam a interatividade, algo que nos é caro.

Ainda assim, precisamos estar atentos ao elaborar e aplicar um jogo em sala de aula, procurando focalizar os aspectos colaborativos dos jogos. Isso porque, 
a troca de ideias, tornando-se num exercício de diálogo, consenso e decisão em grupo, apoiado por práticas e experiências potencializadoras de criatividade, de participação e de investigação. (CARVALHO, 2015, p. 177)

É esse estímulo à socialização, ao diálogo e à troca de ideias que buscamos na proposta do Escape Room digital, tendo como contexto escolhido para sua ambientação a Idade Média. É através da interação em um jogo essencialmente colaborativo que buscaremos facilitar a compreensão dos conteúdos propostos para o ensino do período medieval. Essa compreensão é facilitada pois, como apontam Caríssimi e Radünz,

\begin{abstract}
A utilização do jogo na sala de aula oportuniza ao aluno a interação social, a 'emoção' que o jogo permite, a investigação, o levantamento das fontes, a interpretação e a autonomia na produção da narrativa histórica, oportunizando o conhecimento significativo e a construção da consciência histórica. (2017, p. 49)
\end{abstract}

Ou seja, se os jogos possuem grande potencial como ferramenta pedagógica em geral, quando lançamos nosso olhar para as especificidades da História, esse potencial só se eleva. Isso porque, em geral, há dificuldade em se fazer com que o estudante visualize experiências vividas em tempos tão distantes no tempo e no espaço, tal como o contexto medieval. Através da imersão do jogo, no entanto, o educador poderá simular aspectos da daquela sociedade e de sua experiência histórica, a partir de representações do vivido, fazendo com que o estudante, motivado pelos elementos dos jogos, vivencie determinados elementos do período.

Essa vivência, portanto, potencializa a construção da consciência histórica e a realização de conexões passado-presente, bem como a visualização de continuidades, rupturas e permanências entre os tempos históricos. Mas, para isso, o jogo precisa não perder o foco nos elementos motivadores, na colaboração e no conteúdo proposto. 
Vamos, a seguir, analisar como a proposta do jogo poderá atingir esses objetivos.

\section{Escape Room Pedagógico}

Para analisarmos a proposta precisamos entender, primeiramente, o próprio jogo, ou seja, o Escape Room. Wiemker, Elumir e Clare definem Escape Room como sendo

[...] um jogo jogado por uma equipe de pessoas onde eles têm que 'escapar' de uma sala cheia de desafios dentro de um determinado limite de tempo. Para vencer ('escapar'), os jogadores devem resolver os desafios contidos na sala. No início do jogo, os desafios podem ser inacessíveis e devem ser encontrados completando quebra-cabeças. (2015, p. 2)

Interessante observar que o jogo surgiu no meio digital, mas com o tempo passou a ser implementado em meios físicos, como experiências imersivas para grupos de pessoas. Wiemker, Elumir, Clare apontam que

Os Escape Rooms incentivam os jogadores a pensar de forma criativa e a pensar criticamente. Resolver um quebra-cabeça e, finalmente, vencer exigirá que os indivíduos trabalhem nos quebra-cabeças usando várias abordagens de conhecimento. ${ }^{88}$ (2015, p. 3, tradução própria)

Portanto, o jogo, que fez o caminho do digital para o meio físico, ganhará o caminho inverso em nossa proposta. Esse caminho, porém,

\footnotetext{
${ }^{88}$ Original: "In this document, an escape room is a game played by a team of people where they have to 'escape' from a room filled with challenges within a given time limit. In order to win ('escape'), the players must solve the challenges contained within the room. At the outset of the game, the challenges may be made inaccessible and must be found by completing puzzles."
} 
dará a ele uma nova roupagem: o Escape Room digital como jogo pedagógico.

E o que faz do Escape Room um jogo pedagógico eficiente? Carolei, Bruno e Evangelista pontuam que: "As vivências de Escape exigem trabalho em equipe, comunicação, delegação, pensamento crítico, atenção a detalhes, entre outras habilidades." (2018, p.1) Ou seja, um dos motivos é aquele que tanto frisamos ao longo desse artigo: o foco na colaboração.

Mas vai além disso. A experiência imersiva proporcionada pelo Escape Room, permite que a narrativa histórica não seja simplesmente contada, como faríamos em uma aula expositiva comum, mas, sim, vivenciada pelos estudantes. Porém, como destacamos, os escapes atuais trabalham essa questão da imersão e do trabalho em equipe em ambientes físicos. Como faremos, desse modo, o caminho reverso a partir da utilização de um ambiente virtual? Vejamos a seguir.

\section{O ambiente virtual}

Primeiro, justificaremos, de modo bastante pragmático, o motivo pelo qual trazer o jogo de volta para o mundo virtual. No momento em que este artigo é escrito, ainda vivenciamos a pandemia da COVID-19, que levou para o teletrabalho milhões de professores no país inteiro e no mundo. Abordamos já as dificuldades que os educadores passam nessa situação, sem uma formação e suporte condizentes em nosso país. Por isso, nossa proposta pensou em utilizar uma ferramenta digital fácil e disponível para uso gratuito, que pudesse simular a aplicação física do jogo. Portanto, mesmo os profissionais que possuem maior dificuldade em lidar com esse tipo de tecnologia, podem utilizar essa plataforma em seus contextos. E aqueles que - voltando às 
atividades escolares presenciais quando possível e permitido desejarem adaptar o jogo para o modelo físico, também não encontrarão dificuldades.

A plataforma de que estamos falando é o Padlet (https://ptbr.padlet.com/). Na descrição inicial do site, é apresentada a possibilidade de criar quadros, documentos e páginas da web. Nessa breve descrição, já é possível compreender que se trata de uma plataforma bem versátil. Podemos descrever de outra forma, mais sintética: o Padlet é um painel virtual, em que você e outras pessoas podem fazer postagens em tempo real, de forma simples, fácil e gratuitamente.

Por meio do Padlet podemos criar diversos tipos de painéis. Em nosso caso, interessam-nos três tipos específicos: 1) modo tela; 2) modo linha do tempo; 3) modo coluna. No modo tela, os posts ficam espalhados da forma como desejarmos e eles podem ser deslocados de lugar ao serem arrastados. No modo linha do tempo, são organizados em uma linha, podendo ser acrescentados antes ou depois de cada post. Já no modo coluna, os posts ficam organizados por em uma coluna (Figura 1). 
Figura 1 - Modos de criar um Padlet

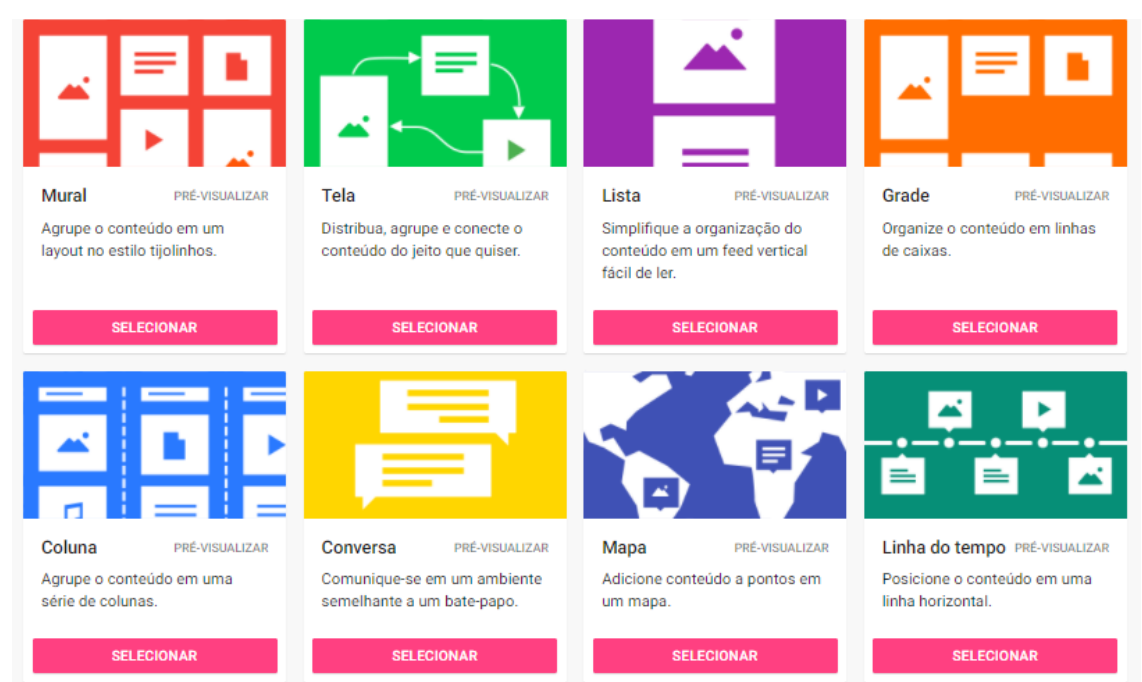

Fonte: $<$ https://padlet.com/create?back=1>.

Perceberam que não utilizaremos uma plataforma de criação de jogos para criar o nosso? Isso porque, mesmo as mais simples feitas com esse objetivo específico, demandariam um conhecimento prévio de educadores e estudantes. Já o Padlet é somente uma plataforma de postagens rápidas e em tempo real, que estamos adaptando para a criação de um jogo. Desse modo, já compreendendo o básico do funcionamento da plataforma, vamos para o jogo em si.

\section{O Escape Room Medieval}

Antes de explicarmos como o jogo é montado no Padlet, é de suma importância entendermos o seu planejamento. Afinal, como qualquer atividade aplicada por um educador em sala de aula, o Escape Room Medieval deve ter um rigoroso planejamento, pensando na melhor forma de incorporar os elementos motivadores 
dos jogos, ao mesmo tempo em que trabalha as habilidades e competências exigidas para o ensino de Idade Média.

Por isso, vale ao professor buscar o que apontam os currículos, entre eles, a própria BNCC (Base Nacional Comum Curricular). Nossa proposta não foca em um ano específico, por acreditarmos que ele é apenas um modelo, que pode ser adaptado pelos professores à sua realidade e para diversos conteúdos e temporalidades.

Tendo em mente o que desejamos trabalhar com nossos estudantes, é preciso, primeiramente montar sua história. Ou seja, a narrativa que será trabalhada, tendo como contexto o espaço e o tempo desejados. A narrativa a que nos referimos aqui é um storytelling, ou seja, um enredo. Algo que, na língua portuguesa de anos atrás, poderíamos descrever como sendo uma "estória".

Em um resumo rápido contaremos a narrativa que criamos para esse Escape. O jogo se passa na segunda metade do século XIV, durante a chamada Baixa Idade Média, no reino fictício de Pinion. A problemática da história se desenvolve a partir do assassinato do rei Pedro III, conhecido pelo epíteto de $O$ Esquemático. Um grupo doutores da Justiça Régia é chamado para descobrir quem matou o rei, o que pode ser determinante para a escolha do sucessor do trono. Entre os personagens, temos evolvidos interesses políticos diversos, ligados à alta nobreza, aos comerciantes da principal cidade do reino, ao reino vizinho de Gaztelu, além de ambições e motivações pessoais de elementos da realeza. Para que possamos visualizar com mais clareza a trama e as personagens do jogo, vejamos o quadro (Quadro 1) a seguir:

\section{Quadro 1 - Personagens do jogo, inserção social e principais atividades na composição do enredo}




\begin{tabular}{|c|c|c|c|}
\hline Personagem & Ligação com o rei & Inserção social & $\begin{array}{c}\text { Atividade } \\
\text { suspeita/interesses } \\
\text { pessoais e/ou } \\
\text { políticos }\end{array}$ \\
\hline D. Pedro III & $\begin{array}{l}\text { É o próprio rei, } \\
\text { personagem cujo } \\
\text { assassinato é o cerne } \\
\text { da trama/jogo }\end{array}$ & Rei de Pinion. & Não há evidência. \\
\hline $\begin{array}{l}\text { Sir Renan / Lady } \\
\text { Mariana }\end{array}$ & $\begin{array}{l}\text { Conselheiro mais } \\
\text { próximo do rei/ irmã } \\
\text { mais velha do rei, } \\
\text { muito próxima a ele }\end{array}$ & $\begin{array}{l}\text { Nobre de alta linhagem } \\
\text { do reino, principal } \\
\text { membro do Conselho } \\
\text { Régio/ conselheira } \\
\text { pessoal do rei. }\end{array}$ & Não há evdência. \\
\hline Rainha Anne & $\begin{array}{l}\text { Esposa do Rei D. } \\
\text { Pedro III }\end{array}$ & $\begin{array}{l}\text { Irmã do Rei Juan de } \\
\text { Gaztelu, ligação com } \\
\text { esse reino por } \\
\text { nascimento. Soberana } \\
\text { do reino de Pinion. }\end{array}$ & $\begin{array}{l}\text { Era tratada com } \\
\text { indiferença e, por } \\
\text { vezes, desprezo, pelo } \\
\text { marido. Tinha } \\
\text { interesse na unificação } \\
\text { das coroas de Gaztelu } \\
\text { e Pinion. Descobre que } \\
\text { o rei havia tido um } \\
\text { filho com outra } \\
\text { mulher. }\end{array}$ \\
\hline $\begin{array}{l}\text { Princesa } \\
\text { Mariane }\end{array}$ & $\begin{array}{l}\text { Filha do Rei D. Pedro } \\
\text { III e da Rainha Anne. } \\
\text { Casada com o filho } \\
\text { do Rei Juan de } \\
\text { Gaztelu }\end{array}$ & $\begin{array}{l}\text { Ligação por nascimento } \\
\text { com o reino de Pinion, } \\
\text { herdeira. Ligação com o } \\
\text { rei de Gaztelu na } \\
\text { condição de rainha. }\end{array}$ & $\begin{array}{l}\text { Muito próxima da } \\
\text { mãe. Não reconhece o } \\
\text { irmão bastardo e teme } \\
\text { pela herança do reino. } \\
\text { Deseja unificação das } \\
\text { coroas de Pinion e } \\
\text { Gaztelu. }\end{array}$ \\
\hline Príncipe Felipe & $\begin{array}{l}\text { Filho primogênito do } \\
\text { Rei D. Pedro III e da } \\
\text { Rainha Anne. } \\
\text { Falecido em batalha } \\
\text { contra mouros. }\end{array}$ & $\begin{array}{l}\text { Inserção e herança do } \\
\text { reino interrompida, } \\
\text { devido ao falecimento } \\
\text { precoce. }\end{array}$ & Não há evidência. \\
\hline $\begin{array}{l}\text { Arquiduque } \\
\text { Jorge }\end{array}$ & $\begin{array}{l}\text { Irmão do Rei } \text { D. } \\
\text { Pedro III. }\end{array}$ & $\begin{array}{l}\text { Ligado à alta nobreza de } \\
\text { Pinion. }\end{array}$ & $\begin{array}{l}\text { Era contrário à } \\
\text { aproximação do Rei } \\
\text { com a burguesia } \\
\text { comercial de Berdea. }\end{array}$ \\
\hline Arthur & $\begin{array}{l}\text { Filho bastardo do Rei } \\
\text { D. Pedro III }\end{array}$ & $\begin{array}{ll}\text { Comerciante } & \text { e } \\
\text { representante } & \text { do } \\
\text { Conselho da Cidade de } \\
\text { Berdea. }\end{array}$ & $\begin{array}{l}\text { Descobre tardiamente } \\
\text { ser filho do Rei. Foi } \\
\text { colocado como } \\
\text { herdeiro do trono. }\end{array}$ \\
\hline Rei Juan II & $\begin{array}{l}\text { Ligações } \\
\text { linhagísticas } \quad \text { (de } \\
\text { parentesco) com o } \\
\text { rei Pedro III }\end{array}$ & $\begin{array}{l}\text { Rei do Reino vizinho, } \\
\text { Gaztelu. }\end{array}$ & $\begin{array}{l}\text { Não estava no palácio } \\
\text { de Pinion, quando o rei } \\
\text { Pedro III foi } \\
\text { encontrado morto. }\end{array}$ \\
\hline Carl Martius & $\begin{array}{l}\text { Convidado pelo Rei } \\
\text { para realizar estudos } \\
\text { científicos no reino. }\end{array}$ & $\begin{array}{l}\text { Físico e botânico judeu, } \\
\text { membro da comunidade } \\
\text { judia do reino, } \\
\text { reconhecido dentro e } \\
\text { fora do reino por seus } \\
\text { saberes. }\end{array}$ & Não há evidência. \\
\hline
\end{tabular}


Fonte: Elaboração dos autores

Este é apenas um resumo. Para o planejamento, foi importante detalhar a história, ainda que brevemente. Após delinear o contexto do jogo, o educador deve colocar em uma linha do tempo os acontecimentos mais importantes que explicam a problemática atual. Desde a coroação do rei Pedro III, até sua morte. Isso será muito importante para a principal etapa, que é a próxima.

Como vimos, no Escape Room, os jogadores precisam lidar com desafios espalhados pelo ambiente, os quais os ajudam a montar um "quebra-cabeças" e, assim, encontrar a saída do lugar. No Escape Room Pedagógico que propomos, o princípio é parecido. Você não precisa escapar, mas precisa solucionar o problema proposto, nesse caso, o assassinato do Rei Pedro III. Para solucionar, será preciso investigar o ambiente e juntar o quebra-cabeças.

Assim, tendo a sua narrativa escrita e a linha do tempo dos acontecimentos, agora você precisa criar os vestígios que contarão essa história. Você, educador, sabe o que aconteceu. Conhece a história. Os estudantes (investigadores), não. E o único contato que eles terão com essa narrativa é através da análise dos vestígios que você irá produzir.

Ou seja, se na narrativa da história é importante o fato de que a princesa Mariane apoia a pretensão do rei de Gaztelu, vizinho à Pinion, de unificar as coroas, isso precisa estar presente em um ou mais dos vestígios. Por exemplo: uma carta de Mariane para a mãe, em que ela relata suas posições políticas. Se o irmão do rei discorda de sua aproximação com os ricos homens da cidade de Berdea (a burguesia citadina), isso precisa estar presente nos vestígios, como, por exemplo, o registro oficial de uma reunião em que o irmão do rei aponta suas preocupações. 
Portanto, a criação desses vestígios é a parte mais importante, pois é somente através deles que os jogadores/estudantes terão contato com a narrativa criada. E é a única forma de solucionarem o problema proposto.

Por isso, você deve ter algumas preocupações. Não facilite demais a solução do problema, por exemplo. Na nossa proposta, o assassino do rei não pode ser óbvio. Foi preciso criar suspeitas plausíveis em pelo menos três personagens. Porém, crie uma pista, de preferência bem escondida, que solucione indubitavelmente 0 problema.

$\mathrm{Na}$ produção de vestígios, não se limite a um só tipo de documento. Crie vestígios imagéticos, como pinturas; vestígios orais, como depoimento dos personagens, que você pode gravar com a ajuda de colegas. Além dos vestígios escritos de tipo oficial, como certidões e decretos, e do tipo pessoal, como cartas. Essa variedade é importante para dinâmica do jogo, mas também para o propósito de sua utilização no ensino de história, como voltaremos a debater mais adiante.

Essa é a base para criação do seu Escape Room Pedagógico, contextualizado na Idade Média. Percebam que, a partir daí, pode implementá-lo, tanto no meio físico, como no meio digital. Nosso foco é sua implementação no meio digital, através do Padlet. Então, vejamos como seria.

Os vestígios produzidos por você devem ser postados em um Padlet modelo tela, onde poderá espalhá-los pelo mural da forma que desejar. Percebam na imagem abaixo (Figura 2) que o fundo escolhido, assim como a descrição do painel, devem favorecer a imersão na história: 
Figura 2 - Páginas de vestígios do Padlet

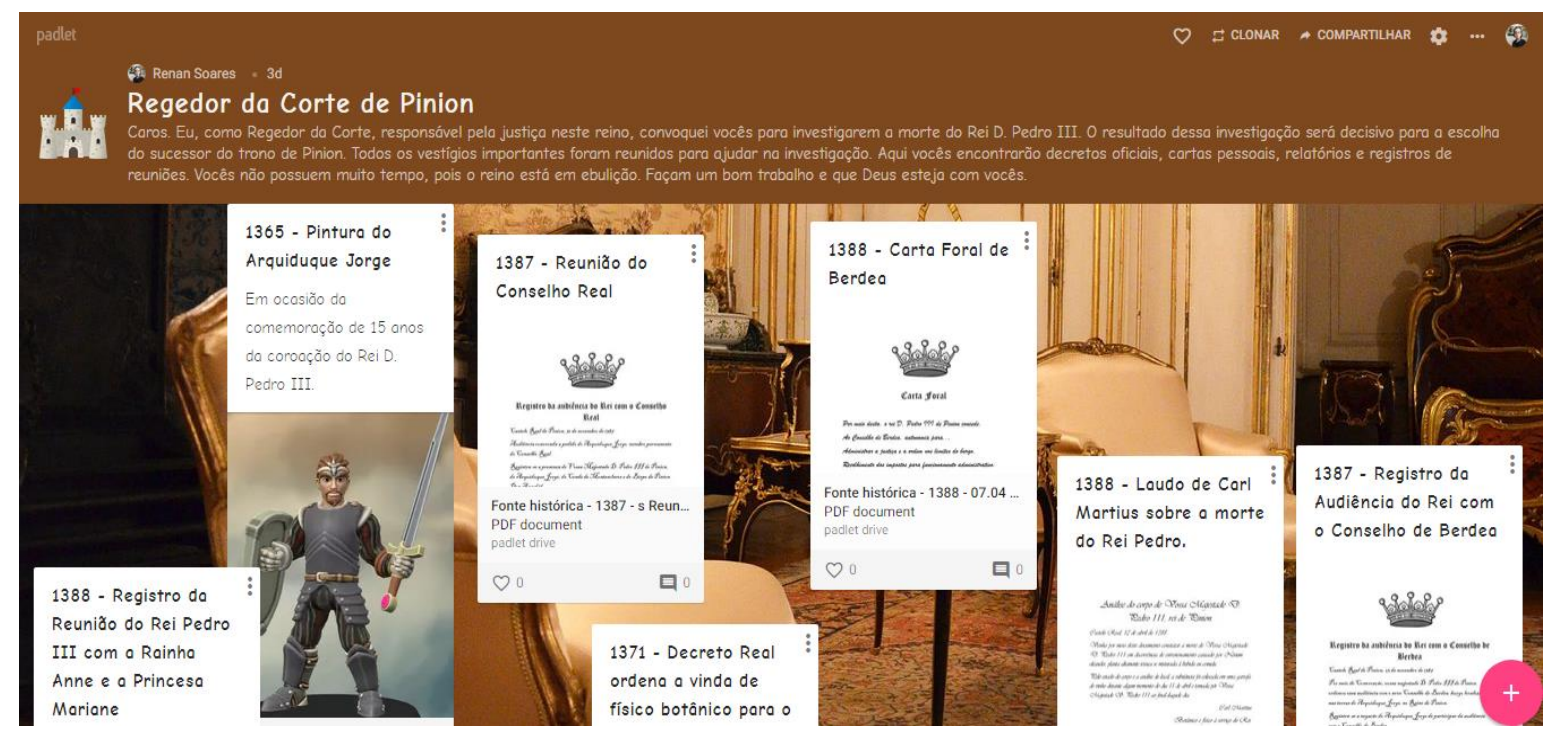

Fonte: <https://pt-br.padlet.com/rencruz89/vestigiosreipedro>

Cada post do Padlet permite adicionar um título, uma descrição e um arquivo, que pode ser um vídeo, uma imagem, um som ou um arquivo escrito. Você deve colocar o nome do vestígio (por exemplo: Carta de Mariane para a mãe), com a data em que foi produzido, e adicionar um arquivo com o vestígio em si. Nas configurações de seu Padlet, poderá permitir que os posts sejam curtidos e comentados. Isso será importante para aplicação, como já veremos.

Outro painel (Figura 3) deve ser criado, esse no modelo "linha do tempo". Também com um fundo imersivo e a descrição do seu objetivo, esse painel deverá ser preenchido pelos alunos, com todos os acontecimentos que eles apurarem através dos vestígios analisados. Isto ajudará muito na organização das ideias e na análise dos acontecimentos.

Figura 3 - Página da linha do tempo no Padlet 


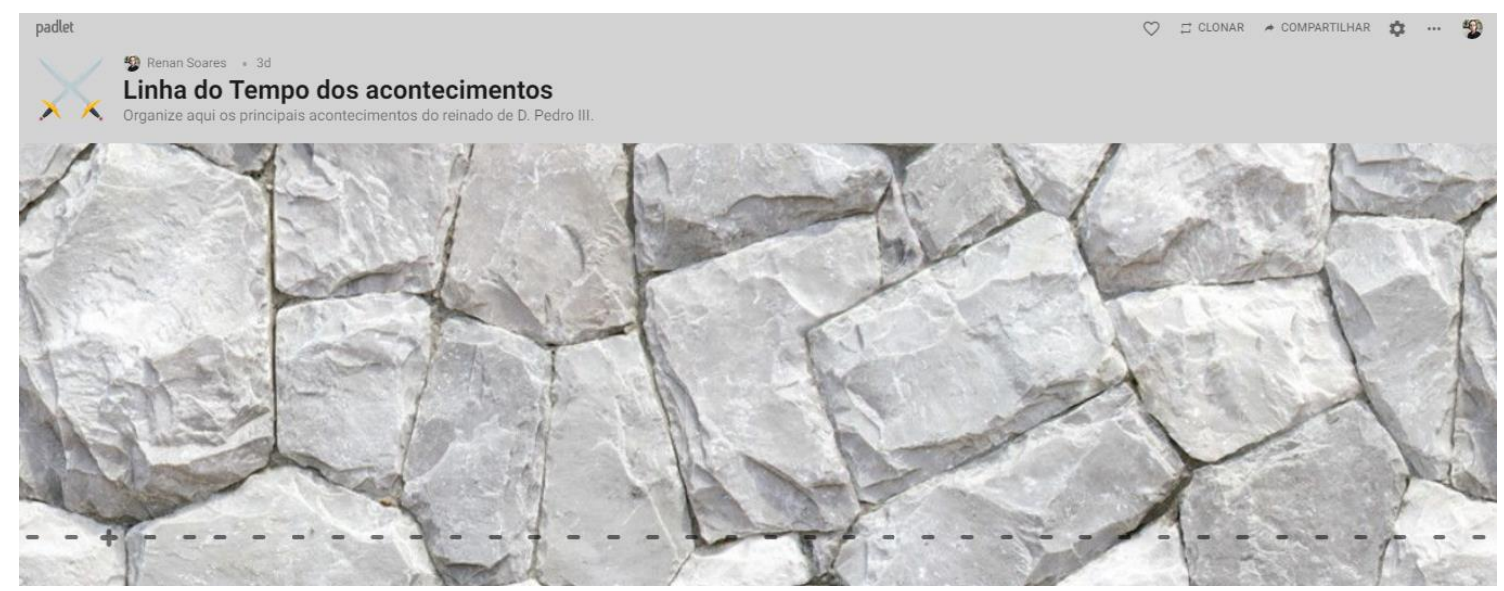

Fonte: <https://pt-br.padlet.com/rencruz89/qai26c1dfafswuli>

Por fim, o painel no modelo "coluna" (Figura 4) deve ser preenchido pelo educador com perguntas orientadoras do trabalho dos investigadores. Essas perguntas, os alunos responderão conforme forem avançando no jogo e são elas: 1) "Quem são os suspeitos e por que?"; 2) "Quais são os conflitos entre os grupos existentes?"; 3) "Quem matou o rei?"; 4) Qual foi a causa da morte?. Este é o mínimo de perguntas, na adaptação para outras realidades, contudo, o educador pode avaliar que serão necessárias outras.

Figura 4 - Página de Perguntas Orientadoras do Padlet

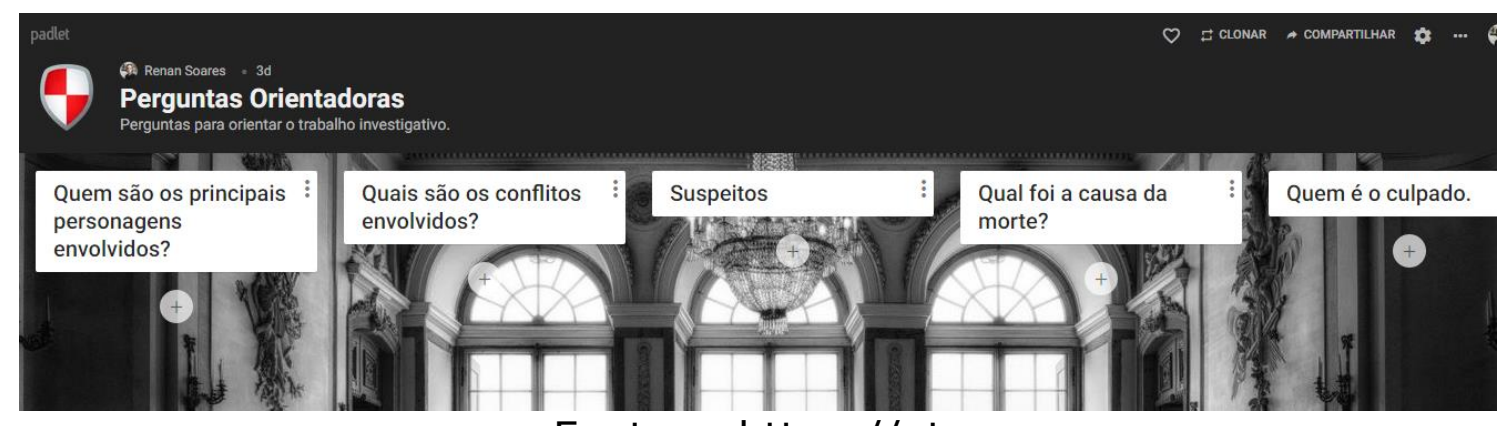

Fonte: < https://pt-

br.padlet.com/rencruz89/perguntasorientadorasescape> 
A importância dessas perguntas orientadoras dá-se pelo fato de que este é um jogo aberto e a organização dos estudantes pode ser um problema. Se eles não estiverem organizados e avançando na dinâmica, podem se frustrar, e o objetivo de motivá-los para alcançar a aprendizagem, perder-se. Nessa organização, as curtidas e comentários em cada postagem podem ser de grande valia. Assim, os estudantes interagem e registram suas opiniões baseadas na investigação realizada em tempo real.

Mas as perguntas orientadoras não bastam. A atuação do professor como mediador do conhecimento é de suma importância. Ele deve contribuir na organização dos estudantes, levantar perguntas, ajudar a fazer conexões, dentre outras coisas. Tal participação também deve ser imersiva e lúdica. Em nosso Escape Room, o professor também está inserido no contexto. Ele pode, por exemplo, estar na figura de "Sir Renan", o conselheiro mais próximo do rei Pedro e responsável por convocar e ajudar na investigação da Igreja; ou então, "Lady Mariana", irmã mais velha e próxima do rei, que também tem um papel conselheiro junto a este. Claro que o professor não precisa interpretar o personagem o tempo todo. Em certos momentos, ele será somente uma "voz da consciência", ajudando os estudantes/investigadores. Mas sua participação ativa não pode ser deixada de lado.

Outra forma de organizar é estipular que o primeiro passo é organizar a linha do tempo. Isso é interessante, pois dará ao estudante a sensação de participar de mais de uma etapa, ou fase, e ajudará na organização das atividades.

Este é o Escape Room Medieval, para Padlet, que propomos neste artigo. Percebam que dos elementos estruturais dos jogos, propostos por Prensky, (regras; metas ou objetivos; resultados e feedback; conflito/competição/desafio/oposição; interação e representação ou 
enredo) o jogo possui todos. Substituindo, somente, o elemento competitivo pela colaboração, essência do Escape Room.

Portanto, entendendo como o Escape Room Medieval funciona, é hora de nos aprofundarmos na análise dos benefícios para o ensino de Idade Média que este jogo pode trazer.

\subsection{Ensino de História Medieval no Brasil: por quê, para quê, como?}

A primeira questão que colocamos aqui, após já termos explicado nosso jogo ambientado na Idade Média e sua dinâmica, é: como a Idade Média se insere em nosso currículo e quais as potencialidades de seu estudo na Educação Básica? Também devemos nos perguntar: por que estudar a Idade Média no Brasil (local que não teve um passado traçado na cronologia tradicional eurocêntrica)? Em que as aprendizagens sobre o período medieval contribuem para a formação da reflexão e criticidade de nossos estudantes?

A Idade Média integra nosso currículo do ensino básico desde a instituição da disciplina de História no país. A partir de Elza Nadai (1993), Geraldo Magella de Menezes Neto (2015, p. 321) pontuou que, com a inserção da História no Brasil a partir do currículo do Colégio Pedro II, no Rio de janeiro de 1838, os alunos começaram por estudar a História da Europa Ocidental, tida como "a verdadeira civilização". A História europeia era o foco do que se considerava a "História Universal". Em estados como São Paulo, o estudo sobre o medievo, já no período republicano, começava a ser feito a partir do $4^{\circ}$ ano do período ginasial, partindo dos "bárbaros germânicos", passando pelo Império Bizantino, Carlos Magno, o feudalismo e o poder da Igreja. Ao longo do tempo, os conteúdos a respeito da Idade Média acabaram por 
privilegiar o viés político e religioso. Rivair Macedo apontou a predominância dessa dimensão nos livros didáticos de nível fundamental e médio. Segundo o autor:

[...] as linhas de rumo que norteiam a reprodução do conhecimento relativo à Idade Média europeia estão ligadas à evolução das formas de governo, isto é, o governo temporal dos reinos e do império, e o governo espiritual/temporal da Igreja; [...] a configuração dos grupos sociais, com particular ênfase das relações de dominação entre senhores feudais e camponeses, ou então na formação e decadência do feudalismo e a germinação do capitalismo moderno (MACEDO, 2015, p. 111).

De modo geral, além da predominância dos acontecimentos políticos e preponderância da Igreja, a Idade Média é retratada não como uma temporalidade rica em si mesma para análise, plena de processos e dinâmicas históricas próprias. Ela continua sendo vista como um interlúdio, uma preparação para algo maior que se concretizaria depois, tal como a economia capitalista (COSER, 2010, p. 3). Nessa mesma senda, Campos e Langer (2007, s/p.) evidenciaram um predomínio ainda da dicotomia civilização X barbárie, na qual povos com culturas não-cristãs, tais como os escandinavos pagãos e os muçulmanos, ganham menor destaque e acabam sendo colocados em uma posição inferiorizada, em vista dos outros, que se cristianizaram e passaram a integrar o que seria denominado de civilização europeia cristã no medievo.

Mais recentemente (após a segunda metade do século $X X$ ), também foram privilegiados aspectos econômicos, até mais do que os sociais, do que se convencionou chamar de feudalismo. Além disso, o ensino também ajudava a reforçar estereótipos existentes no senso comum, referentes à Idade Média como um período de trevas e unicamente de obscurantismo, eleito como o pior de todos os tempos 
históricos (como se em outros contextos não tivessem existido fomes, guerras, pestes, opressões, explorações e tragédias várias).

Bem mais recentemente, praticamente na virada para o século XXI, o ensino de Idade Média agregou algumas das renovações produzidas pela historiografia da segunda metade do século $X X$, mormente produções advindas da História Cultural e algumas reflexões em torno de campos como a História das Mulheres, das Crianças e do Cotidiano. Em documentos como os Parâmetros Curriculares Nacionais (os PCNs), no final dos anos 1990, tais problemáticas começaram a ser incorporadas para o Ensino de História ainda no terceiro e quarto ciclos do Ensino Fundamental (BRASIL, 1998). Em alguns livros didáticos começamos a ver, a partir dos anos 2000, capítulos sobre as mulheres na Idade Média, por exemplo, bem como temas diversos ligados à História Cultural. Mesmo assim, ainda é restrito o espaço concedido ao período medieval no documento, tendo em conta o privilégio da abordagem temática dos conteúdos nos PCNs (MACEDO, 2015, p. 111).

Mas de onde vem esta ideia de um período intermediário, uma "idade no meio de outras", um interlúdio entre tempos mais importantes? Qual seria sua delimitação e por quê? Como afirmou Christian Amalvi em um verbete sobre a Idade Média no Dicionário Temático do Ocidente Medieval: "A Idade Média não existe" (2002, p. 537). Ela é uma delimitação artificial e parcial de um período de existência humana que engloba praticamente mil anos, recorte este criado por europeus e para europeus, imposto ao mundo devido às colonizações europeias e sua longa duração, assimilado e reproduzido no mundo colonizado - tanto na academia, quanto nos meios escolares - e ainda presente hoje.

Tradicionalmente, o medievo é compreendido em nossa divisão cronológica como a trajetória dos séculos $\mathrm{V}$ a XV da Era Cristã. Essa 
convenção temporal foi fabricada a posteriori do tempo em que viveram os que chamamos "medievais". Tal abstração e representação foi concebida pelos humanistas italianos ainda no século XIV (tempo que, curiosamente, hoje ainda incluímos na Idade Média). Eles acreditavam estar vivendo um tempo novo no campo do conhecimento e das artes, recuperando e idealizando elementos da Antiguidade Clássica. Desse modo, passaram a olhar para o tempo imediatamente anterior a si como um medium aevo, uma época intermediária, entre o novo período que acreditavam viver (moderno) e o que consideravam um tempo glorioso mais antigo (a Antiguidade Clássica até à queda do Império Romano do Ocidente) (ALMAVI, 2002, página?)

Desse modo, desde os primórdios de seu advento, a Idade Média já seria marcada por um conceito desvalorizante. Tal processo continuou nas centúrias seguintes, desembocando nos esforços iluministas do século XVIII para aperfeiçoar uma periodização histórica "universal" (que na verdade era calcada na base europeia do que consideravam civilização), assentando a concepção tripartida: Antiguidade, Idade Média, Idade Moderna (lembrando que depois de processos como a Revolução Francesa e as Revoluções Industriais, seria acrescida a Era Contemporânea). Assim, os iluministas continuaram afirmando uma visão sombria do medievo, considerando seu próprio tempo e o porvir como o triunfo da civilização sobre a barbárie, do conhecimento sobre o obscurantismo clerical, generalizando mil anos de história e escamoteando as contradições de seu próprio período e de outros, como a Antiguidade Clássica (BASCHET, 2006, p. 25; ECO, 2011, p. 13-21). Com o tempo, afirma Christian Amalvi, a divisão cronológica passaria a ter um caráter mais didático e menos julgador entre os períodos (AMALVI, 2002, p. 538). Todavia, as marcas da desvalorização e pré-conceitos sobre a época intermediária teriam longa duração. 
Antes de aprofundar essa questão, é importante compreender que processos situamos na divisão cronológica do medievo. Seus marcos iniciais e finais variam, suas divisões internas também, conforme os contextos espaciais e temporais que teorizaram sobre o período (tradições de periodização francesa, alemã, espanhola, etc.). De modo genérico, podemos falar que o começo da Idade Média é traçado a partir de acontecimentos que evidenciaram a decadência do poder imperial romano no Ocidente, tal como o saque de Roma de 410 d.C. e, mais comumente, o destronamento do último imperador romano do Ocidente, Rômulo Augústulo, no ano de 476 d.C.

A partir desse momento, temos a classificação da Alta Idade Média, compreendida como a formação do mundo medieval, que se estenderia até o ano 1000, momento em que se acreditava ter conformado o feudalismo e uma sociedade medieval ocidental. $\mathrm{Na}$ sequência, temos duas possibilidades de periodização mais comumente utilizadas no Brasil, a primeira, no mundo acadêmico, advinda da influência da historiografia medieval francesa em nossa universidade, classifica o medievo em: Idade Média Central (séculos XI- XIII), período no qual a Igreja teria consolidado seu poder no Ocidente e a sociedade feudal atingiria sua conformação plena, o comércio e as cidades se renovariam, entre outros processos; e a Baixa Idade Média (séculos XIV e XV), período marcado pela continuidade da dinâmica feudal junto a aspectos de crise, fomes, pestes e guerras. Contudo, na tradição seguida mais comumente no ensino básico e nos livros didáticos, temos normalmente a divisão bipartida: Alta Idade Média (século V a X) e Baixa Idade Média (séculos XI a XV), delimitando assim a formação da sociedade medieval até o feudalismo e, depois, a plenitude da sociedade feudal até seu momento de crise.

O marco final da Era Medieval também costuma variar, o mais conhecido em nosso ensino é o ano de 1453, queda de Constantinopla, 
que marcaria o fim do Império Bizantino. O medievo é assimilado aqui ao período entre o fim do Império Romano do Ocidente (ano de 476) e o fim do Império Romano do Oriente (Bizâncio). A data de 1492 também é sinalizada em algumas periodizações, pois constitui o ano da chegada de Cristovam Colombo às Américas e da queda do último reduto muçulmano na Península Ibérica, Granada (ECO, 2011, p. 1314; BASCHET, 2006, p. 33-35; SILVA, 2020, p. 142 e 143).

Os marcos temporais têm propósitos didáticos, eles auxiliam a nos localizarmos na abstração do tempo e na compreensão encadeada dos diversos processos históricos. Do mesmo modo, os marcos e periodizações são extremamente redutores das experiências históricas, eles sempre partem de um determinado referencial, fixado a partir de uma concepção prévia, parcial, motivada por questões do presente, que fixa essas delimitações. Como pontuou Rivair Macedo (2015, p. 115), ao se trabalhar a Idade Média em geral, trata-se apenas da Europa e de uma parte específica dela (a Ocidental), justamente aquela em que se situam povos que, na atualidade, detêm posição hegemônica no continente (Inglaterra, França, Alemanha, Itália). Portanto, deixam-se de lado em geral especificidades da Europa do Leste, da Ibérica, da Nórdica. Do mesmo modo, dá-se menor importância aos contextos bizantino, muçulmano e de outros povos na África e Ásia (sem contar o continente americano, que é ignorado como se não tivesse uma história própria neste período). ${ }^{89}$

Todavia, mais importante do que rejeitar totalmente as periodizações, é compreender a parcialidade de cada uma delas, desconstrui-las e pensar em alternativas que não excluam o estudo de

\footnotetext{
89 Uma observação importante nesse sentido é notar como, na Educação Básica no Brasil, os livros didáticos costumam dedicar alguns capítulos ao medievo europeu, enquanto abordam de forma mínima (em geral apenas um capítulo para cada) outros contextos que interagiam com o europeu e tinham suas próprias dinâmicas no período, tais como o mundo muçulmano e os cristãos bizantinos. Já sociedades africanas e do Extremo Oriente aparecem em capítulos mais dispersos, que normalmente não têm uma delimitação cronológica única.
} 
nenhum processo e contexto histórico, pelo contrário, pensar numa concepção histórica cada vez mais ampla e inclusiva, balizada nos estudos e problematizações mais recentes da historiografia e das Ciências Sociais. Sendo assim, como propôs Rivair Macedo, é importante descolonizar o ensino de História, em geral, e de Idade Média, em particular (2015, p. 115).

Nos últimos anos, tivemos as discussões da Base Nacional Comum Curricular (a BNCC). As reformulações indicadas para essa proposta de revisão e padronização curricular nacional atingiram em cheio os medievalistas e o ensino de Idade Média no país. O documento inicial, ao buscar romper com uma narrativa eurocêntrica, centrou-se na História do Brasil, essencialmente a partir do período moderno e das navegações que resultaram na colonização. Buscou também retirar das margens a história indígena e africana (porém, esta última passa a ter importância a partir do contato com a realidade americana, deixando de lado seus contextos anteriores). Tais centralizações geraram diversas críticas de profissionais de diferentes áreas da História, incluindo os medievalistas (LIMA, 2019, p. 3-4).

Em meio aos debates, na terceira e última versão da BNCC, a Idade Média acabou por figurar nomeadamente apenas nos conteúdos do $6^{\circ}$ Ano do Ensino Fundamental II, a partir de temas que privilegiam uma abordagem sociocultural (contatos e circulação de pessoas, organização do trabalho, papel da religião cristã e das mulheres na sociedade medieval), com eixos ligados ao Mediterrâneo (LIMA, 2019, p. 11, 12; BRASIL, BNCC, 2017/18, p. 420).

Com relação aos conteúdos do Ensino Fundamental II, a BNCC (2017/18, p. 547) prevê, portanto, a inserção da abordagem sociocultural, trazendo temáticas como a inserção das mulheres na sociedade e as diferentes formas de organização das famílias no tempo e no espaço. Em nosso jogo de Escape Room Medieval, buscamos 
trazer essas questões, relacionando o papel das mulheres da realeza e como se imbricam neste âmbito social as questões do poder e das relações familiares, buscando levar o estudante a refletir sobre comparações e diferenciações sobre as formas de poder hoje e as dimensões que envolviam as ligações familiares no passado. Assim, ele poderá estabelecer comparações e reflexões entre formas de afeto, relações entre pais e filhos, entre irmãos, etc., aproximando-se de temáticas que dialogam com suas próprias experiências de vida e realidades.

Mesmo não delimitando os conteúdos da área de História a partir de uma visão cronológica, a BNCC para o Ensino Médio (dentro da área de Ciências Humanas e Sociais Aplicadas) também pode ser trabalhada em nossa proposta lúdica pela reflexão em torno das categorias de tempo, espaço, territórios e fronteiras (BRASIL, BNCC, 2017/18, p. 552), num diálogo inter- e transdisciplinar. A questão da disputa territorial entre as monarquias, as alianças e negociações com setores da nobreza e das elites citadinas são processos que o jogo permite vivenciar e discutir. Os estudantes podem assim compreender a formação de processos identitários, tecendo também reflexões sobre as distinções com as questões territoriais, de poder, soberania e jurisdição (envolvendo esferas locais, municipais, regionais, nacionais) no presente e o espaço em que vivem.

A inspiração espacial e temporal para os territórios fictícios (Pinion e Gaztelu) de nosso jogo foi buscada no contexto medieval ibérico, principalmente do século XIV, comumente deixados de lado na abordagem tradicional do ensino básico de História Medieval. Este, em geral, privilegia e enquadra questões relacionadas à monarquia ibérica e seu fortalecimento como conteúdos ligados apenas ao período moderno (conectadas ao advento das grandes navegações e à expansão ibérica). 
Como apontou Rivair Macedo, ao enfatizarmos o contexto histórico da Península Ibérica medieval, o ensino de História Medieval torna-se mais significativo ao estudante brasileiro do que aprofundar conhecimentos sobre o mundo medieval anglófono e francófono (2015, p. 116). É preciso levar em conta que compreender a trajetória dos povos ibéricos é fundamental para a formação da consciência histórica a respeito do conjunto cultural ao qual pertencemos, tendo em vista a dimensão da dominação colonial da América por espanhóis e portugueses. Revelam-se assim aos estudantes aspectos de nosso passado que continuam a interagir com o presente.

Outro diferencial que ganha dimensão social significativa no estudo da Península Ibérica Medieval é o da interação entre diferentes povos e culturas nesse espaço e tempo. A convivência entre diferentes etnias e religiões (entre cristãos, judeus e muçulmanos) no medievo ibérico faz parte da formação histórica desse contexto particular, que também daria especificidades ao processo de colonização e posterior constituição de identidades coletivas no Brasil e na América Latina. As trocas culturais entre os povos permitiram avanços intelectuais e técnicos que interagiram na promoção do contexto da expansão ibérica e das grandes navegações. Por fim, é preciso ressaltar que, ao analisar as questões sociais do panorama histórico europeu medieval, também podemos analisar junto aos alunos como os dilemas foram vividos e quais alternativas foram formuladas naquele espaço, para além até do medievo. Desse modo, o tempo medieval constitui um referencial para a compreensão (seja por distinção ou aproximação) das formas como lidamos hoje com nossas questões e problemas sociais (MACEDO, 2015, p. 116-117).

No tempo em que escrevemos este texto, marcado pela pandemia do coronavírus, crianças e jovens entram em contato cotidianamente pelas mídias com afirmações muitas vezes equivocadas 
e apropriações em torno do conceito de Idade Média diversas, que precisam ser desconstruídas por um ensino crítico e reflexivo. Como pontuado por Renan Birro e Renato Boy:

[...] a cada dia novas manifestações populares - e, vez por outra, de colegas de ofício - continuam a demonstrar publicamente o déficit no conhecimento sobre o medievo através do mau uso do aparato conceitual e temático que diz respeito a este período da História. Em tempos de COVID-19, não é difícil encontrarmos em redes sociais e veículos amplamente consumidos, como vídeos e podcasts de divulgação científica, comparações pouco fundamentadas sobre a pandemia atualmente vivida no mundo e a Peste do século XIV. (2020, p. 6)

Além da questão da pandemia, o avanço de extremismos políticos de direita, no Brasil e no mundo, com cenários políticos conturbados em que a ciência é condenada em nome de crenças e opiniões, em que se propagam elogios e tentativas de revivalismos de poderes autoritários de cariz ultranacionalista, as comparações da atualidade com a Idade Média ganham contornos bastante curiosos, inapropriados e paradoxais, que podem gerar grandes equívocos para as pessoas em geral (estudantes ou não).

Por um lado, os ideólogos e políticos de extrema direita divulgam nas mídias a imagem de uma Idade Média idílica, um tempo perfeito, marcado apenas por uma civilização europeia branca, na figura viril e masculina de cavaleiros honrados, guerreiros, e calcada em apenas no setor aristocrático da sociedade (a nobreza) (PACHÁ, 2019). São deixadas de lado as desigualdades sociais, de gênero, os abusos, explorações, os conflitos entre setores da sociedade, enfim, as contradições e problemas vividos no medievo.

Por outro lado, elementos associados a setores mais progressistas e ligados a causas sociais, ou propriamente de esquerda, por vezes, trazem a imagem de uma Idade Média que seria o perfeito 
contraponto, espelho negativo, dos tempos modernos e atuais. Ou seja, nesta visão oposta, a Idade Média foi um período da humanidade que só vivenciou desgraças e trevas, um período de cerca de mil anos em que pessoas não teriam criado, inovado e lutado (esquece-se de que na Idade Média tivemos a criação das universidades, que técnicas monetárias essenciais hoje tiveram seu advento inicial no período medieval - como as letras de câmbio e cartas de crédito -, que lutas sociais foram travadas, que o grande período de queima das bruxas foi o que se chamou de Idade Moderna, e não Média, entre tantas outras questões) (ECO, 2010/11).

Como afirmou Jerôme Baschet: "A Idade Média não é nem o buraco negro da história ocidental nem o paraíso perdido. É preciso renunciar ao mito tenebroso tanto quanto ao conto de fadas" (2006, p. 24). A Idade Média precisa ser problematizada como um período histórico enquadrado em uma cronologia artificial e parcial, como todo e qualquer outro período histórico que denominamos. E que, como todos os outros (Antiguidade, Modernidade, Contemporaneidade), também possui seus aspectos inovadores, criadores, solidários, suas limitações, seus problemas e contradições.

Podemos dizer que a Idade Média é a cronologia histórica que tem tido mais usos atualmente, seja em apropriações da indústria cultural para entretenimento e consumo (jogos eletrônicos e de tabuleiro, séries, filmes, festas locais, etc.), seja para usos políticos em um século XXI marcado pela produção e disseminação fake news e o cenário da pós-verdade, que questiona a pesquisa científica. Em vista desse cenário, mais do que nunca, a pesquisa e o ensino de Idade 
Média precisam ser trabalhados, tendo em vista a sua recepção e reprodução na esfera pública na atualidade. ${ }^{90}$

Em nossa proposta de Escape Room Medieval buscamos agregar esse contexto temporal que tanto interesse tem motivado em muitas crianças e jovens, principalmente no mundo do entretenimento. Tal contexto que circula, permeado de sensos comuns e informações equivocadas, sem base histórico-científica nas mídias e redes em geral, e que nossos estudantes recebem. Um contexto que precisa, portanto, ser compreendido como um tempo histórico permeado por diversas dimensões (social, cultural, política, econômica) para além de suas classificações positivas e negativas, pois suas bases conhecidas pelos medievalistas acadêmicos continuam desconhecidas pelo público em geral (BIRRO; BOY, 2020, p. 6). Pior que isso, chegam a esse público distorcidas, muito diferentes da compreensão historiográfica tida pelos pesquisadores.

Os estudos do chamado medievalism (medievalismo ou neomedievalismo) são uma alternativa para desvendar e problematizar esses usos e abusos da Idade Média no mundo de hoje (ALTSCHUL; GRZYBOWSKI, 2020; BIRRO; BOY, 2020). Essa área se propõe justamente a pesquisar a recepção do período medieval na contemporaneidade, tendo em vista o grande interesse público, bem como as imagens criadas a respeito do que teria sido o mundo medieval. Desse modo, professores e pesquisadores de História precisam atentar para essas discussões teórico-metodológicas, bem como enfrentar os imaginários de longa duração a respeito da Idade Média, assim como a problemática de seus usos e apropriações recentes. Devemos propor formas de dialogar de modo mais efetivo com alunos e sociedade em geral, tendo em vista a concorrência

\footnotetext{
90 Para verificar mais questões a respeito dessa problematização, conferir as seguintes publicações recentes: (BIRRO; BOY; et al, 2020); (BIRRO; BUENO, 2019); (GRZYBOWSKI; ALTSCHUL; et al, 2020).
} 
desleal que enfrentamos quando se trata da criação de imagens sobre o medievo, no que tange a formas de veiculação, apelos de linguagem e compreensão do que o público em geral deseja consumir no momento (BIRRO, 2020, p. 179).

O Escape Room Medieval que apresentamos aqui busca, portanto, trazer elementos da discussão historiográfica recente sobre a Idade Média, alinhada às abordagens sociais e culturais que foram agregadas à nova proposta curricular brasileira, preocupando-se com a adaptação de meio, linguagem e forma com a quais essas questões serão apresentadas aos jovens estudantes em sala de aula. Trata-se de uma proposta lúdica, que ainda se encontra em desenvolvimento. Pretendemos adiante aplicar o jogo em uma realidade escolar, bem como analisar os dados resultantes dessa futura aplicação.

\section{REFERÊNCIAS}

ALTSCHUL; N. R.; GRZYBOWSKI, L. G.. Em Busca dos Dragões: a Idade Média no Brasil. In: Antíteses, Londrina, v.13, n. 25, p. -35 jan.-jun. 2020. Disponível em: <http://www.uel.br/revistas/uel/index.php/antiteses/article/view/42304> . Acesso em: 20 jan. 2021. ALMALVI, C.. Idade Média. In: LE GOFF, J; SCHMITT, J. C. (Orgs.). Dicionário Temático do Ocidente Medieval. 2v. Bauru, SP: EDUSC, 2002. v. 1.

ALVES, F.. Gamification: como criar experiências de aprendizagem engajadoras. São Paulo: DVS, 2015. ANTONI, E. ZALLA, J.. O que o jogo ensina: prática de construção e avaliação de aprendizado em história. In: GIACOMONI, M. P.; PEREIRA, N. M. (Org.). Jogos e ensino de História. Porto Alegre: Evangraf, 2013.

BASCHET, J.. Introdução: Por que se interessar pela Europa Medieval? In: BASCHET, J. A Civilização Feudal: Do ano mil à colonização da América. São Paulo: Globo, 2006. p. x-y.

BRASIL. Base Nacional Comum Curricular. Ministério da Educação. Secretaria da Educação Básica. Brasília/DF: 2017/18.

BRASIL. Parâmetros Curriculares Nacionais: história Secretaria de Educação Fundamental.. Brasília: MEC/SEF, 1998.

BIRRO, R. M.. Ensino de História Medieval, eurocentrismo e BNCC (2015-2018): um debate recente? In: BUENO, A.; BIRRO, R.; BOY, R. (Orgs.). Ensino de História Medieval e história Pública. 1. ed. Rio de Janeiro: Sobre Ontens/ Editora UERJ, 2020.

BOY, R. V.; BIRRO, R. M. Ensino de História Medieval e História Pública: desafios atuais em formato de apresentação. In: BUENO, A.; BIRRO, R.; BOY, R. (Orgs.). Ensino de História Medieval e história Pública. 1. ed. Rio de Janeiro: Sobre Ontens/Editora UERJ, $2020 .$.

CAMPOS, L. de; LANGER, J.. A História antiga e medieval nos livros didáticos: Uma avaliação geral. In: História e-história, 04 maio 2007. Disponível em:

<http://www.historiaehistoria.com.br/materia.cfm?tb=historiadores\&id=43\#_edn23>._Acesso em: 15 jun. 2016.

CARISSIMI, L. B.; RADÜNZ, R.. Arquivo 7.0: jogos e o ensino de História. In: Métis: história \& cultura, Caxias do Sul, v. 16, n. 31, p.47-69, 2017.

CAROLEI, P.; BRUNO, G. S.; EVANGELHISTA, H.. Framework para Escapes. In: PBL for the next generation - Blanding active learning, technology and social justice. Santa Clara. Anais. Santa Clara: Santa Clara University, 2018. 1-13. 
CARVALHO, C. V.. Aprendizagem baseada em jogos. In. Word Congress on Systems Engineering and Information Technology, 2, 2015, Vigo. Anais... Vigo: COPEC, 2015. p.176-181.

CASTELLS, M.. A Sociedade em Rede. São Paulo: Paz e Terra, 2000.

ECO, U. (Org.). Idade Média, Bárbaros, cristãos e muçulmanos. Milão/Alfragide: Encyclopedia Publishers/Publicações Dom Quixote, 2010/11. v. I.

COSER, M. C.. Um novo conceito de Idade Média nas escolas. In: Representações, Poder e Práticas Discursivas. Seropédica: Editora Universitária UFRRJ, 2010. Disponível em: <www.ufrrj.br/graduacao/prodocencia/publicacoes/praticas-discursivas/artigos/novo.pdf >. Acesso em: 20 jan. 2021.

HUIZINGA, J.. Homo Ludens. São Paulo: Perspectiva, 2000.

KAPP, K. M.. The Gamification of Learning and Instruction. Alexandria: ASTD, 2012.

KARSENTY, T.. Impacto das TIC (Tecnologias de Informação e Comunicação) sobre a atitude, a motivação e a mudança nas práticas pedagógicas dos futuros professores. In: TARDIF, M.; LESSARD, C. (Orgs.). 0 ofício de professor: história, perspectivas e desafios internacionais. 6. ed. Petrópolis: Vozes, 2020. p. 181-199.

LESSARD, C.; TARDIF, M.. As transformações aturais do ensino: três cenários possíveis na evolução da profissão de professor? In: LESSARD, C.; TARDIF, M. (Orgs.). O ofício do professor: história, perspectivas e desafios internacionais. 6. ed. Petrópolis: Vozes, 2020. p. 255-278.

LIMA, D. M. X. de. Uma História Contestada: A História Medieval na Base Nacional Comum Curricular (2015-2017). In: Anos 90, n. 26, p.1-21, 2019.

MACEDO, J. R.. Repensando a Idade Média no ensino de História. In: KARNAL, L. (Org.). História na sala de aula: conceitos, práticas e propostas. 6. ed. São Paulo: Contexto, 2015.

MENDONÇA, H. A.. Construção de jogos e uso de realidade aumentada em espaços de criação digital na educação básica. In: BACICH, L.; MORAN, J. (Orgs.). Metodologias ativas para uma educação inovadora: uma abordagem teórica-prática. Porto Alegre: Penso, 2018. p. 106-128.

MENEZES NETO, G. M. de. História Medieval no ensino fundamental: relato de experiência em uma escola pública do distrito de Mosqueiro (Pará - Brasil). In: Revista de História da UEG, Anápolis, v.4, n.2, p. 320-339, ago.-dez. 2015.

NADAI, E.. O ensino de História no Brasil: trajetória e perspectiva. In: Revista Brasileira de História, São Paulo, v. 13, n. 25/26, set. 1992-ago. 1993, p. 143-162.

PACHÁ, P.. Deus vult: uma velha expressão na boca da extrema direita. In: Agência Pública, 30 abr. 2019. Disponível em: <https://apublica.org/2019/04/deus-vult-uma-velha-expressao-na-boca-daextrema-direita/ >. Acesso em: 20 set. 2019.

PRENSKY, M.. Aprendizagem Baseada em Jogos Digitais. São Paulo: Senac, 2012

SENA, S. et al. Aprendizagem baseada em jogos digitais: a contribuição dos jogos epistêmicos na geração de novos conhecimentos. In: Revista Renote, Porto Alegre, v. 14, n. 1, p. 1-11, 2016.

WIEMKER, M. ELUMIR; E; CLARE, A.. Escape Room Games: "Can you transform an unpleasant situation into a pleasant one?". In: Game Based Learning, s/e: s/l, 2015. 


\title{
MARIA VAI COM AS OUTRAS: AS REPRESENTAÇÕES DA VIOLÊNCIA MIMÉTICA EM UM CONTO DE CONCEIÇÃO EVARISTO
}

\author{
Thays Carvalho Cesar ${ }^{91}$
}

Resumo: Mimesis é um termo de origem grega que significa a faculdade do homem de reproduzir, imitar. Para o historiador René Girard, o desejo é mimético. Sendo assim, homens e mulheres aprendem uns com os outros o que devem buscar. A mimesis leva a uma convergência de anseios sobre um mesmo objeto. $O$ presente artigo tem por objetivo analisar o conto "MARIA", de Conceição Evaristo, à luz da teoria mimética, desenvolvida por René Girard e elencar os estereótipos que levam à prática da chamada Violência Mimética, que surge no conto em forma de linchamento. Na análise em questão, estarão presentes as visões teóricas de René Girard e Stuart Hall, que respaldará a construção dos estereótipos. Sabe-se que a realidade de uma obra literária é ficcional, mas essa ficção, de certa forma, é oriunda de uma realidade. No caso do conto analisado, uma realidade que está circunscrita a todos nós, Marias, Josés e tantos outros nominados e inominados.

Palavras- chave: Mimesis. Escrevivência. Violência mimética.

\footnotetext{
${ }^{91}$ Currículo Lattes: http://lattes.cnpq.br/8335903315687357.
} 


\section{Introdução}

Maria da Conceição Evaristo de Brito, ou simplesmente Conceição Evaristo, nasceu em uma favela na zona sul de Belo Horizonte e teve que conciliar seus estudos com seu trabalho como empregada doméstica até concluir o curso Normal. Aos 25 anos, mudou-se para o Rio de Janeiro, onde passou a lecionar. Evaristo é graduada em Letras pela Universidade Federal do Rio de Janeiro (UFRJ), mestre em Literatura Brasileira pela PUC - Rio e doutora em Literatura Comparada pela Universidade Federal Fluminense (UFF).

Sem falsos sentimentalismos, mas incorporando uma forma de narrar poética à fiç̧ão, os contos de Conceição Evaristo apresentam ao leitor uma significativa galeria de mulheres que, representadas pela autora, simbolizam milhões de mulheres brasileiras, que dançam todos os dias "na corda bamba do tempo" de uma sociedade excludente.

O processo de criação ficcional dos contos de Evaristo é marcado pela construção de personagens e situações que misturam escrita e vivência. Para Marilei Castro Tondo, a escrita de Conceição Evaristo "é feita como um ato de luta, recusando o silêncio e confrontando a cultura dominante, que minimiza as diversas formas de violência sofridas por mulheres" (2018 p.18). Em sua obra, ela concede às pessoas negras que sofreram e ainda sofrem com o silenciamento decorrente dos anos de escravidão, um espaço para falarem de si, de suas lutas e mazelas.

Evaristo torna visível o invisibilizado e, com sua escrita sensível, permite a ressignificação das experiências de dor e sofrimento que estão presentes na vida de suas personagens. É essa identificação com o "outro" que servirá como base para a "escrevivência" da autora, para quem a escrita nasce do cotidiano, das lembranças, da sua experiência de vida e do seu povo e que "não pode ser lida como histórias para 
"ninar os da casa grande" e sim para incomodá-los em seus sonos injustos" (EVARISTO, 2007 p.19).

Para Constância Lima Duarte (2014), a "escrevivência" de Conceição Evaristo tem "a força de um soco", pois ela carrega em seu texto um olhar poético sobre a experiência da subalternidade capaz de articular a "ficção-verdade" com um toque lírico. Para ela, os contos "só confirmam a coerência da opção estética da escritora que, mesmo em cenas de extrema degradação humana não perde o equilíbrio entre a sugestão de estados líricos e a intenção documental" (2014, p. 190). Duarte ainda diz: "escrever a existência" implica o desafio de "transcender o biográfico", desafio que "está na base" de uma escrita "comprometida com a história coletiva" (2014 p. 197). Em outras palavras, é a tradução textual de uma história que pode ser individual ou comunitária.

Assim, Evaristo utiliza a escrita como uma forma de colocar a realidade em diferentes perspectivas, sem abandonar 0 aspecto poético, que pode ser encontrado mesmo nas cenas de maior degradação.

O conto que será analisado neste artigo compõe o corpus do livro Olhos d'água, publicado em 2016, e leva o nome de sua personagem principal: Maria, um nome muito importante para a construção da narrativa. O nome, que pode designar qualquer e todas as mulheres, denota uma diferença indiferenciada que pode ser uma forma de construir um processo estereotípico. Maria é a única personagem nominada no conto. Contudo, sua alcunha carrega uma ausência de especificidade e, ao mesmo tempo, uma configuração social.

Segundo Luis Alberto Santos e Silvana Oliveira:

Nas sociedades primitivas, não existe a noção de pessoa como entendemos hoje. Os seres ocupam lugares sociais, desempenham papeis que são herdados de geração para geração. É possível, por exemplo, que alguém venha a receber exatamente o mesmo nome de um antepassado - não há ideia 
do nome como marca individual intransferível. Ocupa-se um nome do mesmo modo como se ocupa uma função no grupo a que se pertence. (SANTOS; OLIVEIRA, 2001, p. 22)

Atualmente, como herança do Cristianismo, atribuiu-se à ideia de pessoa uma dimensão espiritual. Os seres passaram a ser vistos como humanos e como resultado desta humanidade advém uma carga de sentimentos e ações inerentes a cada pessoa. Ainda como herança do Cristianismo, o nome Maria adquiriu vários significados: mítico, simbólico ou estereotípico. Uma, que pode ser a mãe de Cristo, é um exemplo de vida e devoção para os católicos, enquanto a outra, a Madalena, é apresentada nos evangelhos cristãos como profana. A dualidade entre a mãe devotada e a mulher profana também está presente no conto.

A autora constrói uma personagem que passa de zelosa e preocupada com seus filhos, a profana, como se pode ver nas duas passagens a seguir:

Precisava comprar xarope e aquele remedinho de desentupir nariz. Daria para comprar também uma lata de Toddy. As frutas estavam ótimas e havia melão. As crianças nunca tinham comido melão. Será que os meninos iriam gostar de melão? (EVARISTO, 2016 p.39)

Aquela puta, aquela negra safada estava com os ladrões! (EVARISTO, 2016 p.42)

Essa transição é feita a partir da perspectiva de um narrador onisciente neutro, que observa à distância e usa discurso indireto para caracterizar as personagens. Temos um narrador externo, que não participa dos fatos apresentados, que nos apresenta uma caracterização sumária e alusiva, em discurso indireto, com um distanciamento dos fatos narrados, quase como se estivéssemos lendo uma notícia de jornal.

A caracterização genérica da personagem faz de Maria uma qualquer, apenas mais uma mulher, sem aspectos que a diferenciem, 
que a destaquem dos demais. É só mais uma (ou menos uma) mulher negra, pobre, periférica, que trabalha de doméstica e que teve filhos de deitadas repentinas com homens que a abandonaram. A caracterização alusiva diz muito da pobreza, ou, como Heloísa Toller Gomes destaca no prefácio de Olhos d' Água, da "mulher destituída, vivendo o limite do ser-que-não-pode-ser, inferiorizada, apequenada, violentada" (2016 p.9).

Levando em conta a "escrevivência" da autora, a forma de construir as personagens pode ser um reflexo da nossa sociedade e da forma como as pessoas se relacionam entre as camadas sociais. De acordo Luis Alberto Santos e Silvana Oliveira, a ideia de pessoa é uma construção social, e, portanto, varia historicamente, manifestando-se de modo distinto em cada sociedade:

"A ideia de pessoa depende, portanto, de um imaginário social.
Se cada sociedade veicula uma ideia diferente de pessoa, é de
se esperar que tal diversidade se expresse nos textos que as
sociedades produzem. Em função disso, encontramos, nos
textos literários de cada época e cultura, variações nos modos
de conceber e de articular os sujeitos ficcionais" (SANTOS;
OLIVEIRA, 2001, p. 24)

Ao falarmos de narrador ou de personagens ficcionais, acabamos por tomar como base a ideia de pessoa humana. Segundo SANTOS e OLIVEIRA, uma personagem de ficção pode parecer mais ou menos convincente, mais ou menos semelhante aos seres que encontramos no mundo real (2001 p. 24). Isso indica que tendemos a percebê-la utilizando como molde a nossa concepção de pessoa. Nesse sentido, é possível falar em dois tipos de caracterização de personagens: social e psicológica.

Sobre a caracterização social da personagem, há uma alusão à profissão feita de maneira indireta, exposta no trecho: "havia tido festa na casa da patroa. Ela levava para casa os restos" (EVARISTO, 2016 
p. 39). Esta referência leva o leitor a acreditar que a personagem trabalhava como empregada doméstica. A condição de moradora de periferia também é feita de modo indireto, mediante comentário sobre a vida da personagem e do homem no barraco, o aumento do preço da passagem, o interesse pelo osso do pernil (algo dispensável) e, também, o modo como racionaliza o uso da gorjeta recebida.

Sobre a caracterização psicológica, ela se insinua, em discurso indireto livre, quando do encontro com "o homem", no ônibus. Nesse momento temos acesso à mulher Maria, a fragmentos da vivência de uma mulher usada, abandonada, magoada, sozinha, que almeja dar outra vida para seus filhos. A síntese do que "o homem dizia"92 parece descrever a vida de Maria, uma trajetória de dor, prazer, alegria, devoção aos filhos, despedida e morte. A afirmação de que o corte da "faca à laser corta a vida" marca todo o conto. A lembrança do corte serve para devolver Maria à realidade após momentos de lembranças. A afirmação surge em momentos chave, como ao pensar nos filhos e ao final do conto, na cena derradeira, após o linchamento.

A leitura do conto permite uma série de reflexões, dentre as quais destacamos algumas que serão trabalhadas adiante. Demonstrar o porquê da escolha de Maria e o que a colocou na posição de alvo a partir das teorias de René Girard e Stuart Hall é o que se pretende com este artigo.

\footnotetext{
92 "E o menino, Maria? Como vai o menino? cochichou o homem. Sabe que sinto falta de vocês? Tenho um buraco no peito, tamanha a saudade! Tou sozinho! Não arrumei, não quis mais ninguém. Você já teve outros... outros filhos? A mulher baixou os olhos como que pedindo perdão. É. Ela teve mais dois filhos, mas não tinha ninguém também. Ficava, apenas de vez em quando, com um ou outro homem. Era tão difícil ficar sozinha! E dessas deitadas repentinas, loucas, surgiram os dois filhos menores. E veja só, homens também! Homens também? Eles haveriam de ter outra vida. Com eles tudo haveria de ser diferente. Maria, não te esqueci! Tá tudo aqui no buraco do peito...

O homem falava, mas continuava estático, preso, fixo no banco. Cochichava com Maria as palavras, sem, entretanto, virar para o lado dela. Ela sabia o que o homem dizia. Ele estava dizendo de dor, de prazer, de alegria, de filho, de vida, de morte, de despedida. Do burraco-saudade no peito dele... Desta vez ele cochichou um pouquinho mais alto. Ela, ainda sem ouvir direito, adivinhou a fala dele: um abraço, um beijo, um carinho no filho. E logo após, levantou rápido sacando a arma (EVARISTO, 2016 p. 40).
} 


\section{"Hoje é dia de Maria" - Uma leitura sobre a violência mimética.}

Segundo o historiador e antropólogo René Girard, o "mecanismo de bode expiatório" é a matriz da civilização por meio da qual se dá a canalização da violência grupal contra uma única vítima. (1995 p. 23)

Este mecanismo foi a primeira forma de reestruturação da ordem nas comunidades primitivas, que eram constantemente abaladas por "ciclos de vingança". Devido à inexistência de um sistema judiciário destinado à contenção da violência, as pessoas reconciliavam-se por meio do assassinato de um dos membros da comunidade, escolhido com base em critérios subjetivos.

Ainda de acordo com o historiador, as pessoas escolhem seus objetos de desejo por imitação. Tendo em vista que a cobiça de uns pode ser imitada por outros, uma vontade individual pode se tornar mimeticamente coletiva. Dessa forma, quando duas pessoas passam a desejar o mesmo objeto, é possível que haja um conflito, pois, uma pessoa se torna um obstáculo à conquista da outra. $O$ desejo mimético se torna mais forte na proporção em que o objetivo se torna mais inatingível. Nesse momento, o objeto de desejo deixa de ser lembrado e permanece a reciprocidade negativa que foi gerada por ele.

O desejo mimético gera uma crise, chamada de indiferenciadora. A crise recebe esse nome por indiferenciar os membros da sociedade. Em uma sociedade em crise, todos são iguais e expostos às mesmas situações. No auge desses momentos turbulentos, o desejo reprimido de violência aceita "vítimas substitutivas" para descarregar sua energia.

Ao trazermos a teoria para a realidade encenada no conto, podese imaginar a crise instaurada pelo medo e pelo assalto ao coletivo. Ao suporem uma identificação de Maria com os assaltantes, as vítimas do assalto decidem agredi-la. Nesse momento, Maria é escolhida como bode expiatório, a fim de canalizar a violência sofrida por aquela 
comunidade. O gesto é simbólico e, para os agressores, é como expurgar a violação sofrida com a perda de seus pertences utilizando mais violência.

\begin{abstract}
Os assaltantes desceram rápido. Maria olhou saudosa e desesperada para o primeiro. Foi quando uma voz acordou a coragem dos demais. Alguém gritou que aquela puta safada lá da frente conhecia os assaltantes. Maria se assustou. Ela não conhecia assaltante algum. Conhecia o pai de seu primeiro filho. Conhecia o homem que tinha sido dela e que ela ainda amava tanto. (EVARISTO, 2016, p. 41)
\end{abstract}

Nota-se na citação acima, que uma voz chamou a atenção dos demais para o fato de que Maria poderia estar com os assaltantes. A simples suposição do fato bastou para gerar um momento de caos. Ao final do momento de conflito, uma multidão restou polarizada contra uma única pessoa.

Quando um grupo se une para perseguir a mesma vítima pode saciar, ainda que temporariamente, seus impulsos acumulados, encontrando um motivo "legítimo" para justificar a violência. Segundo Girard, a canalização da violência ocorre pela imolação ou pela expulsão da pessoa que, de repente, tornou-se aos olhos de todos culpada de um mal. (2004 p. 23). Maria, nesse sentido, foi escolhida pelos que estavam no coletivo como o bode expiatório, aquela cujo sacrifício serviria para expiar o mal que se instaurou na comunidade.

Vale destacar que uma das características relevantes na escolha do bode expiatório é a vulnerabilidade do imolado, pois, para que o ciclo de violência seja interrompido, não deve existir pessoa disposta a vingar a morte da vítima.

A personagem foi apresentada no conto como uma mulher solitária, mãe de três filhos. O pai do mais velho era um dos assaltantes do ônibus. As outras crianças foram geradas após "deitadas repentinas com outros homens". Maria não tinha nada além de seus filhos, e sua situação de vulnerabilidade a enquadrou no mecanismo vitimário. 
É importante para o sucesso do mecanismo vitimário que cada membro da multidão acredite que o bode expiatório é culpado. 0 consenso quanto à culpa da vítima a torna diferenciada em meio aos sujeitos indiferenciados. Assim, sozinha e isolada, ninguém poderá interceder a seu favor, pois todos estarão unidos contra uma única pessoa.

No conto, as vozes que tentaram interceder em favor de Maria foram subitamente silenciadas pelos gritos de uma multidão enfurecida. Não havia quem pudesse deter a turba. Maria foi linchada e seu corpo, pisoteado e dilacerado, exposto para proclamar sua condenação.

Ela precisava chegar em casa para transmitir o recado. Estavam todos armados com facas a laser que cortam até a vida. Quando o ônibus esvaziou, quando chegou a polícia, o corpo da mulher estava todo dilacerado, todo pisoteado. (EVARISTO, 2016, p.42)

Os critérios que levam à escolha do bode expiatório serão melhor explorados no item a seguir, no qual serão trabalhados, além do mecanismo vitimário, a construção dos estereótipos.

\section{Maria e os estereótipos da violência}

Uma vez construído o cenário para o surgimento do bode expiatório e delimitada a função desempenhada por esta figura no âmbito social, faz-se necessário identificar os fatores que levam a comunidade a escolher suas vítimas. René Girard elencou algumas condições, denominadas estereótipos persecutórios, que são um conjunto de situações que podem levar à perseguição de uma determinada pessoa.

O primeiro dos estereótipos da classificação de Girard é a existência do que se chama crise indiferenciadora. Este fenômeno 
ocorre quando há uma crise coletiva, que resulta em perseguições. A sensação de medo e de insegurança, por exemplo, pode desencadear uma crise que não escolhe a quem atingir, que indifere as pessoas. $A$ partir do conhecimento desse problema, a sociedade passa a buscar um culpado por ele.

Girard sustenta que, embora sejam certas características do sujeito que acarretam sua escolha como bode expiatório, será mais fácil responsabilizar alguém a quem se atribua um ato amplamente reprovável. Não é necessário que o crime tenha sido de fato praticado, nem que tenha sido cometido por aquela pessoa; na maioria das vezes, uma denúncia mentirosa basta para agitar a multidão. Atribuindo ao sujeito um crime indiferenciador, a acusação ganha credibilidade e concede aos populares a conviç̧ão necessária para julgar e perseguir. Para se enquadrar no segundo estereótipo persecutório, então, a vítima deve ser relacionada a um crime ou ato que seja capaz de provocar reprovação unânime dos membros da comunidade. A esse ato René Girard chama de crime indiferenciador. (2004, p. 25)

No conto fica evidente que Maria é responsabilizada pelo assalto que ocorre no ônibus em que estava: "Negra safada, vai ver que estava de coleio com os dois [...]. Alguém argumentou que ela não tinha descido só para disfarçar. Estava mesmo com os ladrões. Foi a única a não ser assaltada." (EVARISTO, 2014, p. 41-42). Apesar de não haver uma descrição física das demais personagens do conto, nota-se, pela leitura do trecho em questão, que a cor da pele de Maria tem relevância na atribuição de um estereótipo. Ela passa a ser vista como anormal e inaceitável. Além da cor da pele, há outras características atribuídas à personagem sob a forma estereotipada:

No dia anterior, no domingo, havia tido festa na casa da patroa. Ela levava para casa os restos. O osso do pernil e as frutas que tinham enfeitado a mesa. Ganhara as frutas e uma gorjeta. O osso, a patroa ia jogar fora. Estava feliz, apesar do cansaço. A gorjeta chegara numa hora boa. Os dois filhos 
menores estavam muito gripados. Precisava comprar xarope e aquele remedinho de desentupir nariz. Daria para comprar também uma lata de Toddy. (EVARISTO, 2016 p. 39)

De acordo com Stuart Hall, "outra característica da estereotipagem é a sua prática de fechamento e exclusão. Simbolicamente, ela fixa os limites e exclui tudo o que não the pertence" (2016 p. 192). As práticas mencionadas por Hall ficam evidentes ao percebermos a felicidade que tomou conta de Maria ao receber as sobras do jantar ocorrido na casa da patroa. Tanto a estereotipagem atribuída à persoangem pela cor da sua pele, como por sua condição social contribuem para a exclusão social e para a atribuição de marcas vitimárias.

Segundo Stuart Hall, a estereotipagem é parte da manutenção da ordem social e simbólica. Ela estabelece uma fronteira simbólica entre o "normal" e o "pervertido", o "normal" e o "patológico", o "aceitável" e o "inaceitável", o "pertencente" e o que não pertence, entre "pessoas de dentro" (insiders) e "forasteiros" (outsiders), entre nós e eles. (2016 p 192)

As marcas vitimárias são o terceiro estereótipo persecutório apontado por Girard. Elas funcionam como um pressentimento de anormalidade que coloca o bode expiatório à margem do sistema, antes que a ele seja atribuído qualquer ato reprovável. Maria leva a culpa por um crime que não cometeu, apenas por sentar-se ao lado de um dos homens que praticou o assalto. Ainda assim, ela não via no homem um assaltante, mas o pai de seu filho, aquele que the despertava saudades.

Após a ocorrência do assalto, Maria passa a ser vista como inaceitável e diferente dos demais. Afinal, aos olhos daquela comunidade, ela "estava de coleio com os dois". No auge da crise indiferenciadora aquele que melhor se enquadrar nos estereótipos anteriores - crime indiferenciador e marcas vitimárias, 
respectivamente - será o ponto de canalização da violência coletiva. Portanto, Maria se torna um alvo da multidão.

Segundo René Girard, o bode expiatório comunitário substitui todos os inimigos que cada membro do grupo poderia ou gostaria de ter vitimado nos seus conflitos individuais. O comportamento do grupo se mostra, por sua vez, desproporcional à capacidade de defesa do perseguido e tem uma natureza inconsciente. Para o grupo, a vítima é culpada e essa culpa concede uma espécie de salvo conduto para a violência. (1995 p. 91)

Ao adotar a teoria mimética para explicar a violência coletiva é possível dizer que o primeiro agressor encontrará maior dificuldade ao agredir, pois não terá um modelo de conduta a ser seguido. No entanto, após o primeiro golpe, os demais membros do grupo terão a quem imitar. O ciclo da violência mimética se encerra com a morte ou expulsão do bode expiatório.

No conto, o ciclo de violência teve início quando os assaltantes desceram do coletivo, após a constatação, por parte dos presentes, de que Maria não havia sido assaltada como os demais: "Os assaltantes desceram rápido[...]Foi quando uma voz acordou a coragem dos demais. Alguém gritou que aquela puta safada lá da frente conhecia os assaltantes" (EVARISTO, 2016, p. 41).

É importante destacar o trecho "Foi quando uma voz acordou a coragem dos demais" como crucial na abertura do ciclo de violência mimética. Essa voz foi o que deu coragem aos presentes, foi o que, de fato, despertou a comunidade para a violência, talvez acumulada em cada um de seus membros. Adiante, essa mesma voz deixou de ser somente uma voz, mas uma atitude de confronto e um grito de estereotipagem: "A primeira voz, a que acordou a coragem de todos, tornou-se um grito: Aquela puta, aquela negra safada estava com os ladrões! O dono da voz levantou e se encaminhou em direção à Maria" (EVARISTO, 2016, p.42) 
O que fica evidente na adjetivação, "Negra safada", é o preconceito e a criminalização por sua condição de mulher negra. A representação dessa identidade é marcada no conto pela violência e pela submissão. São heranças de um passado de escravidão. Maria não está mais na condição de escrava punida por seu feitor ou pelo capitão do mato, mas está na condição de escrava de sua história de dores, seja pela falta que sente do pai do seu filho, seja pelo peso de the imputarem a culpa por um crime que não cometeu. Maria é humilhada, diminuída, segregada e estereotipada. No processo de estereotipagem é possível estabelecer uma conexão entre representação, diferença e poder. Segundo Hall:

[...] Muitas vezes, pensamos no poder em termos de restrição ou coerção física direta, contudo, também falamos, por exemplo, do poder na representação; poder de marcar, atribuir e classificar; do poder simbólico; do poder da expulsão ritualizada. O poder, ao que parece, tem que ser entendido aqui não apenas em termos de exploração econômica e coerção física, mas também em termos simbólicos ou culturais mais amplos, incluindo o poder de representar alguém ou alguma coisa de certa maneira - dentro de um determinado "regime de representação" (HALL, 2016, p. 193).

A comunidade julgou e condenou Maria: "Alguém argumentou que ela não tinha descido só para disfarçar. Estava mesmo com os ladrões. Foi a única a não ser assaltada." (EVARISTO, 2016, p. 42) e, com o veredito proferido, veio o aval para a pena capital: "Alguém gritou: Lincha! Lincha! Lincha!...". Maria ainda quis falar: "Que merda! Não conhecia assaltante algum. Não devia satisfação a ninguém", mas foi silenciada, como seus antepassados um dia também foram e como tantas outras mulheres ainda são.

Durante $o$ ato de violência, "Maria punha sangue pela boca, pelo nariz e pelos ouvidos, a sacola havia arrebentado e as frutas rolavam pelo chão. Será que os meninos iriam gostar de melão?" (EVARISTO, 2016, p. 42). Ela não saberá a resposta da pergunta, pois foi morta e 
exposta para quem quisesse vê-la, como eram expostos os negros linchados e pendurados às árvores. A violência no corpo de Maria foi um símbolo da humilhação e da consolidação de uma relação de poder. Maria, por sua condição de mulher negra, foi imolada para canalizar a violência coletiva.

Ao contrário das personagens que não possuem caracterização física, as cenas de violência são descritas com riqueza de detalhes. Maria precisava chegar em casa e transmitir o recado do pai ao seu filho, mas foi impedida por aqueles que, "com facas a laser que cortam até a vida", fizeram reviver o açoite e lhe cortaram não só o corpo, mas a alma, a voz e a esperança de viver dias melhores.

\section{Considerações finais: Marias de ontem e de hoje}

Com sua narrativa contundente e precisa, como o corte da "faca com lâmina a laser que corta até a vida", Conceição Evaristo nos faz olhar para Maria e para sua vida, que é pouco ou nada diferente da vida de tantas Marias que conhecemos. Ela, que em sua escrita "ouve gritos, os chamados das vizinhas debruçadas nas janelas, ou nos vãos das portas, contando umas para as outras suas mazelas, assim como suas alegrias" (EVARISTO, 2007, p. 19).

Maria foi uma vítima, não só dos algozes que a assassinaram, mas das saudades que sentia do seu amor, da pobreza e de um sistema que desfavorece aquelas mulheres que estão na base da pirâmide social.

O caminho da narrativa de Evaristo nos leva à dor, ao ímpeto de gritar em favor daquela que não teve defesa. Faz de nós, leitores, espectadores de uma tragédia que não deveria ser comum e, ao terminarmos de ler, estamos nus, despidos de todas as nossas defesas.

O conto evidencia que cabe às Marias de nossa sociedade carregar o fardo da escravidão, da marginalização e da criminalidade 
que marca seus corpos, por meio da violência mimética. Contudo, ainda que traga luz aos temas polêmicos e perturbadores, esta literatura é um espaço de subversão e resistência, um espaço livre para tratar, sem censura, das violações de diretos humanos.

A genialidade de Evaristo reside justamente em, a cada linha, penetrar as camadas emocionais de seus leitores e usá-las para construir suas personagens, reais, profundas e envoltas em uma linguagem poética. Será possível ver poesia nas cenas mais atrozes? A autora nos mostra que sim!

A literatura nos ajuda a refletir sobre nosso lugar no mundo e, mais ainda, sobre o lugar do outro, que deve ser olhado com alteridade e empatia. Ajuda-nos a enxergar a realidade através das linhas e dos espaços de exclusão e de poder. Permite-nos, sobretudo, lançar um olhar crítico para o cânone literário, no qual figuram majoritariamente autores e personagens brancos.

\section{REFERÊNCIAS}

CEIA, C.. Mímesis ou Mímese. In: E - dicionário de termos literários. Disponível em: <https://edtl.fcsh.unl.pt/encyclopedia/mimesis-mimese/>. Acesso em: 18 fev. 2021.

DUARTE, C. L.. Marcas da violência no corpo literário de Conceição Evaristo. In: OLIVEIRA, M. P.; PEREIRA, M. M. S. P.; CARRASCOSA, Denise (Org.). Cartografias da subalternidade: diálogos no eixo sul-sul. Salvador: EDUFBA, 2014.

EVARISTO, C.. Da grafia-desenho de minha mãe, um dos lugares de nascimento de minha escrita. In: ALEXANDRE, M. A. (Org.). Representações performáticas brasileiras: teorias, práticas e suas interfaces. Belo Horizonte: Mazza, 2007

EVARISTO, C.. Olhos d'água. Rio de Janeiro: Pallas/Fundação Biblioteca Nacional, 2016.

GIRARD, R.. O bode expiatório. Tradução Ivo Storniolo. São Paulo: Paulus, 2004.

GIRARD, R.. A rota antiga dos homens perversos. Tradução Tiago José Risi Leme. São Paulo: Paulus, 2009.

GIRARD, R.. La violência y lo sagrado. Barcelona: Editorial Anagrama, 1995.

HALL, S.. Cultura e representação. Rio de Janeiro: Ed PUC-Rio: Apicuri, 2016.

KIRWAN, M.. Teoria Mimética: Conceitos fundamentais. São Paulo: É Realizações, 2015.

SANTOS, L. A. B.; OLIVEIRA, S. P. de. Sujeito Tempo e Espaco Ficcionais: Introdução à teoria da literatura. São Paulo: Martins Fontes, 2001.

TONDO, M. C.. A violência contra as personagens femininas nos contos de Olhos d'água da escritora afro-brasileira Conceição Evaristo. 2018. 99 p (Dissertação de Mestrado em Letras). Programa de Pós-Graduação em Letras, Universidade Tecnológica Federal do Paraná, Pato Branco, 2018. 


\title{
AVALIAÇÃO NA GAMIFICAÇÃO: UM DIÁLOGO NECESSÁRIO
}

\author{
Renan da Cruz Padilha Soares ${ }^{93}$ \\ Anne Carolina Faria Lima94
}

Resumo: O nascimento em uma sociedade densamente tecnológica e a exposição contínua às tecnologias digitais de informação e comunicação fez surgir uma geração de jovens que lidam com a informação de maneira completamente nova. Esses jovens são caracterizados pela agilidade em buscar informações, a capacidade de executar múltiplas tarefas e a habilidade de desenvolver um comportamento não-linear. Esses novos cidadãos desenvolveram novos modos de pensar, relacionar-se com o mundo e aprender. Por isso, a escola tem sido estimulada a ajustar suas práticas, métodos e metodologias a essa nova geração. Nesse artigo é apresentada a proposta de avaliar os possíveis benefícios da adoção de uma prática gamificada e a forma de avaliar os estudantes dentro dessa dinâmica. O trabalho foi feito a partir de uma pesquisa bibliográfica com análise qualitativa. O objetivo é analisar as especificidades da avaliação dentro de um sistema gamificado, a partir de diversas situações práticas vivenciadas pelos educadores.

Palavras-chave: Avaliação. Gamificação. Ensino. História.

\section{Introdução}

As sociedades humanas estão em constante mudança, desde sempre, e essas mudanças são impulsionadas, também, pelas novas

\footnotetext{
${ }_{93}$ Currículo Lattes: http://lattes.cnpq.br/6341626371059889.

${ }^{94}$ Currículo Lattes: http://lattes.cnpq.br/6881587878405681.
} 
tecnologias que surgem. Tais transformações modificam inclusive a forma como as pessoas aprendem os ensinamentos para a vida em sociedade. Isso ocorreu em diferentes tempos e localidades. Porém, é inegável que as transformações que vivemos nos últimos anos, impulsionadas pelo acelerado avanço das Tecnologias de Informação e Comunicação, as TICs, fazem com que a velocidade das mudanças seja cada vez mais rápida. E, como já indicamos, a maneira de as novas gerações apreenderem os saberes necessários para a vida em sociedade se modifica rapidamente.

Diante desse quadro, a escola é convocada para repensar seus métodos e lidar de forma mais efetiva e eficiente com a nova geração de estudantes. Além disso, um velho e importante desafio é lançado: como avaliar o aprendizado de tal geração, que apreende de forma tão distinta do que uma geração anterior?

Quando pensamos no ensino de História, suas especificidades farão com que essa relação entre novas formas de aprender e a necessidade de avaliá-las tenha um contorno ainda mais significante. A metodologia tradicional em História, voltada para a memorização de fatos históricos, nomes e datas, persiste arraigada em velhas práticas, principalmente nas escolas de Educação Básica brasileiras. Tal história, descolada da realidade dos estudantes, tem se mostrado cada vez mais incapaz de motivá-los e fazê-los compreender os processos históricos, transformações e permanências.

A avaliação está intimamente relacionada com os métodos utilizados em sala de aula. No ensino de História tradicional, ela também era tradicional, exigindo que o aluno memorizasse uma série de informações, sem que precisasse refletir de alguma forma.

Autores como Luckesi (2000), Noda (2005), Schimidt e Cainelli (2009), apontam para a necessidade de avaliar o processo de ensinoaprendizagem como um todo, e não apenas em momentos estanques. Outra questão importante é a desmitificação do pretenso caráter 
objetivo e imparcial dos exames, compreendendo-os inseridos no meio social em que se encontram e apontando a importância de aspectos subjetivos envolvidos.

Diante desse quadro, surgem novas estratégias para auxiliar o processo de ensino-aprendizagem, dentre elas, as metodologias ativas. Estas metodologias propõem uma abordagem do ensino que coloca o estudante como sujeito ativo do processo de ensinoaprendizagem. Esse objetivo, presente desde as propostas pedagógicas de Paulo Freire, atualmente tem como foco tornar mais eficiente o diálogo com o estudante de hoje e suas novas demandas.

Dentre as metodologias ativas, destacamos a gamificação. Como tal proposta pedagógica pretende criar uma camada de jogo em um ambiente de não-jogo, nesse caso, no processo educativo, tal metodologia está profundamente relacionada com a forma com que as novas gerações lidam com o mundo ao seu redor. Portanto, tais elementos dos jogos têm grande potencial motivador.

Pensando nas características motivadoras da gamificação e na realidade da maioria das instituições de ensino, o presente trabalho analisa a avaliação dentro de um sistema gamificado, propondo alternativas para diferentes situações e problemas. Assim sendo, tem como objetivo analisar as possibilidades avaliativas dentro de um sistema gamificado. Também busca apresentar formas práticas de inovar em sala de aula, evitando as amarras da burocracia. Adicionalmente, discute-se se, dentro do modelo proposto, é possível avaliar o conteúdo de História sem cair nos vícios de um tradicionalismo estéril.

Para isso serão analisadas de maneira qualitativa as bibliografias referentes aos conceitos de ensino de História, metodologias ativas, gamificação e avaliação.

\section{Avaliando em uma proposta gamificada: Metodologia}


Como metodologia, nesta pesquisa utilizamos a revisão bibliográfica e uma análise qualitativa dos dados e informações encontrados na revisão. A pesquisa qualitativa se encaixa neste artigo por sua própria natureza. Surge como superação de uma análise positivista das ciências humanas e a compreensão de que as características desse tipo de ciência se diferiam das características das ciências exatas. Como afirma Triviños:

\begin{abstract}
A ausência de hipóteses rígidas a priori, que deviam ser empiricamente verificadas, apoiando-se, de maneira fundamental, na estatística, obrigou o pesquisador a ter um conhecimento geral aprofundado da realidade que servia de contexto ao foco em estudo e dos suportes teóricos principais que guiavam sua ação. (1987, p. 123)
\end{abstract}

Ou seja, para uma pesquisa qualitativa, é preciso olhar além dos números. É preciso compreender o contexto em que eles. No nosso caso específico, a pesquisa qualitativa precisa compreender a realidade escolar, que, por si só, é muito diversa.

Portanto, ao se debruçar nos estudos sobre avaliação e gamificação, o pesquisador deve entender que a aplicação de uma proposta de atividade levará em conta as enormes diferenças que existem em cada contexto escolar. Para isso, esta pesquisa foi feita nas seguintes etapas, descritas a seguir, e buscando construir um artigo geral, que sirva como base para a adaptação de outros educadores aos seus próprios contextos.

Assim, foi necessário analisar todos os conceitos que envolveriam a proposta feita: ensino de história, avaliação e gamificação, para, ao final, montar uma proposta nova.

A primeira etapa, portanto, buscaram-se dados em autores consagrados do meio, além de teses e dissertações que abordassem os temas citados. Após o levantamento, realizou-se um estudo 
sistemático dos conceitos, separando e destacando as definições e análises que mais se enquadravam nos objetivos da pesquisa.

Tendo feito o estudo qualitativo e aprofundado dos conceitos de avaliação, ensino de história, jogos e gamificação, partiu-se para a etapa de elaboração de uma proposta de avaliação gamificada, que atendesse aos objetivos propostos pelo artigo, ou seja, que fosse capaz de apresentar uma alternativa às avaliações tradicionais, ao mesmo tempo que possibilitasse sua adaptação em diferentes contextos. Criou-se, então, a proposta que utilizou os elementos básicos dos jogos numa avaliação de múltipla escolha.

A última etapa foi, por fim, a construção do texto, encaixando a proposta da atividade prática com a análise teórica feita através do levantamento bibliográfico.

\section{Referencial teórico: Ensino de História}

É importante começamos essa reflexão apontando que partimos do ponto de vista do educador de História, visto que esta é a formação do autor deste artigo. Por isso, as próximas linhas serão dedicadas a pensar um pouco das especificidades do ensino da disciplina. Porém, a proposta aqui apresentada, como ficará claro ao longo do trabalho, tem grande potencial de aplicabilidade em diversos campos distintos do saber.

Ao longo do texto veremos que não há como separar a avaliação do processo de ensino-aprendizagem. Ou seja, antes de pensarmos numa proposta pedagógica para avaliação em História, precisamos pensar em que tipo de ensino de História queremos para a sala de aula. Esse tipo de ensino será decisivo na relação que os estudantes estabelecerão com o conteúdo e com o professor.

A partir da primeira metade do século $X X$, a historiografia assistiu ao surgimento de estudos com novos temas, novos sujeitos e novas 
fontes. Porém, o ensino de História, por muito tempo, permaneceu preso a uma visão tradicional da disciplina. Tal visão valorizava somente uma narrativa eurocêntrica, focada na memorização da história dos grandes homens e seus feitos.

Sua persistência no ensino tradicional tinha uma intencionalidade. Por muito tempo, o ensino de História foi visto como uma forma de governos e seus representantes influenciarem na formação de uma consciência nacional. Astrogildo Júnior e José Sousa afirmam que, nessa linha de pensamento tradicional, o ensino de História servira para "inculcar determinados valores para a preservação da ordem, da obediência à hierarquia, de modo que a Nação pudesse chegar ao progresso, modernizando-se segundo o modelo dos países europeus" (2016, p. 1).

Essa concepção de ensino de História, contudo, fracassa tanto em seu objetivo primário, pois encara os estudantes como receptores passivos dos valores das elites, quanto em estabelecer uma aprendizagem significativa em História. Mattos aponta que o ensino de História tradicional,

[...] na articulação entre passado-presente-futuro, aprisionava não só o futuro, mas também os homens que haviam participado da experiência contada, assim como aprisionava o próprio sujeito que contava uma história, por meio de determinismos diversos. (2006, p. 10)

E como os professores tradicionais de História avaliavam esse conhecimento? O exemplo abaixo (Figura 1), retirado do livro didático de Victor Mussumeci (1968), não traz nenhuma surpresa: 
Figura 1 - Exercícios no Livro Didático de 1968

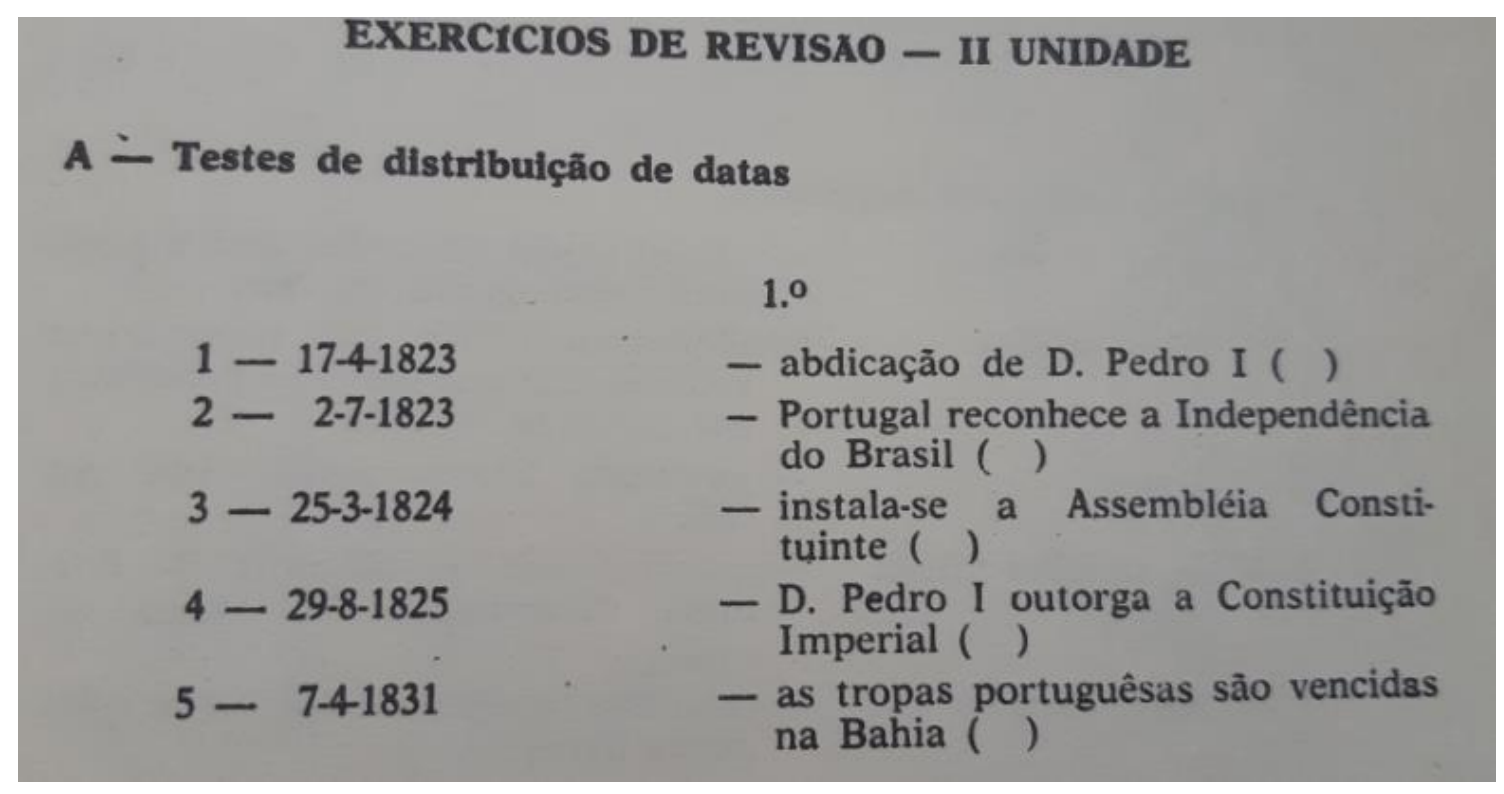

Fonte: MUSSUMECI, Victor. História do Brasil. São Paulo: Editora do Brasil S/A. 1968.

O exercício proposto pelo livro busca analisar se o estudante foi capaz de memorizar, mecanicamente, os fatos históricos com sua data exata. Esse exemplo mostra como a metodologia utilizada em sala se relaciona intimamente com o tipo de avaliação que se propõem (assunto que nos aprofundaremos mais adiante), bem como, com os objetivos pedagógicos gerais compostos no currículo. Basta lembrar que tal livro era aplicado para os estudantes de História durante a Ditadura Civil-Militar brasileira.

Então, o que buscamos quando falamos de uma aprendizagem significativa em História? A historiadora Emília Viotti da Costa há bastante tempo apresenta um pensamento que nos ajudará a refletir sobre o assunto. Para ela:

A História ainda pode também desenvolver o raciocínio indutivo. Educa a imaginação. Formulando problemas, 
analisando os porquês, as razões, as condições que explicam um determinado fenômeno, problemas da sociedade. Enxergar soluções. Mas tudo isto sempre que a História ensinada permaneça num plano explicativo e não se restrinja à fastidiosa enumeração de fatos, dados, nomes, geralmente sem significado, e que são obrigatoriamente decorados pelos alunos. (1957, p. 115)

Mudam-se, então, os objetivos pensados para o ensino de História. Ele deve ser capaz de possibilitar que o estudante se torne reflexivo, capaz de ler e interpretar o mundo ao seu redor a partir da compreensão do processo histórico, transformações e permanências. Laville segue essa linha de pensamento escrevendo que mão podemos

[...] perder de vista a função social geralmente declarada hoje a respeito do ensino da história: formar indivíduos autônomos e críticos e levá-los a desenvolver as capacidades intelectuais e afetivas adequadas, fazendo com que trabalhem conteúdos históricos abertos e variados. (1999, p. 137)

Nas perspectivas modernas do ensino de História a disciplina não mais servirá para memorização de um passado inventado por uma parcela da sociedade. $O$ ensino deve fazer sentido aos estudantes e dialogar com seu presente. Tendo isto em vista, agora será preciso avaliar se esse objetivo foi alcançado.

\section{Avaliação}

"Semana de Provas", "Exames Finais", "Prova Final". Frases simples e que são capazes de gerar fortes emoções nos estudantes aos quais elas são direcionadas. Emoções essas relacionadas, normalmente, a sentimentos de medo, ansiedade e tensão. Tais sentimentos, pelos quais muitos de nós já passamos algum dia, demonstram que o ato de avaliar, na maioria das vezes, é mal utilizado no Brasil. 
Não atoa, é comum presenciar a avaliação sendo utilizada como forma de disciplinar. Luckesi analisa esse aspecto da avaliação escrevendo que:

Podemos utilizar um instrumento de avaliação junto aos nossos educandos, simplesmente, como um recurso de coletar dados sobre suas condutas aprendidas ou podemos utilizar esse mesmo instrumento como recurso de disciplinamento externo e aversivo, através da ameaça da reprovação, da geração do estado de medo, da submissão, e outros. (2000, p. 5)

É para que se proponham formas de romper com esse tipo de utilização da avaliação que escrevemos este artigo. Porém, antes de pensarmos em como avaliar, precisamos nos debruçar, rapidamente, no conceito de avaliação. Como veremos adiante, não podemos confundir avaliação com prova. A avaliação é realizada por todo ser humano cotidianamente, mesmo fora do contexto escolar. Luckesi escreve que:"As avaliações cotidianas e habituais nos permitem fazer escolhas e viver o dia a dia, solucionando nossas necessidades imediatas." (2018, p.26).

Percebam, portanto, que avaliar é muito mais do que uma prova de fim de ciclo. Evidentemente que o sentido que estamos buscando aqui é de uma avaliação programada e consciente, aplicada no contexto escolar. Sendo assim, retorno à Luckesi, que definirá avaliação na educação como o "ato de investigar a qualidade da aprendizagem do estudante, fator que implica em cuidados metodológicos específicos $[\ldots]$ "(2018, p. 77). Com "investigar a qualidade", o autor aponta que o ato avaliativo nada mais é que uma investigação do que foi aprendido pelos estudantes, a partir de um critério de qualidade previamente estabelecido e utilizando planejamento e métodos cuidadosamente pensados. 
Investigada a qualidade do aprendizado dos estudantes é preciso definir o que fazer com os resultados. Luckesi aponta que há dois usos desses resultados, que irão influenciar os tipos de instrumentos avaliativos utilizados em sala. Seus usos são: o "uso seletivo" e o "uso diagnóstico". O uso seletivo tem o objetivo de selecionar o estudante em aprovado e reprovado, além de classificar numa escala do melhor para o pior. Já o "uso diagnóstico" objetiva analisar, no decorrer do processo de ensino, se a qualidade do aprendizado, planejada para aqueles estudantes, está atingindo os objetivos traçados, ou se precisa de reajustes ( 2018, p. 64-65).

Essas definições importam para nosso artigo, pois, as avaliações tradicionais, baseadas no exclusivo "uso seletivo" dos resultados da investigação avaliativa, têm sido predominantes no ensino brasileiro até os dias de hoje. Assim, a avaliação resume-se ao exame escrito, normalmente aplicado ao final de um ciclo e com uma forte carga emocional negativa.

A "semana de provas" torna-se quase um momento ritualístico do sistema escolar, muitas vezes visto como um "sofrimento necessário". Noda aponta que:

\footnotetext{
No sistema brasileiro, a avaliação é tradicional, sendo um dos deveres a serem cumpridos tanto pelos professores como pelos alunos durante o ano letivo, ou no final de cada bimestre, como é o mais comum. E como quase sempre, avaliar representa uma obrigação, um dever a mais a ser realizado, acaba sendo um mecanismo sem fundamento, sem valor [...] perde sua contribuição maior que é demonstrar se os objetivos foram alcançados. (2005, p. 144)
}

Assim, a forma como temos avaliado nossos estudantes reforça um aspecto autoritário do sistema escolar e, efetivamente, não consegue alcançar o objetivo principal, que é analisar se o aprendizado 
está dentro da qualidade planejada e desejada pelo educador. Esse objetivo não é alcançado, pois:

O uso seletivo dos resultados exige que o estudante revele seu desempenho em sua aprendizagem no modo pontual, ou seja, só valem os conhecimentos e habilidades revelados de nodo positivo, aqui e agora, no momento em que os testes e tarefas são realizados. (LUCKESI, 2018, p. 84-85)

Ou seja, tendo em vista a forte carga emocional, já discutida aqui, que possuem esses exames, aquilo que o estudante pode apresentar no momento pontual da realização do teste poderá não ser representativo do que ele de fato aprendeu ao longo do processo de ensino-aprendizagem.

Então, como deveríamos avaliar nossos estudantes e aplicar o chamado "uso diagnóstico" (LUCKESI, 2018) dos resultados da avaliação? Primeiramente, é preciso reafirmar a importância do planejamento. Quando falamos de traçar um objetivo estamos falando, necessariamente, de planejamento. Tendo em vista que a avaliação não pode estar descolada do processo de ensino-aprendizagem como um todo, o planejamento pedagógico é uma das partes do processo que inclui a avaliação. Noda afirma:

Traçar objetivos, pressupõe um planejar por parte do professor. O planejamento nutre-se de reflexões acerca dos conteúdos; dos conceitos; do cotidiano da sala de aula; da contribuição que cada aluno poderá oferecer. (2005, p. 144)

Para investigar se os estudantes estão atingindo a qualidade do aprendizado desejada é preciso ter bem claro quem são eles, qual é o padrão de qualidade desejado, além dos conteúdos que devem ser abordados e o que os estudantes devem extrair deles. Luckesi afirma que: 
Planejar a avaliação da aprendizagem significa, pois, estabelecer o objeto da investigação, com seus conteúdos e variáveis, que, conjuntamente, configuram a abrangência dos dados a serem coletados para a prática avaliativa, assim como os recursos de coleta de dados para a avaliação (2018, pp. $137,138)$.

Avaliar, desse modo, é uma atividade conscientemente planejada para todo o processo de aprendizagem, e não simplesmente um instrumento disciplinador e classificador dos estudantes. É, portanto, parte integrante do processo de ensino-aprendizagem. A utilização do "uso diagnóstico" dos resultados, como indica Luckesi (2018), subsidia o educador a analisar constantemente se seus objetivos estão sendo alcançados, ou se será necessário corrigir os rumos do processo.

Por isso, 0 ato de avaliar não pode ser somente 0 final do processo. Ele é um exercício constante de coleta de dados e investigação da qualidade da aprendizagem dos estudantes, com o objetivo de planejar as ações que devem ser tomadas a partir desses dados.

A coleta de dados está intimamente relacionada com o instrumento de avaliação a ser usado pelo educador. Luckesi aponta que o planejamento da avaliação da aprendizagem incidirá, também, nos instrumentos selecionados para realizar a coleta dos dados. Sobre tais instrumentos, o autor escreve que "só podemos saber se o estudante adquiriu determinado conhecimento ou habilidade à medida que ele manifeste isso por meio de variadas possibilidades de recursos de coleta de dados a respeito de sua aprendizagem" (LUCKESI, 2018, p. 79). Os instrumentos devem ser "adequados para coletar os dados que estamos necessitando para configurar o estado de aprendizagem do nosso educando" (LUCKESI, 2000, p. 4). 
Assim, reafirmamos que o instrumento da avaliação deve coletar os dados que comprovem em que medida nossos alunos estão alcançando os objetivos traçados por nós no planejamento.

Quanto aos objetivos que devem ser traçados por um professor de História no seu planejamento, são aqueles discutidos no tópico anterior e que devem estar refletidos no instrumento avaliativo. Em História, nem sempre isso é alcançado. Noda observa que:

Embora amplamente criticada, a avaliação no ensino de
História tem valorizado muito a memorização; que
pressupõem notas e uma classificação. Encerrando aí o
processo de ensino/aprendizagem, exatamente no momento
em que deveria começar, ou pelo menos prosseguir. (2005, p.
149)

Então, uma pergunta fica lançada: o que uma avaliação em História deve verificar? Nunca será uma pergunta fácil de responder, visto que todo o processo avaliativo, tal como a aprendizagem em História, nunca é simples. Porém, a essa altura do artigo, possuímos alguma base para buscar a resposta. Se estamos falando de um ensino de História que superou os métodos tradicionais, a avaliação em História deve ser capaz de verificar se o aluno foi capaz de "aprender a formular hipóteses; aprender a classificar e analisar fontes; aprender a analisar a credibilidade das fontes históricas; aprender relações de casualidade e a construir explicação histórica" (SCHIMIDT; GARCIA, 2003, p. 203).

Isso nos leva, novamente, ao tipo de instrumento a se utilizar para fazer essa verificação. Sobre os diferentes instrumentos, Noda afirma: "É necessário o conhecimento de cada um deles e utilizá-los em momentos diferentes do processo de ensino" (2005, p. 146). Pensando nisso, a avaliação deverá, necessariamente, ir além da tradicional prova escrita aplicada ao final de um ciclo. É preciso criar múltiplos instrumentos que valorizem as múltiplas formas de se expressar de nossos estudantes. 
A prova escrita valoriza apenas um aspecto da inteligência. Para Gardner, cada ser humano possui "múltiplas inteligências" que modificará sua forma de se expressar. O autor explica que:

\begin{abstract}
A teoria das inteligências múltiplas, por outro lado, pluraliza o conceito tradicional. Uma inteligência implica na capacidade de resolver problemas ou elaborar produtos que são importantes num determinado ambiente ou comunidade cultural. A capacidade de resolver problemas permite à pessoa abordar uma situação em que um objetivo deve ser atingido e localizar a rota adequada para esse objetivo. A criação de um produto cultural é crucial nessa função, na medida em que captura e transmite o conhecimento ou expressa as opiniões ou os sentimentos da pessoa. Os problemas a serem resolvidos variam desde teorias científicas até composições musicais para campanhas políticas de sucesso. (1995, p. 21)
\end{abstract}

Portanto, formas variadas e criativas de avaliação devem ser pensadas. A própria observação ativa do professor faz parte desses múltiplos instrumentos. Noda ressalta que: "Nesta observação que se faz no cotidiano durante as aulas, o professor deve estar atento a aspectos que denominará subjetivos" (2005, p. 146). Ou seja, esses aspectos subjetivos, na maioria das vezes, passam desapercebidos nos instrumentos avaliativos tradicionais.

Neste artigo, estamos trabalhando baseados em que o educador está utilizando uma metodologia gamificada em sua sala de aula. Adiante, debruçar-nos-emos nos estudos sobre gamificação, mas por hora, é importante reafirmamos uma questão: a avaliação está intimamente relacionada com a metodologia adotada pelo educador. Luckesi afirma que o instrumento de coleta de dados deve ser "compatível com aquilo que fora ensinado, em termos de conteúdo, metodologia e prática; nem mais, nem menos que isso" (2018, p. 79).

Essa é uma reflexão de suma importância para nós, pois, que estamos propondo a adoção de uma metodologia de ensino diferenciada. A avaliação dentro dessa metodologia deve ser 
compatível com a dinâmica proposta, sob o risco de não ser efetiva a investigação da qualidade do aprendizado dos estudantes envolvidos.

Mas uma questão ainda persiste: o professor trabalhará, na maioria das vezes, em instituições que estão presas à lógica da necessidade de uma prova escrita ao final de um ciclo. Este trabalho pretende analisar possíveis formas de colocar as reflexões que tivemos sobre a avaliação em prática, mesmo nas mais difíceis e engessadas realidades escolares. Mas antes, precisamos entender o que é a gamificação e de onde vem essa metodologia.

\section{Metodologias ativas}

Gamificação é uma das diversas metodologias diferentes que compõem as chamadas Metodologias Ativas. Por isso, vamos nos debruçar um pouco sobre elas e tentar entender sua proposta e como se relacionam com o ato de avaliar.

Como dissemos, pouco adiantaria eu escolher um instrumento avaliativo moderno, se minha metodologia for arcaica, e o mesmo vale para o inverso. Podemos pensar em ensinar na disciplina de História com uma visão de "História vista de baixo", valorizando a participação de sujeitos historicamente esquecidos, mas, para isso, precisamos trabalhar a partir de metodologias que permitam que o estudante entenda esse conteúdo histórico em sua plenitude, fugindo da tradicional memorização da História dos grandes homens. E precisamos saber como avaliar esse aprendizado feito de forma não tradicional.

Assim, pensar em formas diferenciadas de avaliar, é também pensar em formas diferenciadas de trabalhar os conteúdos. As metodologias ativas se apresentam como uma alternativa nesse processo. Ainda que se tratem de diferentes metodologias, todas 
possuem algumas características similares entre si. Entre essas características, podemos destacar aquela que lhe dá nome: tornar o estudante um sujeito ativo no processo de ensino-aprendizagem.

Nas palavras de Gemignani:

A metodologia ativa é uma concepção educativa que estimula processos construtivos de ação-reflexão-ação (FREIRE, 2006), em que o estudante tem uma postura ativa em relação ao seu aprendizado numa situação prática de experiências, por meio de problemas que lhe sejam desafiantes e lhe permitam pesquisar e descobrir soluções, aplicáveis à realidade. (2012, p. 6)

Ao referenciar Paulo Freire nesta reflexão, o autor evidencia que a ideia de pensar os estudantes como sujeitos ativos no processo de ensino-aprendizagem não é nova. As metodologias ativas, porém, possuem o mérito de trazer as importantes reflexões deitas por Freire, e outros pedagogos do século $X X$, para a complexa realidade do século XXI. José Moran aponta que:

Os métodos tradicionais, [...] faziam sentido quando o acesso à informação era difícil. Com a Internet e a divulgação aberta de muitos cursos e materiais, podemos aprender em qualquer lugar, a qualquer hora e com muitas pessoas diferentes. (2015, p.16)

Ainda nessa linha de raciocínio, Moran aponta que: "A vida é um processo de aprendizagem ativa, de enfrentamento de desafios cada vez mais complexos." (2018, p. 2). Assim, o debate em torno das metodologias ativas dialoga diretamente com o jovem inserido no mundo digital, que modificou sua forma de lidar com a informação e aprender. Esse jovem vive em um mundo em constante transformação e a escola precisa ser instrumento fundamental para prepará-lo para viver nesse ambiente de forma ativa e reflexiva.

Outra característica importante das metodologias ativas, dialoga perfeitamente com a questão apresentada acima. Trata-se da 
contextualização. Essas metodologias possuem a preocupação de relacionar os conteúdos com a vida real dos estudantes. Recorrendo, mais uma vez, a José Moran, ele afirma que: "Nas metodologias ativas de aprendizagem, o aprendizado se dá a partir de problemas e situações reais; os mesmos que os alunos vivenciarão depois na vida profissional, de forma antecipada, durante o curso." (2015, p.16)

A discussão sobre fazer o conteúdo lecionado ser verdadeiramente útil aos estudantes é cara ao ensino de História. Como já debatido, parte essencial de uma nova concepção a respeito do ensino na disciplina histórica refere-se à necessidade de construir ligações entre o conteúdo estudado e o mundo em que o estudante está inserido, permitindo-o não absorver ingenuamente aquilo que lhe é ensinado, mas participar ativamente do processo.

Uma participação ativa e reflexiva dos estudantes exigirá também autonomia, outro foco importante dos estudos que envolvem as metodologias ativas. Borges e Alencar trabalham essa questão quando escrevem que

A utilização dessas metodologias pode favorecer a
autonomia do educando, despertando a curiosidade,
estimulando tomadas de decisões individuais e coletivas,
advindoas das atividades essenciais da prática social e
em contextos do estudante. (2014, p. 120)

Assim, pensar em metodologias ativas para as aulas de História significa planejar e construir um ensino cujo objetivo é propiciar aos estudantes autonomia e reflexão crítica, a partir de uma participação ativa do mesmo em seu aprendizado.

E, conforme já analisamos, para que o aprendizado tenha efetivo sucesso, precisamos saber avaliar corretamente se a qualidade do aprendizado desejado está sendo atingido. Ou seja, precisamos fazer o uso diagnóstico dos dados da avaliação (LUCKESI, 2018), que 
nos municiará das informações necessárias para ajustar a metodologia aplicada e atingir o melhor resultado.

Por isso, a avaliação é parte integrante da metodologia escolhida. Ao pensarmos em trabalhar qualquer tipo de metodologia, é preciso, também, pensar em como avaliar dentro dessa metodologia. Que instrumentos se relacionam melhor com aquela forma que eu escolhi de ensinar e com os conteúdos que estou ensinando.

Portanto, quando escolhemos a gamificação para ensinar História aos nossos alunos, essa é uma preocupação que deve estar sempre presente. Das metodologias ativas, a gamificação encaixa-se perfeitamente no diálogo com os estudantes inseridos em um mundo cada vez mais complexo e digital. Precisamos entender esse mundo e entender como avaliar o aprendizado nesse mundo. Para isso, precisamos entender melhor o que é a gamificação. $O$ que faremos a seguir.

\section{Gamificação}

O nome já indica a base da qual partem os estudos de gamificação: os games. Ou seja, os jogos, principalmente os jogos eletrônicos, que tanto prendem a atenção da maioria dos jovens. Os estudos sobre Aprendizagem Baseada em Jogos e gamificação identificaram que os jogos possuem elementos motivadores, capazes de engajar seus jogadores fazendo-os gastar uma grande quantidade de tempo na atividade. Logo, pensou-se que sua utilização na educação, com esses elementos, poderia ser de grande ajuda.

A gamificação consiste, portanto, em aplicar os elementos motivadores dos jogos em uma atividade de não jogo. Schlemmer define que:"A gamificação se propõe a criar uma camada de jogo numa aplicação ou produto, no lugar de ser, na origem, um jogo." (2014, p. 
77) Já Zichermann e Cunninghan (2011) afirmam que a gamificação é uma prática na qual se utiliza o pensamento e a dinâmica de jogos para engajar pessoas e resolver situações. Ou seja, ambos indicam que, quando gamificamos algo, estamos utilizando os elementos dos jogos em uma atividade comum, com o objetivo de fazer com que essa atividade seja motivadora suficiente para que as pessoas a realizem mais ativamente.

Assim, já fica mais clara a relação da gamificação com as Metodologias Ativas e a sala de aula. Se seus estudos apontam que sua utilização motiva aquele que está inserido em uma dinâmica gamificada a realizar uma tarefa de forma ativa e prazerosa, sua utilização em sala de aula teria muito a acrescentar.

Portanto, estudiosos do assunto perceberam que um jogo não motiva de forma aleatória. Há nele elementos propositalmente pensados para criar diversos tipos de emoções em seus jogadores. Tais elementos são capazes de fazer o jogador dedicar uma grande quantidade de tempo em atingir os objetivos do jogo. No entanto, que elementos são esses?

Flora Alves (2015), a partir dos estudos de Kevin Werbach, apontará diversos desses elementos e, aqui, citaremos alguns: competição e colaboração; estado de vitória; recompensas; doação; avatares; níveis, dentre muitos outros. Ou seja, um planejamento gamificado é aquele que incorporará esses e outros elementos em uma atividade comum do dia a dia. E, é claro, um planejamento gamificado para a educação, incorporará esses elementos nas atividades comuns do cotidiano escolar.

Os estudos sobre a gamificação, no entanto, tiveram início no mundo corporativo e só posteriormente foram apropriados por estudiosos da Educação. Por isso, a incorporação da gamificação para 
o processo de ensino-aprendizagem passa necessariamente por uma ressignificação da metodologia. Isso porque os objetivos traçados por um educador que gamifica sua aula de História são (e devem ser) bem diferentes dos objetivos de um empresário que gamifica seu ambiente de trabalho.

Se a competição é um dos elementos base de diversos jogos e explica grande parte da motivação e engajamentos de seus jogadores, a colaboração é um elemento não menos importante. Schlemmer escreve que:

\begin{abstract}
A gamificação pode ser pensada a partir de pelo menos duas perspectivas: enquanto persuasão, estimulando a competição, tendo um sistema de pontuação, de recompensa, de premiação etc., o que do ponto de vista da educação reforça uma perspectiva epistemológica empirista; e enquanto construção colaborativa e cooperativa, instigada por desafios, missões, descobertas, empoderamento em grupo, o que do ponto de vista da educação nos leva à perspectiva epistemológica interacionista-construtivista-sistêmica." (2014, p. 77)
\end{abstract}

Numa perspectiva gamificada de ensino, o educador deve construir uma metodologia que reforce os aspectos dos jogos condizentes com os objetivos traçados em seu planejamento, conforme já foi exposto. Isso, contudo, não significa que aspectos dos jogos como a competição, as recompensas e as premiações não possam estar presentes, desde que não sejam o foco.

A gamificação do conteúdo a ser trabalhado nas aulas de História permite a aplicação de múltiplos instrumentos avaliativos, que valorizem as múltiplas inteligências, além de permitir ao professor uma observação privilegiada do processo ensino-aprendizagem. Vamos, então, analisar as possibilidades e necessidades da avaliação em um planejamento gamificado 


\section{A avaliação gamificada}

Como já foi dito, a gamificação nada mais é do que a aplicação de elementos dos jogos em uma atividade de não jogo, ou seja, no caso da sala de aula, é aplicação desses elementos nas atividades comuns da escola.

Portanto, avaliar em uma dinâmica gamificada, a princípio, não se difere muito de avaliar em qualquer outra metodologia. É preciso aplicar múltiplos instrumentos, que sejam capazes de colher, da melhor forma possível, uma quantidade de dados suficientes que permita, fazendo o uso diagnóstico desses dados (LUCKESI, 2018), ajustar a metodologia para alcançar o objetivo final, que é o da aprendizagem.

Porém, apontamos que uma dinâmica gamificada poderá facilitar a aplicação de múltiplos instrumentos por suas próprias características. Por exemplo, o primeiro instrumento que recomendamos é a observação ativa. A observação da participação dos alunos deve ser feita de forma metodologicamente pensada e não improvisada. Por isso, propomos o seguinte quadro (Figura 2 ) do que é preciso observar em nossos estudantes. 
Figura 2 - Tabela de observação ativa

\begin{tabular}{|c|c|c|c|c|}
\hline & \multicolumn{4}{|c|}{ Aula 1} \\
\hline Grupo 1 & Presença & Participação oral na aula expositiva & Participação nas tarefas propostas & Colaboração com os colegas \\
\hline \multicolumn{5}{|c|}{ 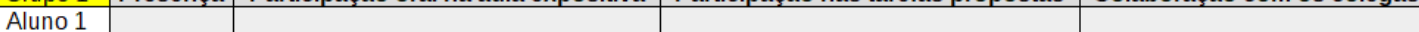 } \\
\hline \multicolumn{5}{|l|}{ Aluno 2} \\
\hline \multicolumn{5}{|l|}{ Aluno 3} \\
\hline \multicolumn{5}{|l|}{ Aluno 4} \\
\hline \multicolumn{5}{|l|}{ Aluno 5} \\
\hline \multicolumn{5}{|l|}{ Grupo 2} \\
\hline \multicolumn{5}{|l|}{ Aluno 1} \\
\hline \multicolumn{5}{|l|}{ Aluno 2} \\
\hline \multicolumn{5}{|l|}{ Aluno 3} \\
\hline \multicolumn{5}{|l|}{ Aluno 4} \\
\hline \multicolumn{5}{|l|}{ Aluno 5} \\
\hline \multicolumn{5}{|l|}{ Grupo 3} \\
\hline \multicolumn{5}{|l|}{ Aluno 1} \\
\hline \multicolumn{5}{|l|}{ Aluno 2} \\
\hline \multicolumn{5}{|l|}{ Aluno 3} \\
\hline \multicolumn{5}{|l|}{ Aluno 4} \\
\hline Aluno 5 & & & & \\
\hline
\end{tabular}

Primeiro, vamos apontar que, ao aplicar uma dinâmica gamificada em sala de aula, estimula-se que ela seja feita em grupos. Isso porque é uma forma de reforçar o caráter colaborativo da gamificação. E também porque facilitará na avaliação dos estudantes, como se apresenta na tabela acima. O fato de estarem participando da dinâmica em grupos ajuda na hora de elaborar um instrumento metodologicamente pensado para se fazer a observação ativa.

Nesta tabela, propomos a observação de quatro fatores: presença; participação oral na aula expositiva; participação nas tarefas propostas; colaboração com os colegas. O importante não são esses quatro fatores, que podem ser modificados e adaptados por cada professor. Importante é frisarmos que não é preciso que o estudante preencha todos os requisitos da tabela para ser constado que ele atingiu o padrão de qualidade desejado. Um aluno, por exemplo, pode ser tímido para participar da aula expositiva, mas ajudar o colega na tarefa. Ou mesmo, um aluno pode faltar à aula, mas realizar as tarefas propostas.

Tal instrumento dará para o professor dados, os quais, devem ser analisados de forma qualitativa e inteligente. É preciso tentar fugir 
da simples divisão matemática dos fatores a serem observados e entender que eles são apenas uma forma de coletar os dados da observação. A gestão dos dados, como dia LUCKESI (2018), é responsabilidade do professor e deve estar a serviço do objetivo da aprendizagem.

Os instrumentos avaliativos diversos que devem ser aplicados em sala de aula, numa dinâmica gamificada, estarão atrelados aos elementos motivadores dos jogos. Por exemplo: um trabalho realizado sobre determinado conteúdo, valerá para aquele grupo uma quantidade de moedas, que podem ser trocadas por conquistas, que Ihe atribuirão pontos e permitirão que o grupo avance na classificação geral. Ou seja, o próprio desempenho do grupo numa dinâmica gamificada (quantidade de pontos, de conquistas, de medalhas, ou qualquer coisa que o professor estabeleça para gamificar seu conteúdo) são mostras contínuas da qualidade do aprendizado desses estudantes.

Sendo assim, além de analisar os instrumentos diversos aplicados por si só, o professor poderá utilizar-se dos dados fornecidos pela própria dinâmica gamificada, para analisar se seus estudantes estão alcançando os objetivos de aprendizagem propostos.

Agora, precisamos repetir um ponto de suma importância dos nossos estudos: a metodologia aplicada deve estar em consonância com a avaliação. E por que repetimos isso? Porque, se se aplica uma dinâmica gamificada, nada mais contraditório, ao final desse processo, aplicar uma prova escrita tradicional. Tal prova não dialogará com a narrativa da gamificação, com seus elementos e emoções e será uma quebra brutal no andamento da dinâmica. Essa quebra pode ocasionar um fracasso na coleta de dados que a avaliação se pretende e ameaçar o próprio andamento da gamificação. 
Porém, a realidade é que, em muitas escolas a prova escrita não é opcional ao professor. É pré-requisito obrigatório. Por isso, proporemos, agora, uma forma de tentar driblar essa exigência. Temos a consciência de que nem toda escola isso será possível. No entanto, se atingirmos uma parte dos professores com essa proposta, já será de grande valia.

A proposta é a aplicação de uma prova escrita, múltipla escolha, porém, gamificada! Vejamos a seguir. Para construir a proposta de uma avaliação gamificada, é preciso se aprofundar, um pouco mais, em alguns elementos da gamificação. Como apontado anteriormente, Flora Alves (2015) apresenta um modelo elaborado por Keven Werbach que analisa o funcionamento dos jogos e como esses elementos se aplicam em uma dinâmica gamificada.

Assim, Alves descreve três partes importantes da gamificação: a dinâmica; a mecânica e os componentes (2015, p. 43). A dinâmica constrói um padrão regular para a experiência gamificada a partir de itens como: emoções; narrativa; progressão entre outros.

A prova gamificada que propusemos possui esses elementos. A avaliação é por questões objetivas, contendo cinco alternativas cada. O uso de questões de múltipla escolha tem dois propósitos: mostrar a possibilidade de fugir do tradicional, mesmo com esse tipo de questão, e facilitar a dinâmica de aplicação.

As questões estão dispostas em níveis progressivos de dificuldade e continham, necessariamente, um texto ou uma fonte a serem analisados. Esse elemento base não era, na questão, mera ilustração. A pergunta e as alternativas foram elaboradas de forma que os estudantes precisassem refletir cuidadosamente sobre determinado texto ou imagem. O uso de fontes históricas no ensino de História é parte essencial da construção de uma aprendizagem significativa. 
Percebam a presença do elemento de progressão, afinal, a cada nova questão aumentava o nível de dificuldade.

A emoção, por incrível que pareça, também está presente. Isso porque os grupos recebem uma questão por vez e, após a leitura, escolhem a resposta que julgam correta, chamando o professor para conferir. O grupo só recebe a questão seguinte, caso sua resposta esteja correta. Portanto, há uma emoção nela: a "conquista de uma nova questão".

Caso a resposta esteja errada, o grupo deve justificar o motivo, podendo pesquisar na internet para buscar a alternativa correta. Nesse processo, o professor contribui para que os estudantes entendam o erro da alternativa. Ainda que a busca na internet possa ajudar, para responder este formato de questão, o essencial ainda é analisar corretamente a fonte apresentada.

Tal processo foi repetido em todas as questões. Como em um jogo, as questões iam ficando mais difíceis, mas também os pontos atribuídos a elas eram maiores. Cada vez que o grupo precisasse refazer a questão, ele perderia uma quantidade pré-determinada de pontos. Caso acertasse na primeira tentativa, ganhava o valor cheio da questão.

Há também, entre os elementos da gamificação, a mecânica. Esta é responsável pela ação, movendo o processo adiante (ALVES, 2015 , p. 44). Fazem parte da mecânica, elementos como a cooperação e a competição, desafios, feedback, entre outros.

Estipula-se que a prova gamificada que seja aplicada em grupos. Essa opção relaciona-se com a ideia de reforçar os elementos colaborativos dos jogos no processo de gamificação. Nesse formato, também encontram-se os elementos da mecânica que se relacionam ao desafio, presente no próprio desafio de responder à questão. 
O feedback imediato se destaca como um dos pontos mais positivos desta proposta. Nas provas regulares tradicionais, dificilmente o professor consegue dar o retorno necessário da avaliação para o aluno. Assim, perde-se um pouco o objetivo da avaliação como parte do processo de ensino aprendizagem. Com o retorno imediato proporcionado pelo formato de jogo, os estudantes sabem, na hora, o que erraram e traçam novas estratégias para alcançar o objetivo e acertar a questão.

E, por fim, destacamos os componentes, que seriam "formas específicas de fazer o que a dinâmica e a mecânica representam", como avatares, boss fight, combate, entre outros (ALVES, 2015, p.45-46).

Na prova gamificada, outros elementos podem ser acrescentados pelo professor como, por exemplo, estimular que cada grupo crie seu avatar. Isso ajuda o aluno na sensação de imersão na prova-jogo. A última questão pode, também, ser pensada como uma questão diferente. Um desafio diferente das demais. Valendo mais pontos. Isso cria a sensação do "boss fight", ou seja, o chefão, um clássico entre os jogos eletrônicos.

\section{Considerações finais}

A avaliação é parte integrante do processo de ensino aprendizagem. Sem ela, não é possível elaborar e aplicar uma metodologia inovadora, capaz de transformar a realidade dos nossos estudantes, simplesmente porque não saberemos o quão eficaz foi essa metodologia. Tampouco adianta pensar em instrumentos novos, modernos e tecnológicos para avaliar o aprendizado, se a forma com que estamos ensinando continua presa a uma prática do século 
passado, que muito pouco tem a contribuir hoje em dia e está destinada a ser atropelada pela roda da história.

A atual geração, nascida e criada em uma sociedade densamente povoada pelas TICs, desenvolveu novas formas de relacionar-se com o conhecimento e interagir em sociedade. Em função disso, surge a necessidade de adequar a escola ao seu público atual, que busca formas mais dinâmicas e interativas de aprendizado.

A gamificação, nesse sentido, é uma proposta inovadora, capaz de despertar no estudante a vontade de aprender de forma ativa e autônoma, através da ludicidade proporcionada pelos elementos dos jogos. E para alcançarmos essa transformação, precisamos avaliar de uma forma que seja capaz de nos proporcionar dados suficientes para analisarmos se nossos objetivos estão sendo alcançados.

Neste artigo, apresentamos uma reflexão profunda deos debates relacionados à avaliação e à gamificação e propusemos formas de avaliar em uma dinâmica gamificada. Propusemos, também, uma alternativa para as realidades que insistem na necessidade de aplicar uma prova escrita ao final de um ciclo.

A prova gamificada incorpora uma série de elementos característicos dos jogos: níveis; estado de tensão e de vitória; possibilidade de tentar de novo; pontuação e trabalho em equipe, entre outros. O objetivo é ode quebrar o caráter opressivo característico desse tipo de exame, e avaliar em conformidade com os objetivos traçados por um ensino não tradicional de História.

Na preparação de uma dinâmica gamificada, esses itens irão dialogar entre si e serão capazes de produzir nos estudantes a sensação de fazer parte de um jogo, mesmo realizando tarefas comuns do cotidiano escolar. Espera-se que isto estimule o engajamento e a 
interação na busca de superar desafios e alcançar os objetivos propostos.

Os instrumentos avaliativos aqui propostos para uma dinâmica gamificada, sob o aspecto emocional, podem aliviar a tensão característica das avaliações (principalmente das provas escritas), dada a ambiência lúdica da dinâmica gamificada. Diante disso, esperase que eles se motivem e engajem, tanto no conteúdo, como no próprio instrumento avaliativo.

O formato da avaliação gamificada em grupo, experiência pouco usual para os estudantes, permite a valorização de cada um dos membros e explora habilidades como: colaboração; cooperação; pensamento reflexivo e empatia. Nesse novo ambiente dinâmico e acolhedor, a avaliação constituiu-se em um momento potente de busca de conhecimento, permitindo que a aprendizagem e a avaliação ocorram simultaneamente.

Um elemento relevante nesse processo é o feedback imediato, que permite ao estudante e ao grupo gerenciarem o seu processo de busca e recuperação de informações, reforçando o caráter ativo da aprendizagem no momento da avaliação. O feedback imediato também permite que os estudantes se mantenham motivados e engajados em todas as etapas da avaliação.

Portanto, gamificação em consonância com os instrumentos de avaliação corretos e adaptados podem ser uma forma de ensino inovadora, atendendo às demandas das novas gerações em relação à Escola. No entanto, ainda há muito que se caminhar, mas o caminho parece promissor. 


\section{REFERÊNCIAS}

ALVES, F.. Gamification: como criar experiências de aprendizagem engajadoras. São Paulo: DVS, 2015. BORGES, T. S.; ALENCAR, G.. Metodologias ativas na promoção da formação crítica do estudante: o uso das metodologias ativas como recurso didático na formação crítica do estudante do ensino superior. In: Cairu em Revista, Cairu, v. 3, n 4, p. 119-143, jul.-ago. 2014.

COSTA, E. V.. Os objetivos do ensino da História no Curso Secundário. In: Revista de História, jan.-mar. 1957.

GARDNER, H.. Inteligências Múltiplas: a teoria na prática. Porto Alegre: Artes Médicas, 1995.

GEMIGNANI, E. Y. M. Y.. Formação de Professores e Metodologias Ativas de Ensino-Aprendizagem. In: Revista Fronteira da Educação, Recife, v. 1, n. 2, 2012.

JÚNIOR, A. F. S.; SOUSA, J. J. M.. Ensino de História, relações étnico-raciais e estudos descoloniais. In: SEMANA DE HISTÓRIA DO PONTAL, 4., 2016, Ituiabata. Anais... Ituiabata: UFU, 2016. p. 1-11.

LAVILLE, C. A.. guerra das narrativas: debates e ilusões em torno do ensino de História. In: Revista Brasileira de História, São Paulo, v. 31, n. 60, p. 13-33, 1999.

LUCKESI, C. C.. O que é mesmo o ato de avaliar? In: Revista Pátio, Ano 3, n. 12, fev.-abr. 2000.

LUCKESI, C. C.. Avaliação em Educação: questões epistemológicas e práticas. São Paulo: Cortez Editora, 2018

MATTOS, I. R.. Mas não somente assim! Leitores, autores, aulas como texto e o ensino-aprendizagem de história. In: Tempo, Rio de Janeiro, v. 11, n. 21, p. 5-16, jul.-dez. 2006.

MORAN, J. M.; MASETTO, M.; BEHRENS, M.. Novas Tecnologias e Mediação Pedagógica. Campinas: Papirus, 2007.

NODA. M.. Avaliação e novas perspectivas de aprendizagem em História. In: Revista História \& Ensino: Londrina, v. 11, p. 143-151, 2005.

PRENSKY, M.. Nativos Digitais, Imigrantes Digitais. In: On the Horizon (NCB University Press), v. 9, n. 5, out. 2001.Trad. Roberta de Moraes Jesus de Souza. Disponível em: http://www.cp2.g12.br/moodle/mod/resource/view.php?id=4057. Acesso em: 19 jun. 2019

SCHIMIDT, M. A; CAINELLI, M. R.. Ensinar História: São Paulo: Scipione, 2004.

SCHLEMMER, E.. Gamificação em Espaços de Convivência Híbridos e Multimodais: Design e cognição em discussão. In: Revista da FAEEBA, Salvador, v. 23, n. 42, p. 73-89, jul./dez. 2014.

TRIVIÑOS, A. N. S.. Introdução à Pesquisa em Ciências Sociais: a pesquisa qualitativa em educação. São Paulo: Atlas, 1987

ZICHERMANN, G. e CUNNINGHAM, C.. Gamification by Design. Sebastopol: O Relly, 2011 